\title{
Constraints on pre-eruptive magmatic history using multi- faceted diffusion modeling: an analytical, experimental and numerical study
}

\author{
Dissertation \\ zur Erlangung des mathematisch-naturwissenschaftlichen Doktorgrades \\ "Doctor rerum naturalium" \\ der Georg-August-Universität Göttingen \\ im Promotionsprogramm Geowissenschaften / Geographie \\ der Georg-August University School of Science (GAUSS) \\ vorgelegt von \\ Smruti Sourav Rout \\ aus Dhenkanal, Indien
}

Göttingen 2019 


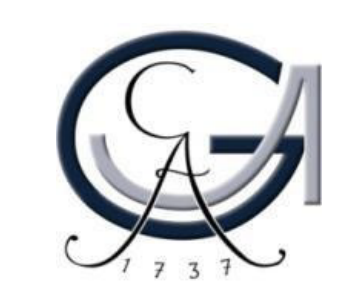

Thesis advisory committee:

Supervisor:

Prof. Dr. Gerhard Wörner (Dep. Geochemistry, GZG)

Co-supervisor:

Prof. Dr. Sharon Webb (Dep. Experimental and Applied Mineralogy, GZG)

\section{Examination committee:}

Prof. Dr. Gerhard Wörner (Dep. Geochemistry, GZG)

Prof. Dr. Sharon Webb (Dep. Experimental and Applied Mineralogy, GZG)

Prof. Dr. Andreas Pack (Dep. Isotope Geology, GZG)

Prof. Dr. Francois Holtz (Institut für Mineralogie, Leibniz Universität Hannover)

Dr. Burkhard Schmidt (Dep. Experimental and Applied Mineralogy, GZG)

Dr. Andreas Kronz (Dep. Geochemistry, GZG)

\section{Day of defense:}

22.01.2020 


\section{ABSTRACT}

Time-scales extracted from chemically zoned minerals provide insights into crystal residence time, magma storage and compositional evolution of magmas and allow better constraints on pre-eruptive history of large and potentially dangerous magma chambers. We applied diffusion chronometry to different eruption products from Laacher See volcano (Germany) and Taapaca volcano (Chile).

(a) Laacher See volcano: (1) Diffusion modeling of Ba-diffusion across outermost resorption interfaces in sanidine phenocrysts constrains the time between magma mixing and eruption to be 4-8 years. Diffusion time-scales obtained from interior resorption and regrowth zones suggest a recharge frequency of every $1.5-3 \mathrm{ky}$ in the past $\sim 24 \mathrm{ky}$ history of the mama reservoir. (2) Carbonatitic syenites are interpreted to represent a crystallizing carapace around the phonolite magma. The pre-eruptive, core-rim Na-K diffusion in sanidines constrains the effective storage temperature at $630-670{ }^{\circ} \mathrm{C}$. These values along with a conduction model constrain the radial inward growth rate of the syenite carapace at $\sim 8 \mathrm{~cm} /$ year. Uphill diffusion modeling across exsolution boundaries in sanidine gave a maximum time between the destabilisation of the carapace and eruption of only 40-50 days. (3) Crystal mushes that form accumulation of phenocrysts are generally devoid of zoned crystals. Only crystals with resorbed boundaries or very thin overgrowths (a few microns) with very sharp compositional changes imply the activation of cumulates only months before eruption.

(b) Taapaca volcano: Sanidine megacrysts in dacites show repetitive, sharp jumps in $\mathrm{Ba}$ concentration at resorption interfaces that reflect frequent heating events during their growth. These distinct growth bands formed at temperatures of $\sim 720$ to $820{ }^{\circ} \mathrm{C}$ pressures of 1 3 kbar based on amphibole-plagioclase thermometry and Al-in-Hornblende barometry for each growth zone separately. A non-isothermal diffusion modeling was tested experimentally using halogen diffusion and further developed in terms of precision. The new algorithm was applied to Ba-profiles across individual diffusive boundaries to give diffusion times ranging from 0.4 to $490 \mathrm{ky}$ and total residence times of 9 to $499 \mathrm{ky}$ for different crystals from different stages of eruption. All crystals show late oscillatory overgrowths that indicate multiple heating events in the magmatic system at increased frequency only $\sim 0.4$ to $3 \mathrm{ky}$ before eruption.

Based on these diffusion times and storage temperatures, genetic models for the process and timing of storage and activation are presented for both the magma systems with respect to the current discussions regarding cold- versus hot-storage models. 
1.1. Introduction

1.2. Scope and structure of the thesis

1.3. Studied volcanic area

1.3.1. Laacher See volcano 6

$\begin{array}{ll}\text { 1.3.2. Taapaca volcano } & 7\end{array}$

1.4. Research activity

1.5. Author contributions $\quad 10$

1.6. References 12

Chapter 2. Zoning and exsolution in alkali feldspars from Laacher See volcano (Western Germany): constraints on temperature history

prior to eruption

Abstract

2.1. Introduction 17

2.2. Geology and petrography 19

2.2.1. Geological setting $\quad 19$

2.2.2. The Laacher See eruption 20

2.2.3. Samples and petrography $\quad 23$

2.3. Analytical methods 27

2.4. Results and discussion $\quad 29$

2.4.1. Constraints on parameters used in diffusion $\quad 34$ modeling

2.4.2. Diffusion modeling $\quad 38$

2.4.3. A residence history model: cold versus hot crystal $\quad 42$ mush

2.4.4. Relations between liquid core and crystal-rich $\quad 45$ carapace and cumulates

2.5. Conclusion 49

2.6. References 50

Chapter 3. Constraints on the pre-eruptive magmatic history of 57

$\begin{array}{cc}\text { Laacher See volcano (Germany): study of different eruption products } & 57 \\ \text { Abstract } & 57\end{array}$

3.1. Introduction $\quad 58$

$\begin{array}{ll}3.2 . & 60 o l o g y \\ \text { and petrography } & 60\end{array}$

3.2.1. Geological setting $\quad 60$

3.2.1. The Laacher See eruption $\quad 62$

$\begin{array}{ll}\text { 3.2.2. Sample and petrography } & 64\end{array}$

$\begin{array}{ll}\text { 3.3. Analytical methods } & 69\end{array}$

$\begin{array}{ll}\text { 3.4. Results and discussion } & 70\end{array}$

$\begin{array}{ll}\text { 3.4.1. The zonation (texture, causes and comparison } & 70\end{array}$ between samples)

3.4.2. How to extract crystal residence times through 75 Ba-diffusion modeling?

3.4.3. A model for storage history prior to eruption $\quad 80$

3.5. Conclusion and summary $\quad 84$ 
3.6. References

Chapter 4. Constraints on non-isothermal diffusion modeling: an experimental analysis and error assessment using halogen diffusion in

melts

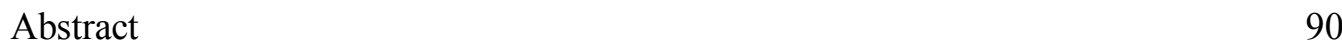

4.1. Introduction 91

4.1.1. Non-isothermal diffusive analysis and the NIDIS 93 model

4.1.2. Alternative curve parameter method 95

4.2. Experimental and analytical methods $\quad 97$

4.2.1. Starting material 97

4.2.2. Experiments 99

4.3. Analytical techniques 100

4.4. Results and discussion 102

$\begin{array}{ll}\text { 4.5. Implications } & 117\end{array}$

$\begin{array}{ll}\text { 4.6. References } & 118\end{array}$

$\begin{array}{ll}\text { 4.7. Appendix } & 122\end{array}$

Chapter 5. Pre-eruptive history of Taapaca volcano (N. Chile)

constrained by non-isothermal diffusion chronometry on sanidine 123

megacrysts

$\begin{array}{lr}\text { Abstract } & 123\end{array}$

$\begin{array}{ll}\text { 5.1. Introduction } & 124\end{array}$

5.2. Geology and petrography 126

5.2.1. Geological setting 126

5.2.2. History and compositions of lavas erupted at 128

Taapaca volcano

5.2.3. Sample and petrography 130

5.3. Methods 132

5.3.1. Analytical methods $\quad 132$

5.3.2. Thermo-barometry 133

5.3.3. Rhyolite-MELTS modeling 135

$\begin{array}{ll}\text { 5.4. Results and discussion } & 137\end{array}$

5.4.1. Patterns and Style of compositional zonation in 137 Taapaca sanidine megacrysts

5.4.2. Ba-diffusion modeling 148

5.4.3. Storage history prior to eruption 156

5.4.4. What triggered the eruption? 159

$\begin{array}{ll}\text { 5.5. Summary and conclusion } & 160\end{array}$

5.6. References 161

$\begin{array}{lr}\text { Chapter 6. Conclusion } & 169\end{array}$

$\begin{array}{ll}\text { 6.1. Introduction } & 169\end{array}$

$\begin{array}{ll}\text { 6.2. Summary of findings and conclusion } & 170\end{array}$

$\begin{array}{ll}\text { 6.3. Outlook } & 173\end{array}$

$\begin{array}{ll}\text { 6.4. References } & 174\end{array}$

$\begin{array}{ll}\text { Appendix A } & 177\end{array}$

$\begin{array}{ll}\text { Appendix B } & 179\end{array}$

$\begin{array}{ll}\text { Appendix C } & 180\end{array}$ 


\section{Preface}

This dissertation presents the work done as a doctoral project at the Department of Geochemistry together with collaboration with Department of Experimental and Applied Mineralogy at Gerog-August-Universität Göttingen (Göttingen, Germany). The project was possible because of the doctoral fellowship (fellowship ID: 57129429, reference number: 91564958) from Deutscher Akademischer Austauschdienst (DAAD) to S. S. Rout, the PhD student. The work plan was principally framed by the PhD student and Prof. Dr. Gerhard Wörner with prominent help from Dr. Burkhard Schmidt. The project started in October, 2015 after the arrival of S. S. Rout in Germany and took four years to complete. The initial timeframe was set for three years. However, due to unexpected additional analytical work, publication writing and the extension of the research inspired by the immediate findings led to extension of the time frame by one more year. At the end of the four years, the planned work has been managed to completion and the study has led to preparation of four manuscripts (one published, one accepted and in press and two to be submitted).

\section{Keywords}

Diffusion modeling, Chronometry, Laacher See; Taapaca volcano; Zoned sanidine phenocrysts; Non-isothermal diffusion; Carbonatitic-syenite; Magma storage; EPMA 


\section{Acknowledgements:}

There are a lot of people I need to thank who have contributed to my $\mathrm{PhD}$ or to my experience during the $\mathrm{PhD}$ in every small or big way. First of all, I would like to thank DAAD for the doctoral fellowship and for approving all the extensions we required to complete the planned study.

I can never be able to thank my supervisor Prof. Dr. Gerhard Wörner enough, who has guided me in every possible way at every possible step towards achieving the research goals. His support, encouragement and patience are among the major reasons behind the completion of the planned project. His knowledge and research aptitude have continuously inspired me to learn more and grow at both technical and professional level.

I also thank Dr. Burkhard Schmidt, who trained me in experimental work and was very patient and helpful during the experimental work, especially during the initial days. I thank him for all the support and guidance. I thank Prof. Dr. Sharon Webb for always being ready to help, when needed and for writing numerous reference letters to DAAD. I thank Dr. Andreas Kronz for the training and support during the microprobe analyses, which constitute the backbone of this project.

I thank my previous colleagues Dr. Raffaella S. Iovine, Dr. Shitou Wu, Dr. Mika Kohno and Paul Heckmann for the friendship, for their much-needed help during research and for their company which made my days at work much more enjoyable. I specially thank Raffaella for her constant support since the very first day (even until now), and for being the first person I contact in case of any doubt or confusion. I thank Dr. Sara Fanara, Dr. Stefan Peters and Dr. Sukanya Sengupta for the all the help and encouragement. I thank Caren, Dr. Klaus Simon and everyone in the geochemistry, and experimental and applied mineralogy departments for all the helpful discussions.

I also thank all my friends for making the stressful time of $\mathrm{PhD}$ a tad bit easier. I thank my parents, especially my mother for always encouraging me towards higher education and hard work. I thank my maternal grand-parents and the entire family for their love and support. Lastly, I am delighted to thank my partner Dennis Waltz, who supported me with patience and great understanding in every small and big way in the past 2 years.

My sincere gratitude to everyone, also to those whose names I may have forgotten to mention. I also thank the city of Göttingen, for making the past four years one of the most wonderful and memorable periods of my life. 


\section{Chapter 1: Introduction}

\subsection{Introduction:}

Understanding the innerworkings of shallow crustal-level magma systems is one of the key research objectives in geoscience. These shallow magma systems, especially the silicic ones, control not only the growth and evolution of continental crust (Keller et al. 2015), but also the size and frequency of explosive and hazardous volcanic eruptions (Gelman et al. 2013, Lipman and Bachmann 2015, Cashman et al. 2017 and many others). They have produced many of the largest and most explosive eruptions on this planet, generating more than hundreds to thousands of $\mathrm{km}^{3}$ of magma e.g. Fish Canyon Tuff (28 Ma, $>5000 \mathrm{~km}^{3}$ ), Toba (74 ka, $\sim 2800 \mathrm{~km}^{3}$ ), Huckleberry Ridge Tuff (2 Ma, $\sim 2500 \mathrm{~km}^{3}$ ), Blacktail Tuff (6 Ma, 1500 $\left.\mathrm{km}^{3}\right)$ and Oruanui $\left(26.5 \mathrm{ka}, \sim 530 \mathrm{~km}^{3}\right)$ (Bachman et al. 2002; Storey et al. 2012; Best et al. 2013; Morgan and McIntosh 2005; Wilson 2001). Besides devastating threat to life and infrastructure, large silicic eruptions are also likely to have adverse impacts on atmosphere, global temperature and climate (Self and Blake 2008; Robock et al. 2009; Sigl et al. 2015). This makes these explosive silicic eruptions one of the most dangerous natural hazards in terms severity and longevity of the impacts (Self and Blake 2008; Miller and Wark 2008). Despite the level of threat, the processes inside large silicic magma reservoirs that control their evolution and drive them towards eruption are either largely unknown or poorly constrained (Reid 2008, Bachman and Huber 2019). Moreover, no such gigantic eruption has been observed recently to allow better understanding using the modern-day real-time monitoring technology. This makes the study of evolution of such large silicic systems more of a challenge. And studying past eruption products using geochemical methods has been developed in the past few decades as an efficient approach to address this challenge.

One of the state-of-the-art methodologies used in geochemistry to constrain the pre-eruptive magmatic history, especially with respect to time, is diffusion modeling. The basic concept behind diffusion modeling is that when crystals experience changes in the surrounding magmatic environments, they undergo several stages of crystallization each one resulting in a compositionally different zone. This compositional contrast between adjacent zones leads to disequilibrium which is then equilibrated by diffusive mass transfer or chemical diffusion. The rate at which this diffusive equilibration functions depends on intensive parameters like 
temperature (Costa et al. 2008). Thus, with the knowledge of the ambient temperature, rates of diffusion (diffusivity) can be calculated and the duration of this chemical equilibration can be constrained (Costa et al. 2008, Dohmen et al. 2017). In this study, we explored different aspects of diffusion modeling in order to constrain pre-eruptive magmatic history. We studied the pre-eruptive "state of a reservoir" and the processes that maintain and/or change this state along the reservoir's way towards eruption. In this attempt to apply and, wherever required, improve, the multi-faceted use of diffusion modeling, we studied different eruption products from Laacher See volcano (Germany) and Taapaca volcano (Chile). The studies were aimed at constraining the duration and condition of magma storage, frequency of recharge events, and the timing and nature of the processes that prompted the eruption at these two volcanoes.

\subsection{Scope and structure of the thesis:}

This main body of the dissertation, that comprises of methods, results and detailed discussion, comprises of four chapters (chapters 2-5) each of which is either a published/submitted/prepared manuscript. One of the concerned manuscripts is already published, one is currently in pre-production processing after acceptance and two are prepared to be submitted. In order to achieve the desired goals, four primary lines of investigation i.e. (1) bulk and mineral chemistry (2) thermo-barometry, (3) multi-element diffusion modeling, and (4) analytical and numerical modeling are employed. To obtain the required geochemical data, several analytical and micro-analytical methodologies were adopted.

In chapter 2, the study of carbonatitic-syenites, one of the unique eruption products from Laacher See volcano, is presented. In this study, we use petrographic observations, trace element data and diffusion modeling in the crystal-rich syenites from Laacher See volcano to constrain the sequence and time-scale of pre-eruptive events. Samples with existing U-series ages were studied which allowed to invert the diffusion modeling to extract information on storage temperatures and for the first time, put constraints on storage temperature of crystals from this (or any) magmatic system. A relatively uncommon uphill diffusion was also applied to exsolution in $\mathrm{K}$-feldspars which contributed towards constraining the long and immediate pre-eruptive history of the volcano.

In chapter 3 , the study of phonolites and phonolitic cumulates, the two other major types eruption products from Laacher See volcano, is presented. In this study, we use petrographic observations, existing experimental data and usual diffusion chronometry on zoned k- 
feldspars to constrain the thermal history of the entire reservoir, recharge frequency and timing of the eruption-triggering recharge for the Laacher See volcano.

In chapter 4, the experimental analysis of the "Non-Isothermal Diffusion Incremental Step (NIDIS)" model proposed by Petrone et al. 2016 (Nat. Commun. 7, 12946), error assessment and our own modifications to the model are presented. The NIDIS model is an essential tool that can be used to model non-isothermal diffusion (as opposed to the classical isothermal diffusion model) ensuring more robust temporal constraints. The efficiency of this model was tested by a series of halogen diffusion experiments and an alternative simpler set of steps was proposed to minimize the errors in the model. A natural sample was also used to show the advantage of the model and of our alternative algorithm. The associated range and propagation of errors (e.g. uncertainty in temperature, curve fitting, diffusivity parameters) were also studied.

In chapter 5, I present an extensive use of the above non-isothermal diffusion modeling to the eruption products from Taapaca volcano (Chile). In this study, we use petrographic observations, thermo-barometry, non-isothermal diffusion modeling on zoned sanidine megacrysts and R-MELTS modeling to constrain the thermal history, recharge frequency and pre-eruptive remobilization of the reservoir beneath Taapaca volcano. The numerous mineral inclusions in the mgacrysts allow high-reolution constraints on the thermal history which then allow robust temporal constraints using the non-isothermal diffusion modeling.

In terms of methodology, the above four chapters deal with different aspects of diffusion modeling. Chapter 2 applies diffusion modeling to constrain temperature using known time, while chapter 3, 4 and 5 apply diffusion modeling to constrain time using known temperature. Chapter 2 and 3 use isothermal diffusion modeling while chapter 4 and 5 focus on the nonisothermal nature of diffusion.

The overall conclusions and outlook are presented in the last chapter i.e. chapter 6 .

All major data, results and conclusions from the project are in the four manuscripts. The methods, detailed discussions and conclusions specific to each line of work are presented in the respective chapter. 


\subsection{Studied volcanic area:}

\subsubsection{Laacher See volcano:}

The Laacher See $(12.9 \mathrm{ka})$ is a phonolitic volcano in the west of Germany. It produced the largest and and the most recent eruption in the Quaternary East Eifel Volcanic Field (EEVF). It is part of the intra-plate alkaline volcanism in central Europe and is in the western part of the uplifted Paleozoic Rhenish Massif (Schmincke 2007, 2008).

As part of the Upper Tertiary to Quaternary magmatism in EEVF, the small scattered yet clustered eruption centers as well as large shield volcanoes (e.g. Vogelsberg, 15-16 ka) produced a variety of mafic magmas ranging from basanitic and alkali basaltic to quartz tholeiitic compositions (Wilson and Downes 1991; Wedepohl and Baumann 1999; Bogaard and Wörner 2003). The eruption centers in the EEVF produced basanitic, nephelinitic and leucititic magmas as well as their differentiated products over the past $\sim 40 \mathrm{ky}$ (Duda and Schmincke 1978; Wörner and Schmincke 1984a; Bogaard et al. 1989a, b; Bogaard and Schmincke 1990; Schmincke 2007). These mafic eruptions at the beginning were phreatomagmatic eruptions, along with blocky lava flows and maars, which formed several scoria cones (Schmincke et al. 1973; Schmincke 2007). The most primitive ash deposits date back to 450-650 ka (Bogaard and Schmincke 1990) erupted in the North West right before evolved volcanism began in EEVF.

Rieden volcanic complex produced the first evolved magmas in EEVF. It produced phonolite and leucitititc tephra deposits of more than $10 \mathrm{~km}^{3}$ of volume $380-430 \mathrm{ka}$ (Viereck 1984; Bogaard et al. 1989a; Bogaard and Schmincke 1990). After Rieden, Wehr volcano was the next which produced phonolitic to trachytic tephra deposits $\sim 215 \mathrm{ka}$ and evolved phonolitic tephra depsosits 150 ka (Wörner et al. 1988; Bogaard and Schmincke 1990). The third evolved volcanic center is the phonolitic Laacher See, which is the largest among the three. The phonolite of Laacher See, which fed the gigantic eruption $12.916 \mathrm{ka}$ (Baales et al. 2002), is the product of $\sim 20 \mathrm{ky}$ long evolution (Schmitt et al., 2010).

On the whole, the eruption history of EEVF consists of mostly varieties of mantle-derived alkaline magmas with eruption of some evolved magmas in between. The evolved magmas are identified to be the differentiated products of the very mafic magams (Duda and 
Schmincke 1978, Viereck 1984 and Wörner and Schmincke 1984a, b). Advanced crustal assimilation is seen only in the trachytes from the Wehr volcano (Wörner et al. 1988).

\subsubsection{Taapaca volcano:}

The Andean Quaternary volcanism is divided into four sections, the Northern, Central, Southern and Austral volcanic zones, separated by volcanic gaps (Thorpe et al. 1982). Taapaca Volcanic Complex (TVC) or Nevados de Putre $\left(5824 \mathrm{~m}, 18{ }^{\circ} \mathrm{S}, 69^{\circ} \mathrm{W}\right)$ is situated in the Central Volcanic Zone (between latitudes $14^{\circ}$ and $28^{\circ} \mathrm{S}$ ) where Nazca plate subducts beneath the South American plate.

The TVC belongs to the Western Cordillera, which constitutes the NW-SE Quaternary volcanic chain at the border between Chile and Bolivia and lies to the west of the largest noncollisional orogenic plateau on the planet, the Altiplano Plateau (Isacks 1988). This region has numerous active volcanoes with height of $6 \mathrm{~km}$ asl. Taapaca volcano is slightly atypical as it lies about $30 \mathrm{~km}$ to the west of the main volcanic chain that is located at the centre of the CVZ.

Around $180 \mathrm{Ma}$, the 'modern' cycle of active continental margin magmatism began in the Central Andes. In the Coastal Cordillera at the current coastal area, Jurassic intrusive and extrusive igneous arc rocks are exposed. The focus of the volcanism migrated between Jurassic and Miocene from the coastal Cordillera in the west to the Altiplano region in the east (e.g. Scheuber et al. 1994). The currently active volcanic front is situated at the western margin of Altiplano. Reasons behind the arc migration are unclear and debated. Massive tectonic erosion in the forearc and shallowing of the subduction angle could be a reason. Presently, the subducting slab sinks at a relatively shallow angle of $\sim 25$ to $30^{\circ}$ (Cahill and Isacks 1992) at a convergence rate of $7.5-8 \mathrm{~cm} /$ year (Samoza 1998). The volcanic chain of CVZ lies around 120-150 km above the subducted slab with exceptionally thick continental crust $(>70 \mathrm{~km}$ ) in between (James 1971; Zandt et al. 1994; Allmendinger et al. 1997; Scheuber and Giese 1999; Yuan et al. 2002; Tassara et al. 2006).

The continental crust below the Altiplano region consists of Palaeoproterozoic (2.0-1.8 Ga) Arequipa terrane denoted by metamorphic and igneous rocks exposed in southern Peru and in a series of inliers in N Chile and W Bolivia (Loewy et al. 2004; McLeod et al. 2013). 
Proterozoic amphibolites and gneisses of metamorphic Belen Complex are exposed in northernmost Chile along the Chilean Precordillera just $35 \mathrm{~km}$ to the south of Taapaca, and granulites and charnockites of Cerro Uyarani on the western Altiplano are equivalents to the basement rocks underlying the CVZ in northern Chile (Wörner et al. 2000).

The TVC has a long eruption history that began at more than 1.5 My BP (Clavero et al. 2004). The volcanic edifice of Taapaca lies partly on a heavily eroded topography on the western margin of the Cordillera and consists of clusters of elongated domes with three exposed summit domes. The highest dome is about $5850 \mathrm{~m}$ high asl. The volume of the main edifice is estimated at $35 \mathrm{~km}^{3}$ and the erupted products from TVC cover an area of $\sim 250 \mathrm{~km}^{2}$ (Clavero et al. 2004). The volcano is directly underlain by the 2.7 My old Lauca ignimbrite (Wörner et al. 2000), Miocene andesitic lava flows, and the Upper Oligocene to Lower Miocene Lupica Formation. TVC has undergone frequent edifice collapse events documented by numerous debris avalanche deposits.

\subsection{Research activity:}

This study provides a multidisciplinary approach that combines various geochemical and analytical methods used in volcanic geochemistry. The major lines of investigation are discussed below.

(1) In terms of analytical methods, the primarily used facilities are Electron microprobe (EMP) and Laser ablation inductively coupled mass spectrometer (LA-ICPMS). Several analytical methods e.g. line analysis, map analysis, image analysis and x-ray scanning are utilized to obtain high resolution compositional data. Although the maps and compositional data were obtained on many minerals for the purpose of petrography and thermometry, profiles were obtained majorly in K-feldspars and in experimental glasses. Other than that, Raman spectroscopy and Fourier transform infrared (FTIR) spectrometer to test and measure volatile content in melt inclusions and experimental glasses.

(2) Double diffusive experiments are performed to test the non-isothermal diffusion model before applying it to natural samples. The experiments are designed at preset conditions to develop multiple diffusion boundaries that are equivalent to successive 
compositional zonation. Glasses of phonolitic composition with robust constraints on diffusivities were prepared at the beginning of the study. After the experiments, the recovered samples were analyzed with EMP to obtain compositional gradients to use in the model. After verification various error assessment studies were done on the model and the original algorithm was simplified to give a simpler yet more precise set of steps.

(3) For diffusion modeling, k-feldspars in (1) the three major petrographic and compositional types of eruption products from Laacher See: the carbonatitic syenite, phonolitic pumice and phonolitic cumulates, (2) the dacite samples from Taapaca volcano were analyzed. In the case of Laacher See, uphill and forward diffusion (K$\mathrm{Na}$ interdiffusion) modeling was applied to the syenites, and only forward diffusion (Ba) was applied to the pumice and cumulate samples. This was the first study to conduct diffusion modeling in the case of Laacher See. In the case of Taapaca volcano, non-isothermal diffusion $(\mathrm{Ba})$ analysis was applied and it is one the most extensive application of the model to natural samples, and the first one in case of Taapaca.

(4) To constrain intensive parameters (temperature, pressure, $\mathrm{fO}_{2}$ ), primarily mineral phase equilibria based thermo-oxybarometry, existing experimental data and RMELTS modeling are used. Diffusion modeling is also used in case of syenites to obtain storage temperature using radiometric ages.

Other than these major lines of investigation, numerical modeling is also used e.g. to constrain physical evolution of parts of the reservoir (chapter 2). 


\subsection{Author contributions:}

Three other researchers, including my principal supervisor have contributed in the performed and presented research. The results of the $\mathrm{PhD}$ program have been and are being partially published in two articles in reputed international scientific journals with high impact factor. Other results produced during the $\mathrm{PhD}$ program have not yet been published, but are currently submitted or will soon be submitted (see Appendix B). Together the two scientific published/in-press papers and the two other prepared works constitute the methods, results and discussion parts of the thesis. The affiliation and exact contributions of all the authors are reported below.

\section{Chapter 2. Zoning and exsolution in alkali feldspars from Laacher See volcano (Western} Germany): constraints on temperature history prior to eruption

Smruti Sourav Rout a, Gerhard Wörner ${ }^{\text {a }}$

a Geowissenschaftliches Zentrum, Georg-August-Universität, Göttingen, Germany

This chapter was published in Contributions to Mineralogy and Petrology in October, 2018.

In this manuscript, my contribution as first author is that I executed all the analytical work, diffusion modeling, preparation of figures and tables, the writing the first draft, joint interpretation and joint writing of the final version of the manuscript.

Prof. Dr. Gerhard Wörner, who is the coauthor and also the $\mathrm{PhD}$ supervisor, has jointly written the final version of the manuscript, and has jointly developed the interpretation and discussion of the results.

Chapter 3. Constraints on the pre-eruptive magmatic history of Laacher See volcano (Germany): study of different eruption products

Smruti Sourav Rout ${ }^{\text {a }}$, Gerhard Wörner ${ }^{\text {a }}$

a Geowissenschaftliches Zentrum, Georg-August-Universität, Göttingen, Germany

This chapter, to this date, has not been submitted for publication. 
In this manuscript, my contribution as first author is that I executed all the analytical work (few compo-maps were already available from a previous $\mathrm{PhD}$ thesis of $\mathrm{C}$. Ginibre, see text for details), diffusion modeling, preparation of figures and tables, interpretation and the writing the current draft of the manuscript.

Prof. Dr. Gerhard Wörner, who is the coauthor and also the PhD supervisor, has provided minor inputs towards the interpretation and discussion of the results, but has not reviewed it yet.

Chapter 4. Constraints on non-isothermal diffusion modeling: an experimental analysis and error assessment using halogen diffusion in melts

Smruti Sourav Rout ${ }^{\text {a }}$, Burkhard C. Schmidt ${ }^{\text {a }}$, Gerhard Wörner ${ }^{\text {a }}$

a Geowissenschaftliches Zentrum, Georg-August-Universität, Göttingen, Germany

This chapter has been accepted for publication in September 2019 and is in press.

In this manuscript, my contribution as first author is that I executed all the experimental work, analytical work, diffusion modeling, error assessment, development of the alternate algorithm, making figures and tables, application of the model to natural samples and writing the first version and jointly writing the final version of the manuscript.

Dr. Burkhard C. Schmidt, who is the second author, contributed towards planning the experiments, supervised and helped in the sample preparation and experimental work, and edited and jointly wrote the final version of the manuscript.

Prof. Dr. Gerhard Wörner, who is the coauthor and also the PhD supervisor, has contributed towards the editing and improving the manuscript.

Chapter 5. Pre-eruptive history of Taapaca volcano (N. Chile) constrained by nonisothermal diffusion chronometry on sanidine megacrysts.

Smruti Sourav Rout ${ }^{\text {a }}$, Magdalena Blum-Oeste ${ }^{\mathrm{a}^{*}}$, Gerhard Wörner ${ }^{\text {a }}$

a Geowissenschaftliches Zentrum, Georg-August-Universität, Göttingen, Germany 
a* Previously at Geowissenschaftliches Zentrum, Georg-August-Universität, Göttingen, Germany

This chapter has not been submitted for publication to this date.

In this manuscript, my contribution as first author is that I executed the EMP analytical work for 8 out of 24 samples, R-MELTS modeling, diffusion modeling and thermo-barometry for all the samples, preparation of the figures and tables, interpretation of the results and the writing the first version and jointly writing the current version of the manuscript.

Dr. Magdalena Blum-Oeste, who is the second author, executed the sample preparation for all the 24 samples, EMP analysis of 16 out of 24 samples, and LA-ICPMS analysis of a few of the samples used in this study during her dissertation work.

Prof. Dr. Gerhard Wörner, who is the coauthor and also the PhD supervisor, has contributed significantly towards preparing and editing some of the maps and figures, and jointly writing the current version of the manuscript, especially the "Results and discussion" and "Summary and conclusion" sections.

\subsection{References:}

Allmendinger RW, Jordan TE, Kay SM, Isacks B (1997) The evolution of the Altiplano-Puna plateau of the Central Andes. Annual Reviews of Earth and Planetary Sciences 25:139-174.

Baales M, Jöris O, Street M et al (2002) Impact of the late glacial eruption of the Laacher See volcano, Central Rhineland, Germany. Quaternary Research 58:273-288.

Bachmann O, Dungan MA, Lipman PW (2002) The Fish Canyon magma body, San Juan volcanic field, Colorado: rejuvenation and eruption of an upper-crustal batholith. Journal of Petrology 43:1469-1503

Bachmann O, Huber C (2019) The inner workings of crustal distillation columns: The physical mechanisms and rates controlling phase separation in silicic magma reservoirs: Journal of Petrology 60:3-18. https:// doi .org /10 .1093/petrology /egy103

Best MG, Christiansen EH, Deino AL, Gromme S, Hart GL, Tingey DG (2013) The 36-18 Ma Indian Peak- Caliente ignimbrite field and calderas, southeastern Great Basin, USA: Multicyclic super-eruptions. Geosphere 9(4):864-950

Bogaard PJF, Wörner G (2003) Petrogenesis of basanitic to tholeiitic volcanic rocks from the Miocene Vogelsberg, Central Germany. J Petrol 44:569-602. 
Bogaard vdC, Bogaard vdP, Schmincke HU (1989a) Quartärgeologisch-tephrostratigraphische Neuaufnahme und Interpretation des Pleistozänprofils Kärlich. Eiszeitalter und Gegenwart 39:62-86.

Bogaard vdP, Hall CM, Schmincke HU, York D (1989b) Precise single-grain 40Ar/39Ar dating of a cold to warm climate transition in Central Europe. Nature 342:523-525.

Bogaard vdP, Schmincke HU (1990) Vulkanologische Karte der Osteifel (Maßtab 1:50000). Karlsruhe.

Cashman KV, Sparks RSJ, Blundy, JD (2017) Vertically extensive and unstable magmatic systems: A unified view of igneous processes: Science, v. 355, eaag3055

Cahill T, Isacks BL (1992) Seismicity and shape of the subducted Nazca plate. Journal of Geophysical Research Letters 97:17503-17529.

Clavero JE, Sparks RSJ, Pringle MS, Polanco E, Gardeweg MC (2004) Evolution and volcanic hazards of Taapaca Volcanic Complex, central Andes of northern Chile. Journal of Geological Society 161, 603-618.

Costa F, Dohmen R, Chakraborty S (2008) Timescales of magmatic processes from modeling the zoning patterns of crystals. In: Putirka KD, Tepley III FJ (eds) Minerals, Inclusions and Volcanic Processes. RiMG 69, Mineralogical Society of America, Chantilly, VA, USA, pp $545-594$

Dohmen R, Faak K, Blundy JD (2017) Chronometry and speedometry of magmatic processes using chemical diffusion in olivine, plagioclase and pyroxenes. Rev. Mineral. Geochem 83:535-575, https://doi.org/10.2138/rmg.2017.83.16

Duda A, Schmincke HU (1978) Quaternary basanites, melilitite nephelinites and tephrites from the Laacher See Area, Germany. Neues Jahrbuch für Mineralogie-Abhandlungen 132:1-33

Gelman SE, Gutierrez FJ, Bachmann O (2013) On the longevity of large upper crustal silicic magma reservoirs. Geology 41:759-762

Isacks BL (1988) Uplift of the Central Andean plateau and bending of the Bolivian orocline. Journal of Geophysical Research 93 (B4) 3211 - 3231.

James DE (1971). Andean crustal and upper mantle structure. Journal of Geophysical Research 76:3246-3271.

Keller CB, Schoene B, Barboni M, Samperton KM, Husson JM (2015) Volcanic-plutonic parity and the differentiation of the continental crust: Naturec523:301-307.

Lipman PW, Bachmann O (2015) Ignimbrites to batholiths: Integrating perspectives from geological, geophysical, and geochronological data: Geosphere 11:705-743

Loewy SL, Connelly JN, Dalziel IWD (2004) An Orphaned Basement Block: The Arequipa- Antofalla Basement of the Central Andean margin of South America. Geological Society of America Bulletin 116:171-187. 
McLeod CL, Davidson JP, Nowell GM, de Silva SL, Schmitt AK (2013) Characterizing the continental basement of the Central Andes: Constraints from Bolivian crustal xenoliths. GSA Bulletin 125:985-997.

Miller CF, Wark DA (2008) Supervolcanoes and their explosive supereruptions. Elements 4:11-16

Morgan LA, McIntosh WC (2005) Timing and development of the Heise volcanic field, Snake River Plain, Idaho, western USA. GSA Bulletin 117 (3-4):288-306

Petrone CM, Bugatti G, Braschi E, Tommasini S (2016) Pre-eruptive magmatic processes re-timed using a non-isothermal approach to magma chamber dynamics. Nature communications $7: 12946$

Reid MR (2008) How long does it take to supersize an eruption? Elements 4:23-28

Robock A, Ammann CM, Oman L, Shindell D, Levis S, Stenchikov G (2009) Did the Toba volcanic eruption of $\sim 74$ ka BP produce widespread glaciation? Journal of Geophysical Research: Atmospheres (1984- 2012) 114(D10)

Samoza R (1998) Updated Nazca (Farallon)-South America relative motions during the last $40 \mathrm{My}$ : implications for mountain building in the central Andean region. Journal of South American Earth Science 11:211-215.

Sigl M, Winstrup M, McConnell JR et al. (2015) Timing and climate forcing of volcanic eruptions for the past 2,500 years. Nature 523:543-549

Scheuber E, Bogdanic T, Jensen A, Reutter K-J (1994) Tectonic development of the North Chilean Andes in relation to plate convergence and magmatism since the Jurassic. In: Reutter, K.-J., Scheuber, E. \& Wigger, P. (Herausgeber): Tectonics of the Southern Central Andes, S. 121139 , Springer.

Scheuber E, Giese P (1999) Architecture of the Central Andes a compilation of geoscientific data along a transect at $21^{\circ} \mathrm{S}$. Journal of South American Earth Sciences 12:103-107.

Schmincke HU (2007) The Quaternary volcanic fields of the east and west Eifel (Germany). In: Ritter JRR \& Christensen UR (ed) Mantle Plumes, a Multidisciplinary Approach. Springer, Berlin, pp 241-322.

Schmincke HU (2008) Quaternary volcanism of the east and west Eifel (Central Europe). In: McCann $\mathrm{T}$ (ed) Geology of Central Europe. Geological Society, London, pp 1318-1333.

Schmitt AK, Wetzel F, Cooper KM, Zou H, Wörner G (2010) Magmatic longevity of Laacher See volcano (Eifel, Germany) indicated by U-Th dating of intrusive carbonatites. J Petrol 51:10531085.

Self S, Blake S (2008) Consequences of explosive super-eruptions. Elements 4:41-46

Storey M, Roberts RG, Saidin M (2012) Astronomically calibrated 40Ar/39Ar age for the Toba supereruption and global synchronization of late quaternary records. Proc Natl Acad Sci USA. 109 (46): 18684-18688 
Tassara A, Götze HJ, Schmidt S, Hackney R (2006) Three-dimensional density model of the Nazca plate and the Andean continental margin. Journal of Geophysical Research: Solid Earth 111:1978-2012.

Thorpe RS, Francis PW, Hammill M, Baker MCW (1982) The Andes. In: Thorpe RS (ed.) Andesites: Orogenic Andesites and related Rocks. Wiley and Sons, New York: 187-205.

Viereck L (1984) Geologische und petrologische Entwicklung des pleistozänen Vulkankomplexes Rieden, Ost-Eifel, Bochumer geol. geotechn. Arbeiten 17.

Wedepohl KH, Baumann A (1999) Central European Cenozoic plume volcanism with OIB characteristics and indications of a lower mantle source. Contrib Mineral Petrol 136:225-239.

Wilson CJN (2001) The 265 ka Oruanui eruption, New Zealand: an introduction and overview. Journal of Volcanology and Geothermal Research 112:133-174

Wilson M, Downes H (1991) Tertiary quaternary extension-related alkaline magmatism in Western and Central Europe. J Petrol 32:811-849

Wörner G, Hammerschmidt K, Henjes-Kunst F, Lezaun J, Wilke H (2000) Geochronology (40Ar/39Ar, K-Ar and He-exposure ages) of Cenozoic magmatic rocks from northern Chile $\left(18-22^{\circ} \mathrm{S}\right)$ : implications for magmatism and tectonic evolution of the central Andes. Revista Geológica de Chile 27 (2):205-240.

Wörner G, Schmincke HU (1984a) Mineralogical and chemical zonation of the Laacher See tephra sequence (East Eifel, W. Germany). J Petrol 25:805-835.

Wörner G, Schmincke HU (1984b) Petrogenesis of the zoned Laacher SeeTephra. (East Eifel, W. Germany). J Petrol 25:836-851

Wörner G, Viereck L, Plaumann S et al (1988). The quaternary Wehr volcano: a multiphase evolved eruption center in the East Eifel Volcanic Field (FRG). Neues Jahrbuch für Mineralogie, Abhandlungen 159:73-99.

Yuan X, Sobolev SV, Kind R (2002) Moho topography in the Central Andes and its geodynamic implications. Earth and Planetary Science Letters 199:389-402.

Zandt G, Velasco AA, Beck S (1994) Composition and thickness of the southern Altiplano crust, Bolivia. Geology 22:1003-1006. 


\title{
Chapter 2: Zoning and exsolution in alkali feldspars from Laacher See volcano (Western Germany): constraints on temperature history prior to eruption
}

\author{
Smruti Sourav Rout, Gerhard Wörner
}

Geowissenschaftliches Zentrum, Georg-August-Universität (GZG), Goldschmidtstrasse 1, 37077 Göttingen, Germany

\begin{abstract}
:
Compositional zoning and exsolution patterns of alkali feldspars in carbonatite-bearing cognate syenites from the $6.3 \mathrm{~km}^{3}$ (D.R.E) phonolitic Laacher See Tephra (LST) deposit in western Germany (12.9 ka) are reported. These rocks represent the cooler outer portion and crystal-rich products of a cooling magma reservoir at upper crustal levels. Major and trace element difference between cores and rims in sanidine crystals represent two generations of crystal growth separated by unmixing of a carbonate melt. Trace element differences measured by LA-ICPMS are in accordance with silicate-carbonate unmixing. Across the corerim boundary, we extracted gray scale profiles from multiple accumulations of back-scattered electron images. Gray scales directly represent $\mathrm{K} / \mathrm{Na}$ ratios owing to low concentrations of $\mathrm{Ba}$ and $\mathrm{Sr}(<30 \mathrm{ppm})$. Diffusion gradients are modeled to solve for temperature using known preeruptive U-Th zircon ages (0-20 ky) of each sample (Schmitt et al. 2010). Estimated temperatures range from $630{ }^{\circ} \mathrm{C}$ to $670{ }^{\circ} \mathrm{C}$. For the exsolution boundaries, a diffusive homogenization model is constrained by the solvus temperature of $\sim 712-725{ }^{\circ} \mathrm{C}$ and gives short time scales of only 15-50 days. Based on our results we present a model for the temperature-time history of these rocks. The model also constrains the thermal variation across the cooling crystal-rich carapace of the magma reservoir over 20 ka and suggests a thermal reactivation of cumulates, the cooling carapace, and probably the entire system only a few years prior to the explosive eruption of the remaining molten core of the phonolitic magma reservoir.
\end{abstract}

Keywords: Diffusion chronometry, magma storage, phonolite, carbonate unmixing, cold storage, BSE images 


\subsection{Introduction}

Knowing rates of magmatic processes and the time-scales of crystal residence and storage of magmas are key factors in understanding the pre-eruptive history of large and potentially dangerous magma systems. Such studies can serve as essential tools in volcanic hazard assessment and risk management for active volcanic regions. Some of the most hazardous volcanoes, especially silicic volcanoes, have long-lived reservoirs that may store magmas of variable crystallinity for hundreds to thousands of years. Yet the time for (re-)activation and accumulation of large eruptible magma volumes appears to be relatively short (Cooper and Kent 2014; Bachmann and Bergantz 2008; Rubin et al. 2017). This has led to an intense discussion about the significance of crystal mush reactivation and the rates at which large volumes of eruptible magma can form prior to eruption (Bachmann and Bergantz 2008; Reid 2008; Ellis et al. 2014; Rubin et al. 2017; Cooper and Kent 2014; Barboni et al. 2016; Annen et al. 2008; Huber et al. 2012).

The temperature, pressure and compositional changes during storage and evolution of magmas are encoded in the composition of growth zones of minerals that crystallize from the melts (Chakraborty 2008; Costa and Chakraborty 2004; Morgan and Blake 2006; Costa and Morgan 2010; Ginibre et al. 2007). In order to constrain the rates of igneous processes during the evolution of magmatic systems and their crystals, two principal methods have been developed in the past two decades. One is the direct dating of crystals by short-lived U-series isotopes (e.g. Hawkesworth et al. 2000; Hawkesworth et al. 2004; Schmitt 2011; Condomines et al. 1988) that provides insights into their time of formation and thus give minimum values for the age and storage duration of magmas. For example, ${ }^{230} \mathrm{Th}^{226} \mathrm{Ra}$ dating applied to Santorini (Zellmer et al. 2000) and Kilauea Volcano, Hawaii (Cooper et al. 2001), and applications of U-Th-Ra disequilibria to MORB and OIB (Condomines et al. 1988) constrain time-scales of fractional crystallization, magma transport and residence from hundreds up to $10^{5}$ years. A second approach to estimate residence time and ages of crystals is based on diffusion speedometry of zoned phenocrysts which has been applied, for example, to plagioclase (Zellmer et al. 1999; Costa et al. 2003), pyroxene (Morgan et al. 2004; Chamberlain et al. 2014), olivine (Costa and Dungan 2005; Costa and Chakraborty 2004), quartz (Chamberlain et al. 2014) and sanidine (Chamberlain et al. 2014; Iovine et al. 2017). 
Cooper and Kent (2014) summarized, combined, and systematized earlier studies and compared diffusion ages to U-series ages for a large range of small to large, mafic to evolved magma systems. Particularly for longer-lived silicic systems, it appears that diffusion times, obtained for a temperature well above diffusion threshold are invariably less than absolute crystal ages recorded by U/Th isotopes. Apparently, the crystals must have spent a significant portion of their "life" at low temperatures where diffusion is negligible. Thus, interpreting residence times from modeling diffusion gradients critically depends on the thermal history of a crystal. However, the exact temperature history of older crystals in a magmatic system is difficult to constrain. This uncertainty has resulted in contrasting models of "warm" and “cold” crystal storage (Rubin et al. 2017; Barboni et al. 2016),

"Cold" storage suggests that crystals spend a large fraction of their lifetime at a significantly lower temperature, where they age with respect to their radiometric clock but diffusion rates are very low. They may be stored as part of a crystal mush (with $>\sim 50 \%$ vol. crystals, Bachmann and Bergantz 2008) at near solidus conditions for thousands of years (Reid 2008; Cooper and Kent 2014). More recent rejuvenation of crystals from such "cold storage" may then occur just prior to eruption during mafic recharge when the mush is melted to form an eruptible less-viscous magma (Girard and Stix 2009; Wolff et al. 2015; Bachmann and Bergantz 2008).

However, Morgan and Blake (2006) showed that in some cases diffusion time scales, constrained by a low temperature of $780{ }^{\circ} \mathrm{C}$, can also be as high as 200-300 ky. This, in contrast to cold storage, suggests a largely liquid magma body may be maintained at rather high temperatures. Such "warm storage" (Barboni et al. 2016), sustained by regular injections of hot and fresh magma, can keep the magma reservoir in an eruptible state for long time (>100 ka) (Gelman et al. 2013, Huber et al. 2012).

In this study, we address the issue of "cold" versus "warm" storage in a different way. We study cognate and crystal-rich ejecta of carbonatite-bearing syenites from the phonolitic Laacher See volcano. The Laacher See volcano, which erupted 12.9 ky ago (Baales et al. 2002), represents one of the largest Quaternary eruptions in central Europe. The magma system has been well studied with respect to the magmatic evolution of phonolite magmas and their associated cognate crystal-rich ejecta (e.g. Wörner and Schmincke 1984a, b; Harms and Schmincke 2000; Tait et al. 1989). For the latter, the formation ages have been determined by U-series zircon dating (Bourdon et al. 1994; Schmitt et al. 2010). Here we 
measure diffusion gradients in sanidines from these ejecta, but since the crystallization age is known for our samples, we can invert the diffusion modeling to extract information on storage temperatures and thus constrain temperature for "cold" storage conditions of crystals from the crystal mush of this magmatic system while its liquid core remained at high temperatures prior to eruption. This study is also a test for recently proposed mush-remelting models to explain compositional zoning in evolved pyroclastic deposits, such as the Laacher See tephra (Wolff et al. 2015).

\subsection{Geology and Petrography}

\subsubsection{Geological setting}

The Laacher See volcano belongs to the belt of Upper Tertiary to Quaternary intra-plate alkaline continental volcanism in central Europe. It is the largest and youngest eruptive center in the Quaternary East Eifel volcanic field which is located in the western part of the uplifted Paleozoic Rhenish Massif in western Germany (Fig. 1) (Schmincke 2007, 2008).

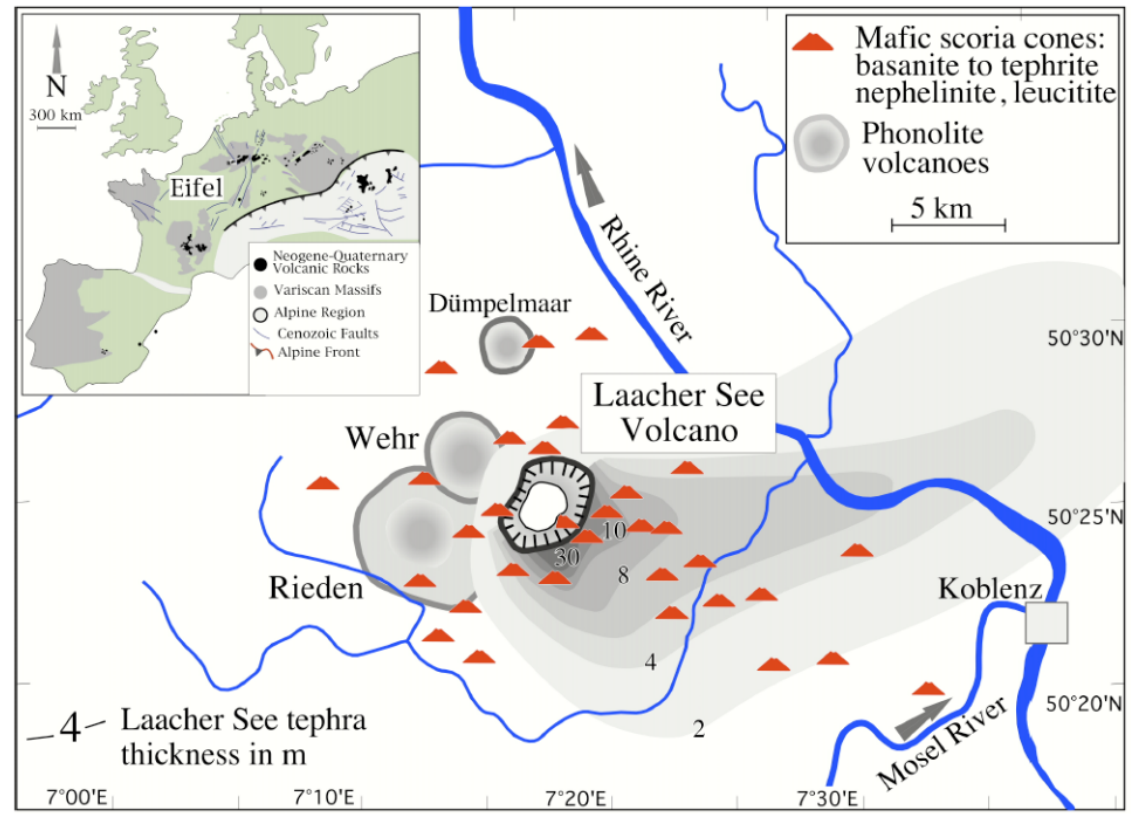

Fig. 1 Schematic map of East Eifel volcanic field with Laacher See ( $\sim 13 \mathrm{ka})$ in the east and Rieden $(\sim 460-360$ ka) and Wehr ( $215 \mathrm{ka})$ centers in the west and north-west.

Tertiary and Quaternary magmatism in central Europe produced mafic magmas ranging from basanites and alkali basalts to quartz tholeiite either in scattered centers in clustered volcanic fields or as a large shield volcano such as the Vogelsberg $\left(600 \mathrm{~km}^{3}, 15-16 \mathrm{Ma}\right)$ (Bogaard and 
Wörner 2003; Wedepohl and Baumann 1999; Wilson and Downes 1991). The East Eifel volcanic field (EEVF) has $\sim 100$ eruptive centers that mostly produced basanites, leucitites and nephelinites and their differentiation products during the past $440 \mathrm{ka}$ (Duda and Schmincke 1978; Wörner and Schmincke 1984; Bogaard et al. 1989a, b; Bogaard and Schmincke 1990; Schmincke 2007, 2008;). Mafic centers formed strombolian scoria cones, often with initial phreatomagmatic phases, and associated blocky lava flows as well as individual maars (Schmincke et al. 1973; Schmincke 2007, 2008). Earliest and poorly preserved ash deposits occurred 650 to $450 \mathrm{ky}$ ago (phase 1 and 2, Bogaard and Schmincke, 1990) erupted in the NW before the onset of Rieden volcano (between 430 and $380 \mathrm{ky}$ ).

The Rieden volcanic complex is the oldest of the three evolved centers and erupted phonolite and leucitititc tephra (between 430 and $380 \mathrm{ka}$, Bogaard et al. 1989a) representing a magma volume of probably more than $10 \mathrm{~km}^{3}$ (Viereck 1984; Bogaard and Schmincke 1990). The Wehr volcano produced phonolite to trachyte deposits at $215 \mathrm{ky}$ ago and evolved phonolitic tephra around 150 ka (Wörner et al. 1988; Bogaard and Schmincke 1990). This phase was followed by abundant basanite and tephrite scoria cones in the center and to the southeast of the field. The initiation of a last phase is the evolution of the phonolitic Laacher See magmatic system that started around $30 \mathrm{ky}$ ago (Schmitt et al., 2010) and lead to the eruption of the volcano 12,916 years BP (Baales et al. 2002) forming the prominent Laacher See crater (Schmincke 2007, 2008). This most recent eruption produced a major Quaternary tephra marker throughout central northern Europe (Bogaard and Schmincke 1984; Bogaard and Schmincke 1989b; Baales et al. 2002). Thus, distinct mantle-derived alkaline magmas were produced throughout the history of the volcanic field whereas voluminous evolved magmas were erupted intermittently. Duda and Schmincke (1978), Wörner and Schmincke (1984a,b) and Viereck (1984) documented the genetic relations between mafic (leucitite and basanite) and evolved magmas, i.e. leucite phonolites of the Rieden complex and hauyne-phonolite of the Laacher See volcano, respectively. Advanced crustal assimilation has only been documented for trachytes of the Wehr volcano (Wörner et al. 1988).

\subsubsection{The Laacher See eruption}

From the Laacher See eruptive center, a volume of about $6.3 \mathrm{~km}^{3}$ phonolitic magma was erupted within a time span of few days (Bogaard 1995). The top of the magma reservoir was estimated from xenoliths and experimental evidence to be at about 4 to $6 \mathrm{~km}$ (Wörner 1982; Harms and Schmincke 2000; Berndt et al. 2001; Harms et al. 2004) and the residual cumulate 
volume left after basanite to phonolite differentiation is in the order of $50 \mathrm{~km}^{3}$ (Wörner and Schmincke, 1984b). The stratigraphy of the Laacher See Tephra deposit (LST) is an inverted representation of the magma chamber which was mineralogically and chemically zoned (Wörner et al. 1983; Wörner and Schmincke 1984a, b). The Lower Laacher See Tephra (LLST), representing the volatile rich top of the magma chamber, is highly differentiated and enriched in incompatible major and trace elements. The Middle Laacher See Tephra (MLST) is crystal-poor representing the central and main volume of the chamber while the Upper Laacher See Tephra (ULST) is a crystal-rich mafic phonolite representing the base of the magma chamber. The final eruptive products that were deposited at the top of the ULST are hybrid magmas that contain forsteritic olivine, magnesian clinopyroxene and - rarely - small mantle peridotite xenoliths next to typical phonolitic minerals such as sanidine, hauyne, sodic plagioclase, amphibole, fassaitic clinopyroxene and titanite. These magmas formed by mixing and mingling between phonolite and a mafic basanite magma at the very last stage of eruption when the reservoir was recharged by new magma from below. Wörner and Wright (1984) argued that his mixing event may have been the result rather than trigger of the eruption.

The ULST deposit is particularly rich in a wide range of partly contact-metamorphosed and fenitized country rock xenoliths including Devonian slates, greenschists and rare amphibolitefacies metamorphic lithics. These crustal lithics are derived from the thermal aureole within the country rocks that was disrupted by the eruption. The thermal metamorphic overprint indicates that the magma reservoir has lost its heat for a significant amount of time to the country rock. Slow complementary cooling of the magma reservoir is also represented by cognate plutonic and cumulate ejecta. The cumulates are crystal-rich ( $<30 \%$ phonolitic glass) and are mineralogically divided (Tait et al. 1989) into mafic (dominantly pyroxene, amphibole, magnetite, apatite), intermediate (pyroxene, amphibole, mica, apatite, and 50-80\% feldspar) and syenitic (dominantly sanidine, variable amounts of plagioclase, haüyne and traces of pyroxene, amphibole, titanite, apatite). The abundance and variability in textures and composition of these cognate crystal-rich rocks represent the disruption of a complex crystallizing carapace and crystal mush that surrounded the magma reservoir.

Besides these cumulates, rare clasts of cognate carbonatite-syenite, up to $30 \mathrm{~cm}$ in diameter, are also found in the Upper Laacher See Tephra deposits. These carbonatites are among the youngest known worldwide (Woolley and Kjarsgaard 2008). Unlike other known occurrences of young carbonatite deposits, Laacher See carbonatites are intrusive in nature and intimately associated with highly differentiated interstitial phonolite glass (Liebsch 1996; Schmitt et al. 
2010). The trace element composition of these glasses is identical to the evolved phonolite magma as represented by aphyric LLST pumice composition. Crystals of the syenites also have faceted idiomorphic surfaces towards the interstitial, vesicular melt. This and the incompatible trace element-enriched, Ba- and Sr-poor composition excludes re-melting of syenites as a process forming the melt and supports the close genetic relation to the Laacher See phonolite magma. Intrusive carbonatites are also rarely found as xenoliths in deposits from the Reiden Volcano at Beller Berg and Auf Dickel (Riley et al. 1999).
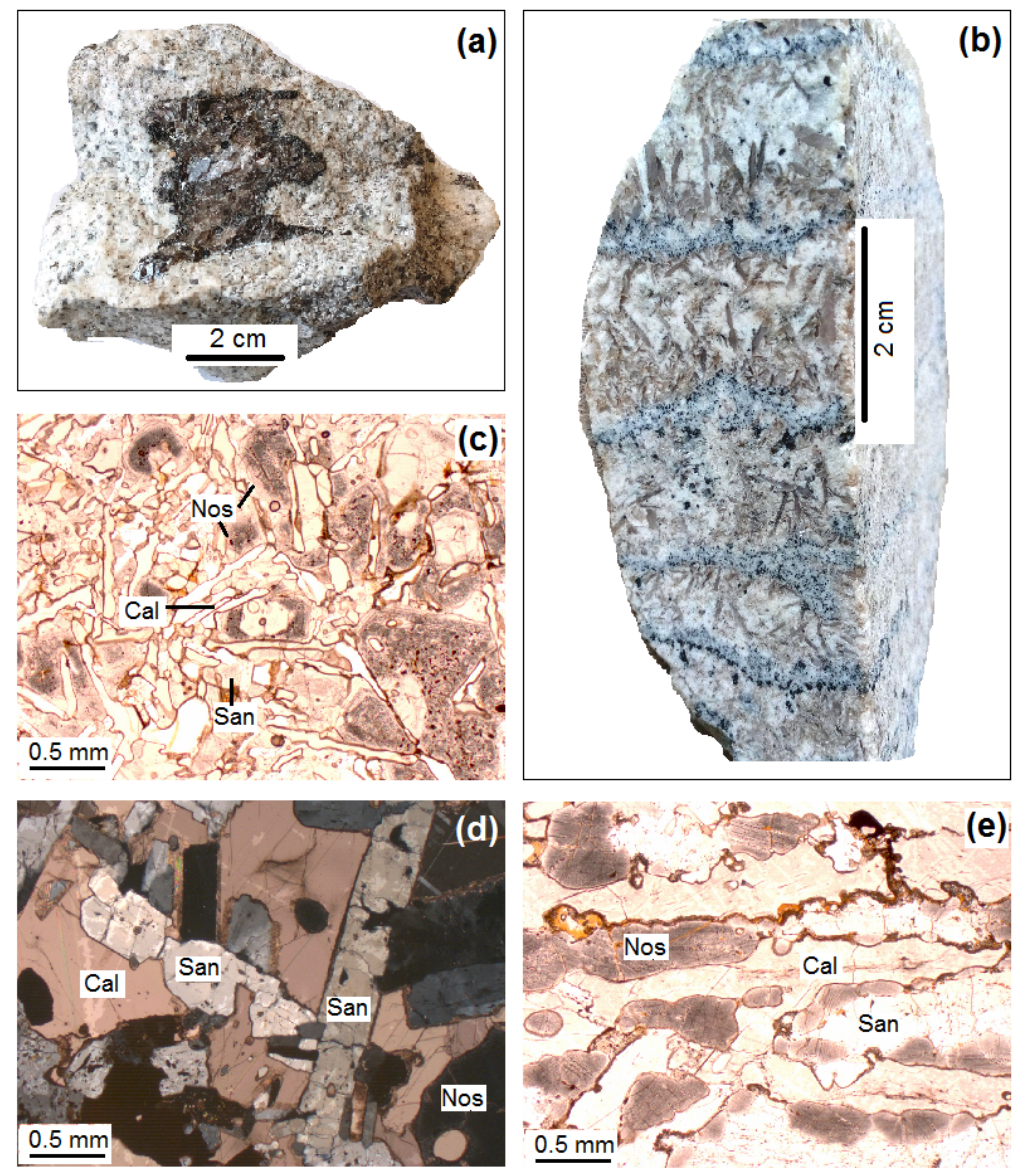

Fig. 2 Selected carbonatite-bearing syenitic xenolith samples from Laacher See Tephra indicating carbonatesilicate melt unmixing. (a) 148-L, centimeter scaled large sheared soevite droplet ( $\sim 100 \%$ calcite) in carbonatebearing nosean syenite indicating liquid immiscibility. (b) 222-L, comb-layered texture with centimeter scaled layers of carbonate alternating with domains of fine-grained sanidine and nosean. (c) 222-L under plane polarized light, sanidine co-precipitated with calcite and nosean; noseans have cores and inner rims abundant in $\mathrm{CO}_{2}$-rich inclusions. (d) 151-L under cross polarized light, sanidine grain is intruded by carbonates with nosean inclusions indicating a sequence of crystallization. (e) 337-L under plane polarized light, micrometer scaled alternating layers of carbonate and bands of sanidine crystallized with nosean. Abbreviations: San: sanidine, Nos: nosean, Cal: calcite. 


\subsubsection{Samples and petrography}

Carbonatite-bearing syenitic cumulates are petrographically divided into three categories: calcite bearing nosean syenites, calcite-bearing nosean syenites with sövite droplets and sövite syenites (Liebsch 1996). The term "sövite" is used for coarse-grained calcitic carbonatites (Liebsch 1996; Schmitt et al. 2010). The sövite droplets in calcite-bearing nosean syenites are up to $5 \mathrm{~cm}$ in diameter (Fig. 2a) and consist of nearly $100 \%$ pure calcite. All other groups contain different proportions of calcite ( $<1-76$ vol\%), sanidine (8-90 vol\%), nosean (3-50 vol\%) along with traces of clinopyroxene, biotite, albite and garnet (Schmitt et al. 2010). Other accessory minerals include magnetite, zircon, apatite, pyrochlore, titanite, cancrinite and allanite with vesicular interstitial glass $(<2$ vol\%). Vugs are abundant and may be filled with partly vesicular glass or euhedral crystals (e.g. sanidine, nosean, biotite). Common textures include cumulate and comb-layered textures. Glasses have generally $55-60 \mathrm{wt} \% \mathrm{SiO}_{2}$ and a higher Fe-content and appear light gray in back scattered electron images. The mineral constituents suggest a low water content for the bulk although the parental phonolite contained 5-6 wt\% water (Harms and Schmincke 2000; Harms et al. 2004). Previous work on U-series dating of zircons (Schmitt et al. 2010) and pyrochlor (Wetzel et al. 2010) from carbonatite-bearing syenites has estimated the range of ages for these rocks to be between 020,000 years prior to eruption.

The carbonatitic syenites are different from the typical cumulates, especially the felsic varieties, with respect to texture and mineral assemblage. Tait (1988) observed that the cumulates have interlocking crystal framework and contain glassy or microcrystalline matrix up to $30 \mathrm{vol} \%$. Individual crystals are $0.5-5 \mathrm{~mm}$ in size and sometimes show parallel textures typical of layered cumulate rocks. Feldspar content is dominated by sanidine followed by plagioclase and all felsic cumulates contain hauyne (10-15 vol\%). Only few of the sanidines share ragged outlines with surrounding glass and have holes filled with glass suggesting possible resorption and melting.

Among the syenite samples, sample 148-L shows an example of a centimeter sized sheared sövite "droplet" ( $\sim 100 \%$ calcite) immersed in a syenite host (Fig. 2). The close spatial relation as droplets, layers or interstitial carbonate in syenites suggest the co-existence of carbonate and silicate melts, probably related to phonolite-carbonatite melt unmixing (Brooker and Kjarsgaard 2010). Sample 222-L shows a comb-layered texture with centimeter long blades of carbonate crystals alternating with domains of coarse-grained sanidine and nosean. These 
coarse-grained crystals grow a $5 \mathrm{~cm}$ thick layer on intermittent $1 \mathrm{~cm}$ layers of carbonate-free finer-grained silicates. The nosean (up to $5 \mathrm{~cm}$ in size) in most samples contain numerous fluid inclusions tracing the growth of the crystals. Raman spectroscopy identifies the inclusions as pure $\mathrm{CO}_{2}$. Some nosean crystals also contain melt inclusions and small euhedral sanidine and calcite grains $(\sim 100 \mu \mathrm{m}$ in size). The sanidine layers and sheaves in sample 222$\mathrm{L}$ and 523-L suggest a relatively high rate of cooling. Sinuous grain boundaries, commonly observed in these samples are reminiscent of near-eutectic growth. Sample 127-L shows examples of carbonate crystallizing with nosean with equilibrated grain boundaries and sample 225-L shows euhedral calcite co-precipitated with euhedral sanidine (see supplementary material 1). Such petrographic observations suggest co-precipitation of carbonate, sodalite and sanidine together with a range of accessory minerals (apatite, zircon, pyrochlor, magnetite). Sample 151-L shows sanidine with embayments filled by carbonate with nosean inclusions indicating also a sequence of crystallization with sanidine forming first followed by co-precipitation of carbonate and nosean. Sample 337-L shows a comb-layering of carbonate and silicate bands of sanidine and nosean. Besides an usual enrichment of accessory minerals, it contains small (up to $200 \mu \mathrm{m}$ ) domains of coexisting carbonates and silicate glass (supplementary material 1). This suggests the existence of two immiscible, but physically un-separated melts in the interstices of an essentially crystalline rock. All carbonate-syenites irrespective of their particular texture show variable amounts (from a few up to $30 \%$ ) of evolved phonolite glass that is similar to the most evolved phonolite pumice erupted from the Laacher See volcano $\left(\mathrm{Na}_{2} \mathrm{O} / \mathrm{K}_{2} \mathrm{O}\right.$ from 0.7 to 2.5 ; at total alkalies of $17.3 \pm$ $1.1 \mathrm{wt} \%$; Liebsch 1996). This glass represents a phonolite melt that was present when the carbonatite component in these rocks crystallized. The presence of a pure calcite magmatic phase cannot be reconciled simply with the low pressure and temperature conditions inferred for the Laacher See magma reservoir (Wörner and Schmincke 1984a,b; Harms and Schmincke 2000) because pure calcite melts only at much higher temperature. Two possibilities exist: (1) the carbonate phase was sodic and recrystallized after unmixing or (2) water contents were very high (10's of percent, Wyllie and Tuttle 1959). In both cases, an alkali-rich fluid would have to be expelled from the crystallizing carbonatite melt. There is evidence for such a process in degassing pipes that are up to a few $\mathrm{cm}$ in diameter and cross larger syenite blocks. These pipes are aligned with euhedral crystals of nosean, sanidine, Ferich biotite, titanite, apatite, Fe-oxides and a plethora of accessory minerals, including zircon, pyrochlor and many others (Engelhaupt and Schüller 2015). Which of these processes are 
relevant is unclear, but the modeling and conclusions of this study on the zonation in the sanidines are not affected by this issue.

The alkali feldspars in the carbonatitic syenites are characterized by low anorthite content $(<2$ mol\%) and highly variable orthoclase content (5-40 mol\%). The sanidines are anhedral to euhedral and up to $\sim 3.5 \mathrm{~mm}$ in size. Ba and Sr contents are unsually low ( $<30 \mathrm{ppm}$ ) for most crystals. The variations in Or and Ab content in individual crystals are best observed in the back scattered electron images from electron microprobe. Alternating Or- and Ab-rich lamellae often form very distinct feather-like exsolution patterns (Fig. 3). Width of an individual lamella can vary between 2-10 $\mu \mathrm{m}$. However, the density of the exsolution patterns varies from core to rim of the crystals mirroring initial compositional zoning. Sanidines in intermediate and felsic cumulates are unzoned and have higher orthoclase content (45-70 mol\%) and without any exsolution textures (Tait, 1988; Tait et al., 1989). By contrast, sanidine phenocrysts in phonolite pumices are often distinctly zoned with clear, often oscillatory growth bands. Zoning tends to be more patchy in sanidine from within MLST and ULST (Ginibre et al., 2004). Exsolution features similar to the ones observed in syenites were only rarely observed in crystal-poor LLST pumice as low-An composite crystals that comprise of two distinct phases (sanidine and albite) and are characterized by inter-grown lamellae. These and other accessory crystals, such as zircon, cancrinite and annite likely derive from disaggregation of syenites from the magma camber walls into the crystal poor most evolved phonolite. This is in accordance with the U/Th data that indicate accidental older crystals in the topmost evolved and aphyric LLST phonolite (Bourdon et al., 1994). Another fundamental difference between sanidines in syenites and "normal" phenocrysts in the pumice or sanidine-rich cumulates are the extremely low contents of $\mathrm{Sr}$ and $\mathrm{Ba}$ which are below detection limit ( $\sim 7$ and $50 \mathrm{ppm}$ respectively) of the electron microprobe. In contrast, for phonolitic phenocrysts from pumices, Ginibre et al. (2004) reported Ba and Sr contents up to 1.6 and $0.4 \mathrm{wt} \%$ respectively. Only the low-An sanidine phenocrysts from the most differentiated part of LLST show $\mathrm{Ba}$ and $\mathrm{Sr}$ content below detection limit. These observations taken together indicate (1) a clear cognate relationship between the carbonatite-bearing syenites and the most evolved phonolite, but (2) a distinction to the phenocryst phases in the phonolite magma of the main reservoir that is represented by the erupted mass of the pumice. The syenites are therefore not a simple cumulate of phenocrysts from the phonolite but rather represent the almost completely crystallized equivalent of highly evolved melts and their unmixed carbonatitic component. Phonolite phenocrysts, cumulate crystals and syenites thus 
represent different components and stages of evolution and solidification of the phonolitic magma reservoir.
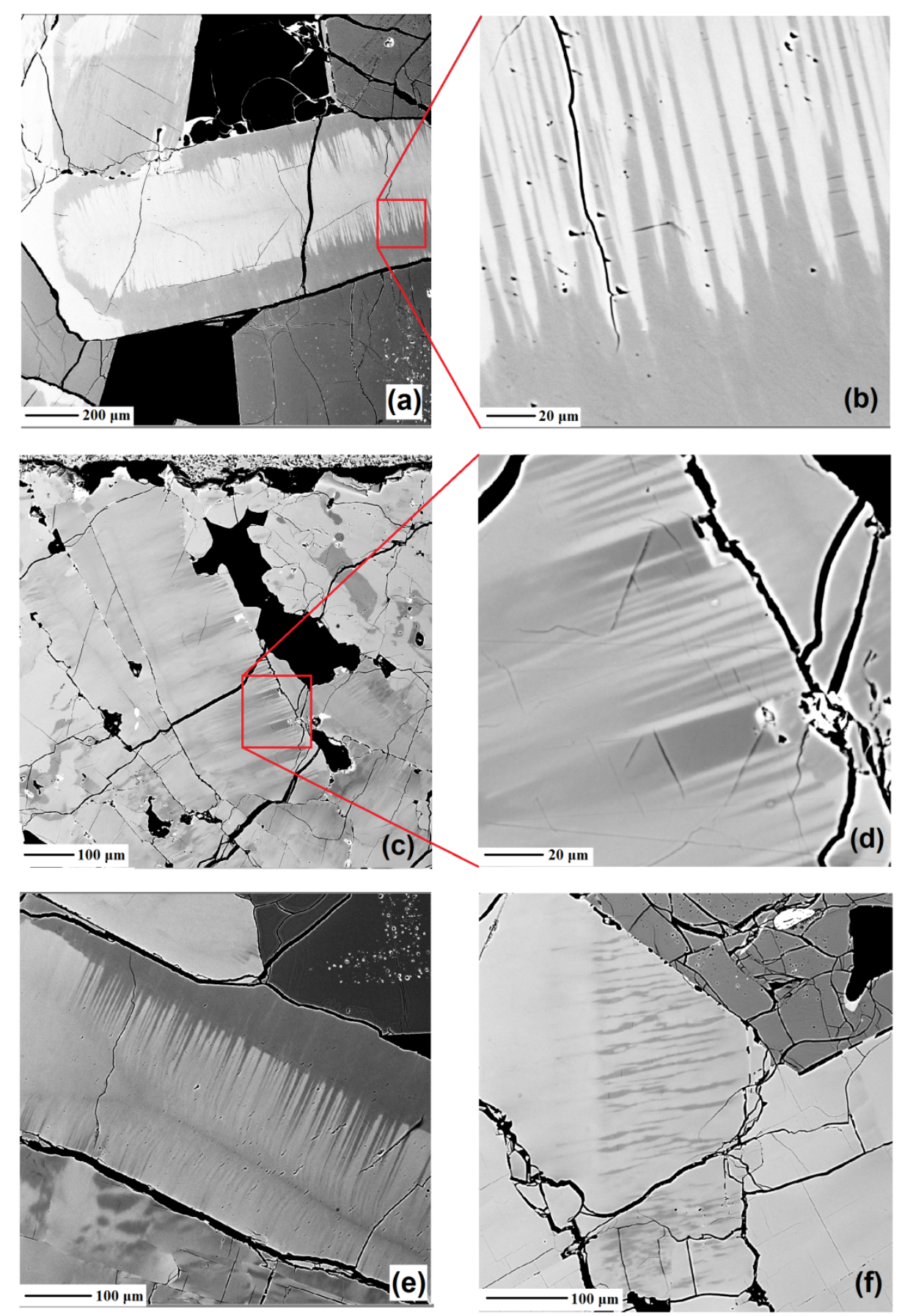

Fig. 3 Accumulated back scattered electron images of selected carbonatite-bearing syenitic cumulate samples from Laacher See Tephra illustrating the intra-grain compositional and textural features. The light gray colors denote orthoclase-rich phase and the darker gray colors suggest albite-rich phase. (a) 607-L2, sanidine 18; K-rich core and Na-rich rim separated by exsolved zone boundary. A few crystals (like the one in the center) have a Krich outer rim. There are later over-growth on some sanidines, which we interpret to be deposited by late stage fluids. Amygdales with late vapor-phase sanidine mineralisation are abundant in hand specimens. (b) Zoomed image of the exsolution patches in 607-L2, sanidine 18 showing alternative bands of K-rich and Na-rich bands. 
(c) 337-L, sanidine 1; indistinct zoning with prominent exsolution towards the rim. (d) Zoomed image of the exsolution in the rims of 337-L, sanidine 1. (e) zoning and exsolution pattern similar to (a). (f) Exsoluted rim with relatively lower $\mathrm{Na}$ content.

\subsection{Analytical methods}

Samples of carbonatite-bearing syenites analysed here cover the observed range of petrographic types and all were previously dated by U-series analyses of their zircons (Schmitt et al. 2010). Thin sections were polished and carbon-coated for the electron microprobe analysis. The same thin sections were used for laser ablation ICPMS as well.

Major, minor and trace element concentrations were obtained using both LA-ICPMS and combined energy dispersive and wavelength dispersive electron microprobe (EDS-WDSEMP) analyses. An Element 2 ICP-MS instrument (Thermo scientific, USA), coupled with a $193 \mathrm{~nm}$ ArF excimer laser ablation system (RESOlution M-50, Australian scientific instrument, Australia) at GZG, Universität Göttingen, was used for trace element analysis. The laser energy density was $\sim 3 \mathrm{Jcm}^{-2}$ with a repetition rate of $5 \mathrm{~Hz}$. Helium was employed as the carrier gas for transporting the ablated materials into the plasma. Each LA-ICPMS analysis incorporated a background acquisition of approximately $15 \mathrm{sec}$ followed by $35 \mathrm{sec}$ of data acquisition from the sample. Beam diameter for most of the measurements is $23 \mu \mathrm{m}$. However, the low concentrations of $\mathrm{Ba}$ and $\mathrm{Sr}(<10 \quad \mathrm{ppm})$ in the rims of some sanidines necessitated a beam diameter of $90 \mu \mathrm{m}$. NIST SRM 610 was used as the external reference material and a $100 \%$ oxide normalization strategy was used for the data quantification. ATHO-G, a certified international standard, worked as quality control material during the sequence of analysis. All data are given in supplementary material 5.

The microprobe analyses were performed at a JEOL JXA-8900R microprobe at GZG, Universität Göttingen. Measurements were done at $15 \mathrm{KV}$ accelerating voltage, $15 \mathrm{nA}$ beam current and $10 \mu \mathrm{m}$ beam size. Counting times for all the elements except $\mathrm{Ba}$ and $\mathrm{Sr}$ were 15 $\mathrm{sec}$ on the peak and $5 \mathrm{sec}$ on the background. For Ba and Sr, a maximum of $120 \mathrm{sec}$ on the peak and $60 \mathrm{sec}$ on the background were used but concentrations for most of the measurement points were below the detection limit (79 and $220 \mathrm{ppm}$ for $\mathrm{Ba}$ and $\mathrm{Sr}$ respectively). Calibration standards were albite for $\mathrm{Na}$, anorthite for $\mathrm{Si}, \mathrm{Ca}$ and $\mathrm{Al}$; sanidine for $\mathrm{K}$; hematite for $\mathrm{Fe}$; celsian for $\mathrm{Ba}$; and $\mathrm{SrTiO}_{3}$ for $\mathrm{Sr}$. The relative standard deviation for major oxides was below $2 \%$ and the absolute error calculated for minor oxides was between 0.003 and 0.03 wt $\%$. 
Accumulated back scattered electron (BSE) images were prepared by superimpositions of ten BSE image accumulations acquired in COMPO mode with $20 \mathrm{kV}$ accelerating voltage and 20 $\mathrm{nA}$ beam current with a slow scanning beam with acquisition time of $120 \mathrm{sec}$ per accumulation. In addition, X-ray line scans for K, Na and Ba were also acquired in COMPOmode stage scan condition to resolve the compositional transition in selected crystals. 50 accumulations per scan were acquired perpendicular to the core-rim boundary at $10 \mathrm{kV}$ accelerating voltage and $30 \mathrm{nA}$ beam current, with an acquisition time of $2 \mathrm{sec}$ per pixel. The data from EMP and LA-ICPMS are given in supplementary material 2, 3, 4 and 5.

Compositional profiles across the crystals from core to rim were guided by BSE images and positioned perpendicular to the zonation and exsolution boundaries. However, the compositional gradients across the exsolution boundaries were less than $10 \mu \mathrm{m}$ in length and could thus be only analyzed using gray scales from BSE images to achieve the required spatial resolution. Due to extremely low $\mathrm{Ba}$ and $\mathrm{Sr}$ content $(<30 \mathrm{ppm}), \mathrm{K}$ and $\mathrm{Na}$, are the two main elements of compositional variability in the sanidine crystals that control the gray scale value in accumulated back-scattered images. 


\subsection{Results and discussion}

In the accumulated back scattered images (Fig. 3), most sanidine grains have light gray cores and dark-gray rims. Quantitative EMS point analysis (supplementary material 2) shows that the cores are orthoclase rich $\left(0.4 \leq \mathrm{X}_{\mathrm{Or}} \leq 0.6\right)$ and albite poor compared to the rims $\left(\sim 0.1 \leq \mathrm{X}_{\mathrm{Or}} \leq 0.3\right)$ (Fig. 4). A sharp contrast in $\mathrm{Ba}$ and $\mathrm{Sr}$ is also seen between core and rim even though microprobe and LA-ICPMS show overall very low Ba and Sr-content (1-30 ppm). At the transition zone between core and rim, we observe feathery exsolution structures where darker bands indicate intergrowth of Na-rich and lighter bands K-rich sanidine. The relative amounts of K-rich feldspar decrease across the transition zone between core and rim indicating the previous existence of a systematic K-Na zonation prior to exsolution. There are several issues here that need to be addressed: (1) what is the cause for the distinctly different compositions of core and rim, (2) can the compositional gradient between core and rim be reconstructed and modeled for diffusion, and (3) what are the processes and conditions by which exsolution textures developed.

\section{(1) What is the cause for core-rim compositional contrast in zoned sanidine?}

The trace element data from La-ICPMS (supplementary material 5) suggests that, in the zoned sanidine grains, there is a significant $80-90 \%$ drop in Ba concentration and 40-50\% drop in $\mathrm{Sr}$ concentration in the rims compared to the cores. Upon further analysis, apart from $\mathrm{K}, \mathrm{Na}, \mathrm{Ba}$ and $\mathrm{Sr}$, prominent changes in other elements like $\mathrm{Nb}, \mathrm{La}, \mathrm{Ce}, \mathrm{Eu}, \mathrm{Ga}, \mathrm{Rb}, \mathrm{Cs}, \mathrm{Pb}$ and $\mathrm{Li}$ were observed as well (Fig. 5a). These distinct sanidine core vs. rim compositions in a rock that has silicate and carbonate compositional components indicate that core and rim may have been in equilibrium with distinct silicate melts before and after a carbonatite-phonolite unmixing event. In that case, this process should be reflected in the trace element disparity between the two sanidine compositions. In such a case, the relative concentrations of a trace element in the sanidine core versus rims should reflect compositional variations in the phonolite melt as they are controlled by silicate-carbonatite distribution coefficients during the unmixing event. We tested this hypothesis by calculating the apparent silicate-carbonate distribution coefficient from the variation of trace elements in the sanidine, using the carbonate-silicate volume fraction (Liebsch 1996) and the most evolved phonolite melt composition (sample 1002 from Wörner and Schmincke 1984a). Estimated values are indeed consistent with experimental data on trace element partitioning between silicate and carbonatite melts (Veksler et al. 1998; Hamilton et al. 1989; Jones et al. 1995; Veksler et al. 2012; Martin et al. 2013) as shown in 
Fig. 5a. The estimated partition coefficients also match well with empirical data by Liebsch (1996) based on analysed syenite - carbonatite pairs from Laacher See rocks (Fig. 5b).

For the distribution of alkali elements, experimental data show a strong dependence of silicate-carbonatite unmixing on the amount of water in the system. Our Na-K partitioning estimates and those of Liebsch (1996) data match best with the partitioning data for anhydrous $\left(\leq 0.04 \mathrm{wt} \% \mathrm{H}_{2} \mathrm{O}\right)$ alkalic and silica undersaturated systems at $1150-1260{ }^{\circ} \mathrm{C}$ and 1-3 GPa (Martin et al. 2013). For anhydrous systems, Martin et al. (2013) report a decrease in $\mathrm{K} / \mathrm{Na}$ ratio (by a factor of $\sim 0.5-0.85$ ) in the silicate melt after the carbonate exsolution similar to the decrease in $\mathrm{K} / \mathrm{Na}$ ratio (by a factor of $\sim 0.4-0.7$ ) that we derive from core to rim variations of the zoned sanidine crystals. Apart from $\mathrm{H}_{2} \mathrm{O}$-content, partitioning of $\mathrm{K}$ and $\mathrm{Na}$ is also heavily dependent on $\mathrm{K} / \mathrm{Na}$ ratio. Thus, this agreement with the anhydrous experimental data suggests that phonolite-carbonatite unmixing in the Laacher See magma chamber was preceded by significant degassing of water.

This interpretation is supported by zoned nosean crystals from the carbonatite-syenites: Nosean cores are abundant with fluid and $\mathrm{CO}_{2}$ inclusions that are negligible to absent in the distinct rim overgrowths. The rims of nosean, by contrast, show carbonatite inclusions and intimate intergrowth with carbonate (Fig. 2c, d and e) indicative of co-precipitation of both. This suggests two melts separated by a carbonate-silicate unmixing event that led to exsolution of a carbonate melt which was in equilibrium with the silicate melt. The core and rim of sanidine and nosean crystals formed prior and after this unmixing event, respectively.

\section{(2) Can the compositional gradient between core and rim be reconstructed and modeled for diffusion?}

We can best quantify the original compositional gradient via gray scale area profiles (known as swath profiles) that cover broader areas across the exsolved parts of the core-rim transition zone (Fig. 6a and c). Unmixing may be a continuous process in the Laacher See magma system, as is indicated by the range of U/Th model ages for the unmixing process for different samples (13.7 to $19.7 \mathrm{ka}$; Schmitt et al. 2010). However, for each individual sample, the unmixing event will be short with respect to the overall residence time scales (thousands of years) resulting in a sharp compositional change between core and rim of the sanidines. In this case, unmixing should have produced a relatively abrupt compositional step across the original boundary between the core and rim of the sanidines. The sinusoidal boundary between core and rim suggests resorption before regrowth, further evidence for an initially 
abrupt compositional break. Such a sharp compositional step function in the Na-K ratio may then have been smoothed out by diffusion and this gradient obtained from average gray scale profile lends itself to diffusion modeling.

The gray scale values are a direct proxy for the $\mathrm{K} / \mathrm{Na}$ ratio owing to insignificant variation in other major elements. Although heavier elements like Ba and Sr vary from core to rim, their concentration is extremely low $(<30 \mathrm{ppm})$ and have no effect on back-scattered electron intensities. When tested for correlation, the gray-scale values gave a linear correlation with $\mathrm{k} / \mathrm{K}+\mathrm{Na}$ ratio (Fig. 4d). The gray-scale values also gave a correlation coefficient of 0.99 with the Or-content in the quantitative microprobe point analyses that were measured along the same profiles (supplementary material 6). The gradients in gray scale profiles can thus be used directly to estimate the time scales of $\mathrm{K}-\mathrm{Na}$ interdiffusion across the zone boundary (Fig. 6a). A positive correlation is indeed observed between the diffusive lengths and the absolute zircon ages for each sample. This suggests that the observed compositional gradients are the result of diffusion-driven homogenization which smoothed the gradient with time.

To estimate the lateral spatial resolution of our gray-scale gradients, a Monte-Carlo simulation was done. The simulation suggests that $95 \%$ of the BS electrons come from a depth of $<450 \mathrm{~nm}$ and a lateral radius of $<200 \mathrm{~nm}$ (supplementary material 6). Therefore, the short diffusion profiles (2-6 $\mu \mathrm{m}$ in length) that we used for modeling exsolution boundaries is sufficient at $<200 \mathrm{~nm}$ lateral resolution to fully document the diffusion gradient. Moreover, any higher resolution will only make the profile sharper if not the same and in that case, the estimated time-scales will be further shorter. We are, however, concerned in estimating a maximum time-scale between activation and eruption. Since the obtained maximum timescales are already very short (see below), any shorter time-scales would not affect our conclusions. 

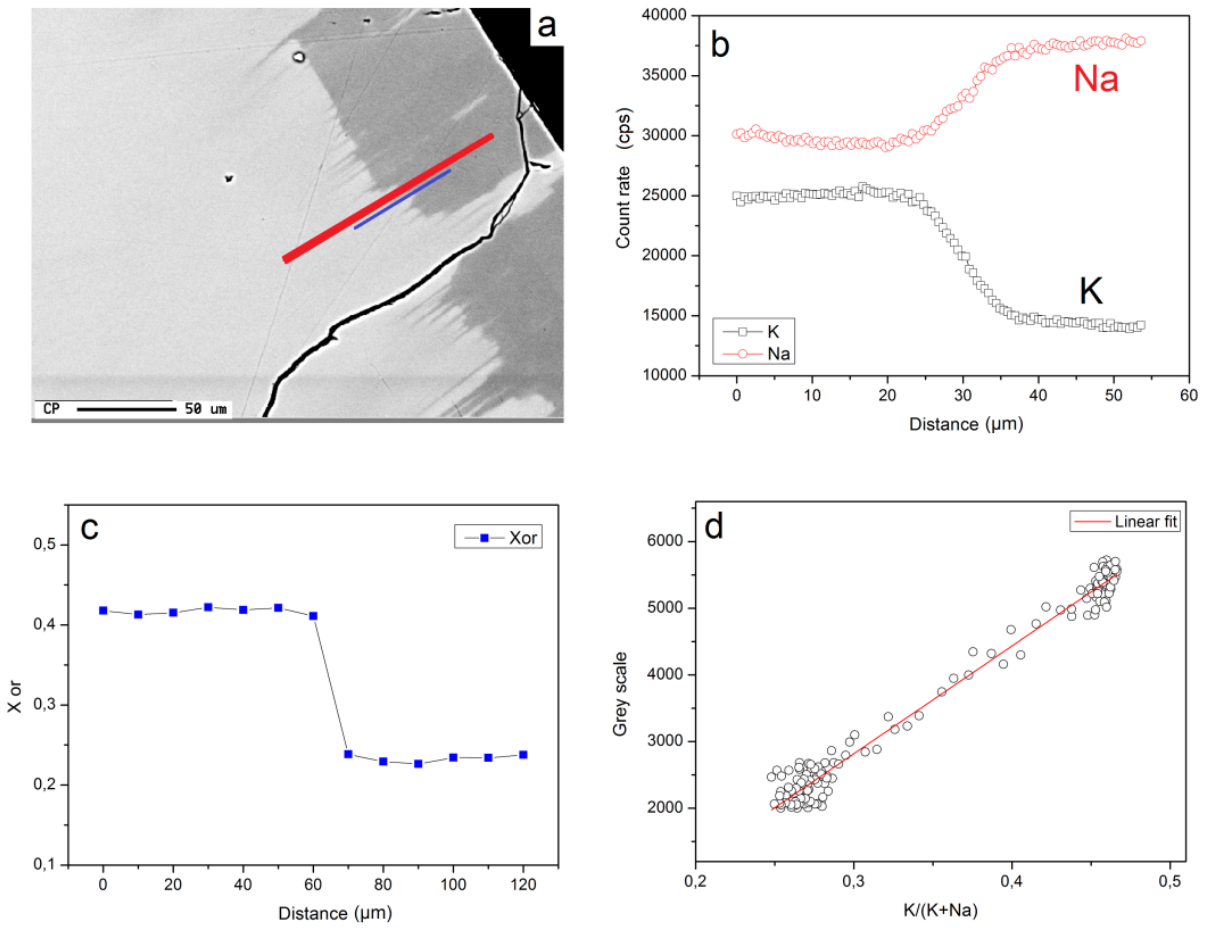

Fig. 4 (a) Accumulated BSE image of a selected sample (607-L2, sanidine 10). The red line denotes the trace of the compositional profile obtained across the core-rim boundary through quantitative line analysis in EPMA and the blue line denotes the trace of X-ray scan across the same boundary. (b) K and Na count rates (c) Orthoclasecontent $\left(\mathrm{X}_{\mathrm{Or}}\right)$ from line analysis $(\mathrm{d})$ The correlation between $\mathrm{K} /(\mathrm{K}+\mathrm{Na})$ from $\mathrm{b}$ and gray-scale values along the line (blue) of x-ray scanning.

After a least square fitting using algorithms run in MATLAB, OriginR and MATHEMATICA, the effective diffusion coefficient and the corresponding effective storage temperatures are calculated based on the known U-series absolute ages (after subtracting the eruption age of $12.9 \mathrm{ka}$ ) obtained by Schmitt et al. (2010) for these samples. This is reverse to what is generally done for diffusive analysis, where the storage time-scales are obtained by modeling diffusion gradients for a given temperature. This approach, however, assumes that the zircons and feldspars, for which diffusion modeling is done here, have the same age. We argue that this is a valid assumption because, firstly, both the sanidine and the zircon formed from the phonolite melt upon cooling. Secondly, the model ages for carbonate unmixng from phonolite (Schmitt et al. 2010) are correlated with Zircon ages and both values are similar within error (supplementary material 6). Except one sample (604-L), crystallization and unmixing ages for all other samples are significantly older (by several ka) than eruption. Finally, Schmitt et al. (2010) also calculated a calcite-zircon oxygen isotopic exchange temperature using the lowest calcite $\delta^{18} \mathrm{O}$ value, which yields $690 \pm 100^{0} \mathrm{C}$ that is similar to the average Ti-in-zircon thermometry result. The trace element data support our interpreation that 
the carbonate unmixing happened during sanidine growth and the above temperature is also just below the sanidine liquidus determined for the evolved phonolite. These arguments suggest that the zircon formation was close to carbonate unmixing and the formation of both overlapped with sanidine growth.
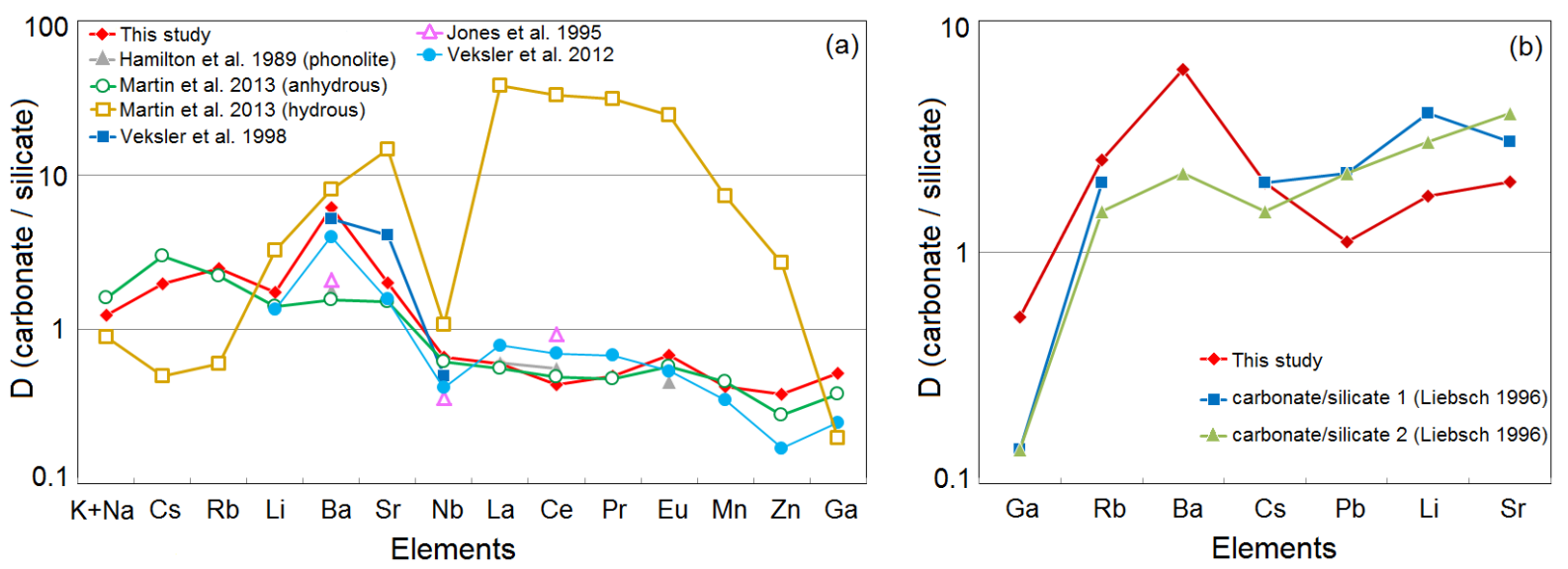

Fig. 5 Comparison of the estimated trace-element partition coefficient values between silicate and carbonate against existing experimental and empirical data. (a) Comparison with experimentally determined partition coefficient by Veksler et al. 1998 (965-1015 $\left.{ }^{\circ} \mathrm{C} \& 0.8-0.9 \mathrm{kbar}\right)$; Veksler et al. $2012\left(650-1100{ }^{\circ} \mathrm{C} \&\right.$ 0.7-1 kbar); Hamilton et al. 1989 (phonolite, $1150{ }^{\circ} \mathrm{C} \& 1 \mathrm{kbar}$ ); Jones et al. $1995\left(1100{ }^{\circ} \mathrm{C} \& 10 \mathrm{kbar}\right.$ ); Martin et al. 2013 (anhydrous alkaline silica undersaturated systems and hydrous potassic and phonolitic systems, $1160-1240{ }^{\circ} \mathrm{C} \&$ 10-30 kbar). Distribution coefficients are shown for $\mathrm{Na}$ and $\mathrm{K}$ to show overall partition of alkalis. (b) Comparison with empirical data obtained by Liebsch 1996 for two types of samples: calcite-bearing nosean syenites with soevite drops (1) and soevite-syenites (2).

\section{(3) What are the processes and conditions by which exsolution textures developed?}

Direct gray-scale profiles were extracted from high-magnification BSE images across the exsolution boundaries. At equilibrium, the phases would be totally separated resulting in a sharp compositional step function. However, the high spatial resolution of gray-scale profiles $(<0.5 \mu \mathrm{m})$ allows to document smoothed out gradients with width between 2 and $6 \mu \mathrm{m}$ (Fig. $6 b)$. This is best explained by a late stage heating event which caused the temperature to rise above the solvus. As a consequence, the previously unmixed phases start to mix again by interdiffusion. Considering this possibility, we modeled the exsolution boundaries for a possible forward diffusion. 


\subsubsection{Constraints on parameters used in diffusion modeling}

To model diffusion along the compositional gradients that have been described and interpreted above, the temperature and diffusivity must be constrained.

\section{Temperature}

We interpret the carbonatitic syenites to have initially formed as a cooling, crystal-rich carapace around the core of a phonolitic magma reservoir. The storage temperature for such rocks decreases away from the center of the magmatic core. Thus, it is hard to constrain a lower temperature limit to which these rocks where cooled prior to eruption. The upper limit of storage temperature should not exceed the temperature of crystallization of phenocrysts in the phonolite magma, which is estimated experimentally to be $750-760{ }^{\circ} \mathrm{C}$ at 115 to $145 \mathrm{MPa}$ pressure for the given evolved phonolite melt compositions (Harms et al. 2004). Their experiments also constrain the sanidine-in temperature at $\sim 750-775{ }^{\circ} \mathrm{C}$ for pressure between 75 and $125 \mathrm{Mpa}$. We thus take $750^{\circ} \mathrm{C}$ as the upper T-limit in our considerations.

The temperature of carbonate-silicate unmixing is assumed to be at around $\sim 750{ }^{\circ} \mathrm{C}$ based on experimental data on carbonate-silicate immiscibility (Brooker and Kjarsgaard 2010; Kjarsgaard et al. 1995). Similarly, the top of the solvus for sanidine is defined at $\sim 712-725{ }^{\circ} \mathrm{C}$ for $0.25 \leq \mathrm{X}_{\mathrm{Or}} \leq 0.5$ (Brown et al. 1989). Below this temperature, an orthoclase-rich phase exsolves from the albite-rich phase. The temperature of $\mathrm{Na}-\mathrm{K}$ exsolution that is observed in sanidines of the Laacher See syenites has to be very close to the top of the solvus as only the intermediate compositions in the transition between core and rim show exsolution. Core and rim would have remained above the solvus on both sides of this region. So, based on the composition of the fraction of the grains that show exsolution, a temperature of $710{ }^{\circ} \mathrm{C}$, i.e. just below the maximum of the solvus is used for modeling the gradients across the exsolution boundaries. This temperature is consistent with the observation of persistent interstitial glass in the syenites, indicating that the rocks had not cooled below the solidus. The effects of pressure and water content on the solvus are considered to be negligible (Parsons 1978; Morse 1970). As per Parsons (1978), the solvus would change by $<3{ }^{\circ} \mathrm{C}$ for the suggested pressure variation of $\pm 15 \mathrm{Mpa}$ (Harms et al. 2004) for the upper Laacher See magma chamber. A temperature change of $<3{ }^{\circ} \mathrm{C}$ will not significantly affect the diffusion. 

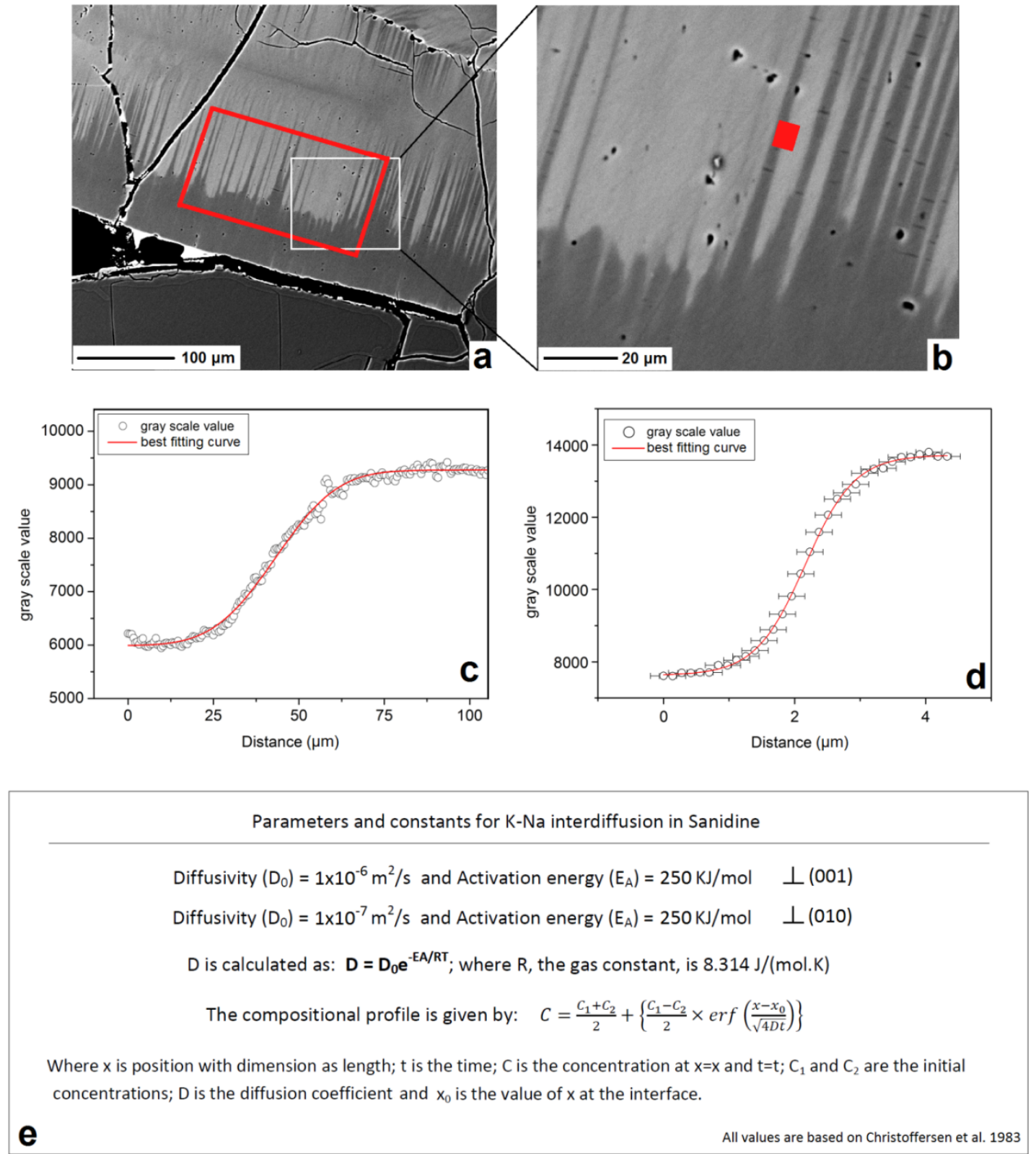

Fig. 6 (a) accumulated BSE image of a selected sanidine grain (607-L2 sanidine 4). The red rectangle encloses the area over which the swath profile (c) for gray-scale values is taken. (b) the zoomed-in view of (a), the solid red rectangle covers the area of the swath profile (d) for gray-scale values used for diffusion modeling across the exsolution boundary. The red curves in (c) and (d) are the best fitting curves obtained using MATLAB®and Origin ${ }^{\circledR}$. (e) Parameters, constants (after Christoffersen et al. 1983) and equations used for diffusion analysis, and calculation of average storage temperature. 


\section{Diffusivity}

There have been various experimental studies on $\mathrm{K}-\mathrm{Na}$ interdiffusivity in feldspars. Christoffersen et al. (1983) used adularia (Or89.6) and albite (Ab98.6) in a diffusion couple to study $\mathrm{K}-\mathrm{Na}$ interdiffusion in alkali feldspars for the compositional range of $0.1 \leq \mathrm{X}_{\mathrm{Or}} \leq 0.8$. Interdiffusivity values were obtained for a temperature of $900-1000{ }^{\circ} \mathrm{C}$ at pressures of $0.5-1.5$ Gpa. These data, when extrapolated, match well with values given by Brady and Yund (1983) for a temperature range between 600 and $650{ }^{\circ} \mathrm{C}$. Christophersen et al. (1983) report that K$\mathrm{Na}$ interdiffusion is dependent on both crystallographic orientation and composition.

Recent studies like Schäffer et al. (2014) and Petrishcheva et al. (2014) have directly determined the diffusion coefficients for $0.65 \leq \mathrm{X}_{\mathrm{Or}} \leq 0.99$ and the full diffusivity tensor for $0.85 \leq \mathrm{X}_{\mathrm{Or}} \leq 1$ respectively and are in good agreement with Christoffersen et al. (1983). However, the compositional range of most of our analyzed samples (both core and rim) lie in the range of $0.2 \leq \mathrm{X}_{\mathrm{Or}} \leq 0.5$. Therefore, we use the values provided by Christofferson et al. 1983 for this compositional range. The Christoffesen et al. (1983) data show very little variation for this $0.2 \leq \mathrm{X}_{\mathrm{Or}} \leq 0.5$ range in their $\log \mathrm{D}$ vs $\mathrm{X}_{\mathrm{Or}}$ curve, indicating that in this range the diffusivity is independent of the $\mathrm{X}_{\mathrm{Or}}$ composition. This allows us to use constant interdiffusion coefficients in our diffusion analyses. The diffusivity and activation energy data are summarized in Fig. 6e. We use the Arrhenius plot and diffusion coefficient data from Christoffersen et al. (1983) also to estimate the temperature dependence of the diffusion coefficients. Our used activation energy is in line with that shown by Schäffer et al. (2014). We also used the K tracer diffusion coefficient from Gilleti and Shanahan (1997) and the Na tracer diffsuion coefficient obtained by Perishchova et al. (2014) to estimate diffusion coefficients (for $0.2 \leq \mathrm{X}_{\mathrm{Or}} \leq 0.4$ ) which are of same order and similar magnitude as the values we used.

The diffusivity value is also dependent on the crystallographic orientation. Christophersen et al. (1983) found that the diffusivity is fastest normal to (001) and is slowest normal to (010). Petrographic observations suggest that in the selected samples, the core-rim boundaries are perpendicular to (001) and the exsolution lamellae are perpendicular to the core-rim boundaries. As the direction of diffusion is always normal to the diffusion boundary, for the core-rim boundaries, the direction of diffusion is in (001) plane, and for the exsolution boundaries, it is normal to (001). For modeling of core-rim boundary, we use diffusion coefficients perpendicular to (010) i.e. the lowest in (001) plane to obtain the maximum 
temperature. For the exsolution boundaries, we use diffusion coefficients normal to (001) which is about an order of magnitude higher. The values for directions parallel to [100] are $\sim 2$ times higher which makes a difference of $\sim 20^{\circ}$ in the calculated temperature. This is within the given error. For the exsolution boundaries we use diffusion coefficients normal to (001).

Effects of pressure and water content are considered to be insignificant as Yund (1984) suggest that the alkali interdiffusion in feldspars is independent of water pressure and confining pressure at least up to $2 \mathrm{Kbar}$ and $15 \mathrm{Kbar}$ respectively.

Table 1 Estimates of average storage temperature derived from zoned sanidines in carbonatitic syenites from Laacher See volcano along with their absolute ages given by Schmitt et al. 2010 and Wetzel et al. 2010.

\begin{tabular}{ccccc}
\hline Sample & \multicolumn{2}{c}{ Absolute Age (ky) } & \multicolumn{2}{c}{ Temperature $\left({ }^{\circ} \mathrm{C}\right)$} \\
\hline $523-\mathrm{L}$ & 15.5 & +2.5 & 674 & +66 \\
& & -2.5 & & -22 \\
& & +6.2 & 656 & +84 \\
$127-\mathrm{L}$ & 17.6 & -6.2 & & -29 \\
& & +7.7 & 635 & +50 \\
$337-\mathrm{L}$ & 21.7 & -7.2 & & -18 \\
& & +3.9 & 553 & +40 \\
$225-\mathrm{L}$ & 17.4 & -3.8 & & -16 \\
& & & 650 & +3 \\
$607-\mathrm{L} *$ & $\sim 17 *$ & & & -3 \\
\hline
\end{tabular}

*marked sample represents the sample without U-series age. For such a sample the age is taken as per petrographic similarity, the extent of diifusion length and the age of major carbonatite production event given by Schmitt et al. 2010. 


\subsubsection{Diffusion modeling}

\section{K-Na interdiffusion between core and rim}

Based on the measured compositional gradients and the parameters defined above, we now first analyze the boundary between sanidine cores and rims for $\mathrm{K}-\mathrm{Na}$ interdiffuison to derive the average storage temperature over the duration given by the U/Th zircon age of the rock. Fig. 6 shows an example of the calculation for sample 607-L2 using a swath profile across the core-mantle diffusion boundary. Estimated temperatures range from 553 to $674{ }^{\circ} \mathrm{C}$ and are given in Table 1 for all samples investigated together with U-Th ages determined by Schmitt et al (2010) on zircons from the same samples. The compound propagated error in the estimated temperature values include (1) errors in the absolute age determinations which accounts for $90-95 \%$ of the error, (2) the error in the diffusion coefficient and (3) the error in curve fitting that accounts for a maximum variation by only $3{ }^{\circ} \mathrm{C}$.

The exponential variation of diffusion coefficient with temperature (based on Christoffersen et al. (1983) defines a diffusion threshold temperature at $\sim 550{ }^{\circ} \mathrm{C}$ (supplementary material 7). To constrain the diffusion threshold in the case of a slowly cooling system, we used K-Na inter-diffusion in a conductively cooling magma chamber such as what is expected below the Laacher See volcano. The results (supplementary material 7) show that the K-Na interdiffusion would be extremely slow below $550{ }^{\circ} \mathrm{C}$ putting the apparent diffusion threshold temperature also at $\sim 550{ }^{\circ} \mathrm{C}$. The average storage temperatures estimated for most samples (Table 1) lie well above this diffusion threshold. This suggests that diffusion continued for the entire duration of storage and thus, the estimated values represent the effective storage temperatures over the storage time as constrained by the zircon U-Th ages. Depending on a combination between the width of the diffusion gradient and the zircon ages (i.e. duration of pre-eruptive storage) of a sample, the resulting temperatures vary.

This difference in calculated temperatures should relate to the distance from the core of the cooling magma chamber. Therefore sample 523-L, with a temperature of $674{ }^{\circ} \mathrm{C}$ should be closer to the core and was also formed more recently (i.e. closer to the time of eruption) as is indicated by its younger age relative to eruption. This is followed by samples 127-L and 337$\mathrm{L}$, which give lower temperatures $\left(656\right.$ and $\left.635^{\circ} \mathrm{C}\right)$ and thus should have crystallized earlier and resided at a larger distance from the magmatic core. The range of calculated temperatures estimated here is also in agreement with storage temperature between $600-700{ }^{\circ} \mathrm{C}$ for 
carbonatitic syenites proposed by Schmitt et al. (2010). However, sample 225-L gives a much lower temperature of $553{ }^{\circ} \mathrm{C}$. However, the diffusive lengths in $225-\mathrm{L}$ are also about two orders of magnitude shorter than those of the other samples. Since sample 225-L has undergone effective diffusion only for a very short period of time this could be the result of rapid cooling to $\sim 553{ }^{\circ} \mathrm{C}$, i.e. a temperature very close to the diffusion threshold below which diffusion is extremely slow or negligible. Thus, sample 225-L most likely represents a different storage environment either as relatively recent (with respect to eruption time) but small intrusive body e.g. a dike at some distance from the hot core where it was rapidly cooled and stored at near or below the diffusion threshold.

Table 2 Estimates of time scales obtained for diffusion across exsolution boundaries in the sanidines in carbonatite-bearing syenitic cumulates from Laacher See Tephra.

\begin{tabular}{lcc}
\hline Sample & $\begin{array}{c}\text { Homogenization time-scale for exsolution } \\
\text { (days) }\end{array}$ \\
\hline $127-\mathrm{L}$ & 31 & \pm 5 \\
$225-\mathrm{L}$ & 50 & \pm 7 \\
$337-\mathrm{L}$ & 28 & \pm 4 \\
$523-\mathrm{L}$ & 17 & \pm 3 \\
$607-\mathrm{L}$ & 15 & \pm 3 \\
$673-\mathrm{L}$ & 25 & \pm 4 \\
\hline
\end{tabular}

\section{K-Na uphill diffusion, formation, preservation, and smoothing of exsolution lamellae}

The range of effective storage temperatures that were estimated from core-to-rim interdiffusion is not only below the solvus but also well above the diffusion threshold for Na$\mathrm{K}$ uphill diffusion that formed the exsolutions. In principle, it is possible that the observed exsolutions formed early, i.e. directly after the formation and initial slow cooling of the syenites, and remained intact during the entire storage time. However, micron-sized exsolution lamellae would have completely re-equilibrated during short intermittent heating events to $725{ }^{\circ} \mathrm{C}$ (just above the solvus) within 5 to 7 years (supplementary material 8). Heating to higher temperature (e.g. $750{ }^{\circ} \mathrm{C}$ i.e. the maximum temperature in the phonolite) would result in equilibration times less than that. Sanidines in many samples do not have any exsolutions. Therefore, homogenous crystals, even in old syenites, either never exsolved or 
exsolution lamellae never exceeded a few microns in width and were homogenized in a short time by heating events. Based on these arguments, we cannot exclude heating and cooling episodes during storage of the crystals in the syenite, but high-Temperature episodes cannot have been too long (more than several hundreds of years) because of the low overall effective temperature during storage $\left(630\right.$ to $670{ }^{\circ} \mathrm{C}$ ). This means, however, that the exsolution textures that we observe must be rather recent (in the later part of storage) and formed by cooling and uphill diffusion within $\sim 6$ to 15 years (details in supplementary material 8 ) after a last heating episode prior to eruption.

An exsolution boundary between two feldspars would have been initially close to a perfect compositional step function. Compositional gradients across exsolution interfaces range from 2 to $5 \mu \mathrm{m}$. Even $2 \mu \mathrm{m}$ is above the spatial resolution allowed by the BSE images and thus, these gradients indicate late stage smoothing by interdiffusion that started to re-equilibrate the feldspar compositions. We modeled Na-K interdiffusion across these exsolution boundaries for a total of 35 grains from six samples. We used the solvus temperature (see above) to be the minimum temperature that gives maximum duration for the heating event of 15-50 days (Table 2). The conclusions from this are that (1) homogeneous crystals do not represent sanidines that had never cooled below solvus conditions but (2) may have been homogenized rather recently (within a few years) by a heating event just prior to eruption. Those crystals that do show exsolution textures must also have suffered heating, however at still shorter time scales (10 to 50 days) before eruption. 


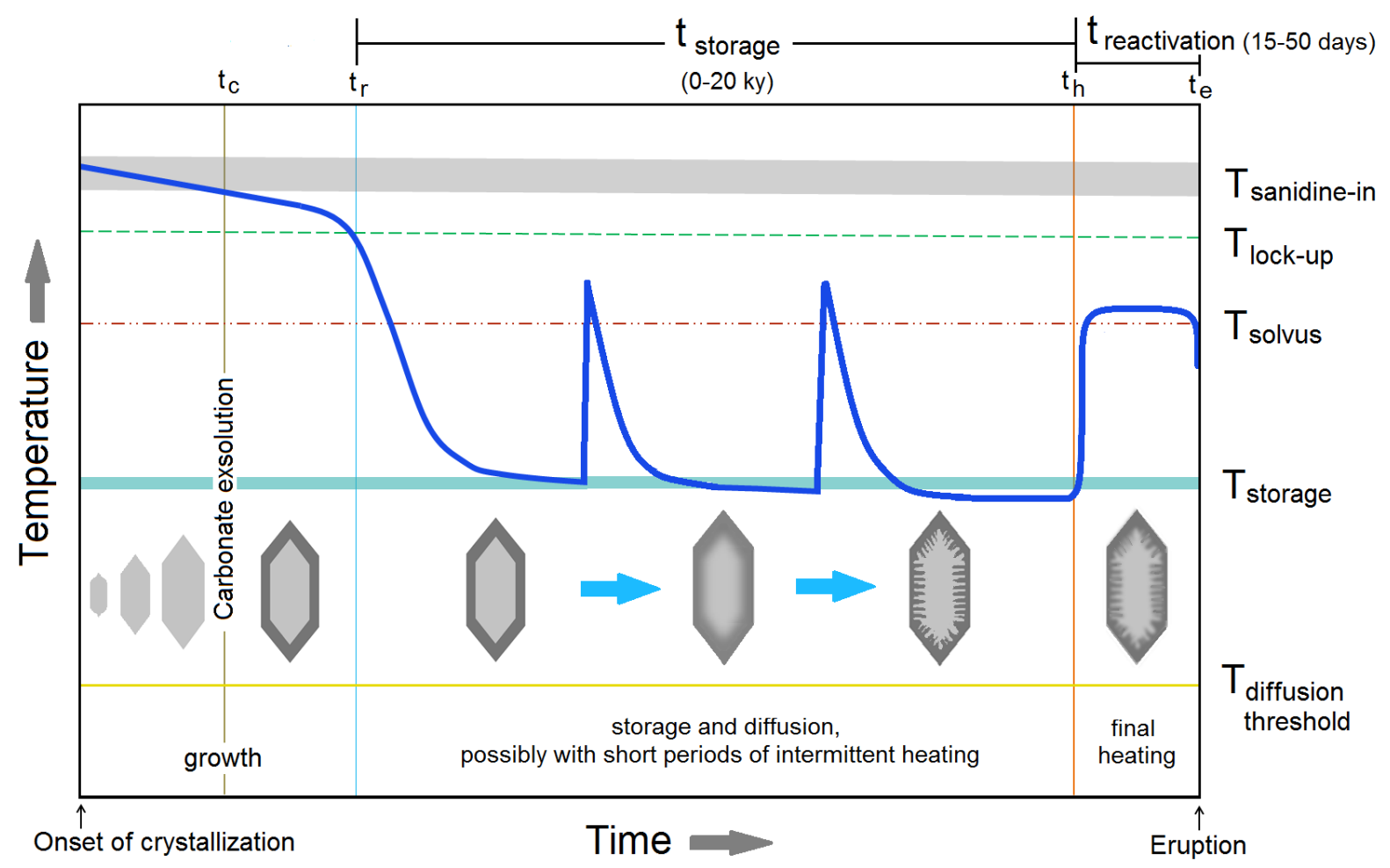

Fig. 7 Schematic diagram summarizing the thermal history (temperature $(T)$ vs time $(t)$ ) of the Laacher See carbonatitic syenites.

In summary (Fig. 7), based on the zircon age data and our estimates for temperatures and diffusion time scales obtained from growth zones and exsolution boundaries in sanidines, we argue that the syenite carapace has resided for most of its storage time at low average temperatures of 630 to $670{ }^{\circ} \mathrm{C}$ ("cold-storage") for several to ten thousand years. Variable temperatures may reflect relative position between the colder country rocks and the hot and still liquid core of phonolite magma. Intermittent episodes of higher temperatures cannot be excluded, but must have been short to maintain the overall low effective temperatures. In this context, higher effective temperature also could reflect more frequent (but still rare) highTemperature episodes rather than a position closer to the hot core.

Based on these constraints and arguments, the following subchapter develops further the temperature-time history of the Laacher See magma system. 


\subsubsection{A Residence History Model: cold versus hot crystal mush}

To develop a model for the residence history of the carbonatite-bearing Laacher See syenites and cumulates, our approach uses petrographic evidence from the crystallization sequence, estimates for the time of crystal growth, as well as temperatures of storage and reactivation as outlined above. The crystal growth duration is constrained by crystal growth rates and the maximum size of crystals ( $\sim 3.5 \mathrm{~mm}$ in the largest dimension). From the minimum effective sanidine growth rates of $1 \mu \mathrm{m}$ per year (Morgan et al. 2003), the maximum growth period of such a crystal is estimated to be $\sim 3500$ years. This is the maximum duration that a typical sanidine crystal has spent between the liquidus or sanidine-in $\left(\sim 750{ }^{\circ} \mathrm{C}\right.$, Harms et al. 2004) and the end of sanidine crystallization.

However, the growth was split into two generations of crystal growth which are evident from the petrographical and compositional variation across sanidine and nosean grains. This, as we have argued above, was most probably the result of carbonatite melt unmixing from a phonolite melt at a temperature of $\sim 750{ }^{\circ} \mathrm{C}$ (Brooker and Kjarsgaard 2010; Kjarsgaard et al. 1995) as discussed above.

After the unmixing of the carbonatite melt, the assemblage was stored at temperature between 630 and $670{ }^{\circ} \mathrm{C}$ which is lower than the temperature at the liquid core of the phonolite magma reservoir. This indicates that the crystal-rich carapace must have been cooling towards the country rock during this time. The temperature may not be maintained at these low values for the entire period, but these values represent the average temperature of storage and diffusive equilibration across the core-rim boundary. Petrographic evidence such as the presence of interstitial glass in equilibrium with clearly faceted crystals (supplementary material 1) suggests that the rocks never cooled completely below their solidus, but the actual solidus is unknown. In fact, no experimental evidence exists to constrain the solidus for such melts with total of $>17 \mathrm{wt} \%$ alkalies, $3 \%$ water between 0.1 and $0.6 \% \mathrm{Cl}$ (data from microprobe analysis of interstitial glasses, Liebsch 1996). The presence of such interstitial glass in equilibrium with crystals, however, suggests that the syenites never had completely solidified and we argue that interstitial glass at temperatures of 630 to $670{ }^{\circ} \mathrm{C}$ should be residual rather than that related to reheating and melting at a later stage. The trace element composition of interstitial glasses (rich in incompatible elements, poor in $\mathrm{Ba}, \mathrm{Sr}$ ) also indicates a highly fractionated melt composition rather than a re-melt of a sanidine-rich mush. Thus, cumulate re-melting, although an often favoured process for magma-mushes of all sizes, settings and compositions 
(Wolff et al. 2015; Bachmann and Bergantz 2008), is not a viable interpretation for these glasses. Our estimated average storage temperature values then indicate that the system and the crystals spent most of the residence time just above the solidus temperature, which by implication of the diffusion evidence, must be less than $630^{\circ} \mathrm{C}$. However, if the syenites were stored as completely solidified rocks below the solidus or even below the diffusion threshold $\left(550^{\circ} \mathrm{C}\right)$ for a major part of the storage time, then we would observe much shorter diffusion lengths for the core-rim gradients as are allowed by the known U-Th zircon ages. Any storage below the diffusion threshold would have to be compensated by time spent at much higher temperatures to explain the observed diffusion gradients within the known storage time and to overcome the latent heat of fusions. This would also have resulted in re-melting to be followed by crystallization for which we see no petrographic evidence from mineral zoning textures. From these arguments, we conclude that these rocks spend the major part of their storage (up to $20 \mathrm{ka}$ ) as a highly crystalline crystal mush with persistent interstitial melt.

Such a model is consistent with many recent studies that propose a long-term cold storage of crystal mushes at low near-solidus temperatures (e.g. Bachmann and Bergantz 2008; Reid 2008, Cooper and Kent 2014, Rubin et al. 2017). These models also suggest that crystal mush storage can end by rapid thermal mobilization by recharging magma that entrain these older crystals (Bachmann and Bergantz 2008; Cooper and Kent 2014). The presence of older crystals in aphyric evolved phonolite are indeed observed: disturbance of U-Th mineral isochrones, crystals akin petrographically to syenitic sanidines, "old" zircons (Bourdon et al. 1994; Ginibre et al. 2007; Schmitt 2006), but we interpret these as accidental xenocrysts entrained during the physical disintegration of the crystal-rich carapace and cumulate bodies rather than remnants after excessive melting to produce the nearly crystal-free phonolite.

A short reheating event of the crystal rich carapace of the Laacher See magma system is, however, evident from the exsolutions in the sanidines and time-scales estimated from their compositional gradients. This indicates that temperatures were raised from "cooler" average residence temperatures of $630-670{ }^{\circ} \mathrm{C}$ where exsolution lamellae formed to a value higher than the feldspar solvus $\left(\sim 712-725^{\circ} \mathrm{C}\right)$ for a maximum of 15 to 50 days prior to eruption. We interpret this (last) short heating event to be associated with the final disintegration of the syenite carapace immediately prior and during the eruption. However, we can only speculate what process in detail may be responsible for this short reheating and eruption triggering event. Basanite magma intruded the magma chamber and mixed and mingled with the mafic phonolitic composition of the ULST and abundant cumulate crystals (Wörner and Wright 
1984). These authors also argue that the mixing event occurred shortly (days) before and during the eruption. Alternatively, the mafic magma may have underplated, intruded and heated the mush pile well (weeks) before the eruption but mixing occurred only during the violent eruption process within a few days of eruption.

Our approach to fix the "effective" diffusion temperature $\left(630-670{ }^{\circ} \mathrm{C}\right)$ for the known crystal age and the Na-K diffusion between core and rim allows further constraints on the earlier thermal history over several thousands of years. Short heating events during this storage cannot be excluded from our data. However, if there were intermittent heating events of longer duration, these would have to be "compensated" by similar times that the crystals must have spent at a very low temperature i.e. below the solidus. However, as we have argued above, sub-solidus conditions are unlikely. Any longer intermittent heating events would also result in much higher temperature variations $\left(550\right.$ to $\left.750{ }^{\circ} \mathrm{C}\right)$ than are recorded in the petrography. Thus, short heating events are allowed and cannot be excluded (but are certainly not required by the observations) and these would imply that intermediate periods would have had only slightly lower $\mathrm{T}$ to compensate for such short high-T episodes. We conclude from these arguments that earlier heating events during storage that lasted over up to $10 \mathrm{ky}$ must have been limited in time (days or weeks) or may not even have occurred at all. A more extensive, long heating event is inconsistent with our observations and long-term storage temperatures were probably rather constant at 630 to $670{ }^{\circ} \mathrm{C}$.

Are our interpretations consistent with the model proposed by Wolff et al. (2015) that suggests thermal rejuvenation of cognate cumulate mush from heating by invading mafic magma with little mass transfer also for the Laacher See case? Their model suggests that heating can result in melting of the cumulate mush to produce water-poor evolved melt that pools along the interface between the mush and the overlying liquid core to produce a chemically zoned magma body. The Laacher See Tephra is a perfect example for such a compositionally zoned magma body. However, the syenites do not possess any petrographic evidence of melting. Rather the syenites were maintained at around eutectic temperatures of 630 to $670^{\circ} \mathrm{C}$ and any interstitial melt (glass) is texturally in equilibrium with the crystals. Although the exsolution and the diffusion time scales provide evidence for a very short thermal event in the syenites within a few years to tens of days before the eruption, we do not see evidence for prolonged high temperatures prior to eruption that would be needed to remelt cumulates and form the compositionally zoned phonolite magma, as proposed by Wolff et al. (2015). 
Based on the discussion above, Fig. 7 summarizes our model and the thermal evolution of the Laacher See magma chamber and its syenite carapace as follows: The model begins at the outset of sanidine crystal growth and ceases at eruption. The formation of core starts at $\mathrm{t}=0$ and $\mathrm{T}=\mathrm{T}_{\text {sanidien-in, }}$ where $\mathrm{T}_{\text {sanidien-in }}$ denotes sanidine liquidus $\left(\sim 760^{\circ} \mathrm{C}\right)$. At time $\mathrm{t}_{\mathrm{c}}$ carbonate unmixes from the silicate melt and the rim starts to form from the residual silicate melt. At $\mathrm{t}=\mathrm{t}_{\mathrm{r}}$, the crystals reach the rheological lock-up temperature $\left(\mathrm{T}_{\text {lock-up, }} \sim 750{ }^{\circ} \mathrm{C}\right)$ and segregate as a rigid mush from the liquid-dominant body. The mush undergoes cooling until the temperature drops to near-solidus temperature. The crystal mush is stored at $\sim T_{\text {storage }}$ (estimated to be $\sim 630-670{ }^{\circ} \mathrm{C}$ ) surrounding the liquid-rich core until $\mathrm{t}=\mathrm{t}_{\mathrm{h}}$, when the heating starts to remobilize the system. During the entire period of storage, the temperature was above the diffusion threshold ( $\mathrm{T}_{\text {diffusion threshold, }} \sim 550{ }^{\circ} \mathrm{C}$ ) for $\mathrm{K}-\mathrm{Na}$ interdiffusion to continue. After remobilization at $\mathrm{t}=\mathrm{t}_{\mathrm{h}}$, the temperature is elevated above $\mathrm{T}_{\text {solvus }}\left(\sim 712-725{ }^{\circ} \mathrm{C}\right)$ and the exsolution in the sanidines start to homogenize until the eruption $\left(t=t_{e}\right) . t_{s t o r a g e}$ is the duration of storage $\left(t_{h}-t_{r}\right)$ estimated to be 0-20,000 years from the absolute ages given by Schmitt et al. 2010. $t_{\text {reactivation is }}$ the interval of remobilization $\left(t_{e}-t_{h}, \sim 15-50\right.$ days) before eruption. The storage allows for short periods of intermittent heating event followed by cooling.

\subsubsection{Relations between liquid core and crystal-rich carapace and cumulates}

Our data documents a range of Na-K diffusion lengths (and thus temperatures) in zoned sanidine crystals for rocks of similar age and this directly implies variable average storage temperatures (Table 1). This implies thermal variation across a mostly crystalline margin surrounding a high temperature magmatic core (Rubin et al. 2017; Annen 2009; Annen et al. 2015; Gelman et al. 2013; Caricchi et al. 2014). Apart from older syenite rocks, the ages of some cumulates, some syenites and those of most phenocrysts from the largely molten phonolite core are very near ( 0-300 years) to eruption age (Bourdon et al. 1994; Schmitt et al. 2006, 2010). This means crystallization of phenocrysts, syenites and formation of cumulates continued up until the eruption. This is in accordance with the conclusion of Harms et al. (2004) from comparing composition and abundances of phenocryst to experimental data that the erupted phonolite magma was just below its liquidus temperature. However, there is no petrographic or compositional evidence for frequent mafic recharge and mixing of new mafic magma into the slowly cooling molten phonolite core (Wörner and Schmincke 1984a, b; Ginibre et al. 2004). The process that formed the compositional zonation across the 
Laacher See magma chamber (Wörner and Schmincke 1984a, b) is only related to differentiation and mixing of variably evolved phonolite magmas and their crystal cumulates (Wörner and Schmincke 1984a, b; Tait et al. 1989; Harms et al. 2004). As argued before, the influx of a mafic basanite magma finally did occur, however, only within days of the eruption.

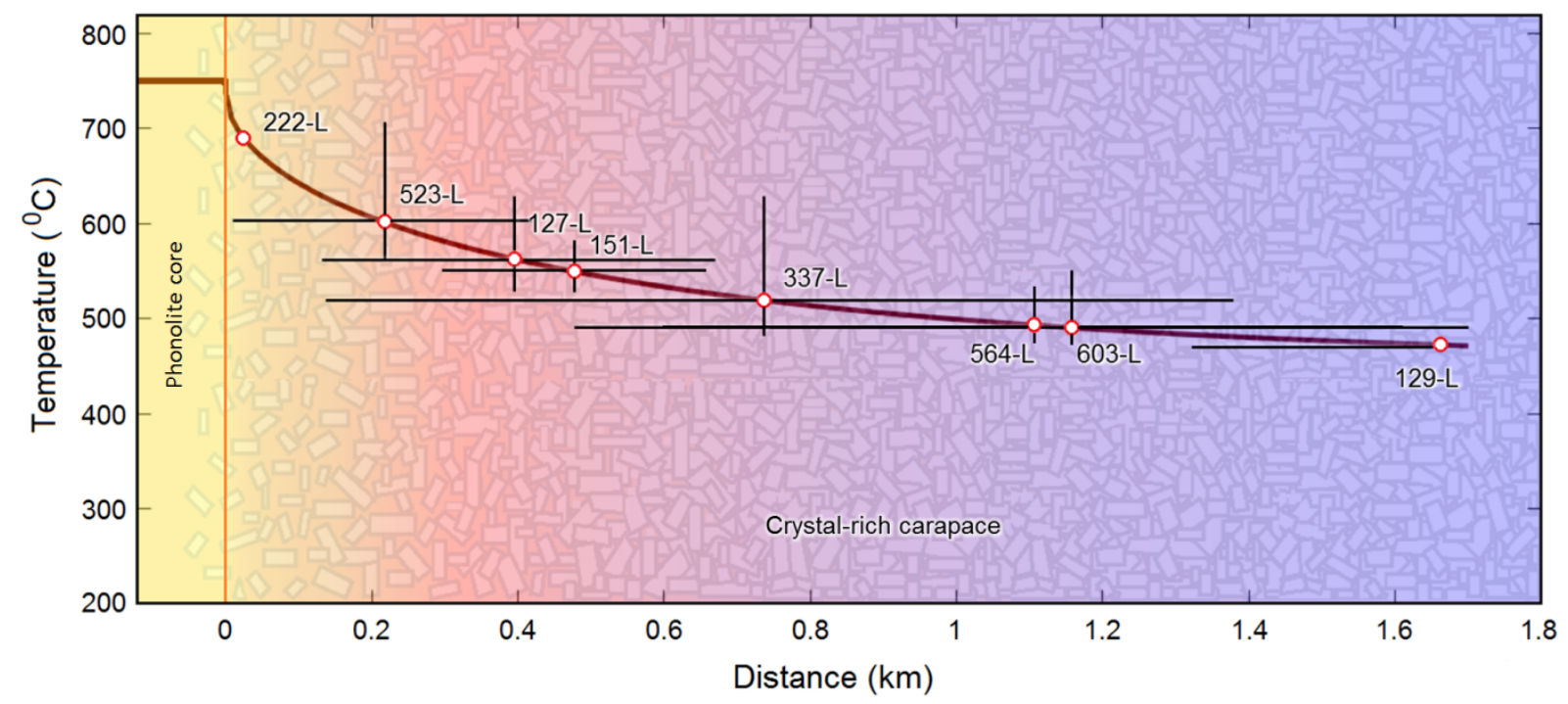

Fig. 8 Variation of temperature across the carbonate-silicate carapace with varying radial distance from the liquid-dominated phonolite core at the time of eruption (after $20 \mathrm{ky}$ long crystallization). Different samples are placed as per their positions (calculated using absolute ages from Schmitt et al. 2010 and Wetzel et al. 2010) at the time of eruption (12.9 ka) w.r.t. the liquid-rich core as estimated from the model. The calculations are done with an assumption of $450{ }^{\circ} \mathrm{C}$ as the initial temperature surrounding country rock.

The Laacher See magma chamber is a good example of an isolated, small, persistent, dominantly liquid, hot magma core inside a colder mush body where only a fraction of the magma chamber is largely liquid (maintained at $\sim 750-760{ }^{\circ} \mathrm{C}$ ) surrounded by a crystal mush stored at near-solidus condition (Rubin et al. 2017). However, in general, the size and life time of such a hot liquid core would strongly depend on the frequency and amount of recharge. Following our discussion above, we argue that recharge and associated heating events probably occur rarely if at all and the liquid core will be relatively small compared to the surrounding crystal-rich carapace. As a result of heat loss, degassing and continuous crystallization, the crystal mush will grow radially inwards making the liquid core gradually shrink with time until volatile saturation is reached and magma buoyancy finally triggered eruption.

The range of estimated temperature values and ages suggests a temperature gradient across the crystal-rich carapace. The storage temperature for a particular crystal should decrease with 
the distance from a slowly shrinking liquid-core (Rubin et al. 2017; Aravena et al. 2017; Philpotts and Ague 2009). Using this hypothesis, we tried to constrain the temperature gradient across the crystal mush. For a crystal-rich mush stored at near solidus temperature, the dominant mode of heat transport is through conduction. We applied a simple conduction model to the crystal mush that surrounds an isothermal liquid core. If the shrinkage rate of the liquid core is $\mathrm{v}$, then distance of a crystal from the interface between the liquid core and crystal mush will be given by vt; where $t$ is the time. And the temperature $(\mathrm{T})$ at any particular position at a given time $t$ will be denoted as

$$
T=T_{S}+\left(T_{L}-T_{S}\right) \operatorname{erf} \mathrm{c}\left(\frac{v \sqrt{t}}{\sqrt{4 D_{T}}}\right)
$$

Where $T_{S}$ is the temperature at the contact to the country rocks, $T_{L}$ is the temperature of the liquid core $\left(\sim 750{ }^{\circ} \mathrm{C}\right)$ and $\mathrm{D}_{\mathrm{T}}$ is the thermal diffusivity. At $\mathrm{t}=0$, the crystal is assumed to cross the lock-up temperature $\left(\sim 750{ }^{\circ} \mathrm{C}\right.$, Cooper and Kent 2014) below which the magma will be a non-eruptible rigid mush. $\mathrm{D}_{\mathrm{T}}$ is taken as the composite diffusivity calculated based on Robertson (1988) using the diffusivity values of sanidine (Höfer and Schilling 2002), sodalite (Hofmeister and Ke 2015), carbonate (Robertson 1988) and silicate melt (Whittington et al. 2009) for a temperature range of $600-700{ }^{\circ} \mathrm{C}$ (see supplementary material 9 ). The chemical diffusion coefficient, in this case, will vary with temperature following the Arrhenius equation i.e. $D=D_{0} e^{-E_{A} / R T}$ and $\mathrm{D}$ should satisfy the condition that $\int_{0}^{t} D d t=D_{e f f} t$ (Wilson, 1970); where $\mathrm{D}_{\text {eff }}$ is the effective diffusivity for the entire duration of chemical diffusion.

We used the above condition to estimate $\mathrm{v}$ through computational modeling using initial temperature values of 200,450 and $600{ }^{\circ} \mathrm{C}$ for the surrounding country rocks. The lower limit of the country rock temperature was taken as $200{ }^{\circ} \mathrm{C}$ based on a normal geothermal gradient and the depth of the magma reservoir (4 to $6 \mathrm{~km})$. The upper limit $\left(600{ }^{\circ} \mathrm{C}\right)$ is taken from the lower limit of estimated storage temperatures. An intermediate temperature of $450{ }^{\circ} \mathrm{C}$ corresponds to the conductive model of Philpotts and Ague (2009). The average shrinkage rate (v) was estimated to be 4.6, 8.4 and $22 \mathrm{~cm} /$ year for country rock temperatures of 200, 450 and $600{ }^{\circ} \mathrm{C}$, respectively. All samples yielded similar values of v. The model by Schmitt et al. (2010) and Ginibre et al. (2004) depicts the syenite-carbonatite carapace surrounding the upper portion of the Laacher See magma chamber. Therefore, we assume a very simplified model of a hemispherical shape for the carapace. Assuming a liquid-rich core of zero size (the 
minimum possible volume), and a constant maximum shrinkage rate of $22 \mathrm{~cm} /$ year (i.e country rock temperature of $600{ }^{\circ} \mathrm{C}$ ) would give a carapace volume of $176 \mathrm{~km}^{3}$. This is unreasonably large compared to the minimum total volume of the evolved portion of the Laacher See magma chamber that was estimated by major and trace element mass balance modeling (16.6 km³, Wörner and Schmincke 1984b). At the opposite end, a country rock temperature of only $200{ }^{\circ} \mathrm{C}$ ( $4.6 \mathrm{~cm} /$ year cooling rate $)$ would imply storage temperature well below the diffusion-threshold which is inconsistent with the width of diffusion profiles observed. An intermediate temperature of $\sim 450{ }^{\circ} \mathrm{C}$ for the surrounding country rocks would indicate a minimum carapace volume of $\sim 10 \mathrm{~km}^{3}$, which is close to the volume estimated for the amount of fractionated minerals to explain the zoned magma. This estimate can now be used to calculate the distance of samples within the carapace from the liquid phonolite core of the magma system that remains close to liquidus temperatures (Fig. 8). This situation may be particularly appropriate for small but long-lived evolved magma systems where the "cold storage" dominates the cooling history of the crystal-rich carapace while the liquid core remains at "hot storage". Such a magma system will not need a strong thermal or mechanical trigger to destabilize and erupt. 


\subsection{Conclusion}

The storage time for the carbonatitic syenites varies from $0-20,000$ years depending on the sample, which also implies 20,000 years of magmatic differentiation until eruption of the Laacher See magma chamber as previously documented by Schmitt et al. (2010).

Our model allows constraints on the temperature history of the long-lived largely liquid hot magmatic body and its slowly cooling near-solidus crystal mush that formed the syenites. The crystal mush surrounded the hot liquid magmatic core which may have been maintained at a near-solidus temperature by recharge of hotter magma (Gelman et al. 2013; Huber et al. 2012; Annen et al. 2008). However, this recharge in the case of the Laacher See magma chamber was probably infrequent (or of low volume) and did not imprint any compositional variations on the magma reservoir or cause advanced re-melting of the crystal mush. Our analysis reinforces the idea of long-term cold storage of crystals surrounding evolved magma reservoirs (Cooper and Kent 2014; Rubin et al. 2017). In such a case, eruptions are generally considered to be triggered by intrusion, reheating, and reactivation of resident magma and the surrounding crystal mush, which can be very rapid (Bergantz et al. 2015; Schleicher et al. 2016). In the Laacher See case, the eruption was also preceded by the invasion of a new basanite magma from the mantle. This basanite magma probably triggered thermal rejuvenation a few years prior to eruption. With or without mixing, advanced differentiation and reduction of density by degassing of the evolved phonolite had occurred prior to eruption within the highly evolved liquid core. This caused the gravitational destabilization of the magma system, followed by physical mixing and mingling of basanite, resident phonolite and crystal cumulates only days before or during the eruption 12,900 ky ago.

Acknowledgements: This study is a part of the doctoral research project funded by Deutscher Akademischer Austauschdienst (DAAD). We thank B. C. Schmidt for discussions and A. Kronz for his support during microprobe analysis. We also thank K. Simon and S. Wu for their assistance during LA-ICPMS measurements. We are grateful to R. S. Iovine and S Fanara for suggestions about diffusion modeling. We appreciate the effort of R. Abart and an anonymous reviewer and thank for their suggestions and comments which helped improving the manuscript. 


\subsection{References}

Annen C (2009) From plutons to magma chambers: thermal constraints on the accumulation of eruptible silicic magma in the upper crust. Earth Planet Sci Lett 284:409-416.

Annen C, Blundy JD, Leuthold J, Sparks RSJ (2015) Construction and evolution of igneous bodies: towards an integrated perspective of crustal magmatism. Lithos 230:206-221.

Annen C, Pichavant M, Bachmann O, Burgisser A (2008) Conditions for the growth of a long-lived shallow crustal magma chamber below Mount Pelee volcano (Martinique, Lesser Antilles Arc). J Geophys Res 113, B07209, http://dx.doi.org/10.1029/2007JB005049

Aravena A, Gutiérrez FJ, Parada MA et al (2017) Compositional zonation of the shallow La Gloria pluton (Central Chile) by late-stage extraction/redistribution of residual melts by channelization: Numerical modelling. Lithos 284-285:578-587.

Baales M, Jöris O, Street M et al (2002) Impact of the late glacial eruption of the Laacher See volcano, Central Rhineland, Germany. Quaternary Research 58:273-288.

Bachmann O, Bergantz GW (2008) Rhyolites and their source mushes across tectonic settings. J Petrol 49:2277-2285.

Barboni M, Boehnke P, Schmitt AK et al (2016) Warm storage for arc magmas. Proc. Natl. Acad. Sci. U.S.A. 113:13959-13964.

Bergantz GW, Schleicher JM, Burgisser A (2015) Open-system dynamics and mixing in magma mushes. Nat Geosci 8:793-796.

Berndt J, Holtz F, Koepke J (2001) Experimental constraints on storage conditions in the chemically zoned phonolitic magma chamber of the Laacher See Volcano. Contrib Mineral Petrol 140:469-486.

Bogaard PJF, Wörner G (2003) Petrogenesis of basanitic to tholeitic volcanic rocks from the Miocene Vogelsberg, Central Germany. J Petrol 44:569-602.

Bogaard vdC, Bogaard vdP, Schmincke HU (1989a) Quartärgeologisch-tephrostratigraphische Neuaufnahme und Interpretation des Pleistozänprofils Kärlich. Eiszeitalter und Gegenwart 39:62-86.

Bogaard vdP (1995) 40Ar/39Ar ages of sanidine phenocrysts from Laacher See tephra (12,900 yr BP); chronostratigraphic and petrological significance. Earth Planet Sci Lett 133:163-174.

Bogaard vdP, Hall CM, Schmincke HU, York D (1989b) Precise single-grain 40Ar/39Ar dating of a cold to warm climate transition in Central Europe. Nature 342:523-525.

Bogaard vdP, Schmincke HU (1984) The eruptive center of the late Quaternary Laacher See tephra. Geologische Rundschau 73:933-980.

Bogaard vdP, Schmincke HU (1990) Vulkanologische Karte der Osteifel (Maßtab 1:50000). Karlsruhe. 
Bourdon B, Zindler A, Wörner G (1994) Evolution of the Laacher See magma chamber; evidence from SIMS and TIMS measurements of U-Th disequilibria in minerals and glasses. Earth Planet Sci Lett 126:75-90.

Brady JB, Yund RA (1983) Interdiffusion of $\mathrm{K}$ and $\mathrm{Na}$ in alkali feldspars; homogenization experiments. Am Mineral 68:106-111.

Brooker RA, Kjarsgaard BA (2010) Silicate-carbonate liquid immiscibility and phase relations in the system $\mathrm{SiO} 2-\mathrm{Na} 2 \mathrm{O}-\mathrm{A} 12 \mathrm{O} 3-\mathrm{CaO}-\mathrm{CO} 2$ at 0.1-2.5 $\mathrm{GPa}$ with applications to carbonatite genesis. J Petrol 0:1-25.

Brown WL, Parsons I (1989) Alkali feldspars: ordering rates, phase transformations and behaviour diagrams for igneous rocks. Mineralogical magazine 53:25-42.

Caricchi L, Simpson G, Schaltegger U (2014) Zircons reveal magma fluxes in the Earth's crust. Nature 511:457-461

Chakraborty S (2008) Diffusion in solid silicates: a tool to track timescales of processes comes of age. Annu Rev Earth Planet Sci 36:153-190.

Chamberlain KJ, Morgan DJ, Wilson CJN (2014) Timescales of mixing and mobilisation in the Bishop Tuff magma body: perspectives from diffusion chronometry. Contrib Mineral Petrol $167: 1034$

Christofferson R, Yund RA, Tullis J (1983) Inter-diffusion of $\mathrm{K}$ and $\mathrm{Na}$ in alkali feldspars: diffusion couple experiments. Am Mineral 68:1126-1133.

Condomines M, Hemond C, Allegre CJ (1988) U-Th-Ra radioactive disequilibria and magmatic processes. Earth Planet Sci Lett 90:243-262

Cooper KM, Kent AJR (2014) Rapid remobilization of magmatic crystals kept in cold storage. Nature 506:480-483.

Cooper KM, Reid MR, Murrell MT, Clague DA (2001) Crystal and magma residence times at Kilauea Volcano, Hawaii:230Th-226Ra dating of the 1955 east rift eruption. Earth Planet Sci Lett 184:703-718.

Costa F, Chakraborty S (2004) Decadal time gaps between mafic intrusion and silicic eruption obtained from chemical zoning patterns in olivine. Earth Planet Sci Lett 227:517-530.

Costa F, Chakraborty S, Dohmen R (2003) Diffusion coupling between trace and major elements and a model for calculation of magma residence times using plagioclase. Geochim Cosmochim Acta 67:2189-2200.

Costa F, Dungan M (2005) Short time scales of magmatic assimilation from diffusion modeling of multiple elements in olivine. Geology 33:837-840

Costa F, Morgan D (2010) Time constraints from chemical equilibration in magmatic crystals. In: Dosseto A, Turner SP, Van Orman JA (eds) Timescales of magmatic processes: from core to atmosphere. John Wiley \& Sons, Ltd, Chichester, UK. doi: 10.1002/9781444328509.ch7 
Druitt TH, Costa F, Deloule E, Scaillet B (2012) Decadal to monthly timescales of magma transfer and reservoir growth at a caldera volcano. Nature 482:77-80.

Duda A, Schmincke HU (1978) Quaternary basanites, melilitite nephelinites and tephrites from the Laacher See Area, Germany. Neues Jahrbuch für Mineralogie-Abhandlungen 132:1-33.

Ellis BS, Bachmann O, Wolff JA (2014) Cumulate fragments in silicic ignimbrites: The case of the Snake River Plain. Geology 42:431-434.

Engelhaupt B, Schüller W (2015) Mineral Reich Eifel. Christaian Wiese Verlag, München, 340 p.

Gelman SE, Gutierrez FJ, Bachmann O (2013) On the longevity of large upper crustal silicic magma reservoirs. Geology 41:759-762.

Giletti BJ, Shanahan TM (1997) Alkali diffusion in plagioclase feldspar: Chemical Geology 139:3-20.

Ginibre C, Wörner G, Kronz A (2004) Structure and dynamics of the Laacher See magma chamber (Eifel, Germany) from major and trace element zoning in sanidine: a cathodoluminescence and electron microprobe study. J Petrol 45:2197-2223.

Ginibre C, Wörner G, Kronz A (2007) Crystal zoning as an archive for magmatic evolution. Elements 3:261-266.

Girard G, Stix J (2009) Magma recharge and crystal mush rejuvenation associated with early postcollapse upper basin member rhyolites, Yellowstone Caldera, Wyoming. J Petrol 50:20952125 .

Hamilton DL, Bedson P Esson J (1989) The behaviour of trace elements in the evolution of carbonatites. In: Bell K (ed) Carbonatites: Genesis and Evolution. Unwin Hyman, London, pp $405-427$.

Harms E, Gardner JE, Schmincke HU (2004) Phase equilibria of the Lower Laacher See Tephra (East Eifel, Germany): constraints on pre-eruptive storage conditions of a phonolitic magma reservoir. J Volcanol Geotherm Res 134:135-148.

Harms E, Schmincke HU (2000) Volatile composition of the phonolitic Laacher See magma $(12,9000$ yr BP); implications for syn-eruptive degassing of S, F, Cl and H2. Contrib Mineral Petrol 138:84-98.

Hawkesworth CJ, Blake S, Evans P et al (2000) Time scales of crystal fractionation in magma chambers-integrating physical, isotopic and geochemical perspectives. J Petrol 41:991-1006

Hawkesworth C, George R, Turner S, zellmer G (2004) Time scales of magmatic processes. Earth Planet Sci Lett 218:1-16.

Hofmeister AM, Ke R (2015) Heat transport properties of feldspathoids and ANA zeolites as a function of temperature. Phys Chem Minerals 42:693-706.

Höfer M, Schilling FR (2002) Heat transfer in quartz, orthoclase, and sanidine at elevated temperature. Phys Chem Minerals 29:571-584.

Huber C, Bachmann O, Dufek J (2012) Crystal-poor versus crystal-rich ignimbrites: a competition between stirring and reactivation. Geology 40:115-118. 
Iovine RS, Fedele L, Mazzeo FC et al (2017) Timescales of magmatic processes prior to the $\sim 4.7 \mathrm{ka}$ Agnano-Monte Spina eruption (Campi Flegrei caldera, Southern Italy) based on diffusion chronometry from sanidine phenocrysts. Bull Volcanol 79:18.

Jones JH, Walker D, Picket DA, Murrel MT, Beate P (1995) Experimental investigations of the partitioning of $\mathrm{Nb}, \mathrm{Mo}, \mathrm{Ba}, \mathrm{Ce}, \mathrm{Pb}, \mathrm{Ra}, \mathrm{Th}, \mathrm{Pa}$ and $\mathrm{U}$ between immiscible carbonate and silicate liquids. Geochimica et Cosmochimica Acta 59:1307-1320.

Kjarsgaard BA, Hamilton DL, Peterson TD (1995) Peralkaline nephelinite/carbonatite liquid immiscibility: comparison of phase compositions in experiments and natural lavas from Oldoinyo Lengai. Carbonatite Volcanism-Oldoinyo Lengai and the Petrogenesis of Natrocarbonatites, IAVCEI Proceedings in Volcanology 4:163-190.

Liebsch H (1996) Die Genese der Laacher See-Karbonatite. Dissertation, Georg-August Universität, Göttingen.

Martin LHJ, Schmidt MW, Mattson HB, Guenther D (2013) Element partitioning between immischible carbonatite and silicate melts for dry and H2O-bearing systems at 1-3 GPa. J Petrol 54: 2301-2338.

Morgan DJ, Blake S (2006) Magmatic residence times of zoned phenocrysts: introduction and application of the binary element diffusion modelling (BEDM) technique. Contrib Mineral Petrol 151:58-70.

Morgan DJ, Blake S, Rogers NW (2003) Crystallisation rates and residence times of sanidine phenocrysts in the AD 472 (Pollena) eruption of Vesuvius. Geophysical Research Abstracts 5, 09352, European Geophysical Society.

Morgan DJ, Blake S, Rogers NW et al (2004) Time scales of crystal residence and magma chamber volumes from modelling of diffusion profiles in phenocrysts: Vesuvius 1944. Earth Planet Sci Lett 222:933-946.

Morse SA (1970) Alkali feldspars with water at $5 \mathrm{~kb}$ pressure. J Petrol 11:221-251.

Parsons I (1978) Alkali-feldspars: which solvus? Phys Chem Minerals 2: 199-213.

Petrishcheva E, Abart R, Schäffer AK et al (2014) Sodium-potassium interdiffusion in potassium-rich alkali feldspar I: Full diffusivity tensor at $850{ }^{\circ} \mathrm{C}$ : Am J Sci 314:1284-1299.

Philpotts AR, Ague JJ (2009) Principles of igneous and metamorphic Petrology. Cambridge, New York.

Reid MR (2008) How long does it take to supersize an eruption? Elements 4:23-28.

Riley TR, Bailey DK, Harmer RE et al (1999): Isotopic and geochemical investigation of a carbonatite-syenite-phonolite diatreme, West-Eifel (Germany). Mineralogical Magazine 63:615-631.

Robertson EC (1988) Thermal properties of Rocks. United States Department of the Interior Geological Survey, open file report:88-441. 
Rubin AE, Cooper KM, Till CB et al (2017) Rapid cooling and cold storage in a silicic magma reservoir recorded in individual crystals. Science 356:1154-1156.

Schäffer AK, Petrishcheva E, Halber G et al (2014) Sodium-potassium interdiffusion in potassiumrich alkali feldspar II: Composition- and temperature-dependence obtained from cation exchange experiments: Am J Sci 314:1303-1318.

Schleicher JM, Bergantz GW, Breidenthal RE, Burgisser A (2016) Time scales of crystal mixing in magma mushes. Geophys Res Lett 43:1543-1550.

Schmincke HU (2007) The Quaternary volcanic fields of the east and west Eifel (Germany). In: Ritter JRR \& Christensen UR (ed) Mantle Plumes, a Multidisciplinary Approach. Springer, Berlin, pp 241-322.

Schmincke HU (2008) Quaternary volcanism of the east and west Eifel (Central Europe). In: McCann $\mathrm{T}$ (ed) Geology of Central Europe. Geological Society, London, pp 1318-1333.

Schmincke HU, Fisher RV, Waters AC (1973) Antidune and chute and pool structures in the base surge deposits of the Laacher See area, Germany. Sedimentology 20:553-74.

Schmitt AK (2006) Laacher See revisited: High-spatial-resolution zircon dating indicates rapid formation of a zoned magma chamber. Geology 34:597-600.

Schmitt AK (2011) Uranium series accessory crystal dating of magmatic processes. Annu Rev Earth Planet Sci 39:321-349.

Schmitt AK, Wetzel F, Cooper KM, Zou H, Wörner G (2010) Magmatic longevity of Laacher See volcano (Eifel, Germany) indicated by U-Th dating of intrusive carbonatites. J Petrol 51:10531085.

Tait SR (1988) Samples from the crystallising boundary layer of a zoned magma chamber. Contrib Mineral Petrol 100:470-483.

Tait SR, Wörner G, Bogaard vdP, Schmincke HU (1989) Cumulate nodules as evidence for convective fractionation in a phonolite magma chamber. J Volcanol Geotherm Res 37:21-37.

Turner S and Costa F (2007) Measuring timescales of magmatic evolution. Elements 3:267-272.

Veksler IV, Petibon C, Jenner GA et al (1998) Trace element partitioning in immiscible silicatecarbonate liquid systems: an initial experimental study using a centrifuge autoclave. J Petrol 39:2095-2104.

Veksler IV, Dorfman AM, Dulski P (2012) Partitioning of elements between silicate melt and immiscible fluoride, chloride, carbonate, phosphate and sulfate melts, with implications to the origin of natrocarbonatite. Geochimica et Cosmochimica Acta 79:20-40.

Viereck L (1984) Geologische und petrologische Entwicklung des pleistozänen Vulkankomplexes Rieden, Ost-Eifel, Bochumer geol. geotechn. Arbeiten 17.

Wedepohl KH, Baumann A (1999) Central European Cenozoic plume volcanism with OIB characteristics and indications of a lower mantle source. Contrib Mineral Petrol 136:225-239. 
Wetzel F, Schmitt AK, Kronz A, Wörner G (2010) In situ 238U-230Th disequilibrium dating of pyrochlore at sub-millennial precision. American Mineralogist 95:1353-1356.

Whittington AG, Hofmeister A, nabelek PI, Galenas MG, Romine WL (2009) Thermal diffusivity of magmas: implications for heat transport in partially molten zones. American Geophysical Union, Fall Meeting 2009, Abstract T24C-02.

Wilson M, Downes H (1991) Tertiary quaternary extension-related alkaline magmatism in Western and Central Europe. J Petrol 32:811-849

Wilson PR (1970) A solution to the diffusion equation for non isothermal diffusion. Solid-state electronics 13:1311-1313.

Wolff JA, Ellis BS, Ramos FC et al (2015) Remelting of cumulates as a process for producing chemical zoning in silicic tuffs: A comparison of cool, wet and hot, dry rhyolitic magma systems. Lithos 236-237:275-286.

Woolley AR, Kjarsgaard BA (2008) Carbonatite occurrences of the world; map and database. Geological Survey of Canada, Open File Report 5796.

Wörner G (1982) Geochemisch-mineralogische Entwicklung der Laacher See-Magmakammer. PhD thesis, Ruhr-Universität Bochum.

Wörner G, Beusen JM, Duchateau N, Gijbels R, Schmincke HU (1983) Trace element abundances and mineral/melt distribution coefficients in phonolites from the Laacher See Volcano (Germany). Contrib Mineral Petrol 84:152-173.

Wörner G, Schmincke HU (1984a) Mineralogical and chemical zonation of the Laacher See tephra sequence (East Eifel, W. Germany). J Petrol 25:805-835.

Wörner G, Schmincke HU (1984b) Petrogenesis of the zoned Laacher SeeTephra. (East Eifel, W. Germany). J Petrol 25:836-851.

Wörner G, Staudigel H, Zindler A (1985) Isotopic constraints on open system evolution of the Laacher See magma chamber (Eifel, West Germany). Earth Planet Sci Lett 75:37-49.

Wörner G, Viereck L, Plaumann S et al (1988). The quaternary Wehr volcano: a multiphase evolved eruption center in the East Eifel Volcanic Field (FRG). Neues Jahrbuch für Mineralogie, Abhandlungen 159:73-99.

Wörner G, Wright TL (1984) Evidence for magma mixing within the Laacher See magma chamber (East Eifel, Germany). J Volcanol Geotherm Res 22: 301-327.

Wyllie PJ, Tuttle OF (1959) Melting of calcite in the presence of water. American Mineralogist 44:453-459.

Yund RA (1984) Alkali feldspar exsolution: kinetics and dependence on alkali interdiffusion. In: Brown WL (ed) Feldspars and Feldspathoids. NATO ASI Series (Series C: Mathematical and Physical Sciences), vol 137. Springer, Dordrecht, pp 281-315. 
Zellmer GF, Blake S, Vance D, Hawkesworth C, Turner S (1999) Short plagioclase residence times at two island arc volcanoes (Kameni islands, Santorini, and Soufriere, St. Vincent) determined by Sr diffusion systematics. Contrib Mineral Petrol 136:345-357.

Zellmer GF, Clavero JE (2006) Using trace element correlation patterns to decipher a sanidine crystal growth chronology: An example from Taapaca volcano, Central Andes. J Volcanol Geotherm Res 156:291-301.

Zellmer G, Turner S, Hawkesworth C (2000) Timescales of destructive plate margin magmatism: new insights from Santorini, Aegean volcanic arc. Earth Planet Sci Lett 174:265-281. 


\title{
Chapter 3: Constraints on the pre-eruptive magmatic history of Laacher See volcano (Germany): study of different eruption products
}

\author{
Smruti Sourav Rout, Gerhard Wörner
}

Geowissenschaftliches Zentrum, Georg-August-Universität (GZG), Goldschmidtstrasse 1, 37077 Göttingen, Germany

\begin{abstract}
:
We studied Ba-diffusion across zoning patterns of alkali feldspars (1) as phenocrysts in mafic and intermediate phonolite, and (2) from cumulates: two different eruption products from the Laacher See volcano (12.9 ka) in western Germany. The modeled diffusion times suggest recharge events every $\sim 1500-3000$ years before eruption. Phenocrysts from particular samples that come from the very base of the reservoir and are the hybrid between the phonolite and an intruding basanite magma, have additional thin $(2-10 \mu \mathrm{m})$ late-stage Ba-rich overgrowth and give diffusion times of 4-8 years, which is interpreted to be the maximum duration between the most recent recharge by the basanite and eruption. The lack of such overgrowth in samples from other parts of the reservoir suggests that effects of the intrusion were limited only to the base. The cumulates are largely devoid of zoned crystals. Only crystals with resorbed boundaries or very thin overgrowths (a few microns) with very sharp compositional changes imply the activation of cumulates only months before the eruption. Based on the diffusion time-scales and storage temperatures obtained in our previous study, we present a genetic model for the process and timing of storage and activation of the system prior to the gigantic eruption of Laacher See.
\end{abstract}




\subsection{Introduction}

Volcanoes, especially the silicic ones, not only pose serious threat to life, socio-economics and aviation, but also contribute to long-term changes in climate and global temperature (Self and Blake 2008; Robock et al. 2009; Sigl et al. 2015). This makes understanding the innerworkings of silicic volcanoes one of the key objectives in petrology. Constraining innerworkings of silicic volcanoes becomes also important, if the crustal evolution of our planet (or any silicate planetary body in general) were to be understood. Among others, one of the crucial aspects in volcanic studies is the state and duration of storage of magma and its crystals. However, despite the gravity, the understanding of this aspect remains fairly deficient (National Academies of Sciences 2017). Although various studies have explored and developed different chronometric methods in the last two decades to address this issue, they all possess certain adavantages as well as disadvantages over each other. U-series absolute dating, being one of the methods, which robustly constrains timescales of magma storage, transport and evolution (e.g. Zellmer et al. 2000; Hawkesworth et al. 2004; Schmitt et al. 2010 and many others; and intra-crystal dating e.g. Rubin et al. 2016; Cisneros de León 2019a, b and many others; see reviews and examples in Reid 2008; Schmitt 2011; Cooper 2015) lacks temporal resolution. On the other hand, diffusion chronometry (examples include Morgan et al. 2004; Chamberlain et al. 2014; Kahl et al. 2015 and many others) which provides high temporal resolution, suffers from higher degree of uncertainties (Spear 2014; Rout et al. 2019).

Diffusion modeling measures the duration of diffusive homogenization of compositional constrasts formed within the crystal due to changes in growth (or magmatic) conditions (see Costa et al. 2008 and Dohmen et al. 2017 for many examples). However, the rate of diffusion or diffusivity is highly susceptible to temperature (and sometimes moderately by other parameters also e.g. pressure and $\mathrm{H}_{2} \mathrm{O}$-content) (Costa et al. 2008, Spear 2014; Dohmen et al. 2017), which contributes to the maximum uncertainties in calculated durations. Therefore, constraining temperature and the thermal history of magma and its crystals becomes exceedingly important, if storage and evolution time-scales are to be constrained.

When it comes to thermal state of magma storage, contrasting models have been proposed over the years making it a highly debated topic in volcanology (National Academies of Sciences 2017). One model, known as the "warm storage" model (Barboni et al. 2016) states 
that magma is stored as a hot $\left(>750^{\circ} \mathrm{C}\right)$ liquid-rich eruptible state for tens to hundreds of thousands of years (Kaiser et al. 2017). The temperature is maintained by periodic recharges of fresh and hot magma (Gelman et al. 2013, Huber et al. 2012). The other model, known as the "cold storage" model (Cooper and Kent 2014; Rubin et al. 2017), argues that instead, magma is stored as a cold (at near or subsolidus temperature) rigid non-eruptible crystal-rich mush for up to hundreds of thousands of years (Reid 2008; Cooper 2019). This kind of a system needs strong trigger for eruption which would melt the mush to produce an eruptible melt (Bachmann and Bergantz 2008; Girard and Stix 2009; Wolff et al. 2015). There are evidences for both of the models and different chrnonmetric studies have fallen into either of the two catagories. For example, for some systems, the diffusion times obtained for temperatures of more than $750{ }^{\circ} \mathrm{C}$ are limited to only a few hundreds to a few thousands of years, which are very short (by 100 times) compared to the absolute U-series ages (e.g. Cooper and Kent 2014; Rubin et al. 2017). This suggests that the actual temperature of storage was much lower making it case of cold storage. Similarly, for some systems, diffusion times obtained for temperatures as high as $780{ }^{\circ} \mathrm{C}$ are hundreds of thousands of years in magnitude (e.g. Morgan and Blake 2006). This clearly suggests a very long storage at high temperature making it a case of warm storage.

Here, we study the Laacher See volcano in the context of "cold vs warm" storage. We study the pumice and the cognate crystal-rich cumulate ejecta from this phonolitic system. The Laacher See volcano erupted $12.9 \mathrm{ky}$ ago (Baales et al. 2002) and is one of the largest Quaternary eruptions in central Europe. Although the current level of volcanic and magmatic activity in the Eifel volcanic field is assumed to be very low, increased gas flux (Goepel et al. 2015) and deep low-frequency earthquakes at 10-40 km depth are detected underneath Laacher See, suggesting ongoing lower-crustal level magmatic activity (Hensch et al. 2019). This makes this study even more timely as the risk would be huge, in case Laacher See becomes active again in furture, considering the dense population and busy air space in this region (Leder et al. 2017; Hensch et al. 2019).

The Laacher See reservoir has been well studied in terms of chemical stratigraphy, evolution of the resident phonolite and its crystalline equivalent i.e. the cognate crystal-rich cumulate ejecta (e.g. Wörner and Schmincke 1984a, b; Wörner and Wright 1984; Tait et al. 1989; Harms and Schmincke 2000; Schmitt et al. 2010 and others). For some of these rocks, absolute crystal ages have been determined by U-series dating (Bourdon et al. 1994; Schmitt 
et al. 2010) which show that crystallization preceeded eruption by up to $20 \mathrm{ky}$. Here we apply diffusion chronometry to compositional gradients across sanidine crystals from the phonolitic pumice and the phonolitic cumulates to extract information on crystal residence times and the storage conditions of the crystalline cumulate mush ("cold" storage) and the main phonolite body ("warm" storage) prior to eruption.

\subsection{Geology and Petrography}

\subsubsection{Geological setting}

Laacher See (12.9 ka; Baales et al. 2002), situated in the west of Germany, is the youngest and the largest volcano in the East Eifel Volcanic Field (EEVF). It is part of the central European Upper Tertiary to Quaternary intra-plate alkaline volcanism, and is located in the western part of the uplifted Paleozoic Rhenish Massif (Fig. 1) (Schmincke 2007, 2008).

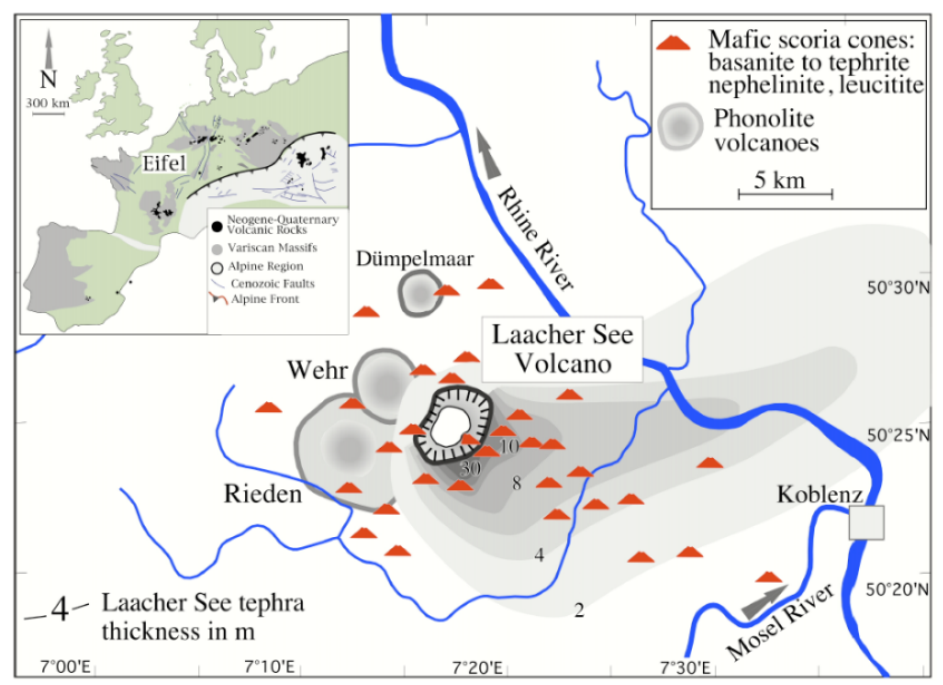

Fig 1. Schematic map of East Eifel volcanic field (from Rout and Wörner 2018) with Laacher See ( 13 ka) in the east and Rieden ( 460-360 ka) and Wehr ( 215 ka) centers in the west and north-west.

The Upper Tertiary to Quaternary magmatism in this region primarily produced mafic magmas with composition ranging from basanite and alkali basalt to quartz tholeiite as small scattered eruption centers or as large shield volcanoes e.g. Vogelsberg $\left(600 \mathrm{~km}^{3}, 15-16 \mathrm{Ma}\right)$ (Wilson and Downes 1991; Wedepohl and Baumann 1999; Bogaard and Wörner 2003). The eruption centers in the EEVF (which are more than 100 in number) produced predominantly 
basanitic, nephelinitic, leucititic and their differentiated magmas over the past $440 \mathrm{ky}$ (Duda and Schmincke 1978; Wörner and Schmincke 1984a; Bogaard et al. 1989a, b; Bogaard and Schmincke 1990; Schmincke 2007). These mafic eruptions produced phreatomagmatic phases at the beginning, with blocky lava flows and individual maars, forming several scoria cones (Schmincke et al. 1973; Schmincke 2007). The oldest and poorly preserved ash deposits date back to 450-650 ka (Bogaard and Schmincke 1990) erupted in the North West of EEVF right before the beginning of evolved volcanism.

The evolved volcanism in EEVF began with the Rieden volcanic complex that produced more than $10 \mathrm{~km}^{3}$ of phonolite and leucitititc tephra 380-430 ka (Viereck 1984; Bogaard et al. 1989a; Bogaard and Schmincke 1990). After Rieden, Wehr volcano erupted phonolite to trachyte and evolved phonolitic tephra $\sim 215$ and $\sim 150 \mathrm{ka}$, respectively (Wörner et al. 1988; Bogaard and Schmincke 1990). The third and the largest evolved volcanic center is the Laacher See, a phonolitic system. The evolution of the phonolitic reservoir began $\sim 30 \mathrm{ka}$ (Schmitt et al., 2010) which ultimately fed the gigantic eruption 12.916 ka (Baales et al. 2002).

The eruption history of EEVF consists of mostly varieties of mantle-derived alkaline magmas with intermittent and rather infrequent production of evolved magmas, which are identified to be the differentiated products of the mafic magams (Duda and Schmincke 1978, Viereck 1984 and Wörner and Schmincke 1984a, b). Advanced crustal assimilation is uncommon and has only been observed in the trachytes from the Wehr volcano (Wörner et al. 1988).

\subsubsection{The Laacher See eruption}

The Laacher See produced $\sim 6.3 \mathrm{~km}^{3}$ DRE of phonolitic magma within a period of days to weeks (Bogaard 1995) whereas the total eruption period may have lasted for several months (Schmincke 2007). The eruption is documented as a major Quaternary tephra marker across central and northern Europe (Bogaard and Schmincke 1989b; Baales et al. 2002). Millimeterscale ash layers are documented at $>1000 \mathrm{~km}$ distance in southern Sweden and northern Italy (Blong et al. 2018; Hensch et al. 2019). Geochemical and experimental studies have estimated the top of the phonolitic reservoir to be at 4-6 km of depth (Wörner 1982; Harms and Schmincke 2000; Berndt et al. 2001; Harms et al. 2004). The Laacher See reservoir is a classic example of a zoned magma reservoir which is evident from its well-stratified and 
zoned tephra deposit (Laacher See tephra or LST)(Wörner et al. 1983; Wörner and Schmincke $1984 \mathrm{a}, \mathrm{b})$. the LST is an inverted representation of the phonolitic reservoir. Thus, the Lower Laacher See Tephra (LLST) characterized by highly differentiated composition and enrichment of incompatible trace elements, is the top of the reservoir. Similarly, the Middle Laacher See Tephra (MLST) is the moderately differentiated and most volumous mid-part of the reservoir while the Upper Laacher See Tephra (ULST) is the least evolved base of the reservoir. The top most part of LST (above ULST) is of a hybrid composition consisting of both mafic minerals like forsteritic olivine and magnesian clinopyroxene, even small mantle peridotite xenoliths, and phonolitic minerals like sanidine, sodic plagioclase, hauyne, amphibole, fassaitic clinopyroxene and titanite, which are typical of MLST and ULST. These hybrids are products of mixing and mingling between the resident phonolite and an intruding mafic basanite magma (Wörner and Wright 1984). It is unclear wheather this mixing was preeruptive (perhaps part of the trigger) or rather syn-eruptive (a by-product of the eruption).

Apart from phonolite, the ULST has a variety of xenoliths in abundance. Partially contactmetamorphosed and fenitized country rock e.g. partially melted Devonian slates, greenschists and rare amphibolite-facies metamorphic lithics dominate the xenolith population. They were incorporated from the thermal aureole around the reservoir during the gravitational destabilization in the final stages of the eruption. The observed thermal metamorphism indicates that the liquid-rich phonolite had continuously supplied heat to the surrounding country rock over its $20 \mathrm{ky}$ long evolution. The results of this heat loss are also evident from the cognate plutonic and cumulate ejecta, which represent the cooling exterior of the reservoir. The cumulates are crystal-rich $(>70 \%)$, and petrographically and texturally very diverse (see sample description for details) indicating a very complex crystallizion history of cumulate carapace that surrounded the Laacher See reservoir (Rout and Wörner 2018).

Apart from the phonolitic cumulates, the ULST also contains, although rarely, highly crystalline cognate carbonatitic syenites. These carbonatites are distinctive in terms of their intrusive nature and presence of interstitial highly differentiated phonolitic glass similar to LLST (Liebsch 1996; Schmitt et al. 2010). Like other cumulates, these rocks are also interpreted to be the fragmented parts of the surrounding crystalline carapace (Tait et al. 1989). Crystals in these rocks share highly faceted idiomorphic boundaries with the interstitial vesicular melt. The interstitial glass, like LLST, is also poor in $\mathrm{Ba}$ and $\mathrm{Sr}$, and highly enriched in incompatible trace elements. These observations suggest against re-melting of the 
carbonatitic syenites to generate the interstitial melt and, instead, suggest a close genetic relation with the main phonolitic magma from the reservoir interior. Rout and Wörner (2018) have studied specifically these carbonatitic syenites and constrained their residence and thermal history. Their study concludes that the syenites were stored as a crystalline mushy carapace for up to $20 \mathrm{ky}$ at $630-670{ }^{\circ} \mathrm{C}$ until the final distabilisation of the system only $15-50$ days before the eruption. In the present study, we analyze sanidines from the major eruption products of the Laacher See volcano: the phonolithc pumice representing the molten core of the magma system and the phonolitic cumulates to fully document the thermal history of the entire Laacher See magma system prior to its eruption.

\subsubsection{Samples and petrography}

\section{Pumice:}

We have investigated feldspars from seven pumice samples that were chosen as representatives from different parts of the deposit (i.e. bottom and the top of the magma chamber).

Detailed mineralogical descriptions of the very samples have been given by Wörner and Schmincke (1984a). The samples (1002) from LLST are mostly white pumice from the very base of the deposit (top of the magma chamber). Phenocrysts are mainly sanidine $(\leq 1 \%)$ but nepheline, plagioclase, haüyne, clinopyroxene, amphibole, titanomagnetite, titanite, apatite, rare zircons and cancrinite also occur. Samples $(1034,1050)$ from the middle and top of the MLST (middle and base of the central part of the magma chamber) are white to light gray pumices. Phenocryst-content varies from rare (1-5\%) to relatively more abundant $(5-15 \%)$, as we go down the magma body. They are mainly feldspars (sanidine and plagioclase), large euhedral haüyne, titanite, apatite, subordinate clinopyroxene, amphibole and titanomagnetite. Clots, $1-3 \mathrm{~cm}$ in size, of a more mafic phonolite with crenular margins, petrographically identical to the more mafic pumice found in these samples and occur in various states of disaggregation. Samples from the ULST $(1060,1088)$ are mafic phonolites from the base of the magma chamber and have a phenocryst content of 30-60\%, mainly feldspars (plagioclase and sanidine), amphibole, clinopyroxene, titanite, apatite and titanomagnetite. There is no evidence for significant mixing with a mafic magma (only few small phlogopite crystals and rare Fo-rich olivines are found in the matrix). Sample 1088-H1, 1088-H3 and 1099 are hybrid 
samples from the top of the deposit (Wörner and Wright, 1984) and contain, in addition to mineral phases similar to those of sample 1088, significant amounts of crystals from the basanitic endmember: olivine, pyroxene megacrysts and phlogopite. Large, resorbed nepheline crystals are also present. Because the feldspar mineralogy is the same as in sample 1088 and represents the mafic phonolitic end-member, we consider both types of samples together as representative of ULST.

Sanidine and plagioclase occur in all the pumice samples studied, with sanidine always being the most abundant phase. Several thin sections of all the samples were investigated, whereas mineral separates were used for samples 1002 and 1034 because of their low crystal contents. In each of the samples, 15-50 sanidine crystals were investigated by optical microscopy and 30 zoned crystals in total were chosen for microprobe analyses.

The sanidine phenocrysts in the samples from LLST, i.e. the most evolved phonolite, are characterized by $65-68 \mathrm{wt} \% \mathrm{SiO}_{2},<0.3 \mathrm{wt} \% \mathrm{CaO}, \sim 0.15-0.47 \mathrm{X}_{\text {Or }}$ and $<100 \mathrm{ppm} \mathrm{Ba}$ and $\mathrm{Sr}$. More than $60 \%$ of the crystals are patchy-zoned in orthoclase-content ( $\left.\mathrm{Or}_{47}-\mathrm{Or}_{15}\right)(\mathrm{Fig} 2 \mathrm{a}, \mathrm{b})$. The zone boundaries are always over printed by exsolution (between the orthoclase- and albite-rich phases). These observations make these sanidine crystals compositionally and texturally identical to the sanidine grains in the carbonatitic syenites analyzed by Schmitt et al. (2010) and Rout and Wörner (2018). Therefore, we interpret these grains to be xenocrysts coming from the overlying crystalline syenitic carapace which were incorporated into the underlying phonolite during the final destabilization of the system (probably weeks before eruption; Rout and Wörner 2018). The resorbed rims of these crystals suggest disequilibrium with the host magma and thus, support this interpretation. 

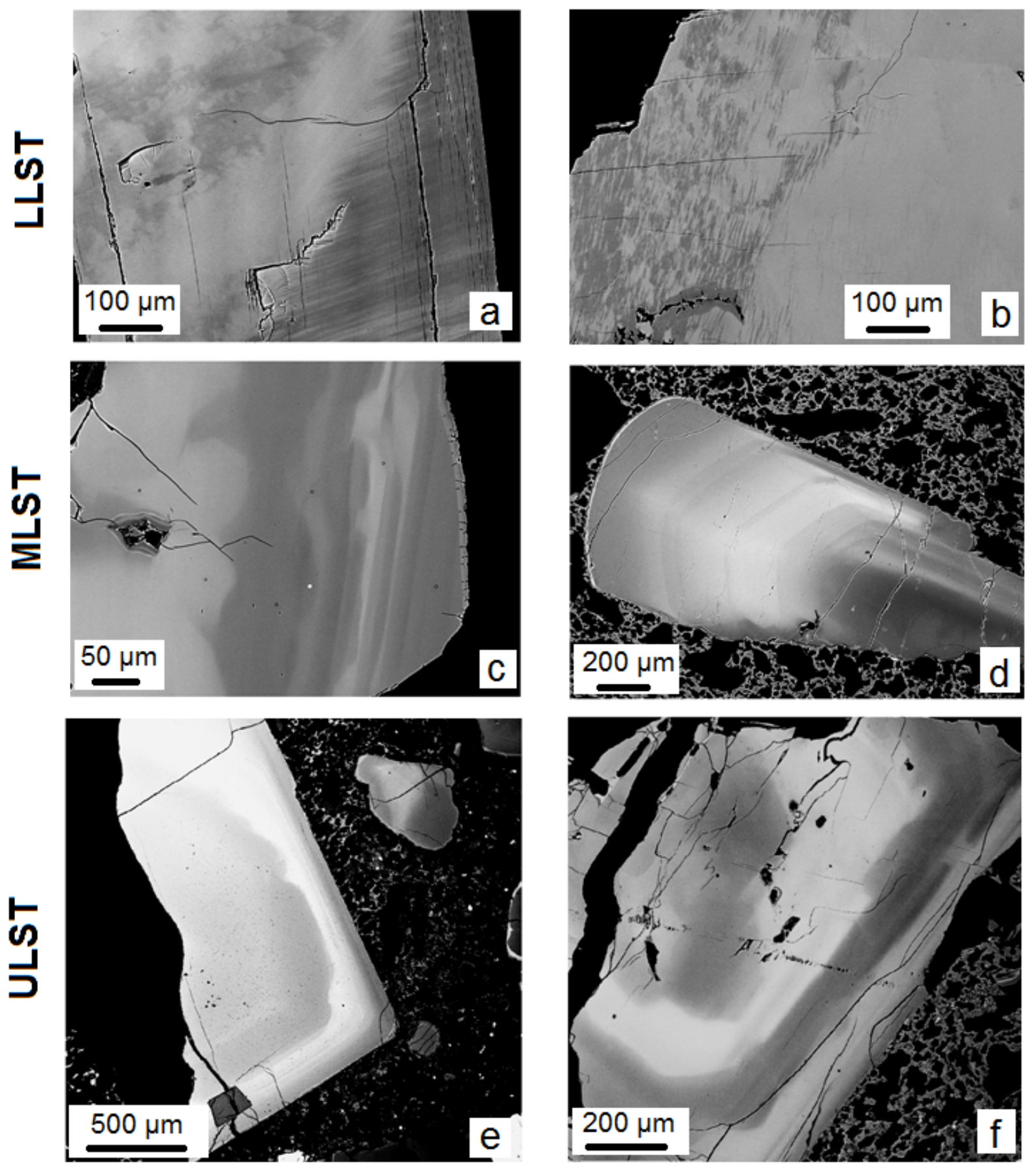

Fig 2. Accumulated backscattered electron images of selected crystals from the three major stratigraphic units of Laacher See Tephra (a \& b: LLST; c \& d: MLST; e \& f: ULST) illustrating the intra-grain compositional and textural features. a-d are from Ginibre (2000). 

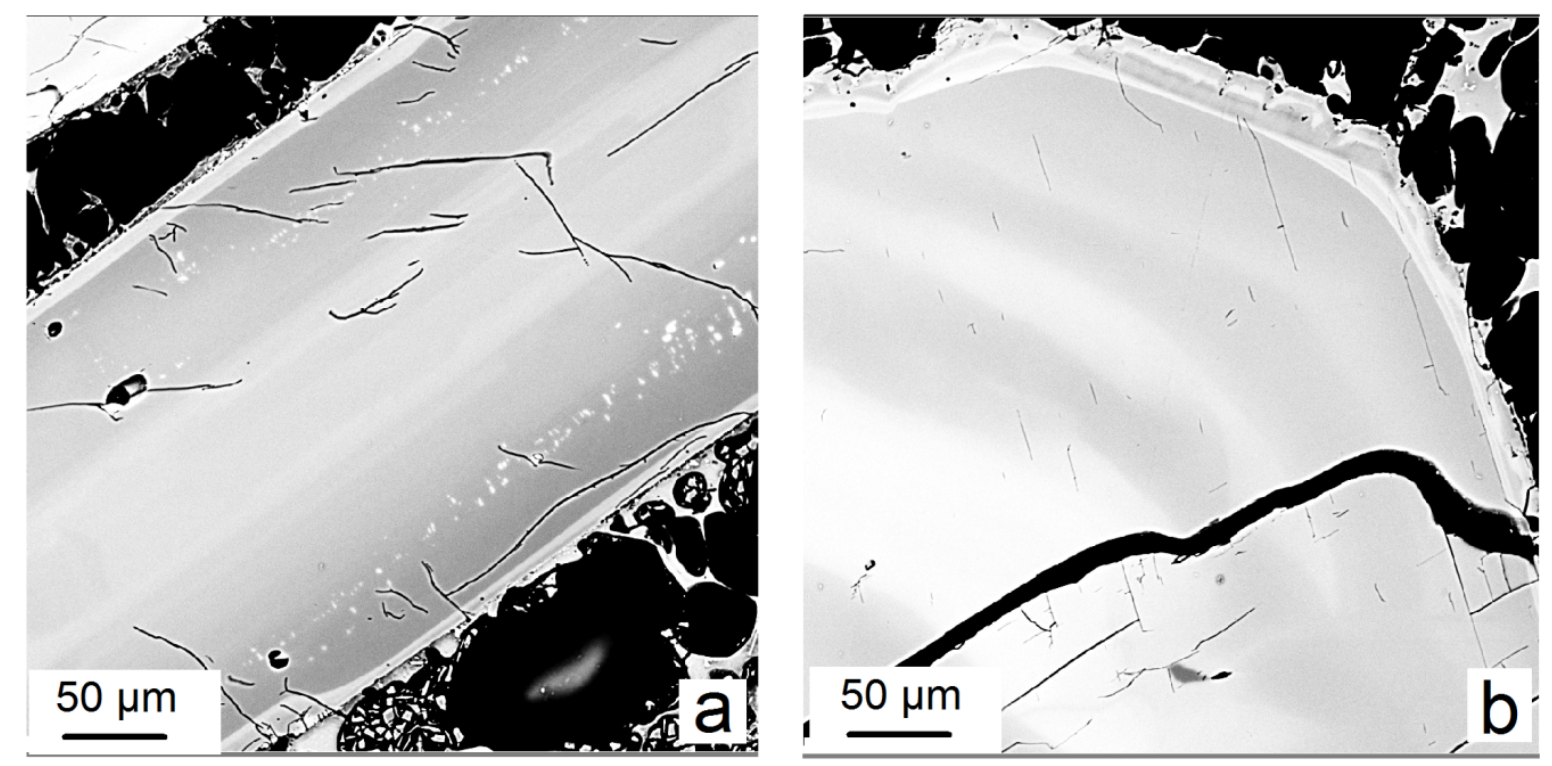

Fig 3. Accumulated backscattered electron images of selected crystals from the hybrid samples (upper ULST). The thin $(<10 \mu \mathrm{m})$ Ba-rich overgrowths (light grey in color) are evident in the crystals.

The sanidine phenocrysts from MLST, are characterized by alternating growth and resorption bands (Fig 2c, d). They have 63-66 wt\% $\mathrm{SiO}_{2}, 0.4-1 \mathrm{wt} \% \mathrm{CaO}$ and $\sim 0.63-0.69 \mathrm{X}$ Or, with Baand Sr-content varying between 0.4 and $1.6 \mathrm{wt} \%$, and 0.1 and $0.4 \mathrm{wt} \%$, respectively, between zonations. Unlike the sanidine phenocrysts from LLST, they are nearly homogenous throughout crystal in terms of major element composition. Thus, the zonation is only due to variation in $\mathrm{Ba}$ and $\mathrm{Sr}$. Each sanidine grain has 2 to 4 significant or well-identifiable zones (characterized by a change of at least $0.5 \mathrm{wt} \%$ in Ba content). Apart from growth bands, the crystals occasionally ( $<5 \%$ of the population) also show oscillatory zonation (Fig $2 \mathrm{~d}$ ). The sanidine phenocrysts from the bottom of the reservoir or ULST (Fig 2e, f) are compositionally very similar to the ones in MLST, but with slightly higher Ba concentration (up to $2.4 \mathrm{wt} \%$ ). Like the sanidines in MLST, the overall composition is primarily the same. An important observation is that the sanidine phenocrysts in the upper ULST samples which are the hybrid between the phonolite and the basanite, have an additional very thin (2-10 $\mu \mathrm{m}$ wide) Ba-rich $(\sim 1.8-2.5 \mathrm{wt} \%)$ overgrowth (Fig 3).

\section{Cumulate:}

Cumulates are the rock fragments that are considerably more crystal-rich than pumice clasts at the same stratigraphic horizon. Tait (1988) and Tait et al. (1989) have shown, on the basis of the petrography and chemical composition of minerals and interstitial glasses, that the 
cumulates are comagmatic with LST, representing the materials crystallizing at the chamber margins prior to eruption.
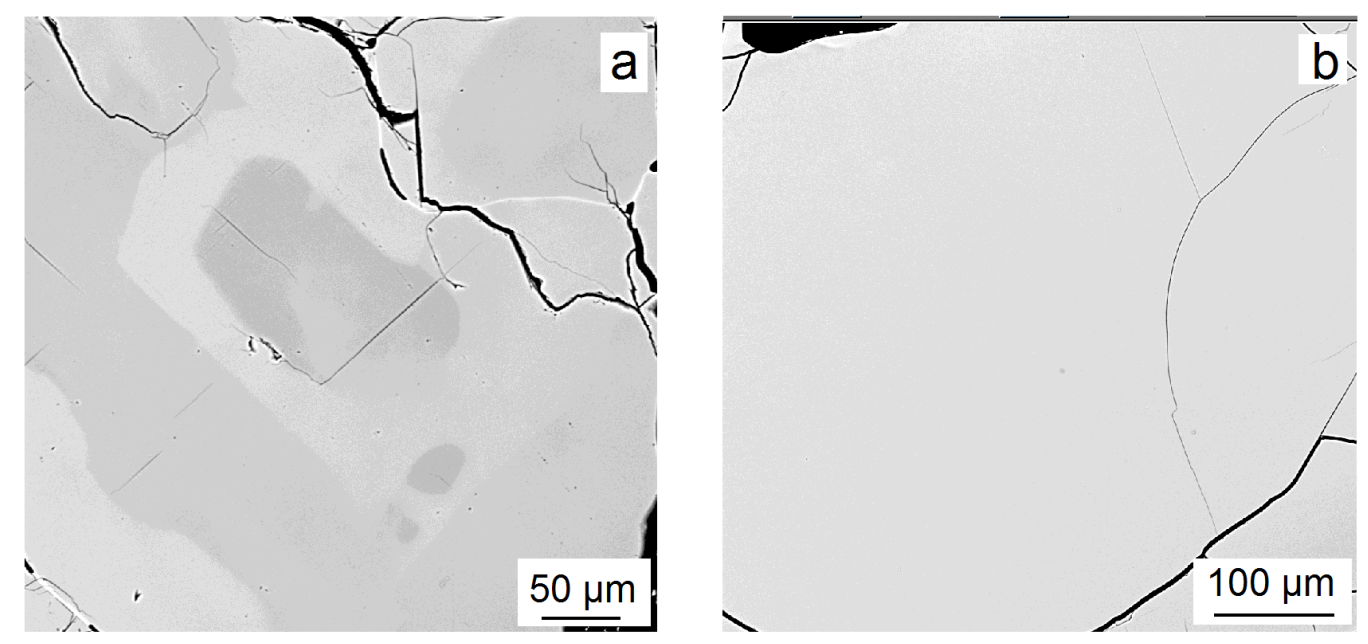

Fig 4. Accumulated backscattered electron images of selected crystals from the cumulates. (a) example of zoned crystal. (b) an example of from the unzoned crystals which are constitute majority ( $>99 \%)$ of the population.

Cumulates typically consist of interlocking crystal frameworks with a glassy matrix. Individual crystals are $0.5-5 \mathrm{~mm}$ in size and sometimes show parallel textures typical of layered cumulate rocks. Mineral assemblages range from mafic to felsic, and interstitial glass contents usually lie between $\sim 1$ and $30 \mathrm{vol} \%$. Mafic samples consist of predominantly clinopyroxene, amphibole, magnetite and apatite with small amounts of feldspar. An average of 7 vol. \% matrix is present with a variable clinopyroxene/amphibole ratio. Intermediate nodules contain between 50 and 80 vol.\% feldspar, the remainder being composed of clinopyroxene, amphibole, apatite, mica and titanite. Among felsic cumulates, syenitic composition is the most common. Sanidine is the only feldspar. Haüyne (10-15 vol\%) and minor amounts of clinopyroxene, amphibole, titanite and magnetite are generally present. Some of the other felsic samples contain sanidine plus a triclinic feldspar which is usually anorthoclase but sometimes lies in the adjacent oligoclase field of the plagioclases (Tait, 1988). Full details of the petrography of cumulates are described in Tait (1988) and Tait et al. (1989). We analyzed a total of 15 samples for petrography and microscopic analysis and chose 6 representative samples ( 2 each from felsic, intermediate and mafic types) for microprobe analysis.

The sanidines in the phonolitic cumulates are compositionally equivalent to their stratigraphic pumice counter-part. The composition of the sanidines in the felsic cumulates 
are similar to those in the LLST and syenites, characterized by $\sim 0.2-0.46 \mathrm{X}_{\mathrm{Or}}$ and extremely low $(<100 \mathrm{ppm}$ ) Ba and Sr concentration. Less than $1 \%$ of the crystals are zoned (Fig. 4). The zonation is mainly patchy with minute exsolution texture. Sanidines in the intermediate and mafic cumulates contain $\sim 0.6-0.7 \mathrm{X}_{\mathrm{Or}}, 0.1-0.5 \mathrm{wt} \% \mathrm{Sr}$ and $0.1-1.8 \mathrm{wt} \% \mathrm{Ba}$, similar to MLST and ULST. Few of the sanidines in all three types of samples, share ragged outlines with surrounding glass (supplementary material 1) and have holes filled with glass suggesting possible resorption and melting. 


\subsection{Analytical methods:}

Quantitative analyses were done at at GZG, Universität Göttingen with a JEOL JXA-8900R microprobe. The measurements were done with a accelerating voltage of $15 \mathrm{kV}$, beam current of $15 \mathrm{nA}$ and beam diameter of $10 \mu \mathrm{m}$. For all the elements other than $\mathrm{Ba}$ and $\mathrm{Sr}$, counting times were $15 \mathrm{sec}$ on the peak and $5 \mathrm{sec}$ on the background. For $\mathrm{Ba}$ and $\mathrm{Sr}$, up to $120 \mathrm{sec}$ on the peak and $60 \mathrm{sec}$ on the background were used but concentrations in the sanidines from the most evolved pumice and cumulates were still below the detection limit (79 and $220 \mathrm{ppm}$ for $\mathrm{Ba}$ and $\mathrm{Sr}$ respectively). Calibration standards used during the measurements were albite for $\mathrm{Na}$, sanidine for $\mathrm{K}$; anorthite for $\mathrm{Si}, \mathrm{Ca}$ and $\mathrm{Al}$; hematite for $\mathrm{Fe}$; $\mathrm{SrTiO}_{3}$ for $\mathrm{Sr}$ and celsian for $\mathrm{Ba}$. The relative standard deviation for all major oxides was $<2 \%$ and the calculated absolute error for the minor oxides was $0.003-0.03 \mathrm{wt} \%$. Accumulated back scattered electron (BSE) images were obtained by superimposing ten BSE image accumulations acquired using map analysis in COMPO mode with $20 \mathrm{kV}$ accelerating voltage and $20 \mathrm{nA}$ beam current and with a slow scanning beam with acquisition time of $120 \mathrm{sec}$ per accumulation (e.g. Fig 2, 3, 4, 5, 6). Compositional profiles across zone boundaries and from crystal core to rim were obtained perpendicular to the zone boundaries while referring to the BSE images. To estimate the lateral spatial resolution of the BSE images, a Monte Carlo simulation was done. The simulation suggests a lateral resolution of $<400 \mathrm{~nm}$ with $95 \%$ of the BS electrons coming from a depth of $<450 \mathrm{~nm}$ with lateral diameter of $<400 \mathrm{~nm}$ (online resource 1). The obtained quantitative data and BSE images for the sanidine phenocrysts in the phonolite and in the cumulate samples are provided in online resource 1 and 2 . The specifics of the obtained results are discussed below. 


\subsection{Results and discussion:}

We focus the discuss on causes of the zoning patterns and correlation between different samples, and linking these to the crystal residence times. The aim is to understand and reconstruct the temperature-time history of the reservoir prior to the eruption.

\subsubsection{The zonation (texture, causes and comparison between samples)}
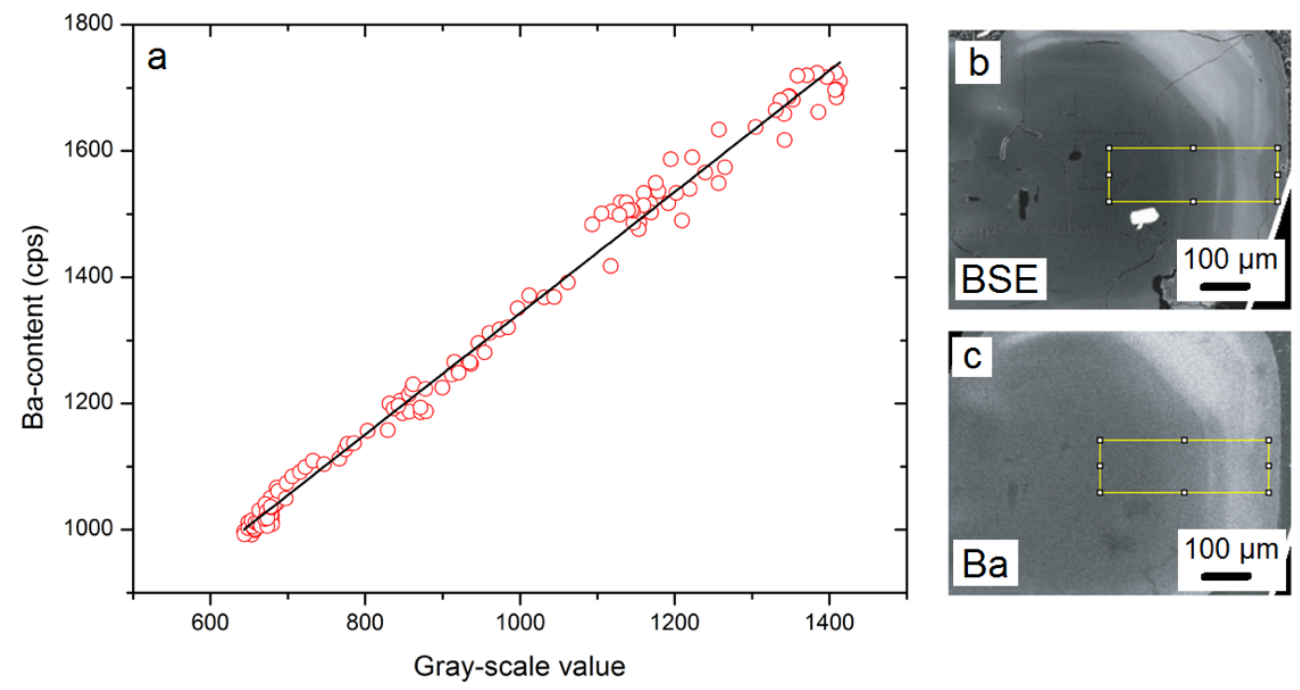

Fig 5. (a) Correlation between Ba-content (cps) and grey-scale values from a selected crystal. The values are obtained using swath profiles (yellow rectangles) in the BSE image (b) and Ba-intensity map (c) (after Ginibre et al. 2004).

The zonation patterns in the sanidine phenocrysts from MLST and ULST samples can be broadly divided into two categories: the frequently occurring growth bands (up to $200 \mu \mathrm{m}$ width; Fig 2c, e \& f) and occasional oscillatory zoning (up to $20 \mu \mathrm{m}$ width, Fig $2 \mathrm{~d}$ ). The growth bands often consist of bands of different Ba-content with or without evident resorption surface in between. They often show a week saw-tooth pattern where the Ba-content starts to decrease gradually within a band after a relatively sharp increase at the preceding resorption surface. This gentle and gradual decrease continues until the next resorption surface, where there is again a relatively sharp increase in Ba-content. To interpret the texture and cause of different kinds of zonations, a few questions need to be answered here. 


\section{What causes the growth bands in the crystals?}

The growth bands may have been caused by one or combination of the following possible processes (Ginibre et al. 2007, Shore and Fowler 1996): (1) local kinetic control (2) external factors e.g. melt composition, temperature, pressure and water-content.

Local kinetic control involves a diffusion boundary layer formed over time at the crystal-melt interface. But Ginibre et al. (2004) observed correlations between all minor and trace elements, especially $\mathrm{Ca}$, which is incompatible in sanidine, with $\mathrm{Sr}$ and $\mathrm{Ba}$, which are compatible. Development of a chemical boundary layer at the crystal interface, depleted in the sanidine components, cannot explain such correlations. This indicates that the factors controlling these zonations are external e.g. temperature and/or pressure. The fact that the major element composition within each crystal remains primarily the same over several zones (supplementary material 2) is clear evidence that changes in the bulk composition do not play a significant role in these zonations. Possible changes in water content, $\mathrm{T}$ and pressure are probably the reason. However, for the range of pressure inside the Laacher See reservoir (a gradient of $45 \mathrm{MPa}$ between LLST and ULST; Harms et al. 2004), the effect of pressure on the partition of Ba would be negligible (Guo and Green 1989). That leaves only temperature and water-content as the plausible options. For crystals growing inside a magma reservoir, changes in temperature and water-content might happen primarily in two ways: (1) by movement of the crystals to different parts of a chemically and thermally zoned reservoir, or (2) by intrusion of fresh and hotter magma followed by mixing.

The movement of the crystals to different parts of reservoir can happen through convection and in the case of Laacher See reservoir, convection inside the liquid-rich core can definitely be a possibility provided the crystallinity is low (much below the rheological lock-up i.e. 4060 vol\% crystals, Cooper and Kent 2014, Rubin et al. 2017). The vol\% of crystals within MLST samples is between 1 and 15\%. The crystallinity could have been more before the system was remobilized. However, we do not observe strong signs of late-stage melting, which implies that the crystallinity in MLST may not have been more than $40 \%$ making convection a possible process. With convection, crystals would have been transported to hotter and drier or to colder and water-rich parts. When they are transported to a hotter and drier part, the crystals undergo destabilization leading to dissolution. When the system stabilizes again, the crystals start to grow from the enriched melt. When the crystals are 
transported to a colder and water-rich (and probably less evolved) part, they continue to grow from a Ba-poor melt but without resorption. In Fig 2f, an example of such a case is visible within the crystal. However, such zonation with growth bands are also observed in ULST where the crystallinity of the samples is between 30 and $60 \%$. At $40 \%$ crystallinity (i.e. the threshold of rheological lock-up), the melt would start to behave as a rigid highly viscous crystal mush making convection not a feasible process (Kent and Cooper 2014, Rubin et al. 2017).

Similar effects can also be caused by intrusion of a fresh hot dry and mafic magma followed by mixing. The mixing would change the bulk composition of the melt affecting the composition of parts of the crystals that grow post mixing. In this case, however, we do not see changes in the major element composition of the sanidines that would provide signs of mixing. Therefore, the effects of any fresh mafic recharge would have to be limited to only thermal effects. That would be possible because of the higher rate of heat diffusion (order of $\sim 10^{-7} \mathrm{~m}^{2} / \mathrm{s}$; Romine et al. 2012; Hofmeister et al. 2016) compared to chemical diffusion (e.g. by at least 8-9 logarithmic order faster than $\mathrm{Ba}$ or $\mathrm{Sr}$ at $800^{\circ} \mathrm{C}$; Zhang et al. 2010). This would make thermal effects of the recharge reach the crystals almost immediately, and effects of changes in composition and water-content come into play much later. Ginibre et al. (2004) indeed observed effects due to chemical changes at a much larger scale (termed as large wavelength ( $>600 \mu \mathrm{m}$ wide) variations) at later stages of growth and at much less frequency.

This phenomenon seems to be the most plausible reason behind the zonation. However, this process cannot explain the growth of Ba-poor zones with sharp boundaries. There is possibility of crystals coming from a less evolved mafic magma and then growing in a more evolved hybrid magma post mixing. But lack of evidence for any chemical effects eliminates such possibility. Thus, for the growth of such Ba-poor zones, convection seems to be the only plausible explanation, and for such zonation pattern to exist in ULST and upper MLST, some local low-scale convection would have to exist, besides the mafic recharges. Such convection would probably be triggered by the fresh recharge itself followed by possible melting of the crystals. Therefore, we propose periodic mafic recharges along with local low-scale convection to be the reason behind the observed zonation pattern. 

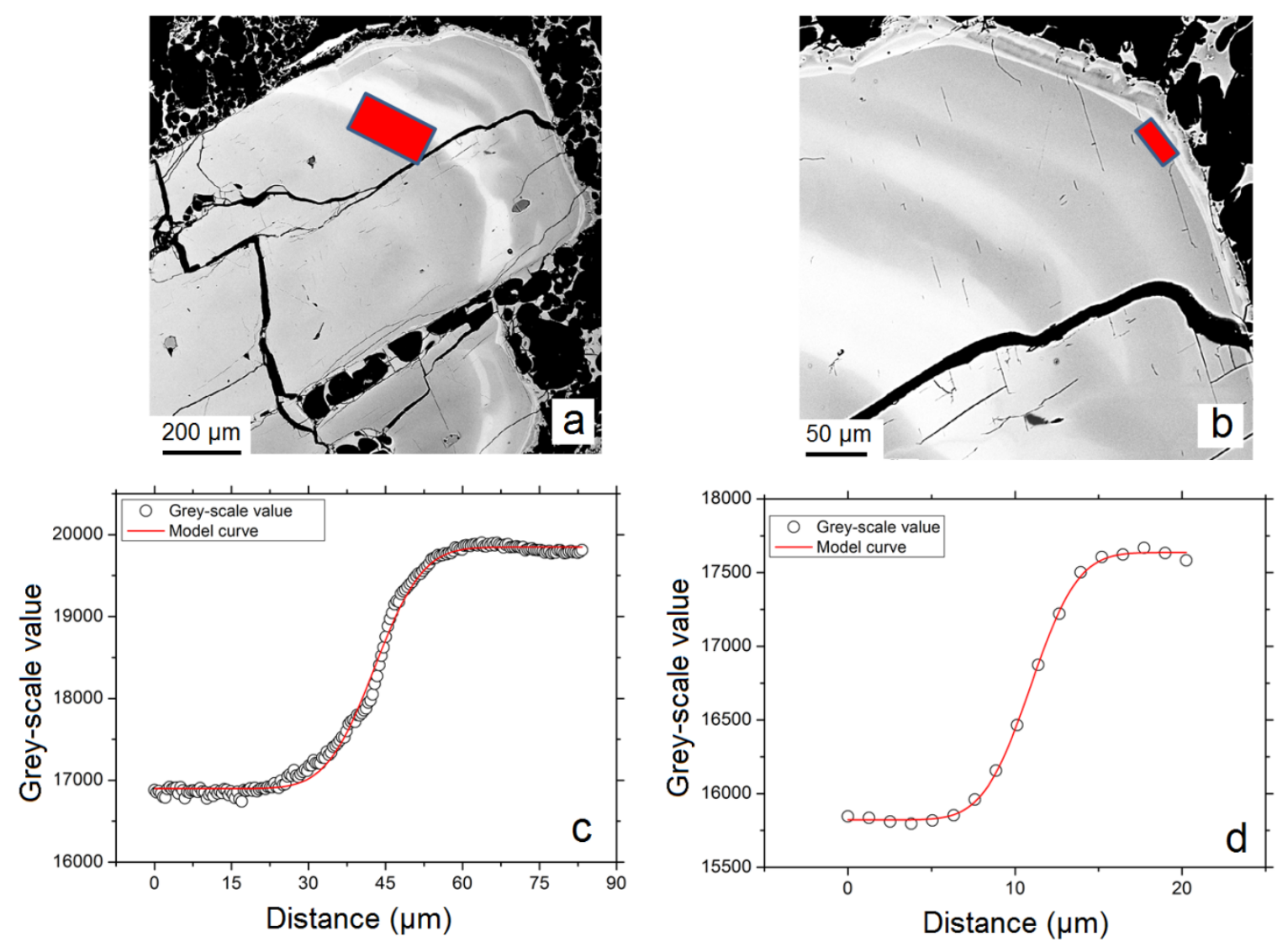

Fig 6. (a) accumulated BSE image of a selected sanidine grain. The solid red rectangle encloses the area over which the grey-scale swath profile (c) for inner boundary is taken. (b) the zoomed-in view of (a), the solid red rectangle covers the area of the swath profile (d) for gray-scale values used for diffusion modeling across the outer-most boundary. The red curves in (c) and (d) are the model curves obtained through a least square fitting.

The gradual decrease in $\mathrm{Ba}$ within each growth band can be explained by the development of a chemical boundary layer that becomes locally depleted in $\mathrm{Ba}$, a compatible element in sanidine (Ginibre et al. 2002). During the periods of growth, with increasing crystallinity, and at temperatures of $760-840{ }^{\circ} \mathrm{C}$ (constrained by Berndt et al. 2001 for MLST and ULST), chemical diffusivity of elements like Ba and Sr (already with lower diffusivities, Zhang et al. 2010) would become too slow (Eq 1) to replenish the melt composition near the crystal-melt interface leading to the observed boundary layer depletion. This process would continue until the environment around the crystal changes e.g. through dissolution or movement of the crystal. Any dissolution, as said earlier, would enrich the surrounding melt and any post-dissolution growth would be from the enriched melt causing high-Ba zones (Fig 2c, e, f and Fig 3). 


\section{What makes the occasional fine oscillatory zonation (Fig 2d)?}

This kind of zonation ( $<20 \mu \mathrm{m}$ width), is only represented either in the mantle or rim of $<5 \%$ of the crystals and is associated with very small Ba-changes $(\sim 0.2-0.5 \mathrm{wt} \%)$ at higher frequencies. These relatively fine-scale partially euhedral oscillatory zones trace the crystal shapes and probably reflect incremental diffusion-controlled growth (Haase et al. 1980, Pearce and Kolisnik 1990, Singer et al. 1995). This type of growth implies steady-state cooling, low undercooling conditions, and negligible melt convection within the diffusion boundary layer. The growth may also have been associated with slight dissolution as the zone boundaries, being typically euhedral, often also have slightly rounded corners and sporadically low amplitude undulating resorption surfaces. Ginibre et al. (2002, 2007) and Shore and Fowler (1996) have summarized the some of the existing models that are used to explain such zonation, but since their formation does not reflect, and does not allow for estimating diffusion (or crystal residence) times at large, we do not model or analyze this type of zonation further.

\section{How can the zonation patterns in the cumulates be interpreted?}

In the cumulates, as mentioned earlier, only $<1 \%$ of the sanidines are zoned. The patchy zonation of orthoclase content (i.e. Na- and K-content) in sanidines from the felsic cumulate (Fig 4 and supplementary material 1) is most probably the result of carbonate-silicate unmixing as interpreted by Rout and Wörner 2018 for similar zonation patterns in sanidines from the syenites. However, the boundaries between the Or-rich and Ab-rich phases are often not over printed by exsolution. This is probably due to fast cooling to temperatures below the solvus (712-725 ${ }^{\circ} \mathrm{C}$; Brown and Parsons 1989). The zoned crystals in the intermediate and mafic cumulates are identical to the ones in the pumice samples and hence must have formed by the similar mechanism (of only thermal effects as opposed to chemical changes as mentioned above). However, majority ( $>99 \%)$ of the crystals are unzoned. They must have either homogenized completely or grew at the reservoir boundaries and settled almost immediately before undergoing effects of any thermal changes. 


\subsubsection{How to extract crystal residence times through Ba-diffusion modeling?}

Each sanidine crystal has 2 to 4 number of significant zones (with at least $40 \%$ change in Ba). All the major zone boundaries with sharp compositional gradients (up to $20 \mu \mathrm{m}$ in length), as petrographic observations suggest, are previous resorption surfaces formed by dissolution the crystal followed by growth. This suggests that the initial compositional profile across the boundary was a sharp step profile. This satisfies one of the basic criteria of applying diffusion modeling, i.e. the initial profile (right at the beginning of diffusion) has to be a known step profile, and makes these zone-boundaries ideal candidates for diffusion modeling.

The compositional gradients across most of the zone boundaries are less than $10 \mu \mathrm{m}$ (supplementary material 2) in length and could thus be only analyzed using gray scales from BSE images to achieve the required spatial resolution. A Monte Carlo simulation suggests the spatial resolution of BSE images to be $<500 \mu \mathrm{m}$. In sanidines, the intensity of the BSEs usually depends on Orthoclase- and Ba-content (Ginibre et al. 2004). In all the samples, analyzed for diffusion chronometry, the major element is fairly constant making the Bacontent as the only controlling factor behind changes in intensities of BSEs, and therefore, the gray scale values in the BSE images. Upon comparison between the element maps of Ba and BSE images of the same crystals, an apparent linear relationship was observed between the Ba-content and the gray-scale values (Fig 5) allowing the use of grey-scale values as a proxy for Ba-content. Such correlation in case of sanidine has previously been tested by Ginibre et al. (2004) and Iovine et al. (2017). We use the grey-scale profiles (obtained as line and swath or area profiles) across zone boundaries for modeling of Ba-diffusion. The parameters and equations used for the diffusion modeling are discussed below. 


\section{Constraints on involved parameters:}

Temperature: Harms et al. (2004), through a series of experiments, estimated the temperature of crystallization of phenocrysts in the phonolite magma to be $750-760{ }^{\circ} \mathrm{C}$ at 115 to $145 \mathrm{MPa}$ pressure for the evolved phonolite melt composition i.e. top of the magma chamber or LLST. Their experiments also constrain the sanidine-in temperature for LLST at $\sim 750-775{ }^{\circ} \mathrm{C}$ for pressure between 75 and $125 \mathrm{Mpa}$. Berndt et al. (2001) have constrained the temperature of MLST and ULST at $760-780{ }^{\circ} \mathrm{C}$ and $840-860{ }^{\circ} \mathrm{C}$, respectively. Wörner and Schmincke (1984a, b) have also constrained the maximum temperature within ULST to be $880{ }^{\circ} \mathrm{C}$. With a combined consideration of all these studies, we have used $750{ }^{\circ} \mathrm{C}$ for LLST, $760{ }^{\circ} \mathrm{C}$ for MLST, $840{ }^{\circ} \mathrm{C}$ for ULST and $870{ }^{\circ} \mathrm{C}$ for the hybrid (i.e. upper ULST) samples. We have made sure to use the lower limits of the temperatures to constrain the maximum durations of diffusion.

Diffusivity: Diffusion coefficients are calculated using the Arrhenius equation between the diffusion coefficient, diffusivity parameters (activation energy and pre-exponential factor) and temperature as follows

$$
D=D_{0} e^{\frac{-E_{A}}{R T}}
$$

Where $\mathrm{D}$ is diffusion coefficient $\left(\mathrm{m}^{2} / \mathrm{sec}\right), \mathrm{E}_{\mathrm{A}}(\mathrm{kJ} / \mathrm{mol})$ is the activation energy, $\mathrm{R}[8.3145$ $\mathrm{J} /(\mathrm{mol} . \mathrm{K})]$ is the universal gas constant, $\mathrm{D}_{0}\left(\mathrm{~m}^{2} / \mathrm{sec}\right)$ is the pre-exponential factor and corresponds to the value of $\mathrm{D}\left(\mathrm{m}^{2} / \mathrm{sec}\right)$ at infinite temperature and $\mathrm{T}$ is the temperature in Kelvin. We use diffusivity data for $\mathrm{Ba}$ given by Cherniak (2002). Cherniak (2002) experimentally determined the diffusivity data for $\mathrm{Ba}$ in natural sanidine under dry $1 \mathrm{~atm}$ conditions. No compositional dependence of $\mathrm{Ba}$ diffusion was reported. No significant diffusion anisotropy was also reported as diffusion coefficients for the direction normal to (001) was comparable to those for the direction normal to (010). Thus, diffusivity data only for the direction normal to (001) was provided with activation energy of $455 \pm 20 \mathrm{~kJ} / \mathrm{mol}$ and pre-exponential factor of $2.9 \times 10^{-1} \mathrm{~m} 2 \mathrm{sec}$, which are used in this study. The given data is for the temperature range from $775{ }^{\circ} \mathrm{C}$ to $1124{ }^{\circ} \mathrm{C}$, showing an Arrhenius relationship (Eq 1) between diffusion coefficient and temperature. The temperatures used in this study lie between 750 and $870{ }^{\circ} \mathrm{C}$. We assume the Arrhenius relationship to continue down until 750 ${ }^{\circ} \mathrm{C}$ and extrapolate to obtain the diffusion coefficient values at temperatures of 750 and $760{ }^{\circ} \mathrm{C}$ using the given activation energy and pre-exponential factor. The dependence of $\mathrm{Ba}$ diffusion 
on pressure and $\mathrm{fO}_{2}$ has not been detected (Cherniak 2002, 2010) and thus, pressure and $\mathrm{fO}_{2}$ are not constrained or used in our diffusion modeling.

Table 1. Estimates of time scales obtained for diffusion across zone boundaries in the sanidines from MLST and ULST. The samples named with 'H' at the end are hybrid samples (i.e. upper ULST).

\begin{tabular}{|c|c|c|c|c|c|c|}
\hline \multirow{3}{*}{ Sample } & \multicolumn{6}{|c|}{ Diffusion time (years) } \\
\hline & \multicolumn{2}{|c|}{ Core } & \multicolumn{2}{|c|}{ Rim } & \multicolumn{2}{|c|}{ Thin outermost rim } \\
\hline & 5592 & \pm 738 & 3659 & \pm 226 & & \\
\hline MLST- & 18446 & \pm 1023 & - & - & & \\
\hline \multirow[t]{3}{*}{1034} & 15552 & \pm 1078 & 3650 & \pm 290 & & \\
\hline & 23514 & \pm 2360 & - & - & & \\
\hline & 11254 & \pm 433 & 8571 & \pm 174 & & \\
\hline \multirow{3}{*}{$\begin{array}{c}\text { MLST- } \\
1050\end{array}$} & 8598 & \pm 674 & 3608 & \pm 705 & & \\
\hline & 13278 & \pm 981 & 2488 & \pm 328 & & \\
\hline & 4283 & \pm 596 & 2894 & \pm 226 & & \\
\hline \multirow{3}{*}{$\begin{array}{l}\text { ULST- } \\
1060-51\end{array}$} & 5629 & \pm 197 & - & - & & \\
\hline & 10547 & \pm 314 & 5277 & \pm 270 & & \\
\hline & - & - & 7196 & \pm 349 & & \\
\hline \multirow{3}{*}{$\begin{array}{c}\text { ULST- } \\
1088\end{array}$} & 2073 & \pm 201 & - & - & & \\
\hline & 6140 & \pm 460 & 1711 & \pm 159 & & \\
\hline & 8716 & \pm 795 & - & - & & \\
\hline \multirow{4}{*}{$\begin{array}{l}\text { ULST- } \\
1088-\mathrm{H}\end{array}$} & 20344 & \pm 736 & 5863 & \pm 199 & 7 & \pm 0.8 \\
\hline & 1510 & \pm 165 & - & - & 7.7 & \pm 0.8 \\
\hline & - & - & 1990 & \pm 340 & & \\
\hline & 7345 & \pm 798 & 1833 & \pm 197 & & \\
\hline & 15454 & \pm 277 & 9352 & \pm 336 & & \\
\hline ULST- & 12075 & \pm 564 & - & - & 4.5 & \pm 0.5 \\
\hline \multirow[t]{4}{*}{ 1088-H1 } & 5306 & \pm 125 & 1381 & \pm 52 & & \\
\hline & - & - & - & - & 3.5 & \pm 0.2 \\
\hline & - & - & - & - & 4.7 & \pm 0.2 \\
\hline & - & - & - & - & 6.7 & \pm 1 \\
\hline ULST- & 3367 & \pm 106 & 1918 & \pm 272 & & \\
\hline \multirow[t]{2}{*}{ 1099-H } & 15133 & \pm 179 & 3158 & \pm 458 & & \\
\hline & 4021 & \pm 107 & 1537 & \pm 100 & & \\
\hline
\end{tabular}


Equation: Each zone boundary is then modeled using a least square curve fitting (using MATLAB and ORIGIN) of the diffusion profiles. We use the analytical solution for diffusion in semi-infinite system (Crank 1975) i.e.

$$
C(x, t)=\frac{\left(C_{\text {high }}+C_{\text {low }}\right)}{2}-\frac{\left(C_{\text {high }}-C_{\text {low }}\right)}{2} \times \operatorname{erf}\left(\frac{\left(x-x_{0}\right)}{\sqrt{4 D t}}\right)
$$

where $\mathrm{C}(\mathrm{x}, \mathrm{t})$ is the $\mathrm{Ba}$ concentration at position $\mathrm{x}$ after time $\mathrm{t}(\mathrm{sec}) . \mathrm{C}_{\text {low }}$ and $\mathrm{c}_{\text {high }}$ are the initial $\mathrm{Ba}$ concentrations (observed as the plateaus on both sides of the gradient), $\mathrm{D}$ is the diffusion coefficient $\left(\mathrm{m}^{2} / \mathrm{sec}\right)$ and $\mathrm{x}_{0}(\mathrm{~m})$ is the position of the diffusive interface. The curve fitting of a profile gives the corresponding diffusion time $(\mathrm{t})$. The obtained results are presented in Table 1.

\section{Durations from diffusion modeling and implications}

Pumice: The durations calculated from the diffusion modeling do not vary significantly between MLST and ULST. The total residence time-scales, calculated from the inner-most boundaries (at crystal-cores), range from $4.3 \mathrm{ky}$ to $23.5 \mathrm{ky}$ for MLST and $1.5 \mathrm{ky}$ to $20.3 \mathrm{ky}$ for ULST. As it turns out, the crystals in the MLST are slightly older compared to ULST. This is evident from their wider diffusion lengths and the calculated longer diffusion periods. The thousands of years of storage at $760-840{ }^{\circ} \mathrm{C}$ suggests a long storage at a high temperature for both MLST and ULST, and the wide range of diffusion times suggests a long and continuous period of crystallization and growth. Applying diffusion modeling to the other zones in the mantles and the rims of the crystals, gives durations of 1.4-9.3 ky. The distribution of the diffusion times plotted on a histogram (Fig 7) suggests that the formation of these boundaries occurred throughout the residence history starting from $\sim 24$ ky up until $\sim 1.5 \mathrm{ky}$ before the eruption. The distribution also suggests that the heating and dissolution events that formed these zone boundaries occurred periodically at a time-gap of $\sim 1.5-3 \mathrm{ky}$. However, not all crystals have preserved the effects of all the heating events. Table 1 suggests that the intervals between the formations of two consecutive prominent zone boundaries of a crystal can vary from 1.5 to $24 \mathrm{ky}$. While most of the younger crystals (residence time $<10$ ky) suggest an interval of $<3-6 \mathrm{ky}$ between the core and the rim, the older crystals suggest an interval of $\sim 12-24 \mathrm{ky}$. This could easily be the result of intermittent strong dissolution that dissolved the relatively younger zones preserving only the older cores. After the dissolution, rims, which are much younger compared to the cores, would form. Such strong intermittent dissolution is also supported by the observation that only 6 crystals out of 27 have residence 
times longer than 15000 years suggesting that very few of the older crystals survived all the heating events while most of them could not.

The thin outermost Ba-rich rim of the sanidines in the hybrid samples gives a very short timescale of only $4-8$ years. This implies a major heating event just a few years before the eruption. That could have been the latest recharge prior to eruption, which heated and remobilized the system, and mixed with the phonolite to form these hybrid samples (Wörner and Schmincke 1984a). In this case, that would be most probably the basanite recharge. However, the effects of that major heating event were limited to only the lower part of ULST as such Ba-rich overgrowth (and the associated duration of a few years) is not observed in the samples from MLST.

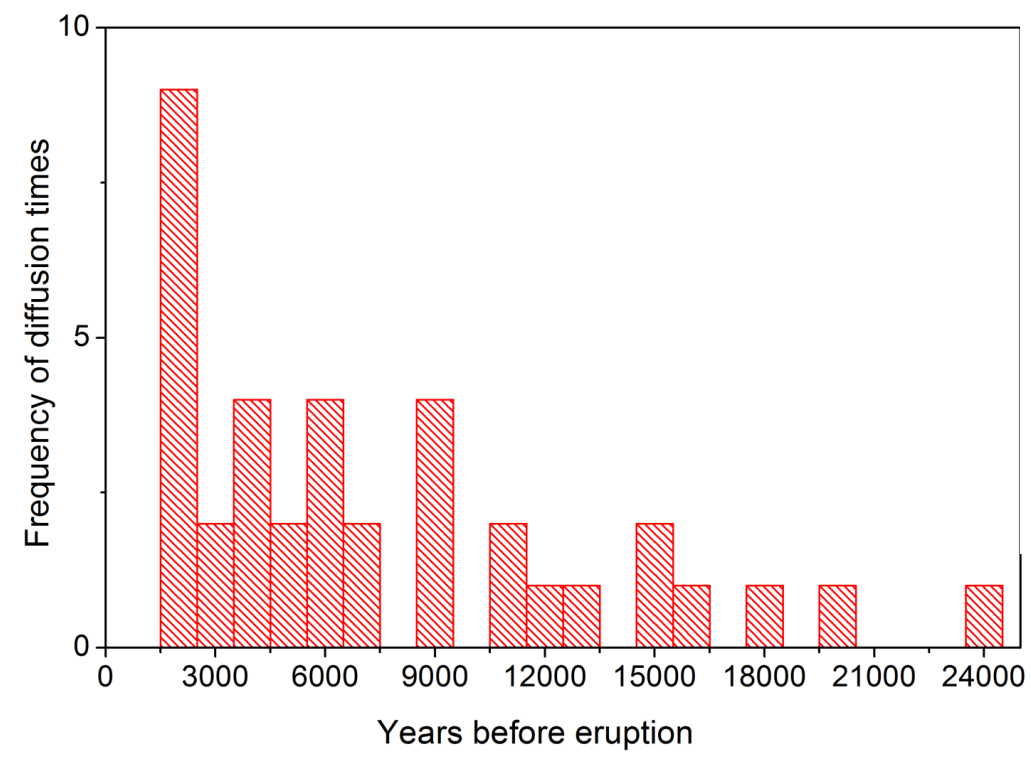

Fig 7. Histogram showing the frequency of diffusion times obtained from Ba-diffusion modeling of 39 zone boundaries in 27 crystals. The distribution of the diffusion times indicates the occurance of heating events throughout the crystal residence. The histogram excludes the durations from the outer-most boundaries.

Cumulates: No temperature constraints exist for the cumulates. We modeled the diffusion profiles assuming similar temperature as the corresponding pumice samples. For a temperature of $760-840{ }^{\circ} \mathrm{C}$, the calculated durations were at $\sim 80-210$ years. These durations, which signify the maximum time these crystals might have spent at these temperatures, are considerably shorter compared to the phenocrysts in the pumice. This suggests that either the cumulates are very young or the crystals were rapidly cooled to lower temperatures where diffusion would be extremely slow. Bourdon et al. (1994) dated a few of these cumulates and found them to be older than 19-28 ky suggesting pre-eruptive storage times (absolute age eruption age) of at least 6-15 ky. Thus, rapid cooling of these rocks to low temperatures 
followed by storage until eruption is the more plausible explanation for these very short diffusion times. We estimated the apparent diffusion threshold for $\mathrm{Ba}$ (below which diffusion is negligible) in a conductively cooling phonolitic sill to be not more than $\sim 700{ }^{\circ} \mathrm{C}$. Thus, the temperatures at which the cumulates spent most of their storage must be below $700{ }^{\circ} \mathrm{C}$.

\subsubsection{A model for storage history prior to eruption}

Fig. 8 summarizes the thermal and temporal constraints obtained on the three major kinds of eruption products from Laacher See (including the data on carbonatitic-syenites from Rout and Wörner 2018). For the phonolite, storage times up to 24 ky at temperatures of 760-840 ${ }^{\circ} \mathrm{C}$ suggests long-term storage and growth at eutectic temperature i.e. well above the solidus. The crystallinity at these near-eutectic temperatures will be $\leq 50 \%$ making this part of the reservoir (at least MLST and LLST) get stored for thousands of years as a hot liquiddominated body. This makes the storage of the phonolitic main body a clear case of warm storage. In the case of the cumulates, the general absence of zonation with very rare occurrences that give very short diffusion times suggest that the cumulates were cooled rapidly below the diffusion threshold and were stored as a rigid supremely crystalline mush. We propose a model similar to the one for the carbonatitic syenites, also crystalline nodules, which are also interpreted to have been rapidly cooled to temperatures $630-670{ }^{\circ} \mathrm{C}$ and then stored until eruption brought them to surface. As per the model, after crossing the threshold for rheological lock-up, crystals underwent conductive cooling, where the temperature rapidly dropped to sub-solidus temperatures within a period of tens to a few hundreds of years. The rocks continue to be stored at these sub-solidus temperatures as the crystalline carapaces around the liquid-rich magma body until eruption brings them to the surface. Such presence of crystalline mush surrounding a liquid-rich reservoir at the core has been proposed by several reservoir models (e.g. Annen 2009; Annen et al. 2015; Gelman et al. 2013; Caricchi et al. 2014). In the case of Laacher See, however, the size of the liquid-rich core is considerably large as LLST and MLST constitute major portion of the reservoir (as well as the eruption products, Wörner and Schmincke 1984a and b). The high above-solidus temperature of the liquid-rich core would have to be maintained by frequent recharges (Gelman et al. 2013, Huber et al. 2012), which, in this case, are evident from the multiple heating/dissolution events and the corresponding diffusion times. These frequent recharges (happening every 1500-3000 years) keep the system thermally alive. 
The storage conditions at the bottom of ULST are slightly different. With crystal content reaching at least $30-60 \%$, the mafic phonolite here was at near or beyond the threshold for rheological lock-up. However, the frequent recharges, kept this part of the system also thermally active and maintained at eutectic temperatures of $840-870{ }^{\circ} \mathrm{C}$. The final recharge that this part of the reservoir experienced happened $~ 4-8$ years before eruption, which was most probably the basanite recharge. Although this duration is estimated with a temperature of $870{ }^{\circ} \mathrm{C}$ which is based on literature data, there is possibility that the actual temperatures might even be higher, considering the higher temperature $\left(\sim 1150{ }^{\circ} \mathrm{C}\right)$ of the basanite (as estimated by our own study Sundermeyer et al. unpublished). For such high temperatures, e.g. $1010^{\circ} \mathrm{C}$ (an average of 870 and $1150{ }^{\circ} \mathrm{C}$ ), the diffusion times reduce to just $\sim 2-4$ weeks. However, in either case, the time between the recharge and the eruption was very short (maximum a few years and minimum a few weeks), and the effects of the recharge were limited to only the base of the reservoir. The other parts of the reservoir might have been heated, but the duration was very short to allow for any crystallization.

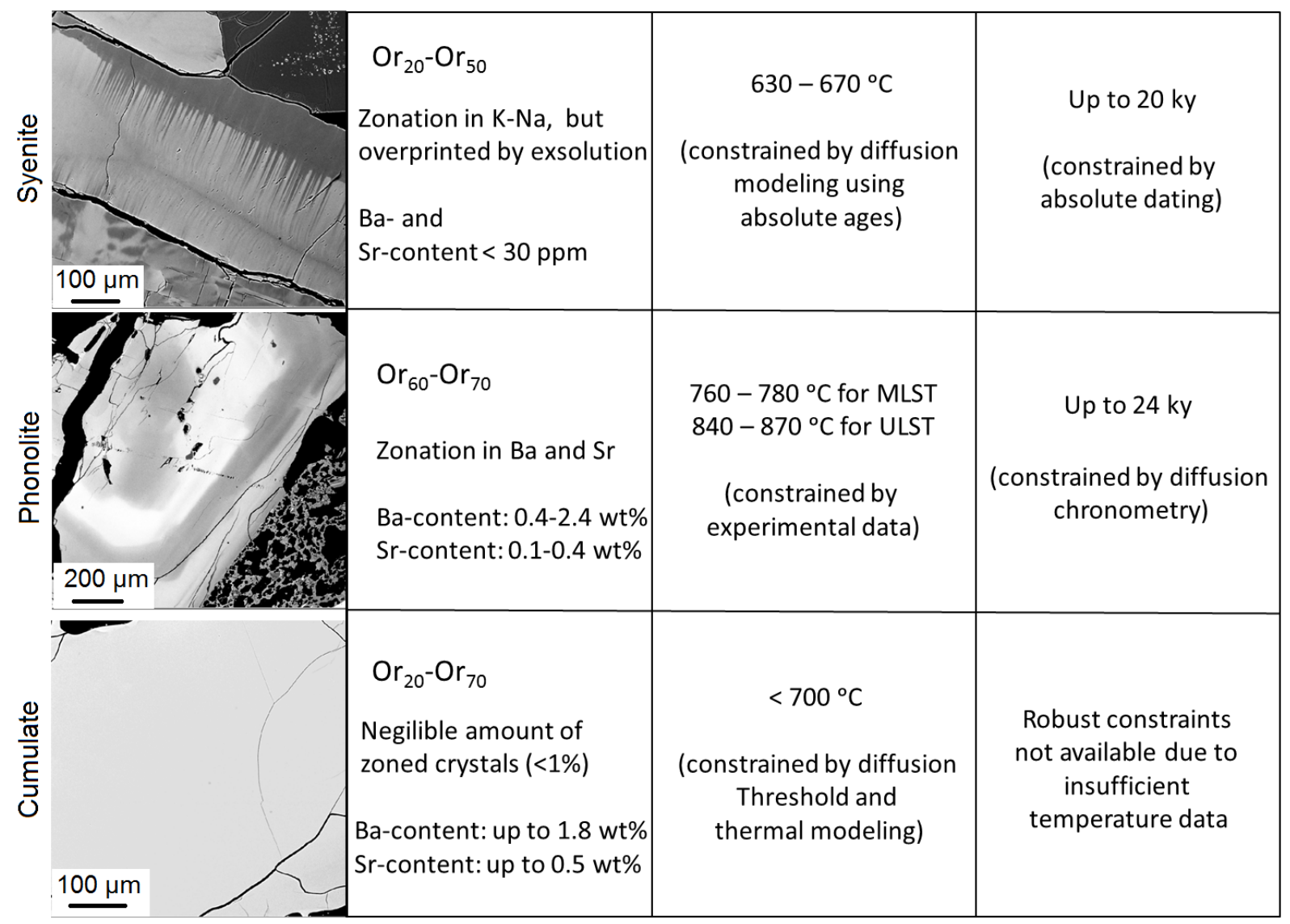

Fig 8. Comparison of results between the three major chemical and petrographical types of eruption products from Laacher See. 
We summarize the temperature vs time history for the Laacher See reservoir in Fig. 9 in terms of the crystal residence history. The three different curves in Fig. 9 denote the three major parts of the reservoir: the ULST (red), MLST and LLST (green) and the cumulates (syenitic and phonolitic; purple). The model begins at the onset of crystallization and ends at eruption. The ULST and MLST are stored largely at temperatures of $840-870{ }^{\circ} \mathrm{C}$ and $760-780{ }^{\circ} \mathrm{C}$ respectively. The storage was interrupted by heating events (interpreted to be recharge events) at a frequency of $0.33-0.67 \mathrm{ky}^{-1}$ that maintained the system at these temperatures and formed the observed dissolution-growth patterns in the crystals. The ULST specifically experienced an additional heating event just $\sim 4-8$ years before eruption, the latest of its kind. The cumulates (both carbonatitic syenites and phonolitic cumulates), were stored as a rigid crystalline mush at $<700{ }^{\circ} \mathrm{C}$. After crystallization, the temperature of these rocks dropped to these temperatures within tens of years. These cumulates may have experienced some of the heating events as well, but we do not have any petrographical evidence of this. However, Rout and Wörner (2018) concluded that the syenites experienced at least one of such heating events that led to the formation of the secondary exsolution textures in sanidines from those samples.

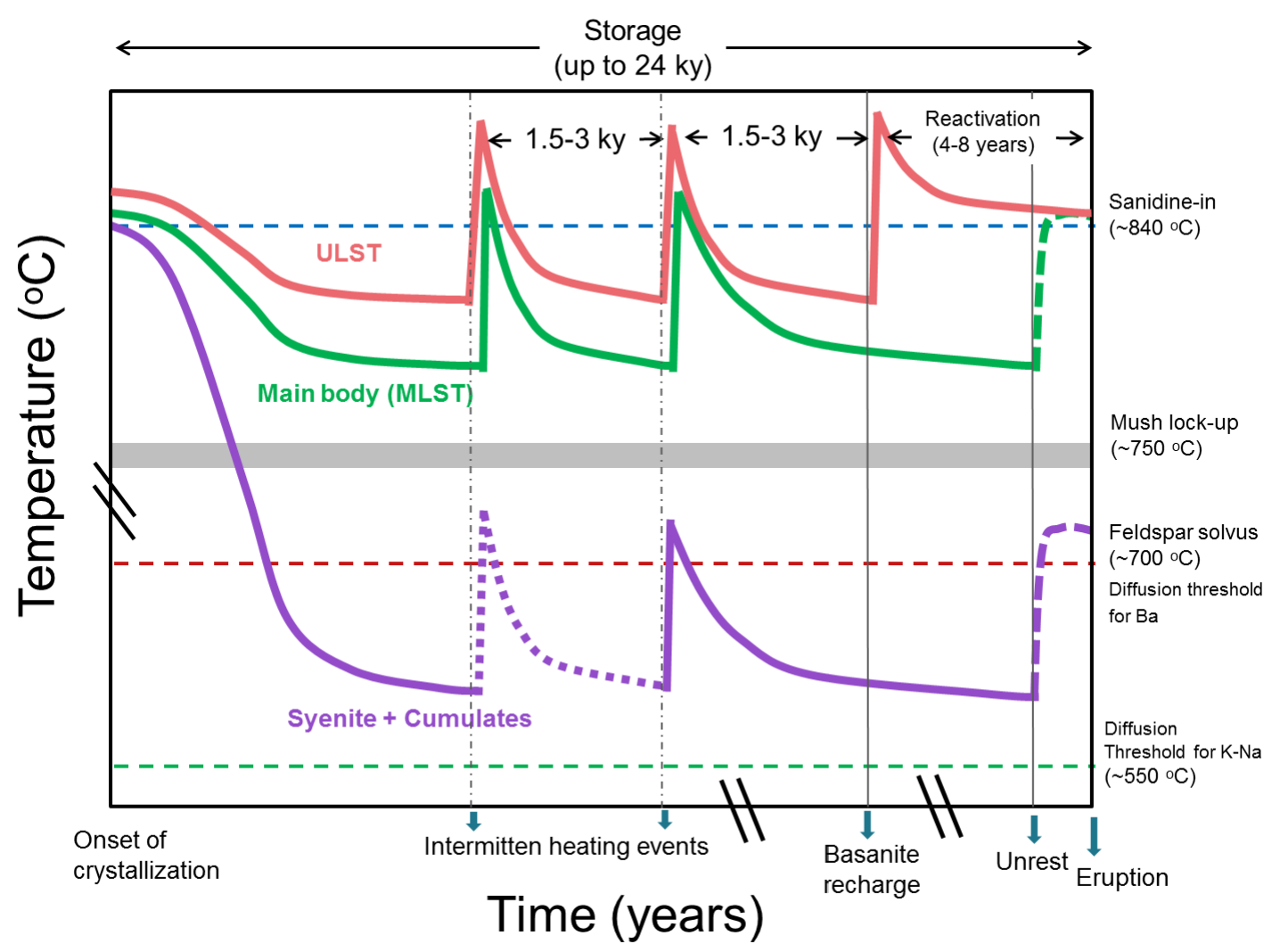

Fig 9. Schematic diagram (modified after Rout and Wörner 2018) summarizing the thermal history [temperature (T) versus time $(\mathrm{t})]$ of the Laacher See carbonatitic syenites 


\section{What triggered the eruption?}

Although there is no evidence that the basanite recharge triggered the Laacher See eruption, rapid mobilization by mafic recharges just prior to eruption is suggested as the eruptiontrigger for such long-stored systems (Girard and Stix 2009; Wolff et al. 2015; Bachmann and Bergantz 2008; Cooper and Kent 2014). Such remobilization would mean melting of mushes to form eruptible less-viscous magma (Wolff et al. 2015). However, in case of Laacher See syenites and cumulates, the petrographic observations that interstitial glass is in equilibrium with crystals, and the highly fractionated composition of the interstitial glass (Liebsch 1996, Tait et al. 1989) suggest against any late-stage strong reheating or melting that affected the entire reservoir including the surrounding mush; although there may have been a very late stage heating only a few weeks before the eruption (as suggested by Rout and Wörner 2018). However, the basanite recharge must have reheated the lower portion of the reservoir a little earlier (by a few weeks to years) causing significant melting, but with or without mixing. Although the reheating of molten core was very short or insignificant, degassing and reduction of density must have been initiated within the evolved parts of the liquid core. Recently Caricchi et al. (2018) suggested a mechanism by which a mafic recharge would cause degassing only by flushing $\mathrm{CO}_{2}$ into the reservoir and induce water exsolution, with or without limited physical and thermal interaction. This can certainly be a plausible mechanism for triggering the Laacher See eruption. Despite limited heating and limited mixing with the phonolite, it would cause gravitational destabilization of the reservoir and breaking of the crystalline carapace (to include the broken nodules), and drive the system to eruption. 


\subsection{Conclusion and summary:}

The Laacher See magma system is a combination of two different storage mechanisms, where the crystalline carapace spends much of the storage time at sub-solidus conditions while the molten core remains hot at eutectic conditions. The timing of storage for both the cases are very long. The residence time of the crystals within the molten core were up to $\sim 24 \mathrm{ky}$ as obtained from diffusion chronometry. This reinforces the idea of crystals being stored for thousands of years within silicic reservoirs (Morgan and Blake 2006; Reid 2008; Cooper and Kent 2014). The temperature of the molten core was maintained well-above the solidus by regular heating or recharge events at an interval of 1500-3000 years. This kept the system alive and made it evolve at eutectic conditions for thousands of years. These heating events caused dissolution of the long-stored crystals. Although some of them were strong enough to fully dissolve most of the old crystals, they could not initiate an eruption. However, the last of such recharge which was the basanite recharge was successful in triggering the eruption. This recharge happened maximum only a few years before the eruption. It could only generate limited heating and very last stage mixing with the phonolite. Lastly, the pre-eruptive history of Laacher See volcano suggests that (1) contrasting magma storage models can be reconcilable provided different segments of the reservoir are studied with discrete yet robust thermal and temporal constraints; (2) small yet long-stored reservoirs might not always need a strong mechanical and/or thermal trigger to erupt.

Acknowledgements: This study is a part of the doctoral research project funded by Deutscher Akademischer Austauschdienst (DAAD). We thank C. Ginibre for the BSE images of LLST and MLST samples, which were obtained as a part of her doctoral thesis. We thank B. C. Schmidt for discussions and A. Kronz for his support during microprobe analysis.

\subsection{References:}

Ackerson MR, Mysen BO, Tailby ND, Watson EB (2018) Low-temperature crystallization of granites and the implications for crustal magmatism. Nature 559:94-97.

Annen C, Pichavant M, Bachmann O, Burgisser A (2008) Conditions for the growth of a long-lived shallow crustal magma chamber below Mount Pelee volcano (Martinique, Lesser Antilles Arc). J Geophys Res 113, B07209, http://dx.doi.org/10.1029/2007JB005049

Annen C (2009) From plutons to magma chambers: thermal constraints on the accumulation of eruptible silicic magma in the upper crust. Earth Planet Sci Lett 284:409-416. 
Annen C, Blundy JD, Leuthold J, Sparks RSJ (2015) Construction and evolution of igneous bodies: towards an integrated perspective of crustal magmatism. Lithos 230:206-221.

Baales M, Jöris O, Street M et al (2002) Impact of the late glacial eruption of the Laacher See volcano, Central Rhineland, Germany. Quaternary Research 58:273-288.

Bachmann O, Bergantz GW (2008) Rhyolites and their source mushes across tectonic settings. J Petrol 49:2277-2285.

Barboni M, Boehnke P, Schmitt AK et al (2016) Warm storage for arc magmas. Proc. Natl. Acad. Sci. U.S.A. 113:13959-13964.

Berndt J, Holtz F, Koepke J (2001) Experimental constraints on storage conditions in the chemically zoned phonolitic magma chamber of the Laacher See Volcano. Contrib Mineral Petrol 140:469-486.

Blong RJ, Riede F, Chen Q (2018) A fuzzy logic methodology for assessing theresilience of past communities to tephra fall: a Laacher See eruption 13,000year BP case, Volcanica 1: 63-84.

Bogaard vdC, Bogaard vdP, Schmincke HU (1989a) Quartärgeologisch-tephrostratigraphische Neuaufnahme und Interpretation des Pleistozänprofils Kärlich. Eiszeitalter und Gegenwart 39:62-86.

Bogaard vdP, Hall CM, Schmincke HU, York D (1989b) Precise single-grain 40Ar/39Ar dating of a cold to warm climate transition in Central Europe. Nature 342:523-525.

Bogaard vdP, Schmincke HU (1990) Vulkanologische Karte der Osteifel (Maßstab 1:50000). Karlsruhe.

Bogaard vdP (1995) 40Ar/39Ar ages of sanidine phenocrysts from Laacher See tephra (12,900 yr BP); chronostratigraphic and petrological significance. Earth Planet Sci Lett 133:163-174.

Bogaard PJF, Wörner G (2003) Petrogenesis of basanitic to tholeiitic volcanic rocks from the Miocene Vogelsberg, Central Germany. J Petrol 44:569-602.

Bourdon B, Zindler A, Wörner G (1994) Evolution of the Laacher See magma chamber; evidence from SIMS and TIMS measurements of U-Th disequilibria in minerals and glasses. Earth Planet Sci Lett 126:75-90.

Brown WL, Parsons I (1989) Alkali feldspars: ordering rates, phase transformations and behaviour diagrams for igneous rocks. Mineralogical magazine 53:25-42.

Caricchi L, Sheldrake TE, Blundy J (2018) Modulation of magmatic processes by CO2 flushing. Earth and Planetary Science Letters 491:160-171.

Caricchi L, Simpson G, Schaltegger U (2014) Zircons reveal magma fluxes in the Earth's crust. Nature 511:457-461

Chamberlain KJ, Morgan DJ, Wilson CJN (2014) Timescales of mixing and mobilisation in the Bishop Tuff magma body: perspectives from diffusion chronometry. Contrib Mineral Petrol $167: 1034$

Cherniak DJ (2002) Ba diffusion in feldspar. Geochimica et Cosmochimica Acta 66:1641-1650. 
Cherniak DJ (2010) Cation diffusion in feldspars. In Y. Zhang, and D.J. Cherniak, Eds, Diffusion in Minerals and Melts, 72, p. 691-733. Reviews in Mineralogy and Geochemistry, Mineralogical Society of America and Geochemical Society.

Cisneros de León A, Schmitt AK (2019a) Intrusive reawakening of El Chichón volcano prior to its Holocene eruptive hyperactivity. Journal of Volcanology and Geothermal Research 377:53-68 Cisneros de León A, Schmitt AK, Storm S et al (2019b) Millennial to decadal magma evolution in an arc volcano from zircon and tephra of the 2016 Santiaguito eruption (Guatemala). Lithos 341342:209-222.

Condomines M, Hemond C, Allegre CJ (1988) U-Th-Ra radioactive disequilibria and magmatic processes. Earth Planet Sci Lett 90:243-262.

Cooper KM (2015) Timescales of crustal magma reservoir processes: insights from U-series crystalages. In: Caricchi L, Blundy JD (eds) Chemical, Phyiscal and Temporal Evolution of Magmatic Systems, vol Special Publications 422. Geological Society of London, London, pp $141-174$.

Cooper KM (2019) Time scales and temperatures of crystal storage in magma reservoirs: implications for magma reservoir dynamics. Philosophical Transactions of the Royal Society A: Mathematical, Physical and Engineering Sciences 377:2139.

Cooper KM, Kent AJR (2014) Rapid remobilization of magmatic crystals kept in cold storage. Nature 506:480-483.

Costa F, Dohmen R, Chakraborty S (2008) Timescales of magmatic processes from modeling the zoning patterns of crystals. In: Putirka KD, Tepley III FJ (eds) Minerals, Inclusions and Volcanic Processes. RiMG 69, Mineralogical Society of America, Chantilly, VA, USA, pp $545-594$.

Dohmen R, Faak K, Blundy JD (2017) Chronometry and speedometry of magmatic processes using chemical diffusion in olivine, plagioclase and pyroxenes. Rev. Mineral. Geochem 83:535-575.

Duda A, Schmincke HU (1978) Quaternary basanites, melilitite nephelinites and tephrites from the Laacher See Area, Germany. Neues Jahrbuch für Mineralogie-Abhandlungen 132:1-33

Ellis BS, Bachmann O, Wolff JA (2014) Cumulate fragments in silicic ignimbrites: The case of the Snake River Plain. Geology 42:431-434.

Gelman SE, Gutierrez FJ, Bachmann O (2013) On the longevity of large upper crustal silicic magma reservoirs. Geology 41:759-762.

Ginibre C (2000) Major and trace element zoning patterns in volcanic feldspars: An electron microprobe study. $\mathrm{PhD}$ thesis, Universität Göttingen.

Ginibre C, Wörner G, Kronz A (2002) Minor- and trace-element zoning in plagioclase: implications for magma chamber processes at Parinacota volcano, northern Chile. Contributions to Mineralogy and Petrology 143:300-315. 
Ginibre C, Wörner G, Kronz A (2004) Structure and dynamics of the Laacher See magma chamber (Eifel, Germany) from major and trace element zoning in sanidine: a cathodoluminescence and electron microprobe study. J Petrol 45:2197-2223.

Ginibre C, Wörner G, Kronz A (2007) Crystal zoning as an archive for magmatic evolution. Elements 3:261-266.

Girard G, Stix J (2009) Magma recharge and crystal mush rejuvenation associated with early postcollapse upper basin member rhyolites, Yellowstone Caldera, Wyoming. J Petrol 50:20952125 .

Goepel A, Lonschinski M, Viereck L, Büchel G et al. (2015) Volcano-tectonic structures and CO2 degassing patterns in the Laacher See basin, Germany, Int. J. Earth Sci. 104:1483-1495.

Guo J, Green TH (1989) Barium partitioning between alkali feldspar and silicate liquid at high temperature and pressure. Contrib Mineral Petrol 102: 328.

Haase CS, Chadam J, Feinn D, Ortoleva P (1980) Oscillatory Zoning in Plagioclase Feldspar. Science 209 (4453), 272-274.

Harms E, Schmincke HU (2000) Volatile composition of the phonolitic Laacher See magma $(12,9000$ yr BP); implications for syn-eruptive degassing of S, F, Cl and H2. Contrib Mineral Petrol 138:84-98.

Harms E, Gardner JE, Schmincke HU (2004) Phase equilibria of the Lower Laacher See Tephra (East Eifel, Germany): constraints on pre-eruptive storage conditions of a phonolitic magma reservoir. J Volcanol Geotherm Res 134:135-148.

Hawkesworth C, George R, Turner S, zellmer G (2004) Time scales of magmatic processes. Earth Planet Sci Lett 218:1-16.

Hensch M, Dahm T, Ritter J, Heimann S, Schmidt B, Stange S, Lehmann K (2019) Deep lowfrequency earthquakes reveal ongoing magmatic recharge beneath Laacher See Volcano (Eifel, Germany), Geophysical Journal International 216:2025-2036.

Hofmeister AM, Sehlke A, Avard G et al. (2016) Transport Properties of Glassy and Molten Lavas as a Function of Temperature and Composition. Journal of Volcanology and Geothermal Research 327: 330-348.

Huber C, Bachmann O, Dufek J (2012) Crystal-poor versus crystal-rich ignimbrites: a competition between stirring and reactivation. Geology 40:115-118.

Iovine RS, Fedele L, Mazzeo FC et al (2017) Timescales of magmatic processes prior to the $\sim 4.7 \mathrm{ka}$ Agnano-Monte Spina eruption (Campi Flegrei caldera, Southern Italy) based on diffusion chronometry from sanidine phenocrysts. Bull Volcanol 79:18.

Kahl M, Chakraborty S, Pompilio M, Costa F (2015). Constraints on the nature and evolution of the magma plumbing system of Mt. Etna Volcano (1991-2008) from a combined thermodynamic and kinetic modelling of the compositional record of minerals. Journal of Petrology 56:20252068 . 
Kaiser JF, de Silva S, Schmitt AK et al (2017) Million-year melt-presence in monotonous intermediate magma for a volcanic-plutonic assemblage in the Central Andes: contrasting histories of crystal-rich and crystal poor super-sized silicic magmas. Earth Planet. Sci. Lett. 457:73-86.

Leder J, Wenzel F, Daniell JE, Gottsch“ammer E (2017) Loss of residential buildings in the event of a re-awakening of the Laacher See Volcano (Germany), J. Volc. Geotherm. Res. 337: 111-123.

Liebsch H (1996) Die Genese der Laacher See-Karbonatite. Dissertation, Georg-August Universität, Göttingen.

Morgan DJ, Blake S, Rogers NW et al (2004) Time scales of crystal residence and magma chamber volumes from modelling of diffusion profiles in phenocrysts: Vesuvius 1944. Earth Planet Sci Lett 222:933-946.

Morgan DJ, Blake S (2006) Magmatic residence times of zoned phenocrysts: introduction and application of the binary element diffusion modelling (BEDM) technique. Contrib Mineral Petrol 151:58-70.

National Academies of Sciences, Engineering, and Medicine (2017) Volcanic Eruptions and Their Repose, Unrest, Precursors, and Timing. Washington, DC: The National Academies Press. https://doi.org/10.17226/24650

Pearce TH, Kolisnik AM (1990) Observations of plagioclase zoning using interference imaging. Earth-Science Reviews 29:9-26.

Reid MR (2008) How long does it take to supersize an eruption? Elements 4:23-28.

Robock A, Ammann CM, Oman L, Shindell D, Levis S, Stenchikov G (2009) Did the Toba volcanic eruption of $\sim 74 \mathrm{ka}$ BP produce widespread glaciation? Journal of Geophysical Research: Atmospheres (1984- 2012) 114(D10)

Romine WL, Whittington AG, Nabelek PI et al. (2012) Thermal diffusivity of rhyolitic glasses and melts: effects of temperature, crystals and dissolved water. Bull Volcanol 74: 2273.

Rout SS, Schmidt BC, Wörner G (2019) Constraints on non-isothermal diffusion modeling: an experimental analysis and error assessment using halogen diffusion in melts. American Mineralogist, in press.

Rout SS, Wörner G (2018) Zoning and exsolution in alkali feldspars from Laacher See volcano (Western Germany): constraints on temperature history prior to eruption. Contributions to Mineralogy and Petrology 173:95.

Rubin A, Cooper KM, Leever M et al (2016) Changes in magma storage conditions following caldera collapse at Okataina Volcanic Center, New Zealand. Contributions to Mineralogy and Petrology 171(4):1-18 doi:10.1007/s00410-015-1216-6.

Rubin AE, Cooper KM, Till CB et al (2017) Rapid cooling and cold storage in a silicic magma reservoir recorded in individual crystals. Science 356:1154-1156. 
Schmincke HU, Fisher RV, Waters AC (1973) Antidune and chute and pool structures in the base surge deposits of the Laacher See area, Germany. Sedimentology 20:553-74.

Schmincke HU (2007) The Quaternary volcanic fields of the east and west Eifel (Germany). In: Ritter JRR \& Christensen UR (ed) Mantle Plumes, a Multidisciplinary Approach. Springer, Berlin, pp 241-322.

Schmincke HU (2008) Quaternary volcanism of the east and west Eifel (Central Europe). In: McCann $\mathrm{T}$ (ed) Geology of Central Europe. Geological Society, London, pp 1318-1333.

Schmitt AK, Wetzel F, Cooper KM, Zou H, Wörner G (2010) Magmatic longevity of Laacher See volcano (Eifel, Germany) indicated by U-Th dating of intrusive carbonatites. J Petrol 51:10531085.

Schmitt AK (2011) Uranium series accessory crystal dating of magmatic processes. Annu Rev Earth Planet Sci 39:321-349.

Self S, Blake S (2008) Consequences of explosive super-eruptions. Elements 4:41-46.

Shore M, Fowler AD (1996) Oscillatory zoning in minerals: a common phenomenon. The Canadian Mineralogist 34:1111-1126.

Sigl M, Winstrup M, McConnell JR et al (2015) Timing and climate forcing of volcanic eruptions for the past 2,500 years. Nature 523:543-549.

Singer BS, Dungan MA, Layne GD (1995) Textures and Sr, Ba, Mg, Fe, K, and Ti compositional profiles in volcanic plagioclase: Clues to the dynamics of calcalkaline magma chambers. American Mineralogist 80:776 - 798.

Spear FS (2014) The duration of near-peak metamorphism from diffusion modelling of garnet zoning. J. Metamorph. Geol. 32:903-914.

Tait SR (1988) Samples from the crystallising boundary layer of a zoned magma chamber. Contrib Mineral Petrol 100:470-483.

Tait SR, Wörner G, Bogaard vdP, Schmincke HU (1989) Cumulate nodules as evidence for convective fractionation in a phonolite magma chamber. J Volcanol Geotherm Res 37:21-37.

Viereck L (1984) Geologische und petrologische Entwicklung des pleistozänen Vulkankomplexes Rieden, Ost-Eifel, Bochumer geol. geotechn. Arbeiten 17.

Wedepohl KH, Baumann A (1999) Central European Cenozoic plume volcanism with OIB characteristics and indications of a lower mantle source. Contrib Mineral Petrol 136:225-239.

Wilson M, Downes H (1991) Tertiary quaternary extension-related alkaline magmatism in Western and Central Europe. J Petrol 32:811-849

Wolff JA, Ellis BS, Ramos FC et al (2015) Remelting of cumulates as a process for producing chemical zoning in silicic tuffs: A comparison of cool, wet and hot, dry rhyolitic magma systems. Lithos 236-237:275-286.

Wörner G (1982) Geochemisch-mineralogische Entwicklung der Laacher See-Magmakammer. PhD thesis, Ruhr-Universität Bochum. 
Wörner G, Beusen JM, Duchateau N, Gijbels R, Schmincke HU (1983) Trace element abundances and mineral/melt distribution coefficients in phonolites from the Laacher See Volcano (Germany). Contrib Mineral Petrol 84:152-173.

Wörner G, Wright TL (1984) Evidence for magma mixing within the Laacher See magma chamber (East Eifel, Germany). J Volcanol Geotherm Res 22:301-327.

Wörner G, Schmincke HU (1984a) Mineralogical and chemical zonation of the Laacher See tephra sequence (East Eifel, W. Germany). J Petrol 25:805-835.

Wörner G, Schmincke HU (1984b) Petrogenesis of the zoned Laacher SeeTephra. (East Eifel, W. Germany). J Petrol 25:836-851

Wörner G, Viereck L, Plaumann S et al (1988). The quaternary Wehr volcano: a multiphase evolved eruption center in the East Eifel Volcanic Field (FRG). Neues Jahrbuch für Mineralogie, Abhandlungen 159:73-99.

Zellmer G, Turner S, Hawkesworth C (2000) Timescales of destructive plate margin magmatism: new insights from Santorini, Aegean volcanic arc. Earth Planet Sci Lett 174:265-281.

Zhang Y, Ni H, Chen Y (2010) Diffusion data in silicate melts. In Y. Zhang, and D.J. Cherniak, Eds, Diffusion in Minerals and Melts, 72, p. 311-408. Reviews in Mineralogy and Geochemistry, Mineralogical Society of America and Geochemical Society. 


\title{
Chapter 4: Constraints on non-isothermal diffusion modeling: an experimental analysis and error assessment using halogen diffusion in melts
}

\author{
Smruti Sourav Rout, Burkhard C. Schmidt, Gerhard Wörner
}

Geowissenschaftliches Zentrum, Georg-August-Universität (GZG),

Goldschmidtstrasse 1, 37077 Göttingen, Germany

\begin{abstract}
Diffusion chronometry on zoned crystals allows constraining duration of magmatic evolution and storage of crystals once temperatures are precisely known. However, non-isothermal diffusion is common in natural samples and thus, time-scales may not be determined with confidence while assuming isothermal conditions. The "Non-isothermal Diffusion Incremental Step (NIDIS) model" (Petrone et al. 2016) is proposed for such cases for a nonisothermal diffusive analysis. We conducted diffusion experiments with stepwise temperature changes to analyze and test the model, evaluated the associated errors and improved the accuracy by suggesting an alternative algorithm to model diffusion times. We used $\mathrm{Cl}$ and $\mathrm{F}$ ( $\leq 0.4$ wt.\%) as the diffusing elements in nominally anhydrous $\left(\mathrm{H}_{2} \mathrm{O} \leq 0.3\right.$ wt.\%) phonolitic melt with composition of Montana Blanca (Tenerife, Spain) in an experimental set-up that successively generates multiple diffusive interfaces for different temperatures by adding glass blocks of different $\mathrm{Cl}$ and $\mathrm{F}$ concentrations. This compound set of two diffusion interfaces represents distinct compositional zones that diffusively interact at different temperatures, which can be taken as an equivalent to non-isothermal diffusion in zoned magmatic crystals. The starting temperature ranged from 975 to $1150{ }^{\circ} \mathrm{C}$ and each set of experiments included a temperature change of $85-150{ }^{\circ} \mathrm{C}$ and a total duration of 8-12 hours. The experiments were carried out in an internally heated pressure vessel equipped with a rapid quench device at 1 kbar pressure. $\mathrm{Cl}$ and $\mathrm{F}$ concentration profiles were obtained from the quenched samples by electron microprobe analysis. Although the estimated diffusion times from the NIDIS-model matched well with true experimental values, the errors on estimated time-scales, accounting for errors in curve-fitting and uncertainty in temperature, were $\pm 10-62 \%(1 \sigma)$. The errors are much larger at $61-288 \%(1 \sigma)$ when the uncertainty in diffusivity parameters is included. We
\end{abstract}


discuss the efficiency and limitations of the model, assess the contribution from different sources of error, and their extent of propagation. A simpler alternative algorithm is proposed that reduces errors on the estimates of diffusion and residence time to $10-32 \%(1 \sigma)$ and 60 $75 \%(1 \sigma)$, with and without including uncertainty in diffusivity parameters, respectively. Using this new algorithm, we recalculated the individual diffusion times for the clinopyroxene crystals analyzed by Petrone et al. (2016) and obtained a significantly reduced error of $26-40 \%$ compared to the original error of $61-100 \%$. We also analyzed a sanidine megacryst from Taapaca volcano (N. Chile) as a test case for non-isothermal modeling and obtained diffusion times of $1.5-9.4 \mathrm{ky}$, which is significantly different from isothermal analyses including a previous study on similar sample. In this analysis, the error estimated by our new method is reduced by $63-70 \%$.

\section{Keywords}

Non-isothermal diffusion, Diffusion experiment, Error assessment, Electron microprobe, Halogen diffusion

\subsection{Introduction}

The pre-eruptive history of magmas at active and potentially dangerous volcanoes is archived in the compositional zonation in magmatic crystals. These zonations record the nature and rates of magmatic processes and the time-scales of magma storage prior to eruption. In the past decades, petrographic and compositional analysis of minerals have allowed volcanologists a better comprehension of storage conditions and storage periods of magma as well as the nature and timing of eruption triggering events (e.g. Reid 2003; Hawkesworth et al. 2004; Morgan and Blake 2006; Cooper and Kent 2014; Rubin et al. 2017). Minerals that crystallize from a melt over the course of time record any changes in the crystallizing conditions (temperature, pressure, oxygen fugacity; e.g. Holland and Blundy 1994; Johnson and Rutherford 1989; Ridolfi et al. 2010) and melt composition (e.g. Ginibre et al. 2007; Ruprecht and Wörner 2007; Chakraborty 2008; Costa and Chakraborty 2004; Morgan and Blake 2006; Costa and Morgan 2010). Two methods are employed to extract information on time-scales of crystallization and magmatic processes. One is the direct dating of crystals using short-lived U-series isotopes (e.g. Condomines et al. 1988; Hawkesworth et al. 2000; Hawkesworth et al. 2004; Schmitt 2011) that provides insights into their time of formation and thus, gives minimum values for the age and storage time of magmas. For example, ${ }^{230} \mathrm{Th}$ - 
${ }^{226} \mathrm{Ra}$ dating applied to Santorini (Zellmer et al. 2000) and Kilauea Volcano, Hawaii (Cooper et al. 2001), and U-Th-Ra disequilibria applied to MORB and OIB (Condomines et al. 1988) constrain durations of fractional crystallization, magma transport and residence up to $10^{5}$ years. A second approach to estimate residence time and ages of crystals is based on diffusion speedometry of zoned phenocrysts which has been applied, for example, to plagioclase (Zellmer et al. 1999; Costa et al. 2003), pyroxene (Morgan et al. 2004; Chamberlain et al. 2014), olivine (Costa and Dungan 2005; Costa and Chakraborty 2004), quartz (Chamberlain et al. 2014; Ackerson et al. 2018) and sanidine (Zellmer and Clavero 2006; Chamberlain et al. 2014; Iovine et al. 2017).

These studies assumed isothermal conditions during diffusion and thus a constant diffusion coefficient. However, under natural conditions, temperatures may vary throughout the growth of a crystal (Costa et al. 2008). Such variation is often associated with magma mixing, or magma transport that lead to compositional zonation in the crystal (Morgan et al. 2004; Watson and Müller 2009; Chakraborty 2008; Costa and Chakraborty 2004) and is shown by distinct dissolution interfaces and regrowth events that clearly indicate temperature variations of $100{ }^{\circ} \mathrm{C}$ or more (e.g. Ginibre et al. 2004, Cooper and Kent 2014). In earlier diffusion studies, lack of constraints on intra-crystal temperature variations allowed only isothermal modeling of diffusion boundaries. Many cases consider only the final resorption-growth event and this should give meaningful results for calculated diffusion times using a single temperature value (e.g. Chamberlain et al. 2014 and our own study of the Campi Flegrei, Italy, Iovine et al. 2017). In these and many other cases only a single zone boundary was analyzed for a fixed temperature. In other cases, when there was no constraint to account for possible temperature variation during growth, the potential information that can be gained from multiple diffusion zones that developed during the larger part of a crystal's history is limited. In such cases, isothermal diffusion modeling of multiple growth and diffusion gradients will not yield robust time-scales and a non-isothermal diffusion modeling is necessary. And In order to apply non-isothermal diffusion modeling it is vital to know the temperature-time history of the crystal.

Lasaga (1983) already addressed the issue of the non-isothermal nature of diffusion in minerals and suggested methods to model diffusion during consistent cooling intervals. Similar cooling models have been used by other studies to constrain diffusion in minerals of high-grade metamorphic rocks (Ganguly et al. 2000), martian meteorite (Bloch and Ganguly 
2014), cooling lavas (Gardner et al. 2012; Befus et al. 2015), lunar glasses (Saal et al. 2008), and granites (Ackerson et al. 2018). However, for magmatic environments, where crystals undergo frequent heating, cooling and growth events at various amplitude and frequencies (Ginibre et al. 2007; Cooper and Kent 2014; Rubin et al. 2017), applying non-isothermal analysis is a challenge. Ideally, the temperature associated with each growth zone is needed for precisely constraining the time-scales and frequency of magmatic processes that form the zonation, as well as for estimating the total residence time.

To address diffusion in more complex magmatic crystals, Petrone et al. (2016) suggested a "Non-isothermal diffusion incremental step (NIDIS) model" to obtain diffusion time-scales from different zone boundaries that formed at different temperatures within a single crystal. The model uses different diffusion coefficients for different diffusive boundaries according to different temperatures for the corresponding zones. Thus, it is possible to extract information from all diffusive boundaries unlike the usual isothermal analysis where only the outer-most boundary gives robust information. Petrone et al. (2016) used the model to constrain the residence history of compositionally zoned clinopyroxene crystals from Stromboli volcano (Italy) from the present-day activity ( $<2000$ years). In this study, we test the accuracy of this model through a series of controlled experiments, ground-truth the model by analyzing the associated errors and give a simpler yet relatively more accurate alternative mechanism to use the non-isothermal diffusion model using the underlying basic concept.

\subsubsection{Non-isothermal diffusive analysis and the NIDIS model:}

The diffusion coefficient (D) is strongly dependent on temperature (T) and varies exponentially through the Arrhenius equation (Eq 1):

$$
D=D_{0} e^{\frac{-E_{A}}{R T}}
$$

where $\mathrm{E}_{\mathrm{A}}(\mathrm{J} / \mathrm{mol})$ is the activation energy, $\mathrm{R}[8.3145 \mathrm{~J} /(\mathrm{mol} \cdot \mathrm{K})]$ is the universal gas constant, $\mathrm{D}_{0}\left(\mathrm{~m}^{2} / \mathrm{s}\right)$ is the pre-exponential factor and corresponds to the value of $\mathrm{D}\left(\mathrm{m}^{2} / \mathrm{s}\right)$ at infinite temperature and $\mathrm{T}$ is the temperature in Kelvin. Petrone et al. (2016) suggested a backward model in which the diffusion time associated with individual diffusive boundaries can be constrained. For this model to work, the parameters in $\mathrm{Eq} 1\left(\mathrm{E}_{\mathrm{A}}\right.$ and $\left.\mathrm{D}_{\mathrm{o}}\right)$, that are used to calculate diffusion coefficient (D) for different temperatures, have to be known. In total, four conditions need to be fulfilled: (1) concentration and temperature independent $\mathrm{D}_{0}$ and $\mathrm{E}_{\mathrm{A}},(2)$ one-dimensional diffusion in a semi-infinite medium (as reported by Crank 1975), (3) periods 
between temperature changes are isothermal, (4) duration of temperature change between the isothermal periods is negligible. However, in the later sections, we present a method of using the model when condition 3 and 4 from above are not satisfied.
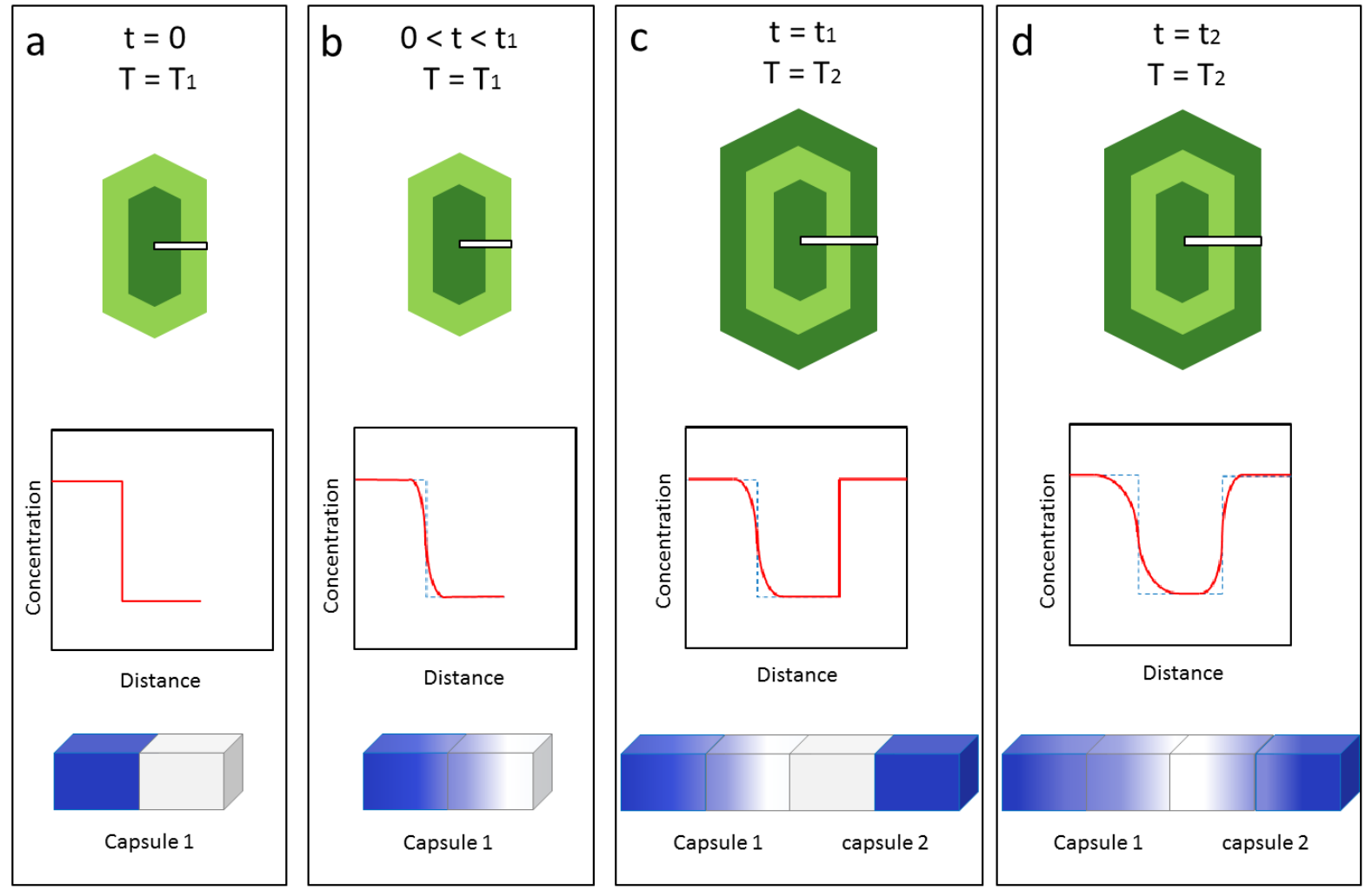

Fig 1: Schematic diagram that explains the model and the steps of the experiment. (a) At $t=0$ and $T=T_{1}$, the mantle is formed. The compositional profile across the core-mantle boundary at this point is an initial step function. The equivalent step in the experiment is the start of the experiment where capsule 1 is heated to $T_{1}$ and diffusion begins. (b) diffusion continues at $\mathrm{T}=\mathrm{T}_{1}$ across the core-mantle boundary and the compositional profile is gradually smoothened out. (c) At $\mathrm{t}=\mathrm{t}_{1}$, temperature is changed to $\mathrm{T}_{2}$ and the rim of the crystal is formed. The mantle-rim compositional profile at this stage is a sharp step function. In the experiment, capsule 2 is added to the system that mirrors mantle-rim boundary. (d) At $t=t_{2}\left(t_{2}>t_{1}\right)$, closure of diffusion occurs. By this stage, the core-mantle boundary has undergone diffusion for $t_{1}$ time at $T_{1}$ temperature, then again for $t_{2}$ time at $T_{2}$ temperature where the mantle-rim boundary has undergone diffusion only for $t_{2}$ time at $T_{2}$ temperature. In the experiment, this is the stage where the samples are rapidly quenched and closure of diffusion occurs.

To explain the model, we use the simple case of a crystal with three growth zones of different composition that were formed at different temperatures (Fig 1) which are known. Following the core of the crystal, the mantle is formed at a temperature $T_{1} . T_{1}$ is maintained until the rim of the crystal is formed after some time at temperature $T_{2} . T_{2}$ is maintained until eruption. The time interval between the formation of the mantle and the rim is $t_{1}$ whereas the interval between formation of rim and closure of diffusion is $t_{2}$. The term "closure" is used for the condition when temperature drops to a particular value below which diffusion is negligible 
(known as closure temperature). In this case the closure of diffusion will be at the moment of eruption when the temperature drops below closure temperature. In the above case, the coremantle boundary in a crystal undergoes diffusion for a duration of $t_{1}$ at temperature $T_{1}$ and then again for $t_{2}$ amount of time at temperature $T_{2}$, whereas the mantle-rim boundary undergoes diffusion only for the duration of $t_{2}$ at temperature $T_{2}$. The Petrone et al. (2016) model operates backwards starting from the rim and ending at the core. For the mantle-rim boundary, the diffusion time $t_{2}$ is obtained by applying a curve-fitting to the concentration profile using the diffusion coefficient $\mathrm{D}_{2}$ for temperature $\mathrm{T}_{2}$ (see "Results and discussion" below for curve fitting details). Then an imaginary timescale $t_{3}$ is obtained for the same profile using the diffusion coefficient $D_{1}$ for the temperature $T_{1}$. This imaginary time-scale $t_{3}$ is the duration one would get if the mantle-rim boundary diffused entirely at temperature $\mathrm{T}_{1}$ instead of $T_{2}$. Then, the core-mantle boundary is assumed to have diffused only at $T_{1}$ and thus is modeled for $T_{1}$ to give a second imaginary time-scale $t_{4}\left(\right.$ using $\left.D_{1}\right)$. The difference between $t_{4}$ and $t_{3}$ is $t_{1}$ which is the actual diffusion time at the core-mantle boundary at $T_{1}$. The sum of $t_{1}$ and $t_{2}$ gives the total residence time of the crystal.

\subsubsection{Alternative curve parameter method:}

Mathematically (see below), the above steps are equivalent to arithmetically operating the corresponding products of diffusion coefficient (D) and time (t), Dt. Here onwards, we refer to $\mathrm{Dt}$, which is specific to each diffusion profile, as 'curve parameter'.

Let the curve parameter for core-mantle boundary (profile 1) and mantle-rim (profile 2) be $\mathrm{CP}_{1}$ and $\mathrm{CP}_{2}$ respectively. Temperature values are $\mathrm{T}_{1}$ and $\mathrm{T}_{2}$ and corresponding diffusion coefficients are $D_{1}$ and $D_{2}$ respectively. The durations to be obtained are $t_{1}$ and $t_{2}$, where $t_{2}$ is the diffusion time after the mantle-rim boundary (profile 2) was formed and $t_{1}$ is the diffusion time of core-mantle boundary (profile 1) before mantle-rim boundary (profile 2) started to form.

As per NIDIS model by Petrone et al. (2016), $t_{2}=\frac{C P_{2}}{D_{2}}$.

Then, the fictional time scale $t_{3}$ and $t_{4}$ are obtained as $t_{3}=\frac{C P_{2}}{D_{1}}$ and $t_{4}=\frac{C P_{1}}{D_{1}}$;

Finally, $\mathrm{t}_{1}$ is obtained by subtracting $\mathrm{t}_{3}$ from $\mathrm{t}_{4}$.

Thus, $t_{1}=t_{4}-t_{3}=\frac{C P_{1}}{D_{1}}-\frac{C P_{2}}{D_{1}}=\frac{\left(C P_{1}-C P_{2}\right)}{D_{1}}$

From the above equation, $D_{1} t_{1}=C P_{1}-C P_{2}$ 
Thus, instead of following the steps of NIDIS model as given in Petrone et al. (2016), $t_{1}$ can directly be obtained by taking the ratio of (1) the difference in curve parameters of the profiles of core-mantle and mantle-rim boundary i.e. $\left(\mathrm{CP}_{1}-\mathrm{CP}_{2}\right)$ and $(2)$ the corresponding diffusion coefficient $\left(\mathrm{D}_{1}\right.$, obtained using $\left.\mathrm{T}_{1}\right)$. The curve parameter for each profile can be easily obtained from the curve fitting.

This illustrates the underlying concept behind the model where the curve parameters are arithmetically added for a particular diffusive boundary as the temperature changes through the course of diffusion. Thus, if a diffusive boundary has undergone temperatures $T_{1}, T_{2}, T_{3}$ $\ldots T_{n}$. for durations $t_{1}, t_{2}, t_{3} \ldots t_{n}$ respectively, then the final curve parameter $(D t)$ for that diffusive boundary would be a summation of all individual curve parameters $\left(D_{1} t_{1}, D_{2} t_{2}, D_{3} t_{3}\right.$ $\ldots D_{n} t_{n}$ ) from all growth intervals of the crystal. Mathematically, the final $D t=\Sigma D_{n} t_{n}$. The advantage of this set of calculation steps is that the uncertainty in temperature contributes only once to the initial time-scale $t_{1}$ as well as to every successive time-scale. This is in contrast to the algorithm given by Petrone et al. (2016), where the uncertainty in temperature contributes more than once as the time-scale for every boundary other than the outer-most boundary are obtained using imaginary time-scales which are individually calculated using temperature data. Both calculation models assume that all interfaces between the growth zones were initially perfect compositional step functions. When applying this to natural crystals where growth zones are separated by resorption interfaces, this is a valid assumption. In this study, we tested the reliability and accuracy of the NIDIS model by experimentally generating a series of compositional interfaces at different temperatures between melts of constant major element composition but with different $\mathrm{Cl}$ and $\mathrm{F}$ concentrations. Diffusion gradients that had formed during the experiment at variable consecutive temperatures were measured by electron microprobe across the diffusive interfaces and were analyzed and modeled with the NIDIS algorithm given by Petrone et al. (2016) and the alternative algorithm given in this study. The errors originating from both of the algorithms were compared. 


\subsection{Experimental and analytical techniques}

\subsubsection{Starting material:}

For our experiments, we used a glass of the composition of the Montana Blanca phonolite (MBP) (Table 1) with different concentrations of $\mathrm{Cl}$ and $\mathrm{F}$ as the diffusing elements. The range of diffusion coefficients for $\mathrm{Cl}$ and $\mathrm{F}$ lies between $2 \times 10^{-14}-5 \times 10^{-13} \mathrm{~m}^{2} / \mathrm{s}$ and $5 \times 10^{-13}$ $4 \times 10^{-12} \mathrm{~m}^{2} / \mathrm{s}$, respectively in the temperature range $900-1200{ }^{\circ} \mathrm{C}$ (Böhm and Schmidt 2013), resulting in diffusion that is fast enough to perform experiments within a day and to obtain diffusion profiles with compositional and spatial variations that can be well resolved by electron microprobe. $\mathrm{Cl}$ and $\mathrm{F}$ diffusion is also independent of their concentration (Dingwell and Scarfe 1984; Alleti et al. 2007; Balcone-Boissard et al. 2009) making it easy to analyze the profiles for diffusion modeling. Böhm and Schmidt (2013) have constrained F and Cl diffusion coefficients in nominally dry and hydrous (2.1-2.4 wt\%) Montana Blanca phonolitic (MBP) melt for 800 to $1200{ }^{\circ} \mathrm{C}$, thus making it a suitable medium to carry out our nonisothermal diffusion experiments.

Table 1: Chemical composition of the starting glass of MBP composition obtained using EMP.

\begin{tabular}{ccc}
\hline Oxides & $\mathrm{Wt} \%$ & Standard dev. $(1 \sigma)$ \\
\hline $\mathrm{SiO}_{2}$ & 59.08 & \pm 0.21 \\
$\mathrm{Al}_{2} \mathrm{O}_{3}$ & 18.93 & \pm 0.12 \\
$\mathrm{Na}_{2} \mathrm{O}$ & 10.43 & \pm 0.09 \\
$\mathrm{~K}_{2} \mathrm{O}$ & 5.68 & \pm 0.04 \\
$\mathrm{Fe}_{2} \mathrm{O}_{3}$ & 3.85 & \pm 0.06 \\
$\mathrm{TiO}_{2}$ & 0.67 & \pm 0.03 \\
$\mathrm{MnO}$ & 0.17 & \pm 0.02 \\
$\mathrm{MgO}$ & 0.32 & \pm 0.02 \\
$\mathrm{CaO}$ & 0.83 & \pm 0.03 \\
\hline Total & 99.96 & \\
\hline
\end{tabular}


For the anhydrous halogen-free starting glass, six different oxides $\left(\mathrm{SiO}_{2}, \mathrm{Al}_{2} \mathrm{O}_{3}, \mathrm{Fe}_{2} \mathrm{O}_{3}, \mathrm{TiO}_{2}\right.$, $\left.\mathrm{MnO}_{2}, \mathrm{MgO}\right)$ and three carbonates $\left(\mathrm{Na}_{2} \mathrm{CO}_{3}, \mathrm{~K}_{2} \mathrm{CO}_{3}, \mathrm{CaCO}_{3}\right)$ were mixed together. This mixture was then put into a platinum crucible and was first decarbonated in air at $1000{ }^{\circ} \mathrm{C}$ and then melted in an oven at $1600{ }^{\circ} \mathrm{C}$ and 1 atm pressure. After 30 minutes the melt was quenched to glass by dipping the bottom of the crucible into cold water. A short melting time of 30 min was maintained to minimize Na loss. To obtain a homogenized composition, this glass was ground up to a powder which was again melted. This process was repeated twice.

Glasses with about $0.4 \mathrm{wt} \% \mathrm{Cl}$ and $0.4 \mathrm{wt} \% \mathrm{~F}$ were prepared separately. Cl-rich glass was prepared by adding $\mathrm{NaCl}$ and F-rich glass was prepared by adding $\mathrm{NaF}$ to the to the halogen free MBP glass powder. About $1 \mathrm{~g}$ of each of these mixtures was sealed inside $\mathrm{Au}_{75} \mathrm{Pd}_{25}$ capsules (35 mm length, $6 \mathrm{~mm}$ outer diameter, $0.2 \mathrm{~mm}$ wall thickness), welded shut, pressurized with water for 16 hours in a hydrothermal autoclave to check for possible leaks, and then melted at $1200{ }^{\circ} \mathrm{C}$ and $1.5 \mathrm{kbar}$ pressure for 120 hours in an internally heated pressure vessel (IHPV) to produce bubble free halogen-bearing glass cylinders. The cylinders were cut and polished (down to $1 \mu \mathrm{m}$ ) to rectangular glass blocks of 20x4x1.4 mm. Smaller rectangular blocks of $4 \times 1.6 \times 1.4 \mathrm{~mm}$ were cut out of these large glass blocks using a diamond saw. These blocks are used as individual units in creating diffusive interfaces.

The water contents of the glasses were determined by mid-infrared (MIR) Fourier transform (FT) spectroscopy using a Bruker Vertex 70 spectrometer with attached IR microscope Hyperion 3000. The water content for all the samples was between 0.2 and $0.3 \mathrm{wt} \%$. The anhydrous MBP glass used by Böhm and Schmidt (2013) also contained up to $0.3 \mathrm{wt} \%$ of water. Thus, the diffusivity values given by Böhm and Schmidt (2013) are applicable here without any modifications. 


\subsubsection{Experiments:}

Each F-rich glass block was paired with a Cl-rich glass block and the assemblage was wrapped in a thin Pt foil (0.05 mm thickness), welded shut in a Pt cylinder ( $0.2 \mathrm{~mm}$ thickness, $4 \mathrm{~mm}$ outer diameter and $15 \mathrm{~mm}$ length), and pressurized for 1 hour in a cold seal pressure vessel. The Pt-sheet wrapping and the pressurization ensured a tight contact between the glass blocks across their $1.6 \times 1.4 \mathrm{~mm}$ polished surfaces.

The IHPV was also used for the diffusion experiments. It operated vertically and was equipped with a rapid quench mechanism similar to that of Roux and Lefèvre (1992). The sample capsules were placed in a Pt sample holder that was suspended from a Pt quench wire (0.125-0.15 mm diameter) connected to two electrodes. To avoid internal convection, the capsules were placed in a manner so that the Cl-rich part would be at the bottom. During the experiment, the suspended sample holder was located in the hot spot zone of the furnace, where the thermal variation could be minimized to less than $5{ }^{\circ} \mathrm{C}$ by adjusting the two platinum windings of the furnace. Temperature was recorded by three S-type thermocouples at $\pm 5{ }^{\circ} \mathrm{C}$ accuracy. Pressure was maintained by compressing Ar and recorded by a transducer, calibrated (to \pm 50 bars) against a Heise tube gauge. Heating was isobaric at $40 \pm 2{ }^{\circ} \mathrm{C} / \mathrm{min}$ by constantly increasing the output power over time. Using this procedure, the heating to the final temperature took between 20 and $30 \mathrm{~min}$. Quenching was much faster by fusing the quench wire electrically, which makes the sample drop into the cold bottom part of the vessel $\left(\mathrm{T}<50{ }^{\circ} \mathrm{C}\right)$. The cooling rate in similar experiments was determined to be $\sim 150{ }^{\circ} \mathrm{C} / \mathrm{s}$ by Benne and Behrens (2003).

The experimental set-up was designed to successively create multiple diffusive interfaces (Fig 1). At first, a diffusion couple is heated to a temperature $T_{1}$ (Fig 1a) and maintained at $T_{1}$ for $t_{1}$ amount of time (Fig 1b) and then, rapidly quenched. A second diffusion couple is then added and both couples are heated to another temperature $T_{2}$ (Fig 1c) and maintained for a different duration of $t_{2}$. Both couples are then rapidly quenched at the end of $t_{2}$ (Fig 1d) which marks the closure of diffusion. Fig 2a shows an example (experimental set 1) of the two capsules recovered at the end of $t_{2}$ in one experimental set. The temperature for each experiment varied from 975 to $1150{ }^{\circ} \mathrm{C}$ and duration (run time) for each experiment was between 3 to 7 hours. The samples were recovered to be analyzed for diffusion profiles. The heating and diffusion times were chosen so that the diffusion gradients will remain 
significantly shorter than the half-size of each glass block of the diffusion couples. This allows us to take the two couples as part of the same system where they represent two successive zone boundaries in a crystal. A total of 3 sets of experiments i.e. 6 individual experiments were performed. The diffusion times considered $\left(t_{1}, t_{2}\right)$ are the duration at which the target temperature was maintained, which excludes the duration of heating and cooling. However, diffusive exchange during heating $\left(40^{\circ} \mathrm{C} / \mathrm{min}\right)$ and cooling $\left(150{ }^{\circ} \mathrm{C} / \mathrm{s}\right)$ is small and was corrected for (see below). Experimental conditions of all experiments are listed in Table 2. We used different run durations and temperatures after introducing the second glass sample. Compared to $T_{1}$, the temperature during $t_{2}$, i.e. $T_{2}$, was increased for set 3 and decreased for sets 1 and 2. This was done keeping in mind that in magmatic systems the storage temperature for crystals can either increase or decrease after magma mixing. For example, in the case of a hot mafic recharge, the change in temperature for a crystal residing in colder silicic magma is positive while in the case of a crystal which comes up with the mafic magma that mixes with the shallow colder magma, the change in temperature is negative.

\subsection{Analytical techniques:}

After the termination of the entire experiment, the quenched samples were cut parallel to the diffusion direction at $90^{\circ}$ across the interface between the halogen-rich and halogen-poor blocks and embedded in epoxy resin to be polished for electron microprobe (EMP) analysis (Fig 2a). F and $\mathrm{Cl}$ concentrations were measured together with major elements except oxygen through line analysis across the diffusive boundaries. The lines were set perpendicular to the diffusive interface. Fig $2 \mathrm{~b}$ shows an example of a measured sample (capsule 1 of experimental set 2) in back scattered electron (BSE) image with the former interface and a series of points from quantitative analysis. All analyses were performed with a JEOL JXA $8900 \mathrm{RL}$ at an acceleration voltage of $15 \mathrm{kV}$, a beam current of $15 \mathrm{nA}$, and a beam diameter of 20 and $25 \mu \mathrm{m}$. Major elements were measured with a dwell time of $15 \mathrm{~s}$ on the peak and $5 \mathrm{~s}$ on the background. $\mathrm{F}$ and $\mathrm{Cl}$ were measured with a dwell time of $30 \mathrm{~s}$ on the peak and $15 \mathrm{~s}$ on the background. Topaz was used as a standard for $\mathrm{F}$, synthetic $\mathrm{NaCl}$ for $\mathrm{Cl}$, albite for $\mathrm{Na}$, sanidine for $\mathrm{K}$, hematite for $\mathrm{Fe}$, olivine for $\mathrm{Mg}$, wollastonite for $\mathrm{Ca}$ and $\mathrm{Si}$, synthetic rutile for $\mathrm{Ti}$, rhodonite for $\mathrm{Mn}$ and anorthite for $\mathrm{Al}$. The detection limits for $\mathrm{Cl}$ and $\mathrm{F}$ are $\sim 50 \mathrm{ppm}$ and $\sim 180 \mathrm{ppm}$ respectively. The relative standard deviation $(1 \sigma)$ for $\mathrm{Cl}$ and $\mathrm{F}$ were $<5 \%$ and $<10 \%$. Analytical data for the experimental sets are presented in supplementary material 1. 

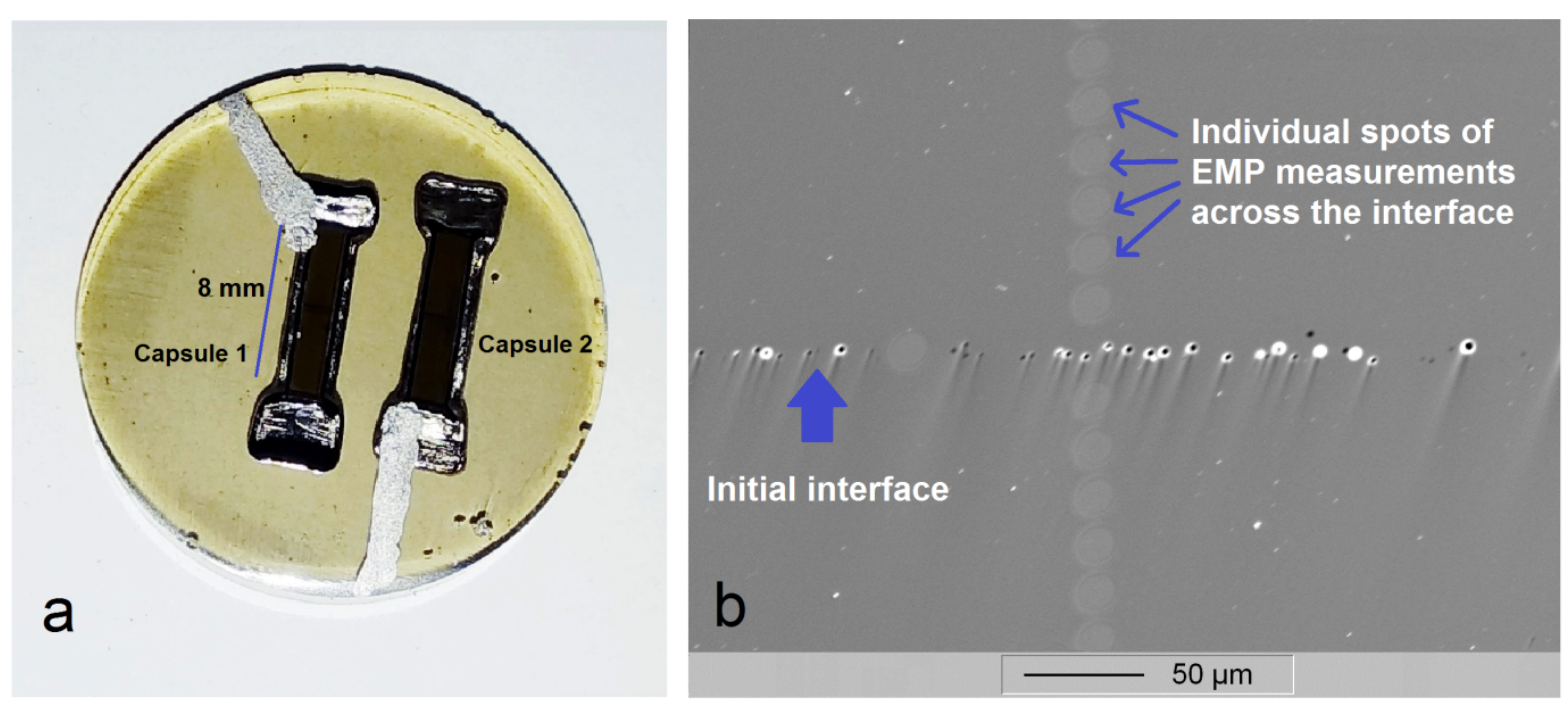

Fig. 2: (a) Example of an experimental set (set 2); quenched samples in epoxy, polished and prepared for EMP. (b) Example of a quantitative line analysis (beam diameter $20 \mu \mathrm{m}$ ) across a diffusion interface (BSE image of capsule 1 of set 2). The initial interface between the two glass blocks is marked by a linear array of bubbles which are formed because of the minuscule amount of trapped air between the polished surfaces of the two initial glass blocks.

EMP measurements were also done on the amphibole inclusions used for thermometry in the sanidine megacryst studied as an application of the model to natural sample. $15 \mathrm{KV}$ accelerating voltage, $15 \mathrm{nA}$ beam current and $10 \mu \mathrm{m}$ beam size were used. Counting times for all the elements were $15 \mathrm{sec}$ on the peak and $5 \mathrm{sec}$ on the background. Calibration standards were olivine for $\mathrm{Si}$ and $\mathrm{Mg}$, albite for $\mathrm{Na}$, anorthite for $\mathrm{Al}$, sanidine for $\mathrm{K}$, hematite for $\mathrm{F}$, $\mathrm{TiO}_{2}$ for $\mathrm{Ti}$, Wollastonite for $\mathrm{Ca}, \mathrm{Cr}_{2} \mathrm{O}_{3}$ for $\mathrm{Cr}$, Rhodonite for $\mathrm{Mn}$ and $\mathrm{NiO}$ for $\mathrm{Ni}$. The relative standard deviation for major oxides was below 5\% and the absolute error calculated for minor oxides was between 0.003 and $0.03 \mathrm{wt} \%$. Accumulated back scattered electron (BSE) images were acquired in COMPO mode with $20 \mathrm{kV}$ accelerating voltage and $20 \mathrm{nA}$ beam current with a slow scanning beam with acquisition time of $120 \mathrm{sec}$ per accumulation. Data from these measurements are presented in supplementary material 2. 


\subsection{Results and discussion:}

\section{Estimating diffusion times in non-isothermal diffusion analysis:}

A least square fitting (with Chi-squared goodness of fit) was applied to model the halogen diffusion profiles (examples given in Fig 3) obtained from EMP analysis to extract the fitting parameters $(\sqrt{ }(4 \mathrm{Dt}))$ and corresponding curve parameters $(\mathrm{Dt})$ for individual profiles. Eq 3 was used as the solution for the diffusion profiles (Crank 1975)

$$
C(x, t)=\frac{\left(C_{\text {high }}+C_{\text {low }}\right)}{2}-\frac{\left(C_{\text {high }}-C_{\text {low }}\right)}{2} \times \operatorname{erf}\left(\frac{\left(x-x_{0}\right)}{\sqrt{4 D t}}\right)
$$

where $C(x, t)$ is the halogen concentration $(w t \%)$ at position $x$ after time $t(s$, experimental duration). $\mathrm{C}_{\text {low }}$ is the initial halogen concentration in the halogen-poor block and $\mathrm{C}_{\text {high }}$ is the initial halogen concentration at the halogen-rich block, D is the diffusion coefficient $\left(\mathrm{mm}^{2} / \mathrm{s}\right)$ and $\mathrm{x}_{0}(\mathrm{~mm})$ is the position ( $\mathrm{x}$-coordinate) of the diffusive interface.

Calculations were done using diffusivity data from Böhm and Schmidt (2013) and the two methods (the algorithm from Petrone et al. (2016) and the alternative curve parameter method) described earlier. These diffusion time estimates (see Table 3) can be compared to the durations of diffusion in the experiments. The calculated durations from the two methods, as expected, were exactly the same and thus, only one set of calculated durations are given in Table 3. However the errors in the diffusion times vary depending on the calculation method used. For the algorithm by Petrone et al. (2016), the error (error 1 in Table 3 ) is $\pm 10-62 \%$ and for the alternative method proposed here, the error is $10-32 \%$. These errors are separately presented in Table 3. They account for the error in fitting based on analytical scatter and the uncertainty in temperature $\left( \pm 5^{\circ} \mathrm{C}\right)$. With the uncertainty in the activation energy $\left(\mathrm{E}_{\mathrm{A}}\right)$ and pre-exponential factor $\left(\mathrm{D}_{0}\right)$ included (which come with the experimental data on diffusivity, Böhm and Schmidt 2013), the error values (error 2 in table 3) increase to $61-288 \%$ for the algorithm of Petrone et al. (2016) and to $60-75 \%$ for the alternative curve parameter method proposed here. 
Table 2: Experimental conditions of all sets of experiments including temperature, pressure, duration or run time and, maximum and minimum halogen content. The run time excludes the durations of heating and cooling.

\begin{tabular}{|c|c|c|c|c|c|c|c|c|c|c|}
\hline \multirow[t]{2}{*}{ Experiment } & \multirow{2}{*}{\multicolumn{2}{|c|}{ Temperature $\left({ }^{\circ} \mathrm{C}\right)$}} & \multirow{2}{*}{$\begin{array}{l}\text { Pressure } \\
\text { (bar) }\end{array}$} & \multicolumn{3}{|c|}{$\begin{array}{c}\text { Experimental } \\
\text { duration/Run time }\end{array}$} & \multicolumn{2}{|c|}{$\begin{array}{c}\text { Chalogen max } \\
\text { (wt\%) }\end{array}$} & \multicolumn{2}{|c|}{$\begin{array}{c}C_{\text {halogen }} \min \\
\text { (wt\%) }\end{array}$} \\
\hline & & & & & seconds & hours & $\mathrm{Cl}$ & $\mathrm{F}$ & $\mathrm{Cl}$ & $\mathrm{F}$ \\
\hline capsule 1 & $\mathrm{~T}_{1}$ & 1085 & 1000 & $\mathrm{t}_{1}$ & 21600 & 6 & 0.42 & 0.39 & 0.00 & 0.00 \\
\hline \multicolumn{11}{|l|}{ Set 1} \\
\hline $\begin{array}{l}\text { capsule } 1+ \\
\text { capsule } 2\end{array}$ & $\mathrm{~T}_{2}$ & 1000 & 1000 & $t_{2}$ & 21600 & 6 & 0.41 & 0.40 & 0.00 & 0.00 \\
\hline capsule 1 & $\mathrm{~T}_{1}$ & 1150 & 1000 & $\mathrm{t}_{1}$ & 10800 & 3 & 0.41 & 0.43 & 0.00 & 0.00 \\
\hline \multicolumn{11}{|l|}{ Set 2} \\
\hline $\begin{array}{c}\text { capsule } 1+ \\
\text { capsule } 2\end{array}$ & $\mathrm{~T}_{2}$ & 1050 & 1000 & $\mathrm{t}_{2}$ & 18000 & 5 & 0.42 & 0.38 & 0.00 & 0.00 \\
\hline capsule 1 & $\mathrm{~T}_{1}$ & 975 & 1000 & $\mathrm{t}_{1}$ & 25200 & 7 & 0.41 & 0.38 & 0.00 & 0.00 \\
\hline \multicolumn{11}{|l|}{ Set 3} \\
\hline $\begin{array}{c}\text { capsule } 1+ \\
\text { capsule } 2\end{array}$ & $\mathrm{~T}_{2}$ & 1120 & 1000 & $t_{2}$ & 12600 & 3.5 & 0.41 & 0.40 & 0.00 & 0.00 \\
\hline
\end{tabular}


The effective diffusion times during the experiment (Table 3) are actually a combination of run duration and diffusion while heating and cooling. We use a new approach in which we analytically estimate the possible additional diffusion during heating and quenching. The heating and cooling rates for the experiments are known and for such a case, an effective diffusion coefficient for the total duration of heating and cooling can be calculated. Mathematically, the condition is defined as

$$
\int_{0}^{t} D d t=D_{e f f} t
$$

where $t$ is the duration of heating or cooling and $D_{\text {eff }}$ is the effective diffusion coefficient for the duration of heating or cooling which is defined as an integral of the varying diffusion coefficient over time. This is similar to the mathematical concept behind NIDIS model

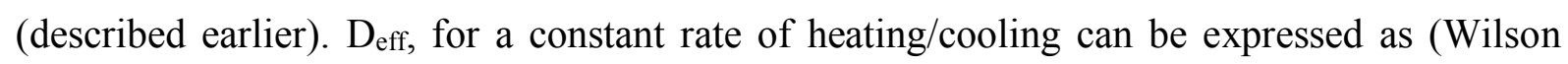
1970)

$$
D_{e f f}=\frac{1}{t}\left(\frac{D_{1} T_{1}^{2}}{\alpha q}-\frac{D_{2} T_{2}^{2}}{\alpha q}\right)
$$

Where $T_{1}$ is the final temperature, $T_{2}$ is the initial temperature, $q$ is $E_{A} / R, \alpha$ is the rate of change in temperature, $D_{1}$ and $D_{2}$ are the diffusion coefficients in the phonolitic melt at $T_{1}$ and $T_{2}$. We take the lower limit of the temperature range for $D_{\text {eff }}$ to be the glass transition temperature for this melt composition $\left(550{ }^{\circ} \mathrm{C}\right.$; Albert 2012), below which diffusion is negligible and the upper limit to be the experimental temperature. Studies by Albert (2012) suggest a glass transition temperature $\left(\mathrm{T}_{\mathrm{g}}\right)$ of $575-600{ }^{\circ} \mathrm{C}$ for the halogen free phonolite melt with 2000-3000 ppm $\mathrm{H}_{2}$ O. $0.4 \mathrm{wt} \% \mathrm{Cl}$ will not affect the $\mathrm{T}_{\mathrm{g}}$ much, while $0.4 \mathrm{wt} \% \mathrm{~F}$ will further reduce $\mathrm{Tg}$ by about $15-20^{\circ} \mathrm{C}$ (Baasner et al. 2013). Thus, we take the $\mathrm{T}_{\mathrm{g}}$ to be $550{ }^{\circ} \mathrm{C}$. In this calculation, we extrapolate the diffusion coefficients down to $550{ }^{\circ} \mathrm{C}$ by assuming an Arrhenius relationship between temperature and diffusion coefficient to continue down to 550 ${ }^{\circ} \mathrm{C}$. Using this extrapolation, we estimated an imaginary effective diffusion profile for heating up to $1200{ }^{\circ} \mathrm{C}$ and obtained a similar diffusion length $(\sim 0.05 \mathrm{~mm}$ for $\mathrm{Cl})$ as for the profiles obtained by Böhm and Schmidt (2013) for their zero time experiment (for heating up to 1200 ${ }^{\circ} \mathrm{C}$ ). This suggests that the extrapolation should be a valid approach. Additionally, the diffusion coefficient for temperatures between 550 and $900{ }^{\circ} \mathrm{C}$ would be much lower than that for experimental temperatures of 975 to $1150{ }^{\circ} \mathrm{C}$. Considering this and the duration of heating, which is very short ( $<8 \%$ of experimental time), any small deviation from Arrhenius behavior between 550 and $900{ }^{\circ} \mathrm{C}$ would be insignificant at a rate of heating of $40{ }^{\circ} \mathrm{C} / \mathrm{min}$ and a cooling rate at $150{ }^{\circ} \mathrm{C} / \mathrm{s}$. Using the effective diffusion coefficient and the duration of heating/cooling, an equivalent time-scale for the additional diffusion is obtained. This 
equivalent additional diffusion time is equivalent to the duration of additional diffusion at the experimental temperature and is given by

$$
t_{\text {additional }}=\frac{D_{\text {eff }} . t}{D_{\text {experimental }}}
$$

where $D_{\text {experimental }}$ is the diffusion coefficient during the experimental run-time (calculated using experimental temperature and data from Böhm and Schmidt 2013). The values of $D_{\text {eff, }}$ $D_{\text {efft }}$ and $t_{\text {additional }}$ are presented in supplementary material 1 . The additional diffusion time ( $\left.\mathrm{t}_{\text {additional }}\right)$ is added to the experimental duration to obtain the total effective diffusion time, which is compared against the calculated diffusion times from the diffusion profiles. The additional diffusion time, accounting only for heating, ranges from 78 to 279 seconds $(0.022-$ 0.077 hours) for all diffusive boundaries of both $\mathrm{Cl}$ and $\mathrm{F}$. Rapid quenching, however, accounts for a maximum of only 1 second ( 0.00034 hours) of additional time. The maximum estimated total additional diffusion that occurred in experimental set 2 (at $1150{ }^{\circ} \mathrm{C}$ and total run time for $\mathrm{T}_{1}$ of 3 hours or 10800 seconds) for $\mathrm{F}$ accounts for an extra 0.077 hours or 280 seconds $(2.6 \%)$.

Our results (Table 3) show that the estimated diffusion times match well with the actual values of $t_{1}$ and $t_{2}$ of the experiment. The deviation of calculated values from actual values is between $1.1 \%$ and $18.2 \%$. This suggests that the non-isothermal diffusion incremental step model works for crystals with multiple zonation provided the temperature during the growth of each zone is well-constrained and the times of changing temperature is relatively short (less than $8 \%$ of total diffusion times). For a case where diffusivity is dependent on other factors e.g. pressure or oxygen fugacity (e.g. Fe-Mg diffusion in olivine, Dohmen and Chakraborty 2007), constraining these factors during the course of the crystal growth will also be necessary to apply the model effectively. 

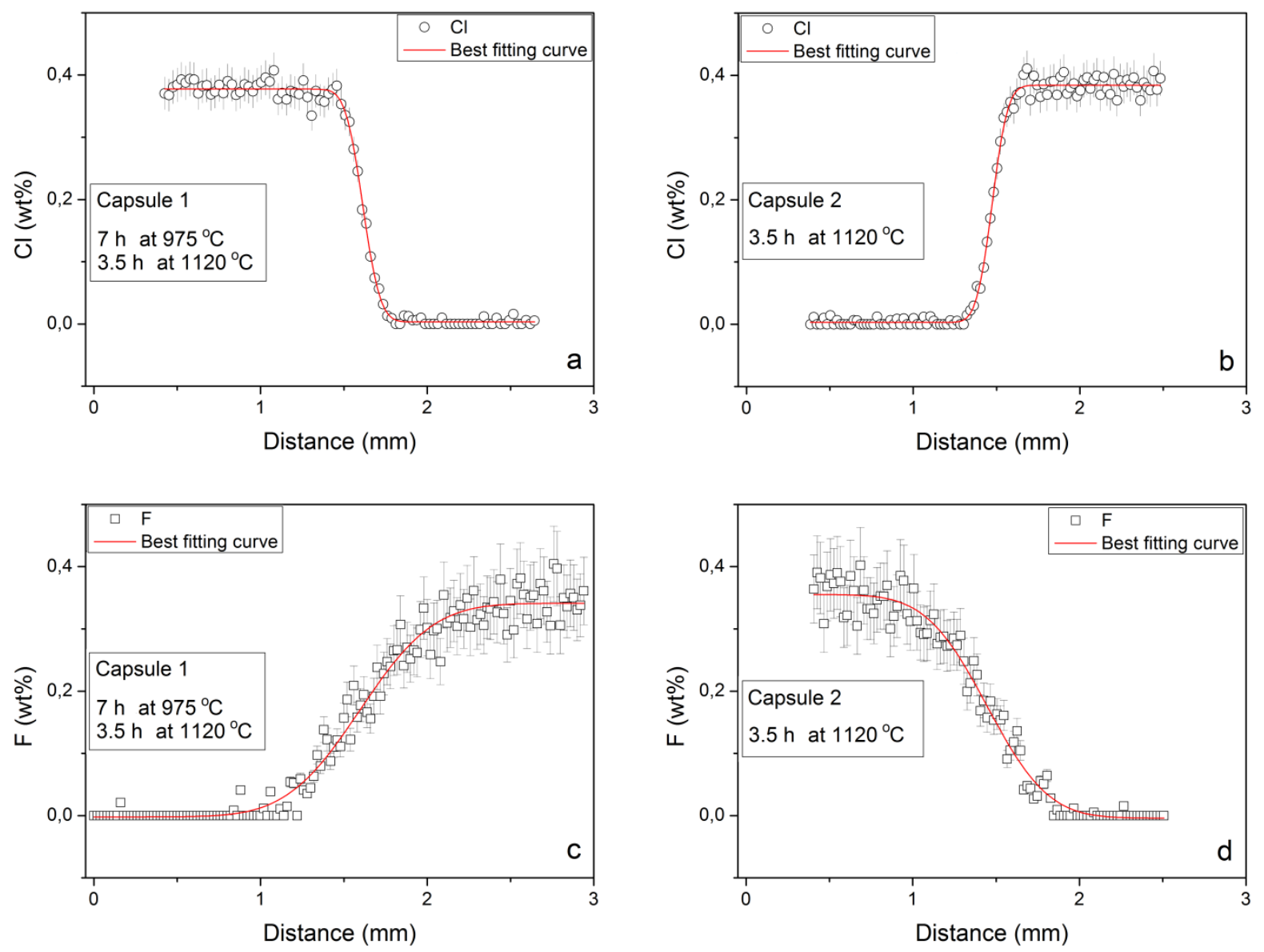

Fig. 3: Halogen diffusion profiles obtained by EMP from the capsules set 3 of experiments. (a) $\mathrm{Cl}$ and (c) $\mathrm{F}$ (wt\%) profiles in capsule 1 of the experimental set that represents the core-mantle boundary. (b) $\mathrm{Cl}$ and (d) $\mathrm{F}$ (wt $\%$ ) profiles in capsule 2 of the experimental set that represents the mantle-rim boundary. The solid red lines are the calculated model curves used for fitting.

\section{Estimating errors in non-isothermal diffusion modeling:}

The maximum observed deviations between calculated and experimental diffusion times for $\mathrm{F}$ are $18.2 \%$ for capsule 2 of set 2 and $7.8 \%$ for capsule 1 of set 3 . This is mostly because of the higher scatter in F contents due to the higher analytical uncertainty of the electron microprobe for light elements. The detection limit for $\mathrm{F}$ is $180 \mathrm{ppm}$ (compared to $50 \mathrm{ppm}$ for $\mathrm{Cl}$ ) and the relative standard deviation (at $2 \sigma$ ) for $\mathrm{F}$ is $\sim 15 \%$ (compared to $\sim 7 \%$ for $\mathrm{Cl}$ ). The scatter in the data points is within the uncertainty of $\pm 15 \%$.

Here we have designed the experiments equivalent to a crystal with only two diffusive boundaries within three growth zones of a crystal. The NIDIS model for calculating diffusion times can be extended to more than two diffusive boundaries following an equivalent algorithm where the calculations start backwards from the outer most rim and end at the core. 
To assess the total error on individual diffusion time estimates, the sources of contributing errors need to be constrained. These are the same for both the NIDIS algorithm proposed by Petrone et al. (2016) and the alternative curve parameter method described in this study. However, the algorithm presented by Petrone et al. (2016) does not consider uncertainties in the diffusivity parameters $\left(\mathrm{E}_{\mathrm{A}}\right.$ and $\left.\mathrm{D}_{0}\right)$. Therefore, in order to allow direct comparison against the algorithm by Petrone et al. (2016), error 1 (Table 3) is estimated which deliberately excludes uncertainties in $\mathrm{E}_{\mathrm{A}}$ and $\mathrm{D}_{0}$, as discussed in detail in this section. However, an error, which includes uncertainties in $\mathrm{E}_{\mathrm{A}}$ and $\mathrm{D}_{0}$, is also estimated, presented separately in Table 3, and discussed later in this section. Here, we use the absolute error values from the curve parameter method to first discuss the major sources and their contribution, and then compare them individually to those from the NIDIS algorithm.

The error due to the uncertainty in temperature is significant in diffusive analysis (Costa and Morgan 2010) because of the exponential relationship between the diffusion coefficient and temperature (Eq 1). In our experiments the uncertainty is up to $\pm 5^{\circ} \mathrm{C}$ which accounts for \pm 3 $7 \%$ error in estimated diffusion times and constitutes up to $\sim 55 \%$ of the total error (error 1 ). However, in natural samples where the temperature values are estimated using thermometric calculations, uncertainty of $\pm 15-20{ }^{\circ} \mathrm{C}$ and more is inevitable. For example, an uncertainty of $\pm 20{ }^{\circ} \mathrm{C}$ during $\mathrm{Cl}$ and $\mathrm{F}$ diffusion in phonolite melt will transfer into an error of $15-27 \%$ in calculated diffusion times. For elements with higher activation energy (e.g. Ba and Sr; Cherniak 2010), the error can be up to $70 \%$ for a temperature of $1000{ }^{\circ} \mathrm{C}$. Petrone et al. (2016) applied their NIDIS model to Fe-Mg diffusion in clinopyroxene and report an error of $35-40 \%$ in total residence time estimates for a temperature uncertainty of $10-15{ }^{\circ} \mathrm{C}$. The propagated error (at 95\% confidence level) in the first step of diffusion is even higher (60$100 \%$ ). The error decreases by more than $50-70 \%$ if the uncertainty in temperature is ignored. Thus, precisely constraining the different temperatures turns out to be the most vital requirement for applying non-isothermal diffusive analysis (Petrone et al. 2016).

A second source of error is the error in curve fitting which contributes significantly to the total error as well. In our measurements, the error due to curve fitting accounts for $\sim 45-80 \%$ of the total error (error 1$)$. Although this can be reduced with more precise analytical techniques, even small percentages of error can accumulate to give a significantly large error as we go backwards from rim to core in the NIDIS modeling approach. For example, using a 
simple error propagation method in analyses of 3 diffusive boundaries, each with $20 \%$ error in curve fitting, we get a propagated error of $40 \%$ in the diffusion time for the inner-most boundary. Thus, it is essential to consider the propagation of error in the application of the NIDIS model. However, the propagation of error can be reduced significantly if we apply the alternative curve parameter method. In that case, for each diffusive boundary, the curve parameter for that boundary will be subtracted by that of the next boundary and the result will be used to estimate the specific time-scale. For each step of calculation, only 2 curve parameters will be involved and the errors from the rest of the boundaries will not have an effect. This will lower the uncertainty in individual diffusion time calculations and eventually in the total diffusion time. For instance, in the example above, every individual diffusion time calculated (except for the outer-most boundary) will have a lower error of only $\sim 28 \%$. This is in contrast to the NIDIS algorithm given by Petrone et al. (2016), where the time-scales from all the previously (starting from rim) analyzed diffusion boundaries are used to estimate the diffusion time for a particular boundary.

Another advantage of the curve parameter method over the algorithm given by Petrone et al. (2016) is that the contribution of uncertainty in temperature to the error in individual (except for the outer most) and total diffusion time is significantly limited. If we take for example a crystal with 2 diffusive boundaries, then for the core-mantle boundary, $\mathrm{t}_{1}$ is obtained as $\left(\mathrm{CP}_{1}-\right.$ $\mathrm{CP}_{2}$ )/ $\mathrm{D}_{1}$. In this case, the uncertainty in temperature contributes only once through $\mathrm{D}_{1}$ (which is obtained using $\mathrm{T}_{1}$ ). This stays true even for a crystal with multiple number of diffusive boundaries where $t_{n}=\left(C_{n}-C P_{n+1}\right) / D_{n}$. Conversely, the algorithm given by Petrone et al. (2016), calculates $t_{1}$ as the difference between the imaginary time-scales $t_{3}$ and $t_{4}$, both of which are calculated from each of the two fitting parameters $(\sqrt{4} \mathrm{Dt}$ from curve fitting) using $\mathrm{D}_{1}$ individually. In that case, the uncertainty in temperature contributes twice to the error in calculated diffusion time.

To demonstrate the differences between the two algorithms, we calculated the diffusion times for the halogen profiles also using the algorithm by Petrone et al. (2016). The error obtained is 
Chapter 4: Constraints on non-isothermal diffusion modeling: an experimental analysis and error assessment using halogen diffusion in melts

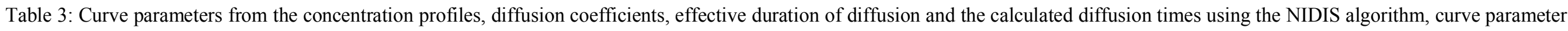

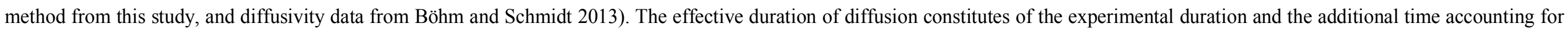
the diffusion that happened during heating and cooling. The errors in the calculated diffusion times account for the error in curve fitting and the uncertainty in temperature.

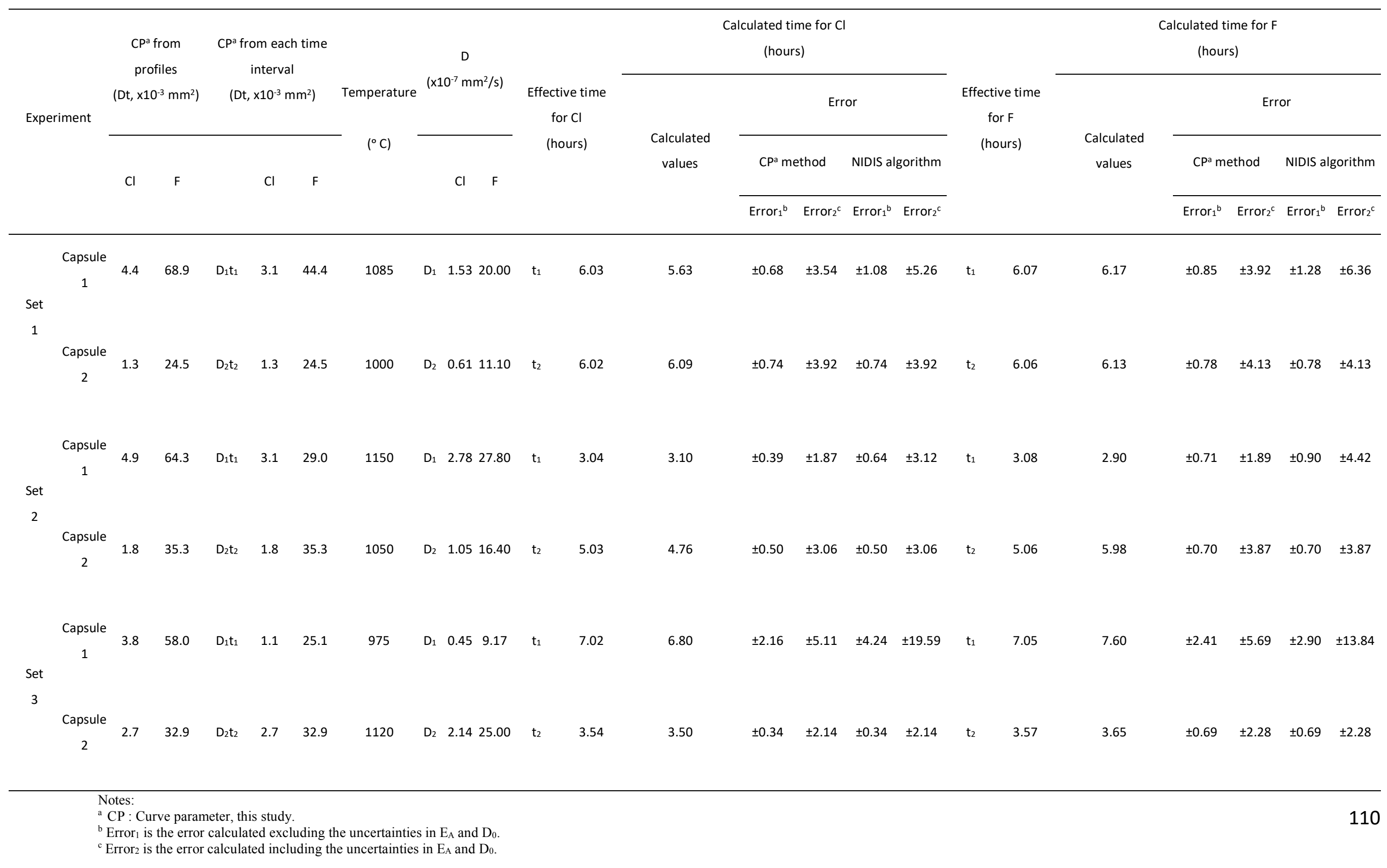


$60-100 \%$ higher for $\mathrm{Cl}$ and $20-51 \%$ higher for $\mathrm{F}$ in values of $\mathrm{t}_{1}$ compared to the error obtained using our new alternative algorithm (Table 3). The error in the total time scales was also increased by $28-94 \%$ for $\mathrm{Cl}$ and $14-30 \%$ for $\mathrm{F}$. Except for the error in $\mathrm{t}_{1}$ and $\mathrm{t}$, the values for $t_{1}, t_{2}$ and $t$ are the same in both the methods, which is expected as both the methods are mathematically consistent. The errors for $t_{2}$ are also the same as both the methods use a basic curve fitting of the rim-mantle boundary and $\mathrm{D}_{2}$ to obtain $\mathrm{t}_{2}$. The difference in errors is higher for $\mathrm{Cl}$ compared to $\mathrm{F}$ because $\mathrm{Cl}$ has a higher activation energy $(153 \mathrm{~kJ} / \mathrm{mol})$ compared to $\mathrm{F}$ $(99.8 \mathrm{~kJ} / \mathrm{mol})$ (Böhm and Schmidt 2013). A higher activation energy will yield a higher total fraction of error (see Appendix 1).

We used the data given by Petrone et al. (2016) for multiple zoned clinopyroxene crystals from Stromboli volcano (Italy) to re-estimate the diffusion time with our new algorithm. The results (Table 4) show that the curve parameter method yields $26-40 \%$ error $(2 \sigma)$ in $t_{1}$ compared to the original $61-100 \%$ error $(2 \sigma)$ given by Petrone et al. (2016). The error in the total diffusion time is also slightly less (33-38\% compared to $36-40 \%)$. The difference in the error in the total diffusion time is less because the difference only occurs in $t_{1}$, which in this case, is very small (only $1 / 10$ to $1 / 4$ of $t_{2}$ ). As the error in $t_{2}$ remains the same from both the methods and because $t_{2}$ is much longer than $t_{1}$, the total error does not change much in this case, although the difference is very large for $t_{1}$. However, the value of the non-isothermal diffusion model lies in its ability to estimate $t_{1}$ and thus, the error in $t_{1}$ is extremely vital and should be minimized. These differences in the error in diffusion time are for a temperature uncertainty of 15 and $10{ }^{\circ} \mathrm{C}$ as reported by Petrone et al. (2016) at 1098 and $1150{ }^{\circ} \mathrm{C}$ respectively. The difference in the error obtained by both the methods will be even higher for temperature values with higher uncertainty and/or for elements with higher activation energies for diffusion.

A third source of uncertainty is the uncertainty associated with diffusivity parameters (activation energy $\mathrm{E}_{\mathrm{A}}$ and pre-exponential factor $\mathrm{D}_{0}$ ). These come directly from experimentally determined data and are generally unavoidable. We use the uncertainties given by Böhm and Schmidt (2013) $\left(\sim 7.5 \mathrm{~kJ} / \mathrm{mol}\right.$ in $\mathrm{E}_{\mathrm{A}}$ and $1.2 \times 10^{-8}-1.3 \times 10^{-7} \mathrm{~m}^{2} / \mathrm{s}$ in $\mathrm{D}_{0}$ for both $\mathrm{F}$ and $\mathrm{Cl}$ ). When included, it can constitute up to $57-84 \%$ of the total error (error 2 in Table 3 ). Petrone et al. (2016), however, had not considered this source of error. To analyze the difference between the two algorithms, we incorporated this uncertainty into the algorithm by Petrone et al. (2016) and estimated the error on the diffusion times in our samples. The 
difference between the errors from the curve parameter and the algorithm by Petrone et al. (2016) is even higher, when uncertainties in $\mathrm{E}_{\mathrm{A}}$ and $\mathrm{D}_{0}$ are included. The curve parameter method yields only $60-75 \%$ error in contrast to $61-288 \%$ of the NIDIS algorithm by Petrone et al. (2016). This is because, like temperature, the contributions of uncertainties in $E_{A}$ and $D_{0}$ are limited to only once in the curve parameter method, whereas in the algorithm by Petrone et al. (2016), they contribute to the error in each imaginary duration individually, thus contributing more than once to every diffusion time (except for the outer-most boundary).

Another source of uncertainty is the rate of temperature change between, and within distinct diffusion intervals. The present non-isothermal diffusion model assumes that temperature follows an ideal step function with (1) negligible periods of temperature change and (2) constant temperatures between the temperature changes. The assumption of constant temperature between temperature changes is hardly applicable for natural samples where, after a sharp heating event, the temperature may again decrease slowly due to cooling until the next heating event occurs. Such a saw tooth pattern in the temperature history is indeed evident in crystals that had long storage times and underwent growth and resorption (for examples see Cooper and Kent 2014; Rubin et al. 2017; Ginibre et al. 2007). Moreover, the assumption of instantaneous temperature change might also not always be valid. For example, for strong and short heating events (like in the models by Cooper and Kent 2014; Rubin et al. 2017; Ginibre et al. 2007), although the short duration of heating might be negligible for long duration of diffusion of slow elements like $\mathrm{Ba}$ and $\mathrm{Sr}$ (Cherniak 2010), it will be significant for short duration of diffusion of faster elements. For example, a fast diffusing element like Li (8-9 orders of magnitude faster than $\mathrm{Ba}$ and $\mathrm{Sr}$ in feldspars, Cherniak 2010) in a rapidly evolving, high-temperature mafic system with very short crystal residence times (weeks to months) will be affected even by heating intervals as short as a few days. This can also be seen in the calculated additional diffusion times (supplementary material 1) accounting for the time the samples spent during heating and quenching in our experiment. These additional times for $\mathrm{F}$ are $\geq 2$ times higher than those of $\mathrm{Cl}$ for the exact same duration of heating and quenching. Such scenarios will make the assumption of (1) isothermal periods between (2) instantaneous temperature change invalid. In such complicated cases, the non-isothermal incremental step model can still be applied, however, for the modeling of individual diffusion boundaries, the changes in temperature variations during the diffusion process also need to be taken into account. This can be achieved using effective diffusion coefficients (Eq. 4 and Eq. 5) and following the same procedure (described earlier) as used to estimate the extra time 
Table 4: Comparison of error in diffusion timescales of the 4 clinopyroxene crystals (from Stromboli volcano, Italy) studied by Petrone et al. (2016) using the alternative curve parameter method from this study against the values given by Petrone et al. (2016). The error in $\mathrm{t}_{1}, \mathrm{t}_{2}$ and total $\mathrm{t}$, calculated using the method described in this study, comprises of the $2 \sigma$ in both fitting parameter and temperature as given by Petrone et al. 2016. The crystal cpx1 from Petrone et al. (2016) is not mentioned here as it has only 1 diffusive boundary which reduces it to a normal diffusion analysis and the non-isothermal model is not applicable.

\begin{tabular}{|c|c|c|c|c|c|c|c|c|c|c|c|c|}
\hline \multirow[b]{2}{*}{ Crystal } & \multicolumn{12}{|c|}{ Calculated time and errors (yr) } \\
\hline & $\begin{array}{c}\text { t1 } \\
\text { (Petrone et } \\
\text { al. 2016) }\end{array}$ & $\begin{array}{c}\mathrm{t} 1 \\
\text { (this study) }\end{array}$ & $\begin{array}{c}\text { error in t1 } \\
(2 \sigma, \text { Petrone } \\
\text { et al. 2016) }\end{array}$ & $\begin{array}{c}\text { error in } \mathrm{t} 1 \\
(2 \sigma, \text { this } \\
\text { study })\end{array}$ & $\begin{array}{c}\text { t2 } \\
\text { (Petrone et } \\
\text { al. 2016) }\end{array}$ & $\begin{array}{c}\mathrm{t} 2 \\
\text { (this study) }\end{array}$ & $\begin{array}{l}\text { error in t2 } \\
(2 \sigma, \text { Petrone } \\
\text { et al. 2016) }\end{array}$ & $\begin{array}{c}\text { error in t2 } \\
(2 \sigma, \text { this } \\
\text { study) }\end{array}$ & $\begin{array}{c}\text { total t } \\
\text { (Petrone et } \\
\text { al. 2016) }\end{array}$ & $\begin{array}{c}\text { total t } \\
\text { (this study) }\end{array}$ & 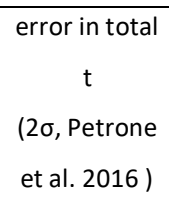 & $\begin{array}{c}\text { error in total } \\
t \\
(2 \sigma, \text { this } \\
\text { study) }\end{array}$ \\
\hline $\mathrm{cpx2}$ & 0.2 & 0.2 & 0.2 & 0.05 & 1.6 & 1.6 & 0.6 & 0.6 & 1.8 & 1.8 & 0.7 & 0.6 \\
\hline $\mathrm{cpx3}$ & 0.6 & 0.6 & 0.6 & 0.24 & 4.2 & 4.2 & 1.8 & 1.8 & 4.8 & 4.8 & 1.9 & 1.8 \\
\hline $\operatorname{cpx} 4$ & 1.4 & 1.4 & 1.2 & 0.43 & 9.2 & 9.2 & 3.7 & 3.7 & 10.6 & 10.6 & 3.9 & 3.6 \\
\hline cp $55^{*}$ & 2.3 & 2.3 & 1.4 & 0.60 & 9.5 & 9.5 & 3.9 & 3.9 & 11.8 & 11.8 & 4.2 & 3.9 \\
\hline
\end{tabular}

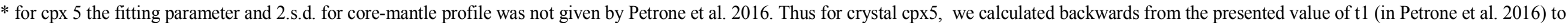
obtain corresponding fitting parameter and assummed a $10 \% 2$ s.d. (in line with the mantle-rim profile) and calculated t1 again using the method mentioned in this study. 
accounting for additional diffusion during heating and quenching, if the cooling or heating rate is well-constrained. However, for most cases, especially in silicic systems, where crystal residence lasts for thousands to hundreds of thousands of years (Morgan and Blake 2006), short periods of heating (up to a few years) would be insignificant. Secondly, for most cases where magmatic differentiation is interrupted by recharge events, the temperature differences between distinct growth zones will be much larger than the temperature variation during growth between the abrupt events of temperature change. In these cases, the regular nonisothermal incremental step model can still be efficient in extracting the pre-eruptive history of a growing magmatic crystal. 


\section{Application to other natural samples:}
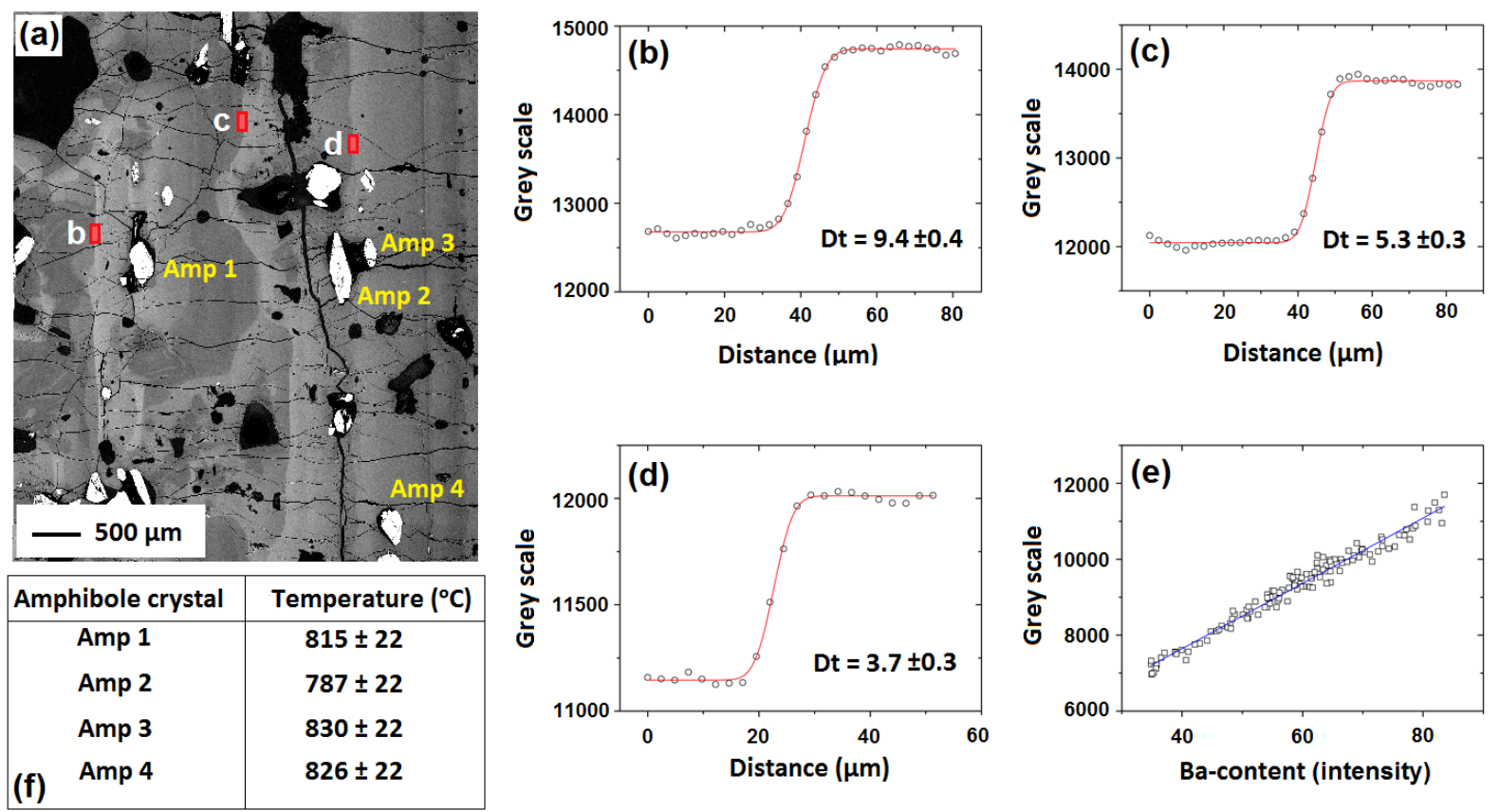

Fig. 4: (a) BSE image of the analyzed sanidine megacryst from Taapaca volcano (N. Chile). The three zones in the megacryst are separated by the three boundaries b, c and d. (b), (c) and (d) are the grey-scale profiles at boundaries $b$, c and $d$, respectively. The solid red curves are the modeled diffusion curves obtained through curve fitting. The red squares in (a) denote the areas over which these profiles are taken. (e) Correlation between grey-scale values and Ba-content in the megacryst. Amphibole (Amp) inclusions within the zones in (a) yield (f) temperatures (using thermometer by Ridolfi et al. 2010) specific to each inclusion, thus specific to each zone. The error in the temperature is $1 \sigma$.

We are not aware of published studies that would allow to further test the non-isothermal modeling due to (1) lack of individual temperature data for different growth and diffusion intervals of the crystals (e.g. Zellmer et al. 1999; Costa et al. 2003; Zellmer and Clavero 2006; Chamberlain et al. 2014) and (2) lack of (or lack of data on) multiple zone boundaries (e.g. Costa et al. 2003; Chamberlain et al. 2014; Costa and Dungan 2005; Costa and Chakraborty 2004; Ackerson et al. 2018; Iovine et al. 2017).

Therefore, we demonstrate such a test based on our own data on a sanidine megacryst (Fig 4) from a Late Pleistocene to Holocene eruption stage (0.45 Ma - present; Clavero et al. 2004b) of Taapaca volcano (N. Chile). Zellmer and Clavero (2006) applied isothermal diffusion analysis to a similar sanidine megacryst from this volcano and estimated diffusion times ranging from 0.5 to $1.3 \mathrm{ky}$. Such sanidine megacrysts (Banaszak 2007), present in every eruption stage of Taapaca volcano, are compositionally and texturally very similar (Banaszak 
2014). This allows us to analyze one of the megacrysts for non-isothermal diffusion modeling and compare the results to isothermal analysis (Zellmer and Clavero 2006).

The analyzed megacryst (Fig 4) consists of 3 significant Ba-zonations separated by resorption surfaces, which are ideal to apply diffusion chronometry as they ensure an initial sharp compositional profile to start with. Each zone contains amphibole and plagioclase inclusions (Fig 4a) that allow to constrain the temperature during the growth of each zone. We applied the thermometer given by Ridolfi et al. (2010) to the amphibole inclusions and obtained temperatures between 787 and $830^{\circ} \mathrm{C}$. After verifying an apparent linear relationship between grey-scale values from BSE images and Ba-content (Fig 4e, further details in supplementary material 2) in the crystal, we used grey-scale values as proxy for Ba-content and extracted grey-scale profiles (Fig 4b, c and d) to be used for Ba-diffusion modeling. The data for this analysis are given in supplementary material 2. We used the Ba diffusivity data given by Cherniak (2002) $\left(\mathrm{Ea}=455000 \mathrm{~J} / \mathrm{mol}\right.$ and $\left.\mathrm{D}_{0}=0.29 \mathrm{~m}^{2} / \mathrm{s}\right)$ and applied the non-isothermal diffusive analysis (both NIDIS algorithm and curve parameter method). For comparison we also modeled the profiles for isothermal diffusion at 787 and $830{ }^{\circ} \mathrm{C}$, the minimum and the maximum temperatures obtained from thermometry.

The calculated diffusion times are presented in Table 5. It is evident that the non-isothermal diffusion, which takes temperature specific to each zone into account, returns significantly different individual and total diffusion times compared to isothermal calculation. The diffusion times of $1.5-9.4 \mathrm{ky}$ are also different from the isothermal diffusion times of $0.5-1.3$ ky obtained by Zellmer and Clavero (2006) at $875{ }^{\circ} \mathrm{C}$. If they had used a more realistic albeit constant temperature value, e.g. between 787 and $830^{\circ} \mathrm{C}$, their diffusion time estimate would have been much longer. It is also evident that, as shown earlier, although both the curve parameter method and the NIDIS algorithm obtain the same diffusion times, the curve parameter method returns a significantly lower error (67-108\%) compared to the original NIDIS algorithm of Petrone et al. (2016) (100-352\%). Apart from the accuracy of curve parameter method, this analysis shows that if the temperature-time history across several growth and diffusion zones can be constrained, the non-isothermal analysis gives more robust and significantly different total diffusion time-scale compared to traditional isothermal analysis. 
Table 5: Obtained individual and total diffusion times from the sanidine megacryst using isothermal and non-isothermal diffusion modeling. The errors in all the diffusion times are $1 \sigma$ and comprise of uncertainty in temperature $\left( \pm 22^{\circ} \mathrm{C}\right)$ and errors in curve fitting.

\begin{tabular}{|c|c|c|c|c|c|c|c|c|c|c|c|}
\hline Zone & $\mathrm{T}\left({ }^{\circ} \mathrm{C}\right)$ & \multicolumn{2}{|c|}{$\begin{array}{l}\text { Isothermal diffusion } \\
\text { time at } 787^{\circ} \mathrm{C} \\
\text { (yr) }\end{array}$} & \multicolumn{2}{|c|}{$\begin{array}{c}\text { Isothermal diffusion } \\
\text { time at } 830^{\circ} \mathrm{C} \\
\text { (yr) }\end{array}$} & \multicolumn{2}{|c|}{$\begin{array}{l}\text { Diffusion time } \\
\text { NIDIS algorithm } \\
(\mathrm{yr})\end{array}$} & \multicolumn{2}{|c|}{$\begin{array}{l}\text { Diffusion time } \\
\mathrm{CP}^{\mathrm{a}} \text { method } \\
(\mathrm{yr})\end{array}$} & \multirow[t]{2}{*}{$\begin{array}{l}\text { Relative error } \\
\text { NIDIS algorithm } \\
\text { (\%) }\end{array}$} & $\begin{array}{l}\text { Relative errol } \\
\mathrm{CP}^{\mathrm{a}} \text { method } \\
(\%)\end{array}$ \\
\hline$b$ & $815 \pm 22$ & 11900 & \pm 12800 & 1.6 & \pm 1.6 & 3.1 & \pm 8.6 & 3.1 & \pm 3.2 & & 103 \\
\hline c & $787 \pm 22$ & 4800 & \pm 5200 & 0.6 & \pm 0.6 & 4.8 & \pm 16.9 & 4.8 & \pm 5.2 & 352 & 108 \\
\hline$d$ & $830 \pm 22$ & 11000 & \pm 11800 & 1.5 & \pm 1.5 & 1.5 & \pm 1.5 & 1.5 & \pm 1.5 & 100 & 100 \\
\hline $\begin{array}{l}\text { Total } \\
\text { time }\end{array}$ & & 27700 & \pm 18200 & 3.7 & \pm 2.2 & 9.4 & \pm 19 & 9.4 & \pm 6.3 & 202 & 67 \\
\hline
\end{tabular}

Notes:

a CP: Curve parameter, this study. 


\subsection{Implications}

As argued above, the non-isothermal diffusion modeling of magmatic crystals with multiple diffusion interfaces at multiple resorption interfaces should result in more realistic diffusion and residence time estimates revealing valuable information for complexly zoned crystals, provided the temperature is properly constrained. For example, Petrone et al. (2016) inferred from the model that the Stromboli magma system is a well-mixed reservoir where the inputs of fresh magma are rapidly (within $\sim 1-2$ years) homogenized within the resident magma. Such detailed information cannot be extracted using isothermal diffusive analysis. Our own analysis of the Taapaca sanidine megacryst also shows that the non-isothermal diffusion model provides more reliable information for crystals that show highly complex zonation and resorption patterns with respect to total diffusion times, crystal residence times and the history of magmatic process prior to eruption.

However, the potential pitfalls due to accumulating effects of errors and insufficient precision on constrained temperature histories and not-so-perfect curve-fitting must be realized. This limits the use of the modified NIDIS model to only a few well-constrained cases where T-t history can be constrained.

The increased focus on methods of geothermo- and barometry in magmatic systems (e.g. Putirka 2008; Ridolfi et al. 2010; Mutch et al. 2016; Sun and Liang 2017; Reverdatto et al. 2019) should improve and enable us to use the non-isothermal diffusion in future studies. The improved assessment of errors in this study provides detail on the extent to which major errors (e.g. due to temperature uncertainty, curve fitting and diffusivity data) can propagate and how to minimize them. Considering errors realistically is necessary to use the model, for natural systems and to constrain the validity, advantages and limitations of the non-isothermal diffusion. Beyond the application to zoned crystals in magmatic systems, the improved approach to the NIDIS algorithm can also be applied to diffusional mass transport processes in general, as the underlying principle will remain the same. 
Acknowledgements: This study is a part of the doctoral research project funded by a scholarship from Deutscher Akademischer Austauschdienst (DAAD) to S. S. Rout. We thank A. Kronz for his support during electron microprobe analysis and B. Schlieper-Ludewig for her assistance during the initial glass preparation. We also appreciate the effort of D. Baker (editor), C Lesher (associate editor) and two anonymous reviewers whose comments and suggestions have helped in improving the manuscript.

\subsection{References}

Ackerson MR, Mysen BO, Tailby ND, Watson EB (2018) Low-temperature crystallization of granites and the implications for crustal magmatism. Nature 559:94-97.

Albert C (2012) Experimentelle Bestimmung der Viskosität wasserhaltiger Phonolithschmelzen, Diploma thesis, Georg-August Universität, Göttingen (in German).

Alletti M, Baker DR, Freda C (2007) Halogen diffusion in a basaltic melt. Geochimica et Cosmochimica Acta 71:3570-3580.

Baasner A, Schmidt BC, Webb SL (2013) The effect of chlorine, fluorine and water on the viscosity of aluminosilicate melts. Chemical Geololgy 357:134-149.

Balcone-Boissard H, Baker DR, Villemant B, Boudon G (2009) F and Cl diffusion in phonolitic melts: influence of the $\mathrm{Na} / \mathrm{K}$ ratio. Chemical Geology 263:89-98.

Banaszak M (2007) Kristallisationsbedingungen und Barium-Zonierung von Sanidinen in Magmen des Taapaca Vulkans, Nord Chile. Diplomarbeit, Georg-August Universität, Göttingen.

Banaszak M (2014) Differentiation regimes in the Central Andean magma systems: case studies of Taapaca and Parinacota volcanoes, Northern Chile, PhD thesis, Georg-August Universität, Göttingen.

Befus KS, Watkins J, Gardner JE, Richard D et al. (2015) Spherulites as in-situ recorders of thermal history in lava flows. Geology 43:647-650.

Benne D, Behrens H (2003) Water solubility in haplobasaltic melts. European Journal of Mineralogy 15:803-814.

Bloch E, Ganguly J (2014) 176Lu-176Hf and 147Sm-143Nd ages of the Martian shergottites: Evaluation of the shock-resetting hypothesis through diffusion kinetic experiments and modeling, and petrological observations. Earth and Planetary Science Letters 395:173-183.

Böhm A, Schmidt BC (2013) Fluorine and chlorine diffusion in phonolitic melt. Chemical Geology 346:162-171.

Chakraborty S (2008) Diffusion in solid silicates: a tool to track timescales of processes comes of age. Annual Review of Earth and Planetary Sciences 36:153-190. 
Chamberlain KJ, Morgan DJ, Wilson CJN (2014) Timescales of mixing and mobilisation in the Bishop Tuff magma body: perspectives from diffusion chronometry. Contributions to Mineralogy and Petrology 167:1034.

Cherniak DJ (2002) Ba diffusion in feldspar. Geochimica et Cosmochimica Acta, 66:1641-1650.

Cherniak DJ (2010) Cation diffusion in feldspars. In Y. Zhang, and D.J. Cherniak, Eds, Diffusion in Minerals and Melts, 72, p. 691-733. Reviews in Mineralogy and Geochemistry, Mineralogical Society of America and Geochemical Society.

Clavero JE, Sparks RSJ, Pringle MS, Polanco E, Gardeweg M (2004b.) Evolution of Taapaca Volcanic Complex, Central Andes of Northern Chile. Journal of the Geological Society 161:603-618.

Condomines M, Hemond C, Allegre CJ (1988) U-Th-Ra radioactive disequilibria and magmatic processes. Earth and Planetary Science Letters 90:243-262.

Cooper KM, Reid MR, Murrell MT, Clague DA (2001) Crystal and magma residence times at Kilauea Volcano, Hawaii: 230Th-226Ra dating of the 1955 east rift eruption. Earth and Planetary Science Letters 184:703-718.

Cooper KM, Kent AJR (2014) Rapid remobilization of magmatic crystals kept in cold storage. Nature 506:480-483.

Costa F, Chakraborty S (2004) Decadal time gaps between mafic intrusion and silicic eruption obtained from chemical zoning patterns in olivine. Earth and Planetary Science Letters 227:517-530.

Costa F, Chakraborty S, Dohmen R (2003) Diffusion coupling between trace and major elements and a model for calculation of magma residence times using plagioclase. Geochimica et Cosmochimica Acta 67:2189-2200.

Costa F, Dohmen R, Chakraborty S (2008) Time scales of magmatic processes from modelling the zoning patterns of crystals. In K.D. Putirka and F.J. Tepley, III, Eds, Minerals, Inclusions and Volcanic Processes, 69, p. 545-594. Reviews in Mineralogy and Geochemistry, Mineralogical Society of America and Geochemical Society.

Costa F, Dungan M (2005) Short time scales of magmatic assimilation from diffusion modeling of multiple elements in olivine. Geology 33:837-840.

Costa F, Morgan D (2010) Time constraints from chemical equilibration in magmatic crystals. In A. Dosseto, S.P. Turner and J.A. Van Orman, Eds, Timescales of magmatic processes: from core to atmosphere. John Wiley \& Sons, Ltd, Chichester, UK. doi: 10.1002/9781444328509.ch7

Crank J (1975) The Mathematics of Diffusion. Clarendon-Oxford, London.

Dingwell DB, Scarfe CM (1984) Chemical diffusion of fluorine in jadeite melt at high pressure. Geochimica et Cosmochimica Acta 48:2517-2525. 
Dohmen R, Chakraborty S (2007) Fe-Mg diffusion in olivine II: point defect chemistry, change of diffusion mechanisms and a model for calculation of diffusion coefficients in natural olivine. Physics and Chemistry of Minerals 34:409-430.

Ganguly J, Dasgupta S, Cheng W, Neogi S (2000) Exhumation history of a section of the Sikkim Himalayas, India: records in the metamorphic mineral equilibria and compositional zoning of garnet. Earth and Planetary Science Letters 193:471-486.

Gardner JE, Befus KS, Watkins J, Hesse M, Miller N (2012) Compositional gradients surrounding spherulites in obsidian and their relationship to spherulite growth and lava cooling. Bulletin of Volcanology 74:1865-1879.

Ginibre C, Wörner G, Kronz A (2004) Structure and Dynamics of the Laacher See Magma Chamber (Eifel, Germany) from Major and Trace Element Zoning in Sanidine: a Cathodoluminescence and Electron Microprobe Study. Journal of Petrology 45:2197-2223.

Ginibre C, Wörner G, Kronz A (2007) Crystal zoning as archives for magma evolution. ELEMENTS 3:261-166.

Hawkesworth CJ, Blake S, Evans P et al. (2000) Time scales of crystal fractionation in magma chambers-integrating physical, isotopic and geochemical perspectives. Journal of Petrology 41:991-1006.

Hawkesworth C, George R, Turner S, Zellmer G (2004) Time scales of magmatic processes. Earth and Planetary Science Letters 218:1-16.

Holland T, Blundy J (1994) Non-ideal interactions in calcic amphiboles and their bearing on amphibole- plagioclase thermometry. Contributions to Mineralogy and Petrology 116:433447.

Iovine RS, Fedele L, Mazzeo FC, Arienzo I, Cavallo A, Wörner G, Orsi G, Civetta L, D’Antonio M (2017) Timescales of magmatic processes prior to the 4.7 ka Agnano-Monte Spina eruption (Campi Flegrei caldera, Southern Italy) based on diffusion chronometry from sanidine phenocrysts, Bulletin of Volcanology 79:18.

Johnson MC, Rutherford MJ (1989) Experimental calibration of the aluminum-in-hornblende geobarometer with application to Long Valley caldera (California). Geology 17:837-841.

Lasaga A (1983) Geospeedometry: an extension of geothermometry. In S.K. Saxena, Eds, Kinetics and Equilibrium in Mineral Reactions, 2, p. 81-114. Advances in Physical Geochemistry, Springer, New York.

Morgan DJ, Blake S (2006) Magmatic residence times of zoned phenocrysts: introduction and application of the binary element diffusion modelling (BEDM) technique. Contributions to Mineralogy and Petrology 151:58-70.

Morgan DJ, Blake S, Rogers NW, DeVivo B, Rolandi G, Macdonald R, Hawkesworth CJ (2004) Time scales of crystal residence and magma chamber volumes from modelling of diffusion profiles in phenocrysts: Vesuvius 1944. Earth and Planetary Science Letters 222:933-946. 
Mutch EJF, Blundy JD, Tattitch BC, Cooper FJ, Brooker RA (2016) An experimental study of amphibole stability in low-pressure granitic magmas and a revised Al-in-hornblende geobarometer. Contributions to Mineralogy and Petrology 171:85.

Petrone CM, Bugatti G, Braschi E, Tommasini S (2016) Pre-eruptive magmatic processes re-timed using a non-isothermal approach to magma chamber dynamics. Nature communications $7: 12946$.

Putirka K (2008) Thermometers and Barometers for Volcanic Systems. In K. Putirka and F. Tepley, Eds, Minerals, Inclusions and Volcanic Processes, 69, p. 61-120. Reviews in Mineralogy and Geochemistry, Mineralogical Society of America and Geochemical Society.

Reid MR (2003) Timescales of magma transfer and storage in the crust. In R.L. Rudnick, Ed, The Crust, Treatise on Geochemistry 3, p. 167-193. Elsevier, Oxford.

Reverdatto VV, Likhanov II, Polyansky OP, Sheplev VS, Kolobov VY (2019) Mineral Geothermobarometry. In The Nature and Models of Metamorphism. Springer Geology. Springer, Cham.

Ridolfi F, Renzulli A, Puerini M (2010) Stability and chemical equilibrium of amphibole in calcalkaline magmas: an overview, new thermobarometric formulations and application to subduction-related volcanoes. Contributions to Mineralogy and Petrology 160:45-66.

Roux J, Lefèvre A (1992) A fast-quench device for internally heated pressure vessels. European Journal of Mineralogy 4:279-281.

Rubin AE, Cooper KM, Till CB, Kent AJR et al. (2017) Rapid cooling and cold storage in a silicic magma reservoir recorded in individual crystals. Science 356:1154-1156.

Ruprecht P, Wörner G (2007) Variable regimes in magma systems documented in plagioclase zoning patterns: El Misti stratovolcano and Andagua monogenetic cones (S. Peru). Journal of Volcanology and Geothermal Research 165:142-162.

Saal AE, Hauri EH, Lo Cascio M et al. (2008) Volatile content of lunar volcanic glasses and the presence of water in the Moon's interior. Nature 454:192-196

Schmitt AK (2011) Uranium series accessory crystal dating of magmatic processes. Annual Review of Earth and Planet Sciences 39:321-349.

Sun C, Liang Y (2017) A REE-in-plagioclase-clinopyroxene thermometer for crustal rocks. Contributions to Mineralogy and Petrology 172:24.

Watson EB, Müller T (2009) Non-equilibrium isotopic and elemental fractionation during diffusioncontrolled crystal growth under static and dynamic conditions. Chemical geology 267:111124.

Wilson PR (1970) A solution to the diffusion equation for non isothermal diffusion. Solid-State Electronics 13:1311-1313. 
Zellmer GF, Blake S, Vance D, Hawkesworth C, Turner S (1999) Short plagioclase residence times at two island arc volcanoes (Kameni islands, Santorini, and Soufriere, St. Vincent) determined by Sr diffusion systematics. Contributions to Mineralogy and Petrology 136:345-357.

Zellmer GF, Clavero JE (2006) Using trace element correlation patterns to decipher a sanidine crystal growth chronology: An example from Taapaca volcano, Central Andes. Journal of Volcanology and Geothermal Research 156:291-301.

Zellmer G, Turner S, Hawkesworth C (2000) Timescales of destructive plate margin magmatism: new insights from Santorini, Aegean volcanic arc. Earth and Planetary Science Letters 174:265281.

\subsection{Appendix}

The relative error propagation on the time-scale obtained from the modeling of each diffusion profile is calculated as follows:

$$
\frac{\sigma_{t}}{t}=\sqrt{\left\{\left(\frac{E_{A}}{R T}\right)^{2}\left[\left(\frac{\sigma_{E_{A}}}{E_{A}}\right)^{2}+\left(\frac{\sigma_{T}}{T}\right)^{2}\right]+\left(\frac{\sigma_{\sqrt{4 D t}}}{\sqrt{4 D t}}\right)^{2}+\left(\sigma_{\ln \left|D_{0}\right|}\right)^{2}\right\}}
$$

where $t$ is diffusion time (s), $\sigma_{t}$ is the error in diffusion time, $E_{A}$ is the activation energy, $\sigma_{\mathrm{E}_{\mathrm{A}}}$ is the error in activation energy, $\mathrm{R}$ is the universal gas constant, $\mathrm{T}$ is the temperature, $\sigma_{\mathrm{T}}$ is the uncertainty in temperature, $\mathrm{D}$ is the diffusion coefficient, $\sigma_{\sqrt{4 \mathrm{Dt}}}$ is the error in curve fitting, $\mathrm{D}_{0}$ is the pre-exponential factor and $\sigma_{\ln \left|\mathrm{D}_{0}\right|}$ is the uncertainty in $\ln \left(\mathrm{D}_{0}\right) \cdot \sigma_{\sqrt{4 D t}}$ is the standard error on ' $\sqrt{ }(4 \mathrm{Dt})$ ' obtained by using ' $\sqrt{ }(4 \mathrm{Dt})$ ' as a single parameter in the curve fitting. For the curve fitting, predefined fitting functions in OriginLab were used which use Chi-Square tolerance value of $1 \times 10^{-9}$ for an acceptable fit. In the presented results, in error 1 , the term $\sigma_{\mathrm{E}_{\mathrm{A}}}$ and $\sigma_{\ln \left|\mathrm{D}_{0}\right|}$ are ignored as we compare against the results and algorithm presented by Petrone et al. 2016 who have not considered these errors. However, these are important sources of error that come directly from the experimental data on diffusivity. These uncertainties are

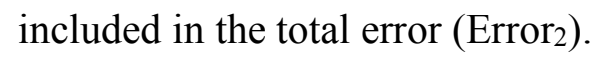




\title{
Chapter 5: Pre-eruptive history of Taapaca volcano (N. Chile) constrained by non-isothermal diffusion chronometry on sanidine megacrysts
}

\author{
Smruti Sourav Rout ${ }^{a}$, Magdalena Blum-Oeste ${ }^{\mathrm{a} *}$, Gerhard Wörner ${ }^{\text {a }}$
}

a Geowissenschaftliches Zentrum, Georg-August-Universität (GZG), a* Previously at Geowissenschaftliches Zentrum, Georg-August-Universität (GZG), Goldschmidtstrasse 1, 37077 Göttingen, Germany

\begin{abstract}
:
Sanidine megacrysts of unusual size (up to $12 \mathrm{~cm}$ ), derived from a ryholite magma occur in hybrid dacite magmas with abundant mafic enclaves at Taapaca volcano (Central volcanic Zone, $18^{\circ}, \mathrm{N}$. Chile). These sanidines are strongly zoned in $\mathrm{Ba}$, rich in mineral and glass inclusions and occur throughout the entire eruptive history (1.5 Ma to Recent). Nonisothermal diffusion modeling of Ba concentration gradients on the multiple growth zones in the sanidine megacrysts of hybrid dacite samples from Taapaca volcano (Northern Chile) is used to estimate crystal residence and reactivation times prior to eruption. We observe sharp jumps in Ba-concentration across resorption interfaces that reflect distinct heating events, suggesting that different growth zones formed at different temperatures. Amphiboleplagioclase thermo-barometry gave temperatures of $\sim 720-820{ }^{\circ} \mathrm{C}$ and pressures of $1-3 \mathrm{kbar}$ for each growth zone separately. Using these temperatures, Ba-profiles from x-ray scanning profiles and grey scale gradients based on accumulated BSE images were modeled to obtain diffusion times for individual diffusive boundaries ranging from 0.4 to $490 \mathrm{ky}$ that add up to total residence times of 9 to $499 \mathrm{ky}$ for different crystals from different stages of eruption. A combination of temperatures, pressure, diffusion times and modeling of the parent rhyodacite using R-melts suggests storage of a crystal mush (crystallinity $>40-50 \mathrm{vol} \%$ ) at near eutectic composition and temperatures $\left(\geq 720^{\circ} \mathrm{C}\right)$ for tens to hundreds of thousands of years at shallow depth $(4-10 \mathrm{~km})$. Frequent recharges of basaltic andesite magma kept the reservoir thermally 'alive' and caused multiple heating and resorption events within the crystals. Recharge events became more frequent $\left(\sim 0.33-0.67 \mathrm{ky}^{-1}\right)$ and sped up only $\sim 3-11 \mathrm{ky}$ before each eruption that carried the sanidine megacrysts to the surface. Thus, after many earlier recharges that did not
\end{abstract}


result in eruption, a last event eventually caused mixing at a critical recharge rate to mobilize, entrain, and erupt the megacrysts from the resident rhyodacite in a hybrid dacite host. This process has been repeated at similar timescales at different stratigraphic stages throughout the 1.5 Ma long history of Taapca volcano.

Keywords: Taapaca volcanic complex, Non-isothermal diffusion, Thermo-barometry, Badiffusion, crystal mush

\subsection{Introduction:}

Constraining rates of magmatic processes, time-scales and conditions of crystal residence and storage of magmas are the key to constrain the pre-eruptive history of magma systems. Such studies serve as essential tools in understanding potentially dangerous and active volcanoes, and help in eruption forecasting, hazard assessment and risk management. Some of the most hazardous volcanoes are silicic volcanoes which have relatively long eruption histories with low eruption frequencies that can erupt with no or little anticipation (e.g. 2008 rhyolitic eruption of Chaitén volcano, Chile; Alfano et al. 2011, Saubin et al. 2016). Such volcanoes apparently are fed from reservoirs with extended evolution histories that can store magmas of variable crystallinity for hundreds to thousands of years. Yet the time to accumulate and (re-) activate large eruptible magma volumes may be relatively short (Cooper and Kent 2014; Bachmann and Bergantz 2008; Rubin et al. 2017) compared to the total storage time. This has led to new concepts for the evolution of silicic magma systems, where magmas are stored as non-eruptible crystal mushes for longer times that may become eruptible relatively fast via recharge-induced heating and mush reactivation, leading to the formation of large volumes of less-viscous eruptible magma prior to eruption (Bachmann and Bergantz 2008; Reid 2008; Ellis et al. 2014; Cooper and Kent 2014; Barboni et al. 2016; Annen et al. 2008; Huber et al. 2012).

During storage, evolution and activation of magma reservoirs, the associated temperature, pressure and compositional changes are imprinted in the composition of growth zones in the minerals that crystallize from the magmas (Chakraborty 2008; Costa and Chakraborty 2004; Morgan and Blake 2006; Costa and Morgan 2010; Ginibre et al. 2007). In order to constrain the rates of these processes controlling the evolution and eruption of magmatic systems and their crystals, two principal methods have been developed in the past two decades. One is the (1) direct dating of crystals by short-lived U-series isotopes (e.g. Hawkesworth et al. 2000; 
Hawkesworth et al. 2004; Schmitt 2011; Condomines et al. 1988) that provides insights into their time of formation relative to eruption times and thus gives the minimum age of magmas, respectively crystal mushes. For example, 230Th-226Ra dating applied to Santorini (Zellmer et al. 2000) and Kilauea Volcanoes, Hawaii (Cooper et al. 2001), and applications of U-Th-Ra disequilibria to MORB and OIB (Condomines et al. 1988) constrain time-scales of fractional crystallization, magma transport and residence from hundreds up to hundreds of thousands of years. A second method (2) is the estimation of pre-eruptive residence time of crystals using diffusion speedometry of zoned phenocrysts which has been applied, for example, to plagioclase (Zellmer et al. 1999; Costa et al. 2003), pyroxene (Morgan et al. 2004; Chamberlain et al. 2014), olivine (Costa and Dungan 2005; Costa and Chakraborty 2004), quartz (Chamberlain et al. 2014) and sanidine (Chamberlain et al. 2014; Iovine et al. 2017). While the former approach gives arbitrary results because crystal ages (from cold, locked-up mushes) do not reflect the age of eruptible magmas, the latter suffers from uncertainties in defining the temperature of the diffusion process and possible changes in temperature during crystal growth and residence.

Cooper and Kent (2014) summarized and combined these methods and compared diffusion ages to U-series ages for a large range of small to large, mafic to evolved magma systems. Particularly for long-lived silicic systems, it appears that diffusion times, obtained for a temperature well above diffusion threshold are invariably less than absolute crystal ages recorded by U/Th isotopes. Apparently, the crystals must have spent a significant portion of their "life" at low temperatures where diffusion is negligible. Thus, interpreting residence times from modeling of diffusion gradients critically depends on the thermal history of a crystal which can be constrained using various thermometers (e.g. Holland and Blundy 1994; Johnson and Rutherford 1989; Ridolfi et al. 2010). Only if thermal history suggests that the crystals spent most of their storage time well above the diffusion threshold, and this temperature is well-constrained, then the diffusion times will be same as residence times and diffusion chronometry will give robust results (e.g. Morgan and Blake, 2006).

In this study, we apply diffusion modeling to xenocrystic sanidines entrained in dacites from Taapaca volcano (Nothern Chile) which has more than a million years of eruption history (Kohlbach and Lohnert 1999; Clavero et al. 2004). During this time, the volcano has only produced uniform, crystal-rich hybrid dacites with abundant mafic enclaves (Blum-Oeste \& Wörner, 2016) and large sanidine megacrysts (Zellmer and Clavero 2006). The uniformitiy of 
erupted products, and the long eruption history indicate relatively long storage histories. The sanidine megacrysts show complex zonation patterns in $\mathrm{Ba}$ with abundant resorption interfaces, their size and frequency of mineral inclusions, including plagioclase and amphibole, which allow to estimate crystallization temperatures for each growth zone. This permits diffusion modeling of each analysed zone boundary using the specific temperature obtained from that particular zone, which is only possible - but also particularly interesting for such unique sanidine crystals of this large size from a volcanic host. Such non-isothermal diffusion modeling (Petrone et al. 2016; Rout et al. 2019) should give more reliable diffusion time estimates than using only one diffusion temperature for the entire crystal and their growth history. Our data also allow to better trace cold vs. hot storage conditions in evolved arc magma systems and constrain the origin of zoned potassium feldspar megacrysts that are otherwise only known, and strongly debated, from granites (Johnson and Glazner 2010; Vernon 1986; Glazner and Boudreau 2011; Slaby et al. 2008; Holness et al. 2018 ).

\subsection{Geology and Petrography:}

\subsubsection{Geological setting:}

Taapaca Volcanic Complex (TVC; 5824m, $18^{\circ} \mathrm{S}, 69^{\circ} \mathrm{W}$ ), also known as Nevados de Putre, is located in the Central Volcanic Zone of the Andes between latitudes $14^{\circ}$ and $28{ }^{\circ} \mathrm{S}$ (Fig. 1) where the Nazca oceanic plate subducts beneath the South American plate. The Quaternary Andean volcanic activity occurs in four segments, the Northern, Central, Southern and Austral volcanic zones, which are separated by volcanic gaps (Thorpe et al. 1982).

The TVC is part of the Western Cordillera, which comprises the NW-SE Quaternary volcanic chain at the border between Chile and Bolivia and lies to the $\mathrm{W}$ of the Altiplano Plateau, the largest non-collisional orogenic plateau on Earth (Isacks, 1988). The region is characterized by high topography with numerous active volcanoes exceeding elevation of $6000 \mathrm{~m}$ asl. Taapaca is somewhat unusual as it lies about $30 \mathrm{~km}$ to the west of the main volcanic chain of the central part of the CVZ.

The 'modern' cycle of active continental margin magmatism in the Central Andes started around $180 \mathrm{Ma}$. Jurassic intrusive and extrusive igneous arc rocks are exposed in the Coastal Cordillera at the present coast. The focus of volcanism migrated from the coastal Cordillera in 
the west to east to the Altiplano between Jurassic and Miocene times (e.g. Scheuber et al. 1994; Wörner et al. 2018). The present active volcanic front is located at the western margin of the Altiplano. Reasons for arc migration are debated and could be due to massive tectonic erosion in the forearc and shallowing of the subduction angle. Presently, the subducting slab descends below the CVZ at a relatively shallow angle of $\sim 25$ to $30^{\circ}$ (Cahill and Isacks 1992) and a convergence rate of $75-80 \mathrm{~mm} / \mathrm{a}$ (Samoza 1998). The volcanic front of the CVZ lies approximately $120-150 \mathrm{~km}$ above the subducted slab and remarkably thick continental crust (>70 km) below the Altiplano region (James 1971; Zandt et al. 1994; Allmendinger et al. 1997; Scheuber and Giese 1999; Yuan et al. 2002; Tassara et al. 2006).

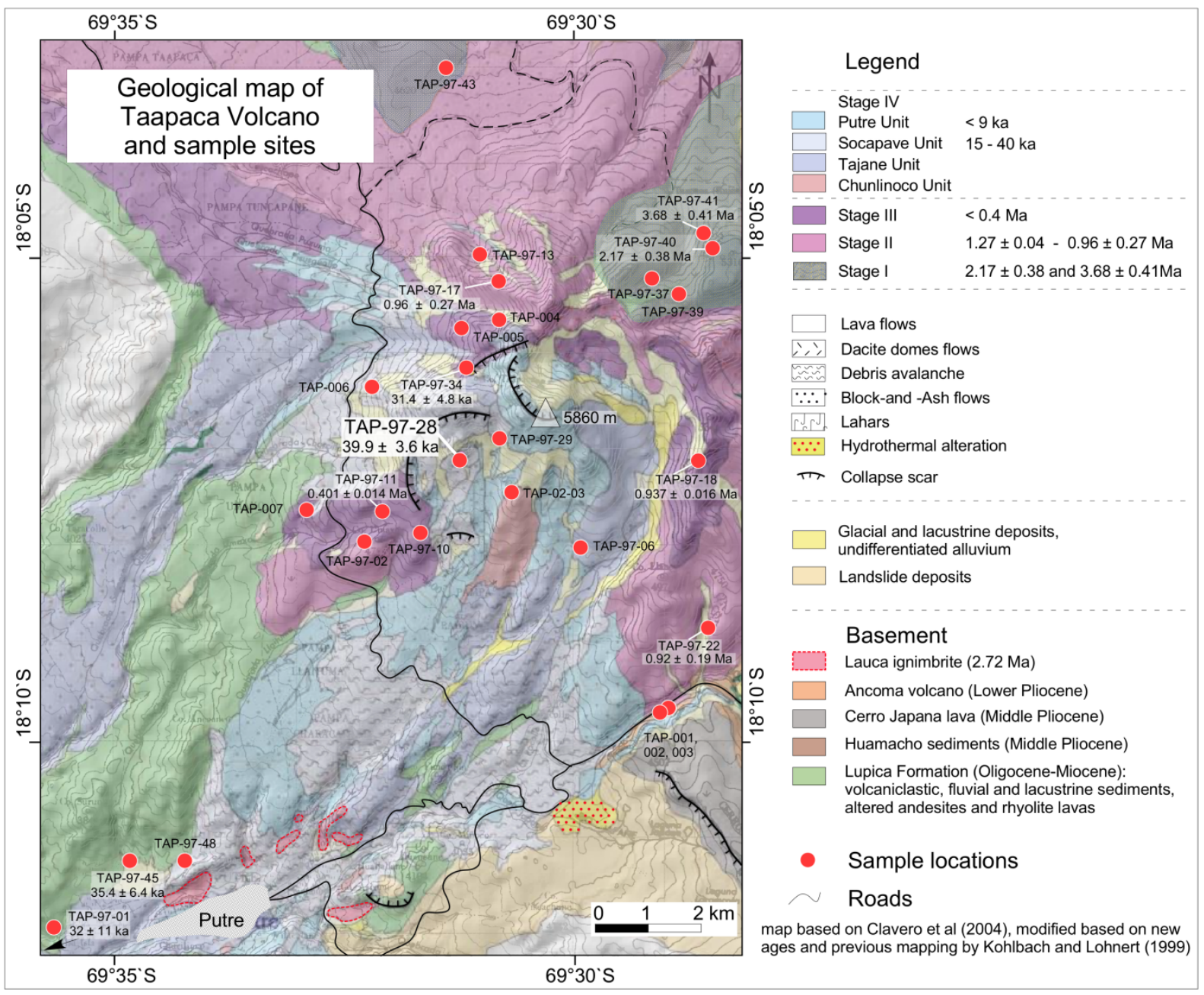

Fig 1. Simplified geological map of the Taapaca Volcanic Complex with locations of samples, adapted from Clavero et al. (2004).

The crust below the Altiplano consists of Palaeoproterozoic (2.0-1.8 Ga) Arequipa terrane represented by metamorphic and igneous rocks exposed in southern Peru and in a series of inliers in N Chile and W Bolivia (Loewy et al. 2004; McLeod et al. 2013). Proterozoic 
amphibolites and gneisses of metamorphic Belen Complex exposed in northernmost Chile along the Chilean Precordillera just $35 \mathrm{~km}$ to the $\mathrm{S}$ of Taapaca volcano, and granulites and charnockites of Cerro Uyarani on the western Altiplano as reported by Wörner et al. (2000) are equivalents to the basement rocks underlying the $\mathrm{CVZ}$ in northern Chile.

\subsubsection{History and compositions of lavas erupted at Taapaca volcano:}

The eruptive history of the TVC, previously described by Kohlbach \& Lohnert (1999) who identified three stages of evolution based on contact relationships, mineral mode, flow morphology and vent location. These stages have been refined further and presented in detail by Clavero et al. (2004), who recognized four evolutionary stages based on geochronological and morphological criteria, events of gravitational sector collapse and subsequent migration of the main vents (Fig. 1). In this study, we have used the classification of stratigraphy and eruption stages given by Clavero et al. 2004 .

The volcanic edifice of Taapaca is partly constructed on a deeply eroded topography on the western margin of the Cordillera and consists of elongated dome clusters with three exposed summit domes of which the highest reaches $5850 \mathrm{~m}$ asl. The main edifice volume is estimated to be $35 \mathrm{~km}^{3}$; the eruptive products of Taapaca cover an area of $250 \mathrm{~km}^{2}$ (Clavero et al. 2004). The volcano is directly underlain by the $2.7 \mathrm{Ma}$ Lauca ignimbrite (Wörner et al. 2000), Miocene andesitic lava flows, and the Upper Oligocene - Lower Miocene Lupica Formation.

The initial eruptive stage (Stage I) formed a gently-dipping stratovolacano consisting of moderately porphyritic two-pyroxene andesitic lava flows $\left(\sim 60 \mathrm{wt} \% \mathrm{SiO}_{2}\right)$ containing small amounts of sanidine and hornblende. Stage I is estimated to be older than 1.5 Ma. Stage II forms the main volume of TVC, extends from 1.5 to $0.5 \mathrm{Ma}$. The oldest ${ }^{40} \mathrm{Ar} /{ }^{39} \mathrm{Ar}$ age from the earliest stage II samples is at $1.46 \pm 0.07 \mathrm{Ma}$ (Clavero et al. 2004). It consists of viscous dacitic lava flows, which formed a steeply-dipping stratovolcano. A major collapse event is documented within stage II by a voluminous debris avalanche. Stage III (0.5 - $0.47 \mathrm{Ma})$ consists of small volume lava domes and block-and-ash flow deposits concentrated mainly in the central part of the dome complex. The eruptive products differ from stage II only by higher amounts of sanidine megacrysts and mafic enclaves. Partial collapse of the southern part of ancestral stage II edifice and stage III domes marks the start of the youngest and morphologically most complex stage IV (0.45 Ma - recent). The dacites generated during Late-Pleistocene - Holocene eruptive activity of TVC are petrographically undistinguishable from those of unit III. Stage IV forms the main central edifice of TVC, characterized by 
extrusion of voluminous domes and associated block-and-ash flows, blast deposits, tephra fallout, pyroclastic flows, debris avalanche, and lahars. The pyroclastic flows, surges, and tephra fallout are associated with dome growth-collapse explosions.

Numerous debris avalanche deposits are evidence for frequent edifice collapse events at TVC. Clavero et al. (2004) recognized two types of debris avalanche at Taapaca: (1) debris avalanches that are a consequence of extensive hydrothermal alteration causing edifice weakening, and (2) by intrusion of a cryptodome causing deformation and instability of the edifice. The latter collapse triggering mechanism is evident from blast deposits integrated in the debris avalanche, which results from a rapid decompression after abrupt mass unloading. Despite the catastrophic mass unload events observed at TVC, a change in the composition and mineralogy of erupting products after edifice collapses has not been observed.

All dacites from stage II to IV contain sanidine megacrysts, plagioclase, amphibole and biotite phenocrysts, rare quartz and titanite, and very rare, small anhedral clinopyroxene. Mafic enclaves comprise up to 6 vol\% of the dacite. Abundance and size of both, mafic enclaves and sanidine megacrysts increase from stage II through IV of the eruptive history of Taapaca volcano.

Whole rock chemical compositions (Fig. 2) of dacites that were erupted at Taapaca vary little throughout the entire 1.5 Ma history of this volcano. Therefore, Taapaca dacites are unusullay uniform compared nearby Parinacota volcano that shows a much larger compositional range in $\mathrm{SiO}_{2}(52-76 \%)$ from basalt to rhyolite (Blum-Oeste and Wörner 2016, Clavero et al. 2002; 2004; Wörner et al. 1988; Hora et al. 2007). 


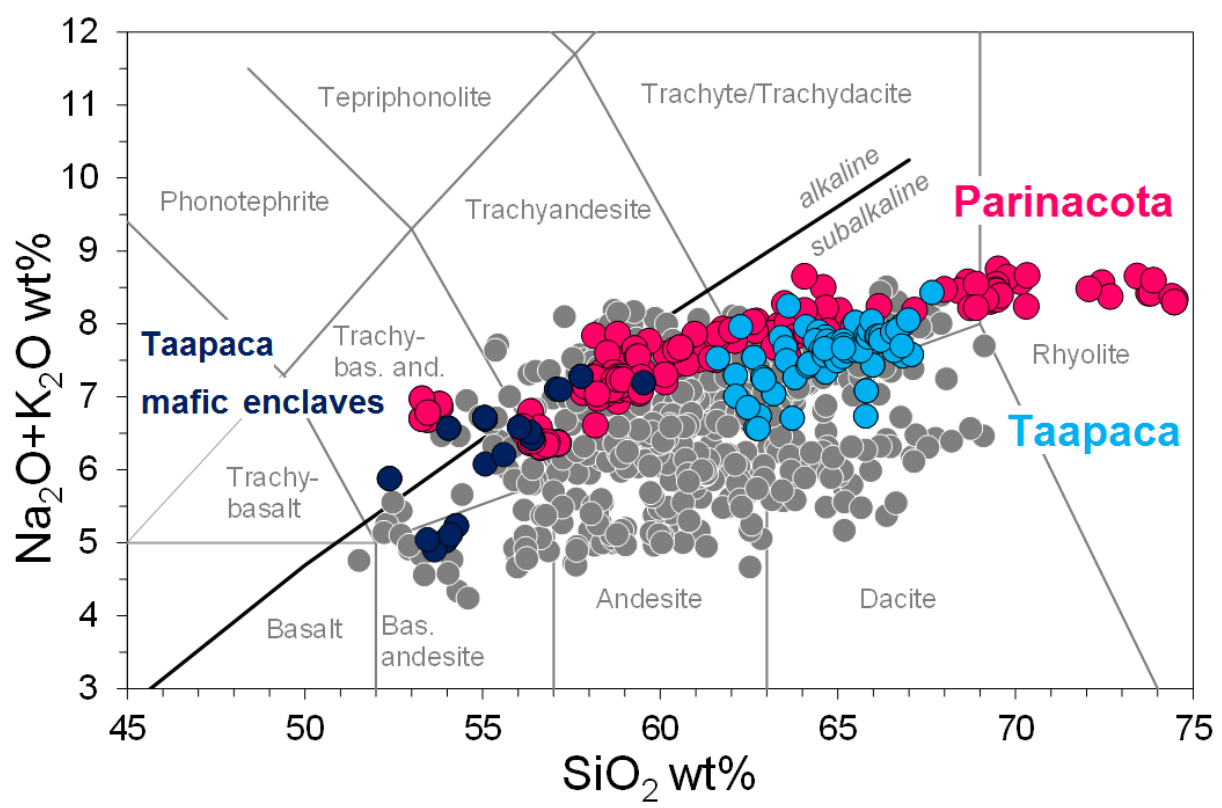

Fig 2. Major element variation in Parinacota and Taapaca compared to Pliocene to Holocene CVZ lavas. Taapaca has a uniform dacite composition for more than 1.5 Ma whereas and varied enclave compositions (dark blue) that mimic the most mafic compositions from flank eruptions at Parinacota. Parinacota produced a large range of lava compositions from basalt to rhyolite in only $60 \mathrm{ka}$.

\subsubsection{Sample and petrography:}

We studied the sanidine megacrysts from dacite samples (Fig. 3) from stage II (1.5-0.5 Ma) to stage IV (0.45 Ma-recent). In the classification by Kohlbach \& Lohnert (1999), these samples belong to stage II and stage III of volcanic evolution. These rocks are volumetrically dominated by grey plagioclase-amphibole porphyritic dacite $\left(62-68 \mathrm{wt} \% \mathrm{SiO}_{2}\right)$ with up to 30 vol\% phenocrysts, 1-6 vol\% mafic enclaves and 1-7 vol\% sanidine megacrysts (Clavero et al. 2004). The matrix of fresh rocks ranges from black, dense and glassy to light grey and friable textures due to incipient degassing. Oxidized samples show transitions from light grey to pink and brownish-red colors due to syneruptive oxidation. For size-based classification, crystals are catagorized as follows; megacrysts: $>15 \mathrm{~mm}$; phenocrysts: $0.3-15 \mathrm{~mm}$, microcrysts: $0.03-$ $0.3 \mathrm{~mm}$ and crystalite: $<0.03 \mathrm{~mm}$. All dacites from Taapaca contain plagioclase (10-20 vol\%), Amphibole (up to 6 vol\%), Fe-Ti oxide (up to 5 vol\%), biotite (up to 3 vol\%), quartz $(<2$ vol\%), apatite $(\sim 1 \mathrm{vol} \%)$, titanite $(<1 \mathrm{vol} \%)$ and other accessory minerals $(<1 \mathrm{vol} \%)$ including zircon and clinopyoxene. Sanidine constitutes $1-7$ vol\% of the dacite, their abundance and average size increase during the course of eruptions from stage I to IV. Plagioclase $\left(\mathrm{Ab}_{45}-\mathrm{Ab}_{80}\right)$ occurs as crystallites, microcrysts and phenocrysts. Common textures in plagioclases include sieve textures with oscillatory zoning and multiple resorption interfaces. Amphibole crystals are euhedral to subhedral, crystalites to phenocrysts in size; 
with some microcrysts showing prominent zoning after resorption. Biotite occurs as fragmented euhedral to subhedral phenocrysts. Oxide and clinopyroxene crystals are generally euhedral to subhedral microcrysts. Quartz phenocrysts are up to $25 \mathrm{~mm}$ in size and, rounded, fractured and strongly resorbed.
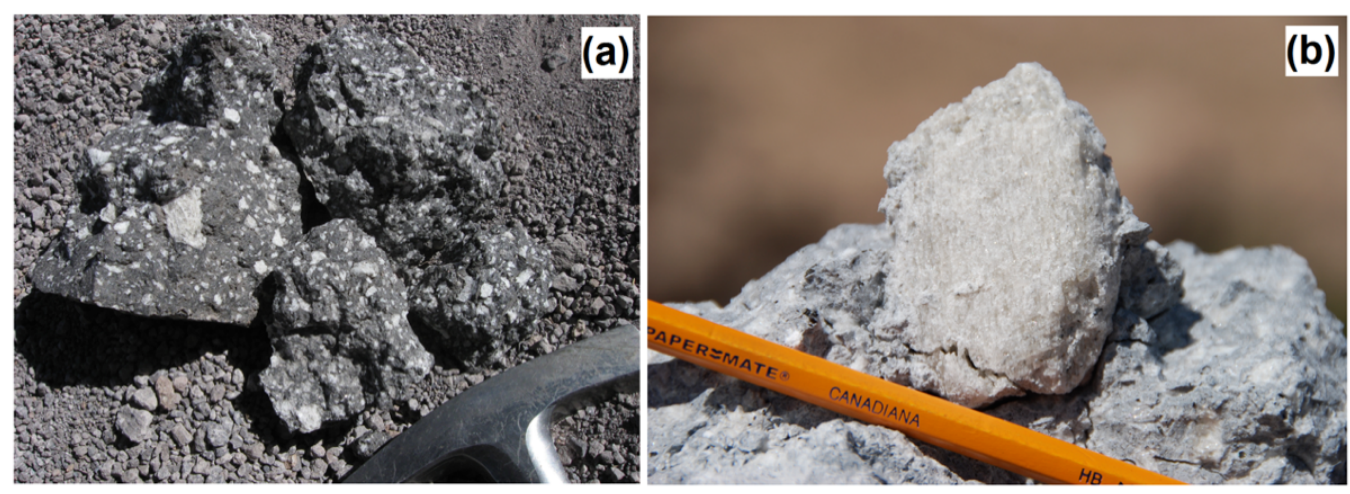

Fig 3. Examples of dacite and sanidine megacryst in hand specimen.

Sanidine megacrysts (Fig. 3b), which are the subject of study, are euhedral, rarely rounded after resorption, range from 15 to $100 \mathrm{~mm}$ in size in the longest dimension. The megacrysts contain large amounts of euhedral to subhedral inclusions of amphibole, plagioclase, titanite, Fe-Ti oxide and sporadically biotite and apatite. Size, shape, composition and zonation patterns (see below) of these megacrysts are indistinguishable from K-spar megacrysts that are frequently observed in granitic rocks (e.g. Vernon 1986; Slaby et al. 2008; Glazner and Boudreau 2011). Granitic K-spar megacrysts have been interpeted either to reflect magmatic crystallization or subsolidus (or close-to-solidus) textural modification (see discussion in Holness et al. 2018). As we will argue below, Taapaca sanidines are megacrystic, magmatic products that formed at relatively high, magmatic temperatures above the eutectic. 


\subsection{Methods}

\subsubsection{Analytical methods:}

The 24 different euhedral sanidine megacrysts from the Taapaca volcanic complex were studied from the intermediate stages of eruptions (stage II \& III). The crystals were impregnated with the silicate-binding agent and then heated in the furnace at $90^{\circ} \mathrm{C}$ for $\sim 12$ hours. This procedure was repeated five times to saturate and harden the crystals. The crystals then were cut at $\sim 400 \mu \mathrm{m}$ from the center perpendicular to the (010) crystallographic plane and perpendicular to the cleavage on this plane. The larger half of the crystal was ground, lapped and polished. Polished surfaces were glued on to a glass slide and the crystals were cut carefully by a low speed saw to obtain a $400 \mu \mathrm{m}$ thick slab remaining on the slide. The top side was again ground, lapped and polished. To avoid contamination during electron microprobe work, the samples were cleaned and baked at $75{ }^{\circ} \mathrm{C}$ prior to carbon coating to ensure electrical conductivity at the surfaces during measurements.

Microprobe analyses were performed at a JEOL JXA-8900R microprobe at GZG, Universität Göttingen. Measurements were done at $15 \mathrm{KV}$ accelerating voltage, $15 \mathrm{nA}$ beam current and 5-15 $\mu \mathrm{m}$ beam size. Counting times for all the elements except $\mathrm{Ba}$ and $\mathrm{Sr}$ were $15 \mathrm{sec}$ on peak and $5 \mathrm{sec}$ on the background. For $\mathrm{Ba}$ and $\mathrm{Sr}$, a maximum of $120 \mathrm{sec}$ on peak and $60 \mathrm{sec}$ on background were used. Calibration standards for feldspar were albite for $\mathrm{Na}$, anorthite for $\mathrm{Si}$, $\mathrm{Ca}$ and $\mathrm{Al}$; sanidine for $\mathrm{K}$; hematite for $\mathrm{Fe}$; celsian for $\mathrm{Ba}$; and $\mathrm{SrTiO}_{3}$ for $\mathrm{Sr}$. EMP measurements were also done on the amphibole inclusions used for thermometry in the sanidine megacryst studied as an application of the model to natural sample. Counting times for all the elements were $15 \mathrm{sec}$ on the peak and $5 \mathrm{sec}$ on the background. Calibration standards were olivine for $\mathrm{Si}$ and $\mathrm{Mg}$, albite for $\mathrm{Na}$, anorthite for $\mathrm{Al}$, sanidine for $\mathrm{K}$, hematite for $\mathrm{F}, \mathrm{TiO}_{2}$ for $\mathrm{Ti}$, Wollastonite for $\mathrm{Ca}, \mathrm{Cr}_{2} \mathrm{O}_{3}$ for $\mathrm{Cr}$, Rhodonite for $\mathrm{Mn}$ and $\mathrm{NiO}$ for $\mathrm{Ni}$. The relative standard deviation for major oxides was below $2 \%$ and the absolute error calculated for minor oxides was between 0.003 and $0.03 \mathrm{wt} \%$.

Accumulated back scattered electron (BSE) images were prepared by superimpositions of ten individual BSE image accumulations acquired in COMPO mode with $20 \mathrm{kV}$ accelerating voltage and $20 \mathrm{nA}$ beam current and a slow scanning beam with acquisition time of $120 \mathrm{sec}$ per accumulation. Mappings have also been carried out in the inclusion-poor regions identified by the COMPO-images. During each mapping, five elements, $\mathrm{Ba}, \mathrm{Ca}, \mathrm{Fe}, \mathrm{Na}$ and $\mathrm{K}$ were measured simultaneous and additionally a BSE- image of the same area was also 
recorded. The mapping sections/areas were between $0.12 \mathrm{~cm} \times 0.5 \mathrm{~cm}$ and $0.5 \mathrm{~cm} \times 0.5 \mathrm{~cm}$, with multiple (up to 3) sections per crystal. A stage scan was used with an accelerating voltage of $20 \mathrm{kV}$, beam current of $40-50 \mathrm{nA}$ and a beam diameter of $10 \mu \mathrm{m}$. The grey-scale values in the BSE images show an apparent linear correlation with the Ba intensities in the Ba-maps (see below) and thus could be used as a proxy for Ba-content. In addition, X-ray line scans for $\mathrm{Sr}, \mathrm{Ca}$ and $\mathrm{Ba}$ were also acquired in COMPO-mode stage scan condition to resolve the compositional transition in selected crystals. 50 accumulations per scan were acquired perpendicular to the core-rim boundary at $10 \mathrm{kV}$ accelerating voltage and $30 \mathrm{nA}$ beam current, with an acquisition time of $2 \mathrm{sec}$ per pixel. The grey-scale values in the accumulated BSE images are linearly correlated with Ba content (see below) and thus are used as a proxy for Ba-content.

Trace-element line profiles were obtained for a selected sample with Laser ablation ICPMS (LA-ICPMS; an Element 2 ICP-MS instrument (Thermo scientific, USA), coupled with a 193 $\mathrm{nm}$ ArF excimer laser ablation system (RESOlution M-50, Australian scientific instrument, Australia)) at GZG, Universität Göttingen using beam diameter of 80-120 $\mu \mathrm{m}$, shooting times upto $1200 \mathrm{sec}$, laser frequency $10 \mathrm{~Hz}$ and dwell time of 20-50 ms. As standard, the certified glass "nbs 610-614" was used. The data from electron microprobe and LA-ICPMS are given in supplementary material 1.

\subsubsection{Thermo-barometry:}

For constraining temperature, we applied thermometric formulations to mineral inclusions in the dacite and in the sanidine megacrysts. Two types of thermometers: given by (1) Blundy and Holland (1994) and (2) Ridolfi and Renzulli (2012) are used. Blundy and Holland (1994) proposed a thermometer based on edenite-tremolite and edenite-richterite equilibria for amphibole coexisting with plagioclase in silica saturated rocks. The thermometer obtains temperature values with uncertainties of $\sim \pm 28^{\circ} \mathrm{C}(1 \sigma)$ and works for rocks equilibrated at temperatures in the range of $400-1000{ }^{\circ} \mathrm{C}$. We used the amphibole and plagioclase compositional data to obtain the temperatures which, for different zones of the megacrysts, lie between 720 and $820^{\circ} \mathrm{C}$, and for the dacites, lie between 680 and $920^{\circ} \mathrm{C}$, but with a bimodal distribution.

The second thermometer (Ridolfi and Renzulli 2012) for amphibole-bearing calc-alkaline and alkaline products of subduction-related systems is based on experimental and natural data to propose empirical thermo-barometric formulations for different compositional components of 
amphibole. We applied the formulation to individual amphibole inclusions and phenocrysts. For the dacites, the obtained temperatures lie between 710 and $950{ }^{\circ} \mathrm{C}$, and for the megacrysts, they lie between 740 and $845^{\circ} \mathrm{C}$, which are $20-30{ }^{\circ} \mathrm{C}$ higher than the amphiboleplagioclase thermometer. For the diffusion modeling, however, we use the temperatures from both the thermometers, compare the results and present the more suitable data set.

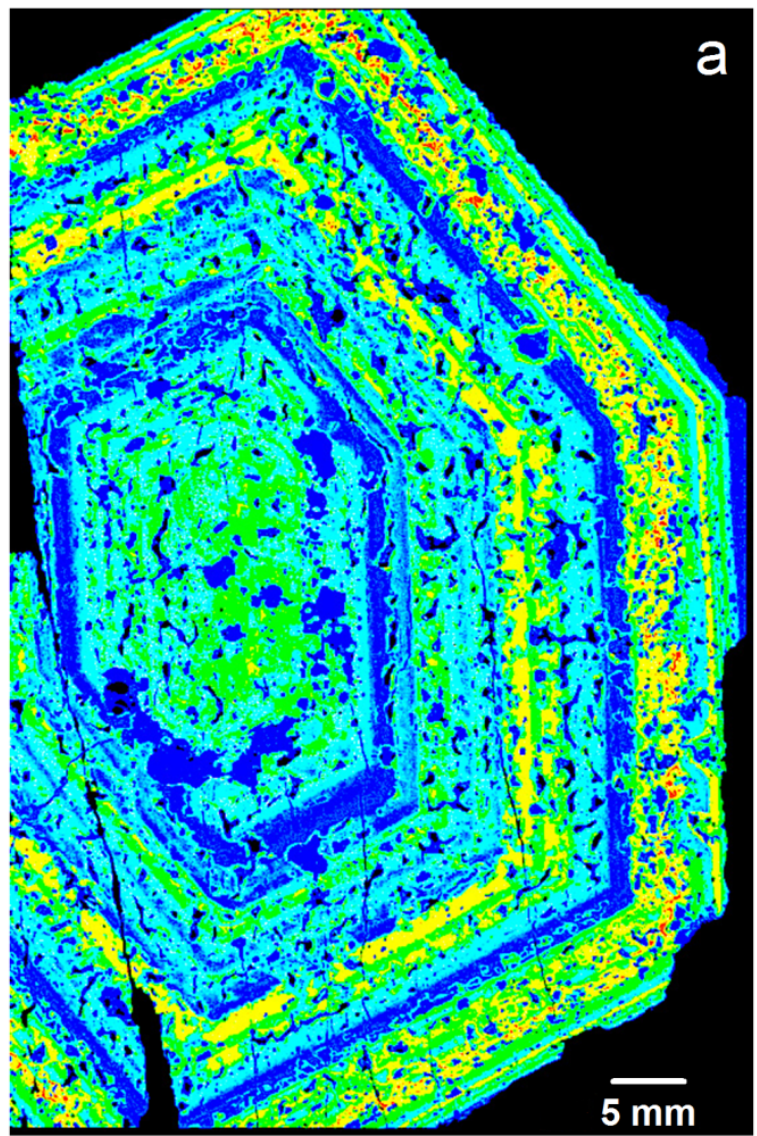

Low Ba
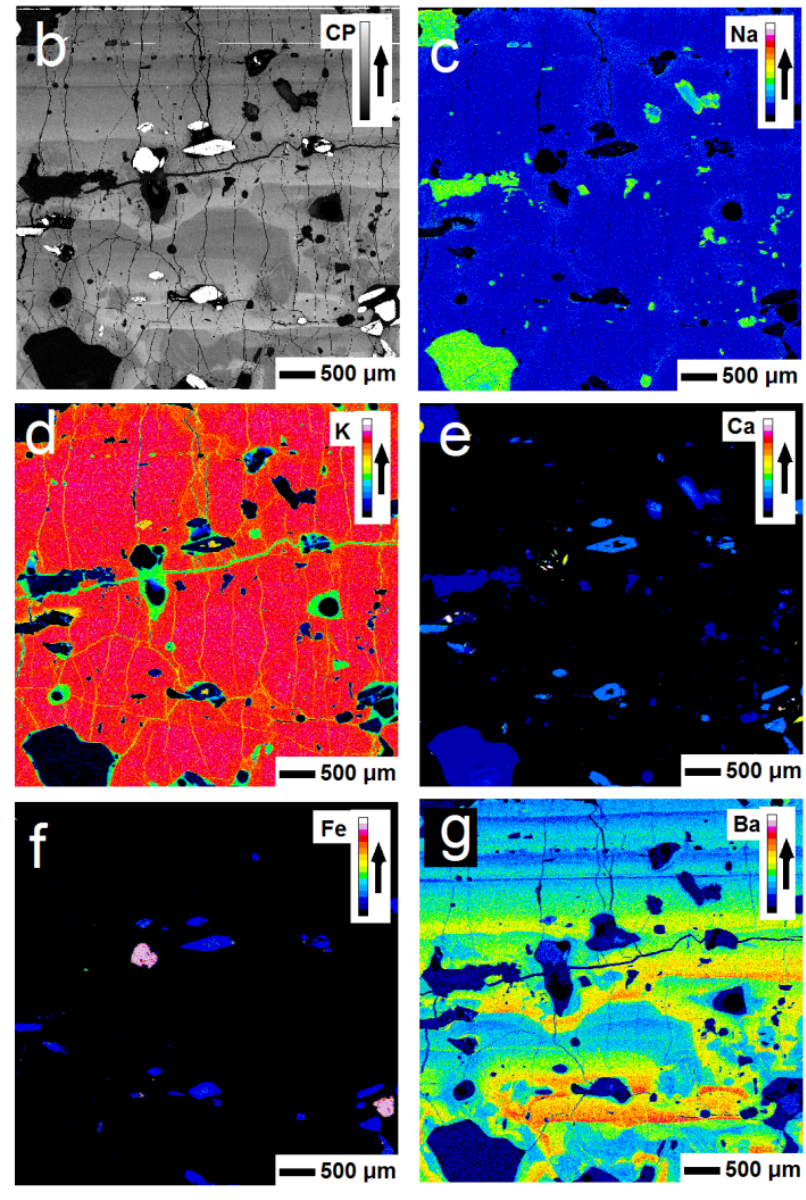

Fig 4. (a) Example of a selected sanidine megacryst (TAP 28/1; Lohnert 1999) showing the typical Ba-zonation pattern (in Ba-intensity map from EMP). (b) Compo image, and (c) Na-, (d) K-, (e) Ca-, (f) Fe- and (g) Baintensity maps of another sample TAP $07 \mathrm{~K} 2$.

Apart from temperature and diffusivity, we constrain the pressure and $\mathrm{fO}_{2}$ with the formulations given by Ridolfi and Renzulli (2012) for amphibole compositions. For pressure, we additionally use two further barometric formulations based on Al in hornblende (Johnson and Rutherford 1989; Mutch et al., 2016). Considering results from all barometers, the estimated pressures lie between 1 and $3 \mathrm{kbar}\left(4-10 \mathrm{~km}\right.$ depth) and oxygen fugacity of $\operatorname{logfO} \mathrm{O}_{2}$ 
between -11 and -13 for the megacrysts. The pressure for the dacite was between 1-7 kbar (bimodal with two ranges 1-3 kbar and 4-7 kbar). The thermo-barometric data are given in supplementary material 2 .
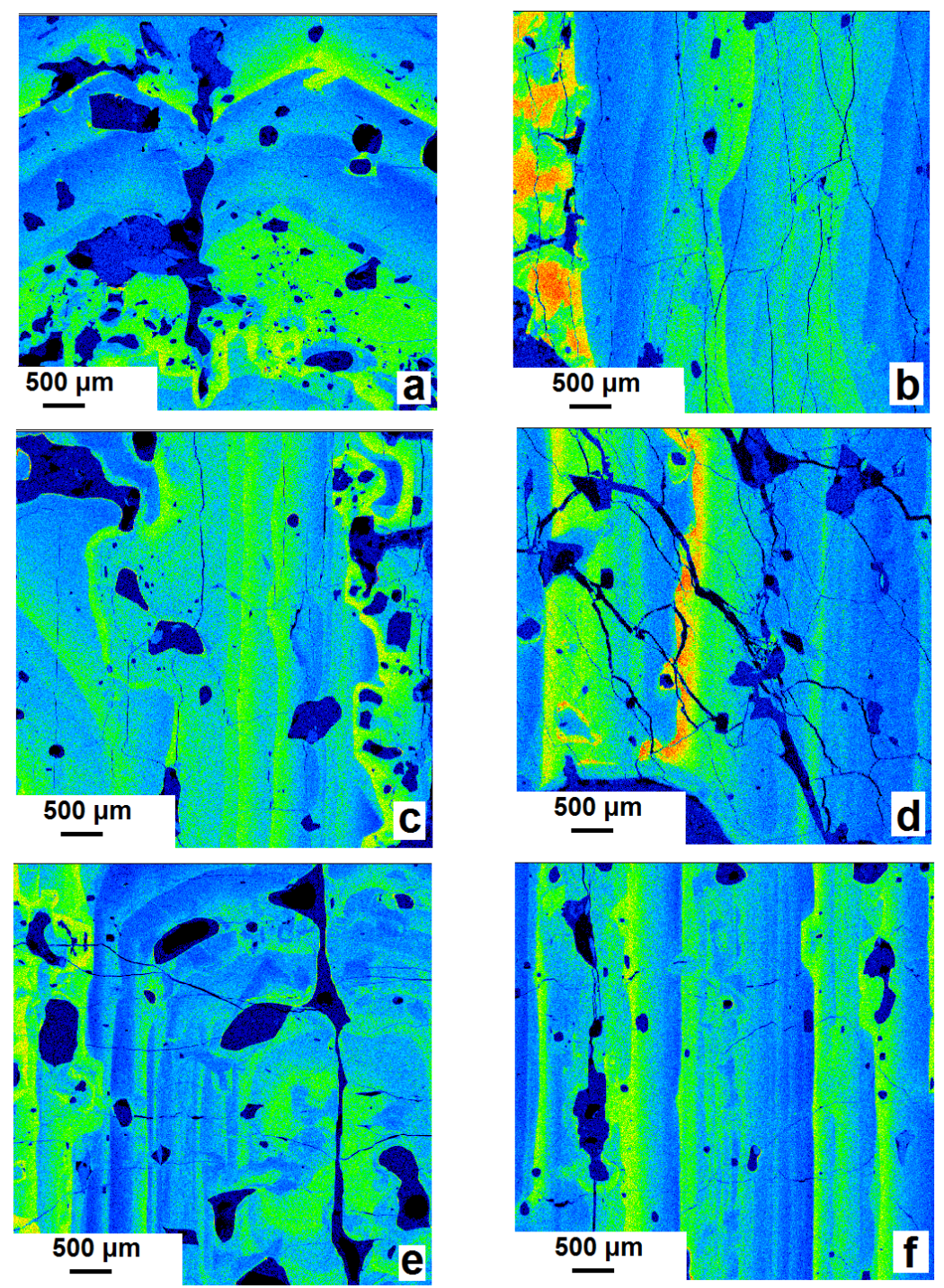

Fig 5. More examples of the Ba-zonation pattern in 6 sanidine megacrysts. (a), (e) and (f) from sample TAP 28; and (b) $18 \mathrm{~K} 1$, (c) $34 \mathrm{~B} 1$ and (d) $11 \mathrm{~K} 1$. Images for TAP 28 crystals are taken from Wegner (2004)

\subsubsection{Rhyolite-MELTS modeling}

In order to further constrain temperatures of storage, we modeled crystallization of the host rhyolite magma reservoir using the Rhyolite-MELTS package (Gualda et al. 2012). As the starting composition we used the estimated composition of the rhyo-dacitic end-member (Blum-Oeste and Wörner 2016) with $\mathrm{SiO}_{2}=68.8 \mathrm{wt} \%, \mathrm{TiO}_{2}=0.5 \mathrm{wt} \%, \mathrm{FeO}=2.7 \mathrm{wt} \%$, $\mathrm{MgO}=0.8 \mathrm{wt} \%, \mathrm{MnO}=0.05 \mathrm{wt} \%, \mathrm{CaO}=2.8 \mathrm{wt} \%, \mathrm{Na}_{2} \mathrm{O}=4.6 \mathrm{wt} \%, \mathrm{~K}_{2} \mathrm{O}=2.7 \mathrm{wt} \%, \mathrm{P}_{2} \mathrm{O}_{5}=0.17$ wt $\%$ and $\mathrm{H}_{2} \mathrm{O}=1-6 \mathrm{wt} \%$. Redox conditions were set at the Ni-NiO buffer (based on 
experimental data, Botcharnikov et al. unpublished). Modeling was conducted at 100-300 $\mathrm{MPa}$, consistent with the barometric results from amphiboles in this study. At these pressures, R-MELTS predicts liquidus temperature of about $950-1000{ }^{\circ} \mathrm{C}$ (for different combinations of pressure and water content), with plagioclase $\left(\mathrm{Ab}_{40}-\mathrm{Ab}_{45}\right)$ as the first liquidus phase followed by oxides and pyroxene at $940-990{ }^{\circ} \mathrm{C}$. Sanidine starts to crystalize at $735-760{ }^{\circ} \mathrm{C}$. The rheological lock-up, where the system transforms into a rigid crystal mush (with crystallinity of 40-50 vol\%, Bachmann and Bergantz 2008) was reached at $750-770{ }^{\circ} \mathrm{C}$. Although Gualda et al. (2012) suggest that R-MELTS is not very suitable for near or sub-solidus phase equilibria (Gualda et al. 2012), the solidus was predicted at $\sim 700{ }^{\circ} \mathrm{C}$. Considering this value and other studies on rhyolitic compositions (e.g. Storm et al. 2014; Rubin et al. 2017 and others), we use $\leq 700{ }^{\circ} \mathrm{C}$ as the solidus for our interpretation.

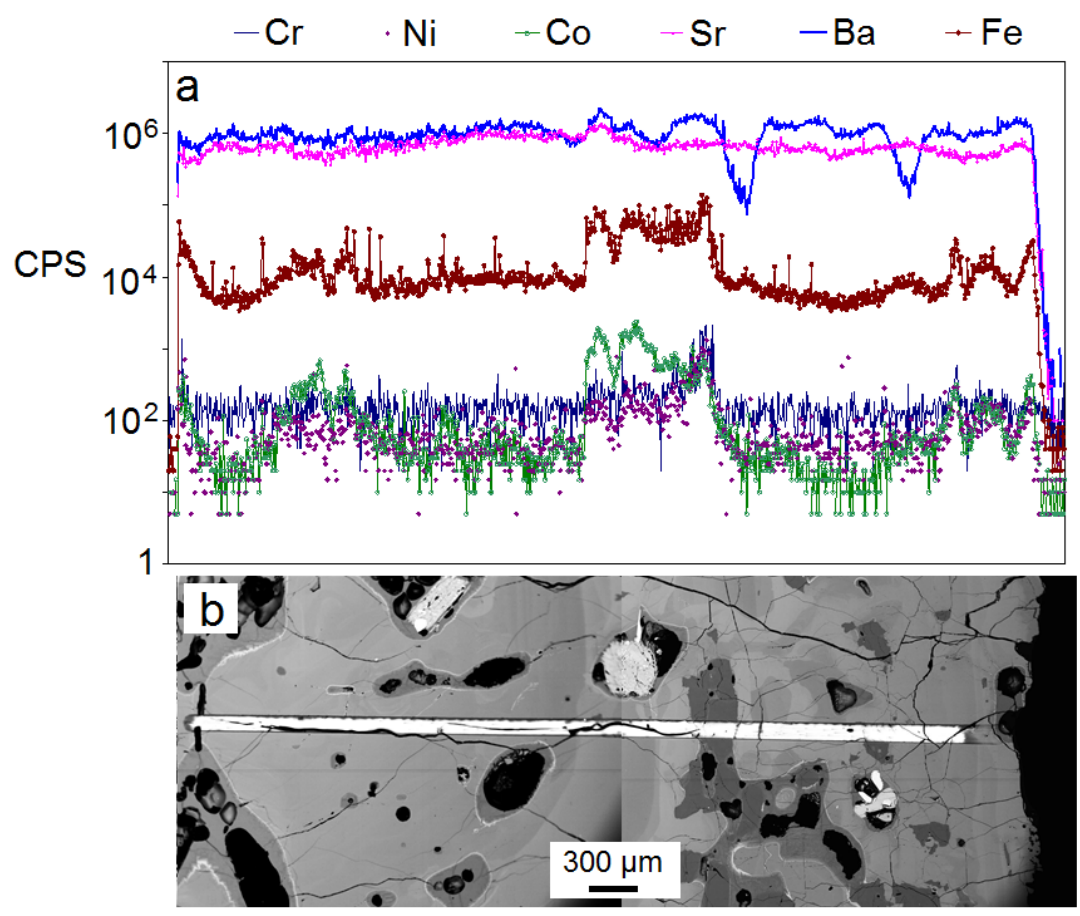

Fig 6. (a) Example of a laser-ICP profile across high- and low Ba growth zones shows no variation in compatible elements in a selected (b) sanidine megacryst (29 K3). 


\subsection{Results and discussion:}

\subsubsection{Patterns and Style of compositional zonation in Taapaca sanidine megacrysts}

Compositions of sanidine megacrysts vary from $\mathrm{Or}_{65}$ to $\mathrm{Or}_{80}$ with An-contents between 0.3 and $1 \%$. Spectacular compositional zonation shows multiple oscillatory growth bands from core to rim (Fig. 4 and 5) primarily in Ba which is often correlated with sporadically observed to be correlated with $\mathrm{Sr}$ and $\mathrm{Ca}$. Our main focus is directed to link $\mathrm{Ba}$ (a) zoning patterns, growth texture, their causes and correlation between single crystals to (b) the time-scales of crystal residence times and growth. Based on these observations, we will develop a model for the temperature-time-composition histories of the megacrysts and their relation to the magmatic regime below Taapaca volcano.

\section{The Ba zonation: texture, cause and correlation}

Fig. 4 to 7 show example images of Ba zonation patterns from different sanidine megacrysts from different eruptive units of Taapaca volcano obtained from compositional mapping by electron microprobe. A full representation of more than 24 sanidine crystals mapped during the course of this study is documented in supplementary form (supplementary material 3). At first sight, the variability of zonation patterns and styles is staggering. However, there are certain "motifs" that can be observed in all Ba-maps: The most prominent structure are resorption growth bands (RG-type) that show a typical saw-tooth pattern with an abrupt increase in $\mathrm{Ba}$ immediately after re-growth following the resorption event and a seemingly exponential decline in $\mathrm{Ba}$ until the next resorption interface (Fig. 7). These repeated resorption and re-growth bands dominate the zonation pattern across all crystals for $80-95 \%$ of the radial distance between core and rim. The larger the compositional difference (i.e. the higher the Ba jump after regrowth) the deeper and more pronounced the resorption interface develops (Fig. 4, 5 and 7). The Ba-content varies between 0.2 and $2.5 \mathrm{wt} \%$ across the resorption and re-growth bands. In some cases, the resorption interface is highly irregular resulting in a patchy aspect after subsequent growth (Fig. 5b). Mineral inclusions (mostly amphibole and plagioclase) are concentrated near the resorption interface at early stages of regrowth. This results in alternating bands with high abundance of small inclusions (Fig. 8).

A second style of zoning is the fine-scale oscillatory (O-type) zonation (Fig. 7) with typical amplitudes of $0.2-0.7 \mathrm{wt} \% \mathrm{BaO}$ and widths of around only $30-150 \mu \mathrm{m}$. In addition to these 
zonations, we observe many glass inclusions which resulted from incipient partial melting of the sanidine just prior to eruption. These glass inclusions are also concentrated in bands parallel to the zonation pattern, indicating that only compositions were affected. In some cases, the melt inclusions show inward crystallization of zoned sanidine along their rims, probably following cooling within a dome after eruption. This melting of sanidine crystals complicates and partly spoils the Ba compositional maps but this effect is likely caused by a final heating and/or decompression event related to the eruption.
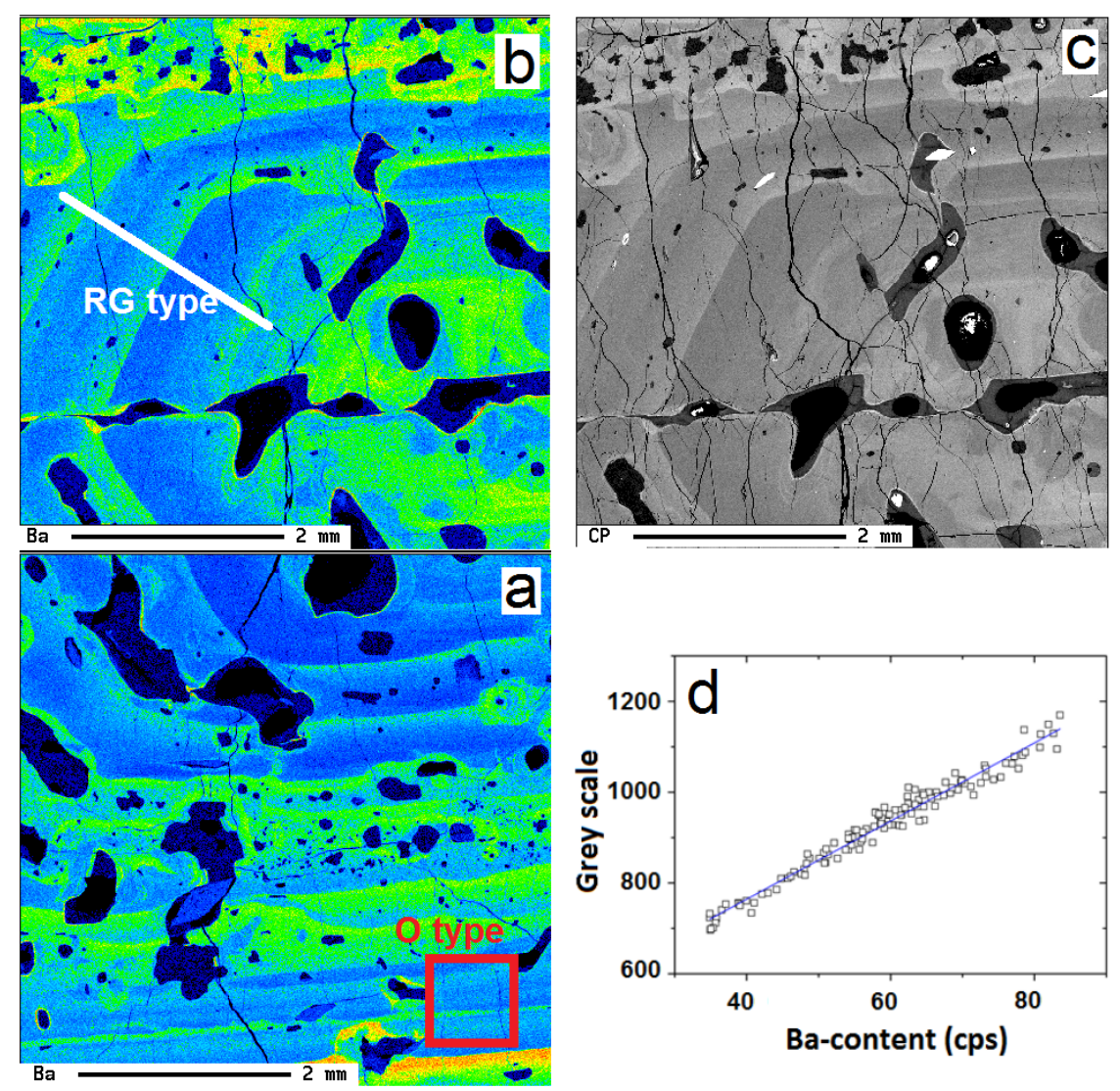

Fig 7. (a) and (b) showing the two distinct set of frequency and amplitude of Ba-zonation pattern. (c) BSE counter-part of (b) for visual comparison (after Wegner 2004). (d) Plot showing the correlation between the grey-scale and Ba-content of a selected sample (07 K2).

To interpret these textures and the origin of the zonations, a few important observations and questions need to be discussed first. 


\section{What is the composition of the host melt from which the sanidine crystals have formed?}

In order to address this question, we invert the measured $\mathrm{Sr}$ and $\mathrm{Ba}$ concentrations in the sanidine by using a range of crystal-melt partitioning coefficients and compared the calculated melt $\mathrm{Ba}-$ and $\mathrm{Sr}$ concentrations to those observed in erupted volcanic products of Taapaca and nearby Parinacota volcano (Parinacota data from Hora et al., 2009 and unpublished data; Taapaca data from Blum-Oeste and Wörner, 2016). Results are shown in Fig 9.

Fig. 9 also shows a simple 4-stage fractional crystallization model (parameters in supplementary material 4) which connects the hybrid magma feeding into the Parinacota magma system with the evolved resident rhyodacite endmember (RD) and further to the differentiated calculated high-Si rhyolite compositions from which sanidine crystals have formed. Note that a few rhyolites domes with $>72.4 \% \mathrm{SiO} 2$ were erupted at Parinacota, which indicates the rare eruption of such magma compositions to the surface. A glassy matrix from one of the rhyodacite domes also falls into this field of evolved compositions. Crystallization of sanidine from such melts has been verified by experiments (Botcharnikov et al, unpublished data) and R-MELTS modeling (this study) at $<760{ }^{\circ} \mathrm{C}$ at $1-3 \mathrm{kbar}$ of pressure.
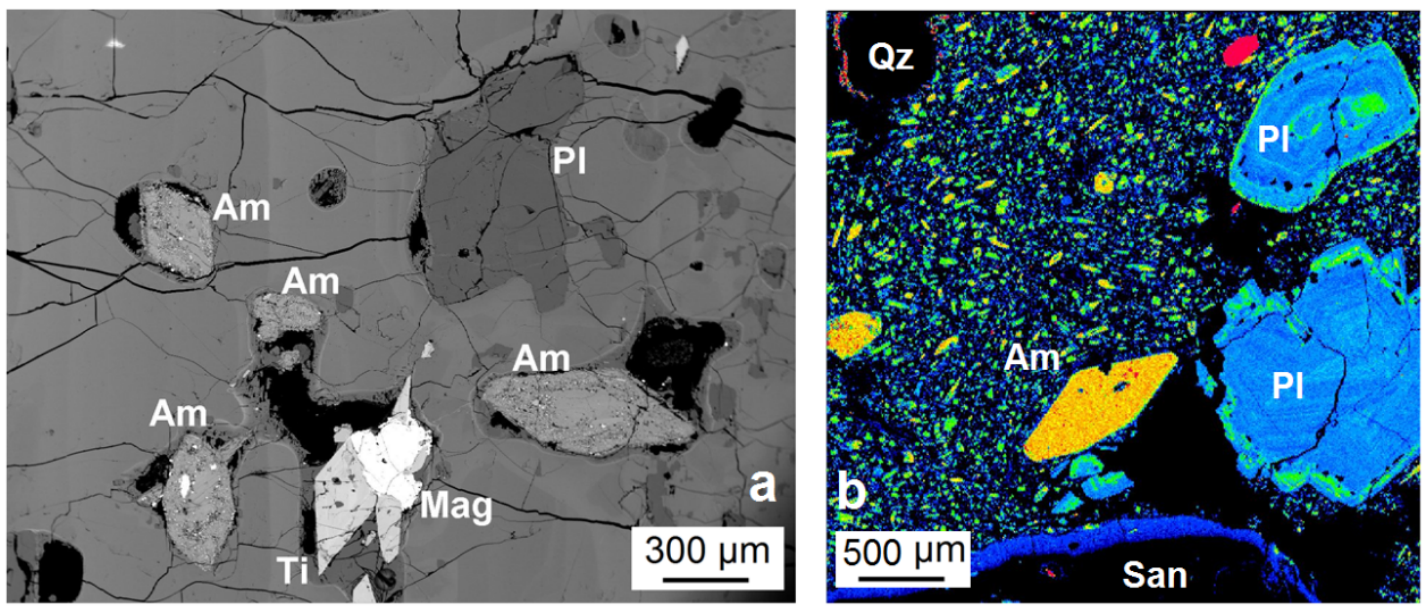

Fig 8. Example of (a) mineral inclusions in a selected sanidine megacryst (07 K1, BSE image) and (b) phenocrysts in a selected dacite sample (TAP 97-11, Ca-intensity map). 


\section{What causes the frequent resorption events recorded in the crystals?}

Dissolution can be caused by one or combination of several possible processes (Ginibre et al. 2007, Shore and Fowler 1996, Pankhurst et al. 2018) e.g. (1) temperature change caused by movement of the crystals to a zone of higher temperature or by a fresh magmatic input or (2) a local mixing due to recharge of a less evolved magma with higher concentrations of barium or (3) decompression caused by magma ascent or by eruption of a part of the magma volume.

The pressure estimates from the barometry (supplementary material 2) lie between 1-3 kbar without significant variation between adjacent zones. Some crystals even have very homogenous and large cores (up to $5 \mathrm{~mm}$ in diameter). the cores of most $(>60 \%)$ of the megacrysts are Ba-poor $(<0.3 \mathrm{wt} \%)$ and yield a relatively low temperature and pressure (from thermo-barometry) than mantle and rim suggesting that they were not formed from a less evolved hotter magma at greater depth. These observations suggest against a continuous decompression that would produce such large number of resorption events throughout the residence history of these megacrysts. Mixing with a fresh batch of less evolved and Ba-rich magma is a plausible option (Clavero 2002 and Lohnert 1999). However, the overall composition except for $\mathrm{Ba}, \mathrm{Sr}$ and $\mathrm{Ca}$ is primarily the same across the zone boundaries (Fig 4, 6). The quantitative analysis (supplementary material 1) suggests intra-crystal Orthoclase content, along with major and trace element concentration, to be consistent for all the megacrysts. Banazsak 2007 and Lohnert 1999 measured the $\delta^{18} \mathrm{O}$ and ${ }^{87} \mathrm{Sr} /{ }^{86} \mathrm{Sr}$ ratio and found them to be consistent at $7.2 \pm 0.2 \%$ and $\sim 0.707$, respectively, throughout individual crystals. Detailed laser-ICPMS-profiling across Ba-jumps in selected crystals resolved no compositional difference in elements that would indicate growth from more or less mafic melts (Cr, Co, Ni, Fe, Fig. 6). These observations suggest against any physical mixing with a fresh less evolved melt prior to dissolution and subsequent growth. However, the dacite, with abundance of mafic enclaves (up to 5-6 vol\%, Zellmer and Clavero 2006), is interpreted to be a hybrid magma that was formed by the mixing and mingling between a rhyodacite and a range of hybrid basaltic andesite magmas (Blum-Oeste and Wörner 2016; Banzsak 2014). These studies suggest there was indeed mixing with a much less evolved hotter melt. However, the intra-crystalline consistency in major element, trace element and isotopic composition suggests that these mixing events were possibly (1) very late stage and (2) localized; late stage enough not to alter the megacryst composition and localized enough not to change the melt composition in other parts of the reservoir. But they would certainly elevate the temperature in different regimes of the reservoir causing dissolution, provided the 
reservoir was divided into several regimes, which is a very plausible option (e.g. Kahl et al. 2013, 2015; Rubin et al. 2016; Jackson et al. 2018). In that case, only the regimes undergoing direct recharges, will be chemically affected (causing chemical mixing between the rhyodacite and basaltic andesite) while other regimes will only experience thermal changes. In the regimes undergoing chemical mixing only, eruption may or may not be triggered as a result. In the reservoirs that are not chemically affected by the recharge, the overall composition would remain the same during the subsequent growth after dissolution (Ginibre et al. 2004, 2007). This is supported by the magnitude of thermal diffusivity (order of $10^{-7} \mathrm{~m}^{2} / \mathrm{s}$; Romine et al. 2012; Hofmeister et al. 2016) which is much faster than chemical diffusivity (e.g. e.g. by at least 8-9 logarithmic order faster than $\mathrm{Ba}$ or $\mathrm{Sr}$ at $800{ }^{\circ} \mathrm{C}$; Zhang et al. 2010) making effects of thermal changes comparatively much faster and spatially extensive. Similar results would also be obtained, if the crystals were transported within the magma system to a zone of higher temperature. However, the high crystallinity (at least 31-37 vol\%) would make convection difficult within the dacite. Thus, the RG-type zonation was more likely the result of thermal effects of distant mafic recharges and subsequent mixing. If such thermal pulses result in partial resorption of crystals, then slow diffusing elements compatible in sanidine $(\mathrm{Ba}, \mathrm{Sr}$ and Ca) may become enriched at the crystal melt boundary layer. 


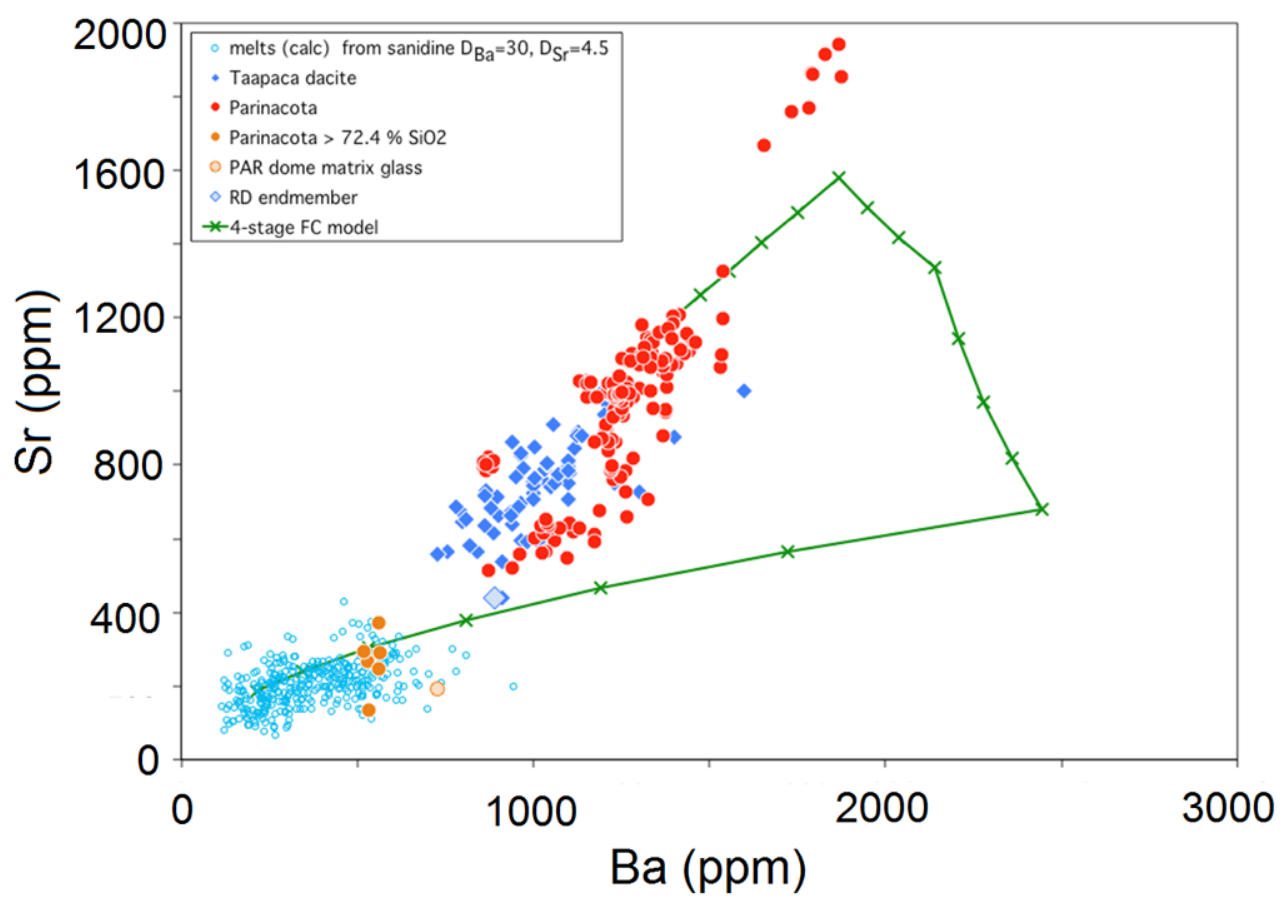

Fig 9. Comparison between the calculated melt Ba- and $\mathrm{Sr}$ concentrations to those observed in erupted volcanic products of Taapaca and nearby Parinacota volcano (Parinacota data from Hora et al. 2009 and unpublished data; Taapaca data from Blum-Oeste and Wörner 2016). The green line is a simple 4-stage fractional crystallization model which connects the hybrid magma feeding into the Parinacota magma system with the evolved resident rhyodacite endmember (RD) and to the high-Si rhyolite compositions from which sanidine has crystallized.

The absence of any compositional variation across the resorption and zonation interfaces other than for $\mathrm{Ba}, \mathrm{Ca}$, and $\mathrm{Sr}$ (Fig. 6) indicates that the resorption boundaries are result of only thermal effects, i.e. formed by melting the sanidine within its rhyodacite host rather than mafic recharge and chemical mixing between two melts of different composition and different temperature. Amphibole inclusions in sanidine are exclusively Mg-amphibole whereas the host dacite shows a bimodal composition with $\mathrm{Mg}$-amphibole and $\mathrm{Mg}$-hastingsite (which represents the mafic recharge). Upon application of thermometry, the bimodal composition of the amphibole also yields bimodal temperatures i.e. $680-800{ }^{\circ} \mathrm{C}$ corresponding to the silicic end member (and similar to the temperatures from the megacrysts' inclusions) and 820-920 ${ }^{\circ} \mathrm{C}$ for the mafic endmember, respectively (Fig. 10). This suggests that the sanidines grew in the rhyodacite which later mixed with the mafic component to form the dacite which brought the megacrysts to the surface.

The robust conclusion, that changing temperature, not composition, has caused the Ba-Sr-Cazonation patterns in Taapaca sanidine megacrysts forms the background for answering the following questions: 

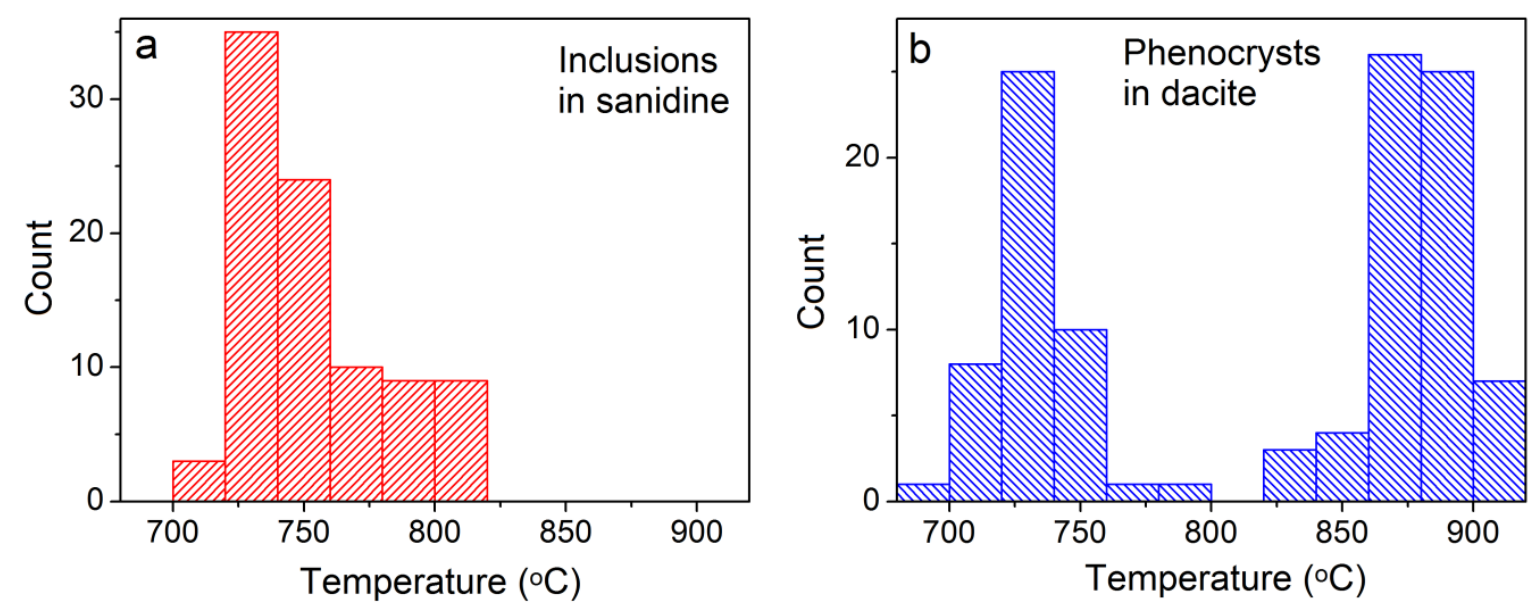

Fig 10. Temperature data from amphibole-plagioclase thermometry (Blundy and Holland 1994) from (a) inclusions in sanidine megacrysts and (b) phenocrysts in the hybrid dacite. Bimodality is evident in case of dacite.

\section{What is the cause for the megacrystic growth?}

The reason for the unusually large size (up to $12 \mathrm{~cm}$ ) of many crystals still remains uncertain and has been debated for K-feldspar of similar size and zonation patterns in megacrystic granites e.g. by Higgins (1999) who proposed a process of textural coarsening. Such a process is indeed a reasonable explanation since we have shown that the magma temperature is repeatedly cycled close to the K-feldspar liquidus for a long period. Small crystals have a higher surface energy per unit volume than larger crystals and thus, to minimize the energy in the system, crystals smaller than a particular size ("critical size"; Higgins 1999) dissolve and contribute to the growth of the lager crystals. This coarsening process is sensitive to the overall thermal evolution and thus, could explain the differences in crystal sizes between samples with similar residence times. Since, composition and zonation patterns are so strikingly similar to many examples described from megacrystic granites, we argue that these similar occurrences in plutonic environments also formed from coarsening due to temperature cycling. 


\section{What causes the gradual decrease in Ba concentration between dissolution events?}

The continuous, quasi exponential decrease in $\mathrm{Ba}$ after a resorption boundary can be explained by the development of a chemical boundary layer that becomes depleted in $\mathrm{Ba}$, which is a compatible element in sanidine (Ginibre et al. 2002). The thermometric results and R-melts modeling suggest that majority of the sanidine growth took place at temperatures $<760-770{ }^{\circ} \mathrm{C}$. During growth at such temperatures, the chemical diffusivity of elements like $\mathrm{Ba}$ and $\mathrm{Sr}$ (Zhang et al. 2010) becomes too low (Eq 1) to replenish the melt composition near the crystal-melt interface leading to the observed boundary layer depletion. This process continues until the next dissolution event and sharp increase in concentration occurs due to growth from an enriched melt after dissolution, forming the observed saw-tooth pattern (Fig 11). We tested the correlation between the degree of dissolution and the following Baenrichment by plotting (1) the ratio of (a) distance covered by curved resorption boundary between two points to (b) the actual displacement between the same points, against (2) the relative jump in Ba-content (Fig. 12). The ratios of distance to displacement along the resorption surfaces evidently correlate positively with the relative degree of the associated Bajumps suggesting that a higher degree of dissolution yields a more Ba-enriched-melt near the resorbed crystal, from which regrowth starts after the dissolution event. 

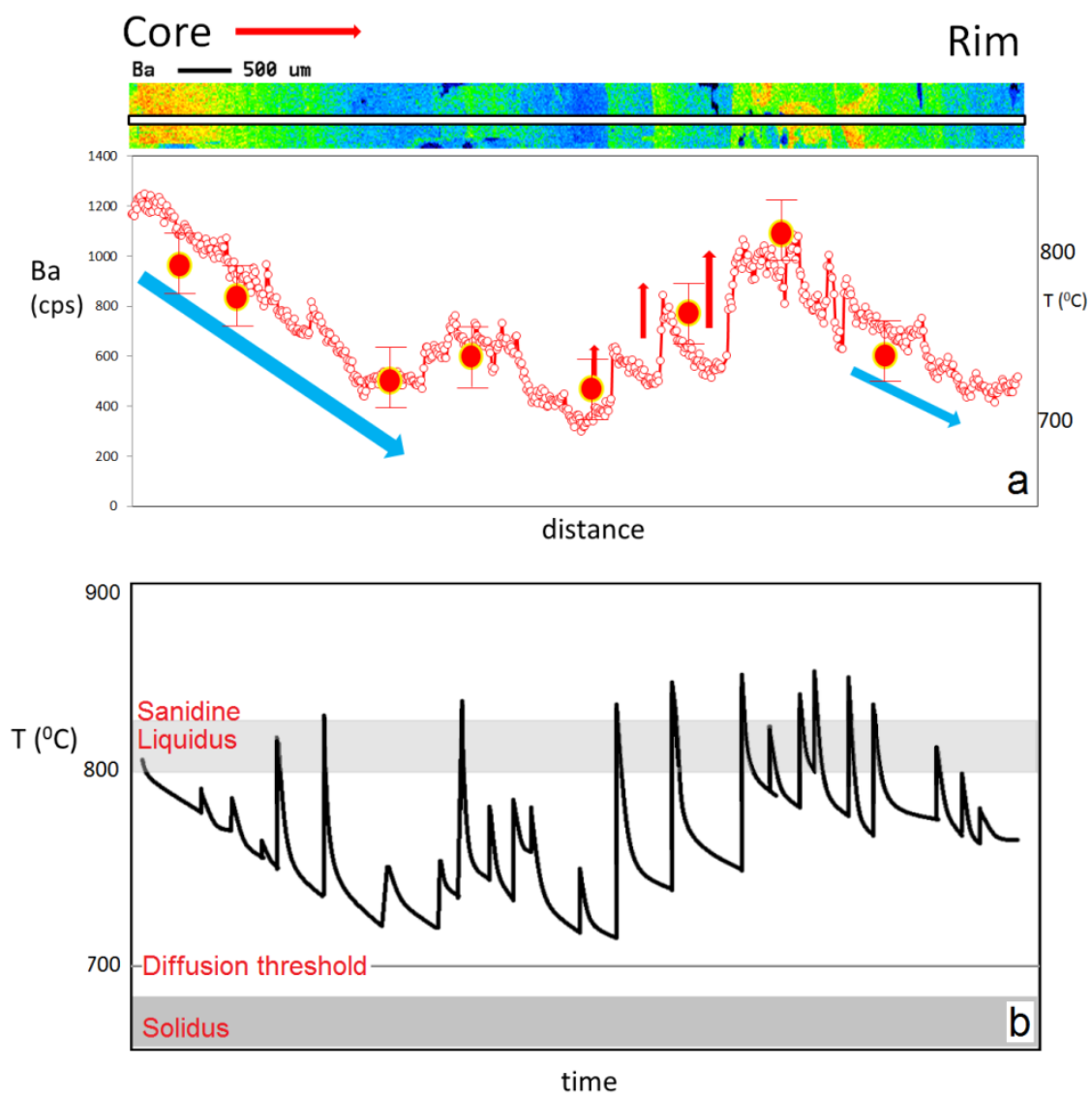

Fig 11. (a) Ba-content from core to rim of a selected crystal showing the saw tooth pattern observed in every megacryst. The red circles are thermometric data superimposed as per the location of the Amphibole inclusion relative to the zonation pattern. The blue and red arrows show over-all cooling and major heating events as interpreted from Ba-zonation. (b) Schematic Temperature vs time plot made using temperature as a proxy for Ba-content [based on (a)].

\section{What is the cause for the fine-scale oscillatory zonation?}

This kind of zonation (30-150 $\mu \mathrm{m}$ width, Fig. 7) is observed only in the mantle and, at higher frequencies (smaller wavelengths), in the outer rims of the crystals. Oscillatory zonation is associated with only small Ba-jumps (from $0.2-0.3 \mathrm{wt} \%$ to a maximum $0.7 \mathrm{wt} \%$ ). These finescale oscillatory zones closely trace the crystal shapes and probably reflect incremental diffusion-controlled growth (Haase et al. 1980, Pearce and Kolisnik 1990, Singer et al. 1995). This type of growth implies steady-state cooling, low degrees of undercooling, and a stable diffusive boundary layer. Growth may have been associated with minor dissolution events as the zone boundaries, being typically euhedral, often have slightly rounded corners and sporadically low amplitude undulating resorption surfaces. Ginibre et al. (2002, 2007) and Shore and Fowler (1996) have summarized some of the existing models that are used to 
explain such zonation, but since their formation does not reflect, and does not allow for estimates of, diffusion and residence times of the crystals at large, we will not consider this type of zonation further.

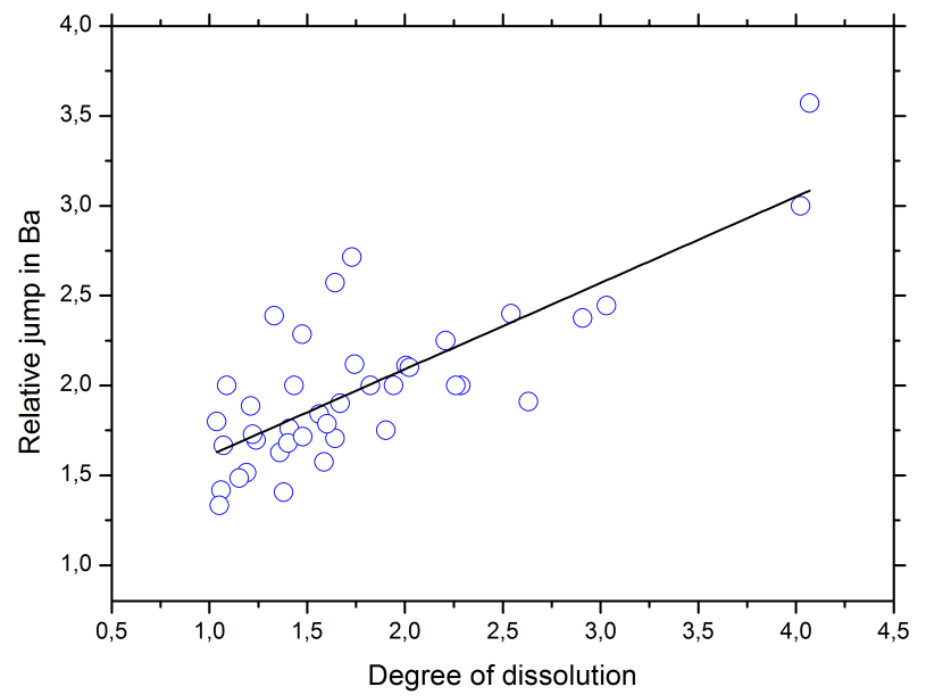

Fig 12. Plot showing positive correlation between the degree of dissolution and relative jump in $\mathrm{Ba}$ across the same dissolution interface. The degree of dissolution is the ratio of (a) distance covered by curved resorption boundary between two points to (b) the actual displacement between same two points.

\section{How can we constrain the thermal history of the megacrysts?}

If, as argued above, the most of the Ba zonation is formed by only thermal variations, then the zonation patterns, and, in particular, the size of Ba-concentration jumps at resorption interfaces, should be a proxy for temperature variations. To test this hypothesis, we correlated the temperatures obtained from amphibole-plagioclase thermometry based on inclusions from within individual growth bands (i.e. between major resorption interfaces) to the Ba-content in profiles from core to rim (Fig 11). The temperature variation correlates relatively well with the Ba-content during growth from core to rim, and thus we speculate that even minor Bavariations reflect changes in temperature. Thus, in Fig. 11b, we show schematically a temperature vs. time history during crystal growth. Since there is no growth during periods of dissolution, we cannot constrain the temperature at the time of dissolution or how long the dissolution period was. Based on previous models (e.g. Cooper and Kent 2014; Rubin et al. 2017; Ginibre et al. 2004) dissolution is thought to be short events of rapid heating above the liquidus followed by slow cooling and longer periods of growth (Fig 11b). 


\section{How to extract crystal residence times from diffusion modeling?}

All zone boundaries are associated with resorption interfaces followed by high-Ba growth. This suggests that the initial compositional profile across the boundary must have been a sharp step profile that was later smoothened by diffusion. This satisfies one of the basic criteria of applying diffusion modeling, i.e. the initial profile before the onset of diffusion has to be a known step profile. This makes these zone-boundaries ideal candidates for diffusion modeling.

Apart from $\mathrm{Ba},<50 \%$ of the megacrysts also show a variation of $\mathrm{Ca}$ across a few zone boundaries ( $<30 \%$ of the total boundaries) that positively correlates with $\mathrm{Ba}$ (supplementary material 1). Even fewer crystals $(<20 \%)$ also show a variation in $\mathrm{Sr}$ across $<10 \%$ of the total diffusion boundaries. The lack of variation in $\mathrm{Sr}$ and $\mathrm{Ca}$ in other samples (and boundaries) could be a result of low $\mathrm{Ca}$ - and $\mathrm{Sr}$-contents (i.e. the variation is within the analytical errors of $\mathrm{X}$-ray scans). Another possible reason could be the significantly ( 100 to 1000 times) higher diffusivity of $\mathrm{Ca}$ and $\mathrm{Sr}$ compared to $\mathrm{Ba}$ in the sanidine or feldspar in general (Cherniak 2010) which, for durations as long as several thousands of years, would erase the initial contrast in Sr-content, while the initial distribution of $\mathrm{Ba}$ would not be totally homogenized. However, due to very high scatter in the x-ray count rates ( $>35 \%$ relative standard deviation) and lack of experimental constraints on Ca-diffusivity in sanidine, the few profiles that do show zonation in $\mathrm{Ca}$ and $\mathrm{Sr}$ could not be modeled, and only Ba-profiles are modeled to obtain diffusion times. 


\subsubsection{Ba-diffusion modeling}

Zellmer and Clavero (2006) previously applied Sr-diffusion speedometry to a sanidine sample (erupted $14.1 \pm 1.4 \mathrm{ka}$ ) from Taapaca volcano. However, the temperature they used $\left(\sim 875^{\circ} \mathrm{C}\right)$ was more than $100{ }^{\circ} \mathrm{C}$ higher than the average storage temperature estimated from our new thermometric calculations. The reason is that we consider the different magma components: Mg-hornblende growing from a low-T rhyolite that is the host of the sanidines and a high-T magma recharge as indicated by Mg-hastingsites in the hybrid dacite and the mafic inclusions. Sanidine growth is limited to temperatures below $760-770^{\circ} \mathrm{C}$ and sanidine resorption and diffusion occurred between $720^{\circ} \mathrm{C}$ and $820^{\circ} \mathrm{C}$. Thus, their results under-estimate diffusion time-scales by a factor of at least $\sim 100$, and therefore, a new and more robust temporal constraints on the crystal residence history are required. However, before applying diffusion modeling to these boundaries, the required parameters must be constrained.

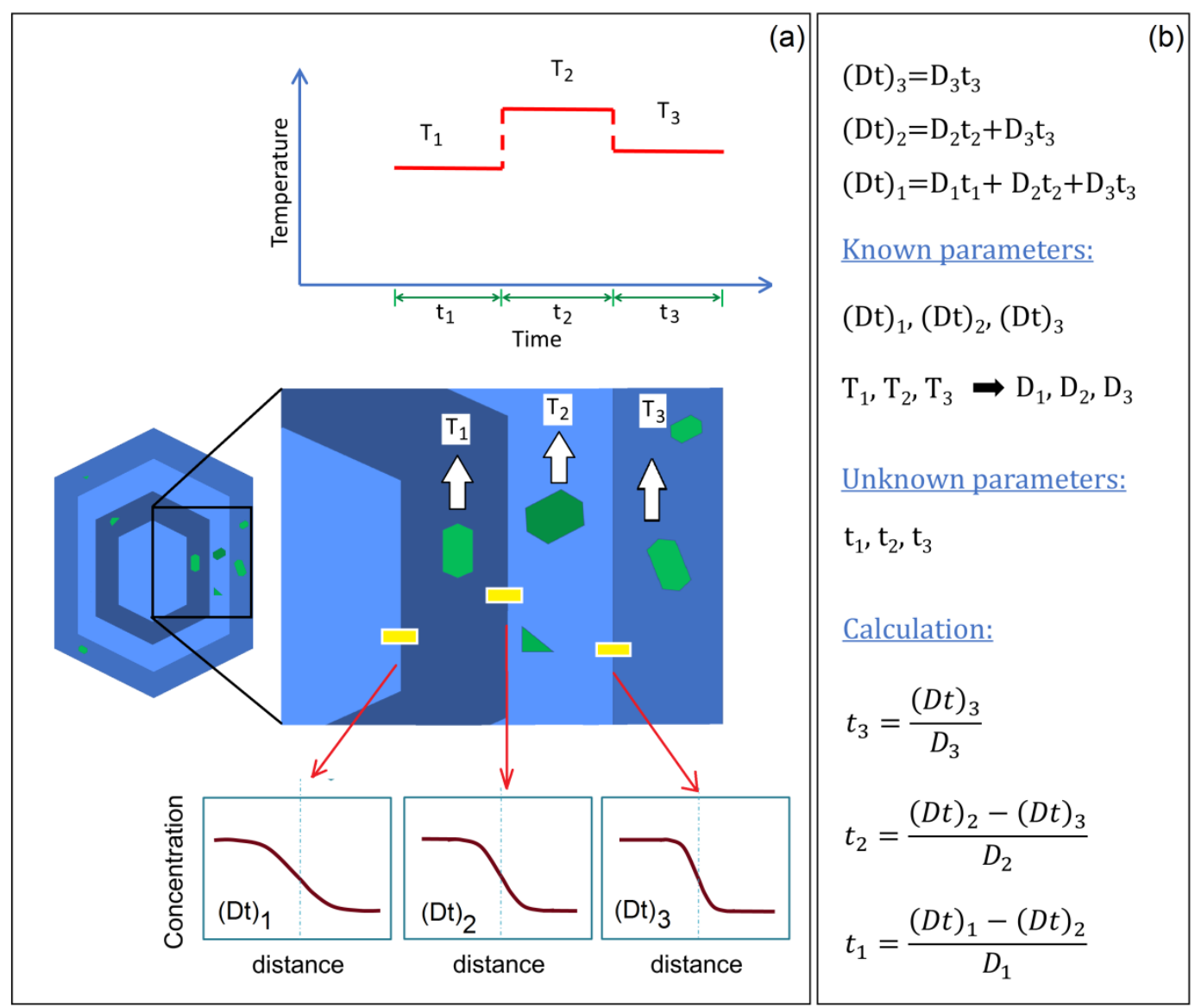

Fig 13. Schematic diagram showing (a) the basics and (b) calculation steps of non-isothermal diffusion modeling used to constrain Ba-diffusion times. 


\section{Temperature:}

Temperatures obtained from different growth zones vary significantly (by up to $80^{\circ} \mathrm{C}$ ) within a single crystal irrespective of the thermometer applied. This suggests a significantly nonisothermal growth, which cannot be constrained by the usual isothermal diffusion modeling and hence, calls for a model which can take the intra-crystal temperature variations into account. Therefore, we use a "non-isothermal diffusion modeling" (see below) which models each zone boundary individually using the temperature obtained from the inclusions hosted in the following zone.

However, the R-melts modeling predicts sanidine-in temperatures at $735-760{ }^{\circ} \mathrm{C}$, while the thermometric calculations suggest temperatures up to $820^{\circ} \mathrm{C}$. This suggests that some of the mineral inclusions might have actually formed and recorded the temperatures during dissolution rather than growth. This makes these temperatures (which are higher than sanidine-in) not applicable to the immediately preceding boundary that hosts the corresponding inclusion. These temperatures are, however, very much applicable to all the older boundaries that formed before as those older boundaries (in the crystal interior) would still diffuse at these higher temperatures while the rims would be melting. Therefore, we set an upper limit of $760{ }^{\circ} \mathrm{C}$ for the temperature and when the temperature is $<760{ }^{\circ} \mathrm{C}$, we apply the temperature to all the boundaries that come before, but when the temperature is $>760{ }^{\circ} \mathrm{C}$, we apply the temperature to all but the immediately preceding boundary.

It is also observed that the temperature values for different inclusions within a single growth zone are always similar to within $\pm 20^{\circ} \mathrm{C}$. In these cases, where we have multiple temperatures within a single zone, we use 0.95 times the highest temperature as the effective temperature as suggested by Chakraborty and Ganguly (1991), who show that for diffusion processes, there is a simple relationship between the peak temperature $\left(\mathrm{T}_{\mathrm{Pk}}\right)$ attained in a variety of nonisothermal histories and the characteristic or effective temperature $\mathrm{T}_{\mathrm{Ch}}: \mathrm{T}_{\mathrm{Ch}}=\sim 0.95 \mathrm{~T}_{\mathrm{Pk}}$ in Kelvin. The diffusion times based on modeling isothermal diffusion at $\mathrm{T}_{\mathrm{Ch}}$ should be a good approximation of the actual diffusion time involving non-isothermal variation (Costa et al. 2008). 


\section{Diffusion coefficients:}

Diffusion coefficients are calculated using the Arrhenius equation between the diffusion coefficient, diffusivity parameters (activation energy and pre-exponential factor) and temperature as follows

$$
D=D_{0} e^{\frac{-E_{A}}{R T}}
$$

Where $\mathrm{D}$ is diffusion coefficient $\left(\mathrm{m}^{2} / \mathrm{sec}\right), \mathrm{E}_{\mathrm{A}}(\mathrm{kJ} / \mathrm{mol})$ is the activation energy, $\mathrm{R}[8.3145$ $\mathrm{J} /(\mathrm{mol} . \mathrm{K})]$ is the universal gas constant, $\mathrm{D}_{0}\left(\mathrm{~m}^{2} / \mathrm{sec}\right)$ is the pre-exponential factor and corresponds to the value of $\mathrm{D}\left(\mathrm{m}^{2} / \mathrm{sec}\right)$ at infinite temperature and $\mathrm{T}$ is the temperature in Kelvin.

We use diffusivity data for Ba from Cherniak (2002) who experimentally determined the diffusivity data for $\mathrm{Ba}$ in natural sanidine under dry 1 atm conditions. No compositional dependence of $\mathrm{Ba}$ diffusion was reported and no significant diffusion anisotropy was observed for normal to (001) relative to normal to (010) directions. Activation energy of $455 \pm 20 \mathrm{~kJ} / \mathrm{mol}$ and pre-exponential factor of $2.9 \times 10^{-1} \mathrm{~m}^{2} / \mathrm{sec}$, as given by Cherniak (2002) for the direction normal to (001), are used in this study to calculate diffusion coefficient at a particular temperature. Although the diffusion experiments by Cherniak (2002) were conducted at the temperature range from $775{ }^{\circ} \mathrm{C}$ to $1124{ }^{\circ} \mathrm{C}$, we extrapolate the Arrhenius relationship (Eq 1) to temperatures below $775{ }^{\circ} \mathrm{C}$ to obtain the diffusion coefficients for the entire range of temperatures i.e. between 720 and $820^{\circ} \mathrm{C}$.

\section{Pressure:}

A dependence of $\mathrm{Ba}$ diffusion on pressure and $\mathrm{fO}_{2}$ has not been detected (Cherniak 2002, 2010) and thus, these values are not essential in our diffusion modeling.

\section{Non-isothermal diffusion modeling:}

The "Non-isothermal incremental diffusion step (NIDIS) model" used to overcome the intracrystal temperature variations was suggested by Petrone et al. (2016), and was modified by Rout et al. (2019) who proposed an alternative simpler algorithm that significantly reduces the errors in diffusion time estimates while remaining mathematically fully consistent with the original NIDIS algorithm. The model calculations start at the rim of a crystal and proceed chronologically backwards towards the core. Each of the calculation steps uses two 
consecutive diffusion boundaries to estimate the diffusion time. The calculation steps (based on Rout et al. 2019) are described below.

Calculation steps: Different temperatures obtained from thermometry on the amphibole and plagioclase inclusions give corresponding individual diffusion coefficients. Each zone boundary is thus modeled for a different temperature. A least square curve fitting (using MATLAB and ORIGIN) of the diffusion profiles is done using the analytical solution for diffusion in semi-infinite system (Crank 1975) i.e.

$$
C(x, t)=\frac{\left(C_{\text {high }}+C_{\text {low }}\right)}{2}-\frac{\left(C_{\text {high }}-C_{\text {low }}\right)}{2} \times \operatorname{erf}\left(\frac{\left(x-x_{0}\right)}{\sqrt{4 D t}}\right)
$$

where $\mathrm{C}(\mathrm{x}, \mathrm{t})$ is the $\mathrm{Ba}$ concentration at position $\mathrm{x}$ after time $\mathrm{t}(\mathrm{sec}) . \mathrm{C}_{\text {low }}$ and $\mathrm{c}_{\text {high }}$ are the initial $\mathrm{Ba}$ concentrations (observed as the plateaus on both sides of the gradient), $\mathrm{D}$ is the temperature-dependent diffusion coefficient $\left(\mathrm{m}^{2} / \mathrm{sec}\right)$ and $\mathrm{x}_{0}(\mathrm{~m})$ is the position of the diffusive interface. The curve fitting of a profile gives the corresponding Dt values.

The Dt value of a diffusion profile that has undergone different temperatures over time $t$ is given as (Crank 1975, Wilson 1970)

$$
D t=\int_{0}^{t} D(T) \times d t
$$

Thus, if the thermal history consists of several smaller isothermal steps e.g. for temperature of $T_{1}$ for time $t_{1}, T_{2}$ for $t_{2}$ and so on up to $T_{n}$ for $t_{n}$, then,

$$
D t=D_{1} t_{1}+D_{2} t_{2}+. .+D_{n} t_{n}=\sum_{n=1}^{n} D_{n} t_{n}
$$

Where $D_{1}, D_{2}, . . D_{n}$ are the diffusion coefficients at $T_{1}, T_{2}, . . T_{n}$, respectively. Eq 4 means that the overall Dt value of a profile (obtained from curve fitting) will be the summation of individual Dt values of all the subsequent boundaries and the very boundary itself. However, note that the individual Dt value and diffusion time of a particular diffusion boundary that was formed by a dissolution and re-growth event reflects only the period of diffusion until the formation of the next resorption boundary. Thus, in Eq 4, if Dt belongs to the first boundary that was formed i.e. (Dt) boundary 1 , which is the overall Dt value of boundary 1, then $(\mathrm{Dt})_{\text {boundary }}$

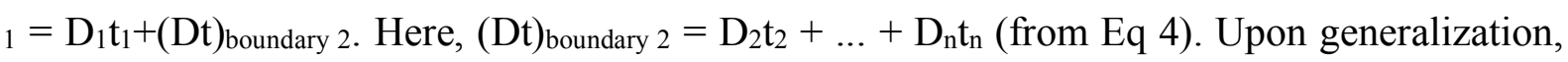
the overall Dt value of nth boundary (starting from core) turns out as: (Dt) boundary $n=$ $D_{n} t_{n}+(D t)_{\text {boundary } n+1}$. Thus, $t_{n}$, i.e. the time between the formation of $n^{\text {th }}$ and $n+1^{\text {th }}$ boundary can be estimated as 


$$
t_{n}=\frac{(D t)_{\text {boundary } n}-(D t)_{\text {boundary } n+1}}{D_{n}}
$$

Where $D_{n}$ is the diffusion coefficient calculated for the temperature obtained specifically for the $\mathrm{n}^{\text {th }}$ zone (the zone between $\mathrm{n}^{\text {th }}$ and $\mathrm{n}+1^{\text {th }}$ boundaries). Thus, the difference in the overall $\mathrm{Dt}$ values of two adjacent zone boundaries is divided by the diffusion coefficient appropriate specifically for the zone " $n$ " in between. This way, the diffusion time reflects the time between the formation of the two successive boundaries. Please note that here and onwards, the "diffusion time of a profile or a boundary" will mean the specific duration of diffusion undergone by that boundary only until the next boundary forms. Fig 13 graphically explains the above steps of diffusion modeling using an example a simple crystal with 3 zone boundaries. Fig 14 shows an example of actual non-isothermal diffusion modeling of a natural sanidine crystal based on Fig 13.
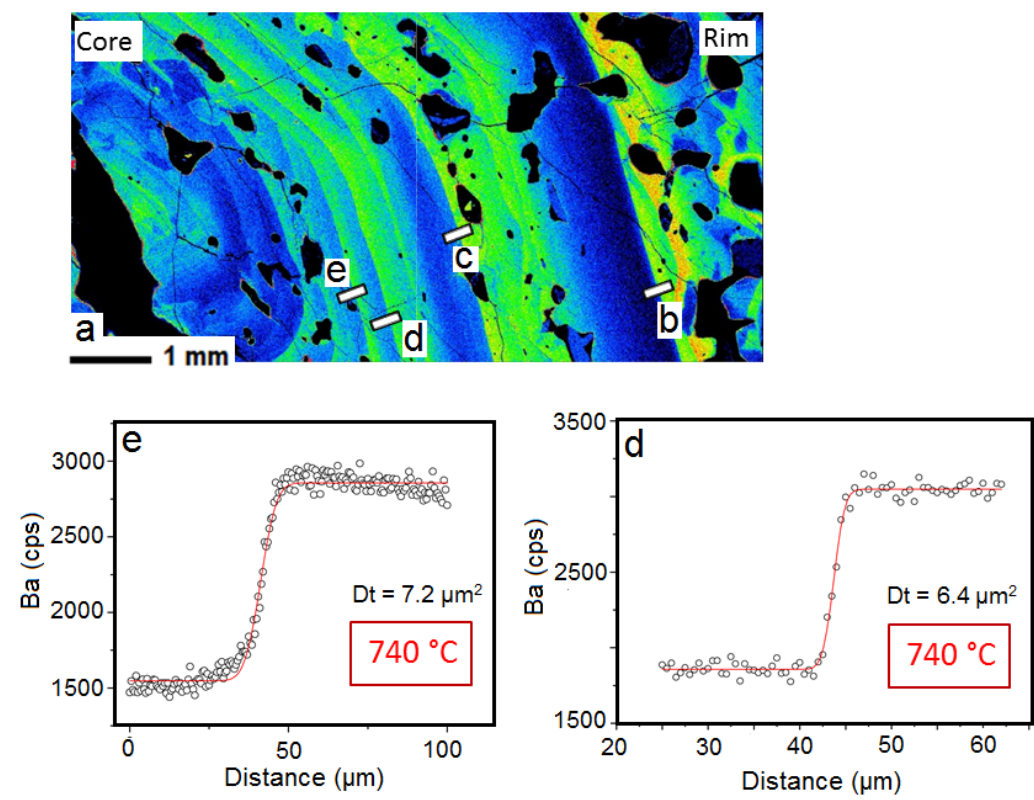
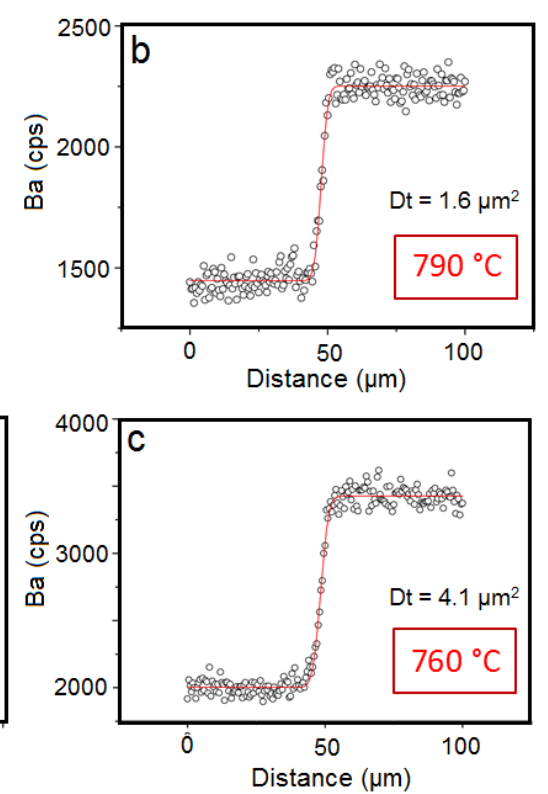

Fig 14. Example of Ba-diffusion modeling. Ba-profiles and model curves (red) across zone bounadries (b), (c), (d) and (e) from core to rim in sanidine megacryst (a). As expected, the diffusion profiles become thinner from core to rim as cores would have longer diffusion times.

Using these steps, the diffusion times for individual profiles are calculated using the temperature values from the two thermometers. We use Ba-diffusion profiles obtained by $\mathrm{x}$ ray line analysis. For a few crystals, we also use grey scale profiles for the analysis as a proxy for Ba (Fig 7d). The summation of the diffusion times from all boundaries gives the total diffusion time, which is a close estimate of total crystal residence time. The only duration not 
accounted in the total diffusion time is the duration of growth of the core before the formation of the first zone boundary. Due to lower temperature (by 20-30 ${ }^{\circ} \mathrm{C}$ ), the use of thermometer by Blundy and Holland (1994) returns 3 to 5 times longer diffusion times compared to using Ridolfi and Renzulli (2012) temperatures. For one dacite studied here, we can estimate the pre-eruptive crystal residence time of $159 \pm 27 \mathrm{ky}$ using the available absolute (U-Th) mineral isochron age of $171 \pm 26 \mathrm{ky}$ and eruption age (Ar-Ar) of $12 \pm 8 \mathrm{ky}$ (Kiebala 2008). We compared the calculated total diffusion time with this crystal residence time and as it turns out, the diffusion time using the thermometer by Holland and Blundy (1994), which yields tens to hundreds of ky, agrees with the crystal residence time based on U/Th dating. Thus, we use that set of time-scales (presented in Table 1 and supplementary material 5) for our interpretations. The other reason for choosing the thermometer by Holland and Blundy (1994) over the one by Ridolfi and Renzulli (2012) is that the slightly lower range of temperature (by 20-30 ${ }^{\circ} \mathrm{C}$ ) ensures constraints on the maximum temporal scales.

In the following sub-section, we present the results for $\mathrm{Ba}$ diffusion modeling on major successive resorption interfaces from core to rim for 24 samples of sanidine megacrysts from Taapaca volcano. A compilation of all results of diffusion modeling is given in Table 1 . The number of analyzed boundaries per crystal varies between 2 and 6 . Some boundaries, that do not have compositional plateaus or mineral inclusions in the following growth zone, are avoided and excluded from the calculation. The low-amplitude oscillatory boundaries are generally devoid of mineral inclusions and thus, are mostly not analyzed for diffusion. 
Table 1. Results from diffusion modeling. Durations from individual zones are in supplementary material 5.

\begin{tabular}{|c|c|c|c|c|c|c|c|}
\hline \multicolumn{2}{|c|}{ Evolution stage } & \multirow[b]{2}{*}{ Sample } & \multirow{2}{*}{$\begin{array}{c}\text { Total number of } \\
\text { zone boundaries } \\
\text { analyzed }\end{array}$} & \multirow{2}{*}{\multicolumn{2}{|c|}{$\begin{array}{c}\text { Total } \\
\text { diffusion time } \\
(\mathrm{ky})\end{array}$}} & \multirow{2}{*}{$\begin{array}{l}\text { Pre-eruptive } \\
\text { speeding up } \\
\text { time } \\
\text { (ky) }\end{array}$} & \multirow{2}{*}{$\begin{array}{l}\text { Last recharge } \\
\text { before } \\
\text { eruption } \\
(\mathrm{ky})\end{array}$} \\
\hline $\begin{array}{c}\text { Kohlbach \& } \\
\text { Lohnert (1999) }\end{array}$ & $\begin{array}{c}\text { Clavero et al. } \\
\text { (2004) }\end{array}$ & & & & & & \\
\hline \multirow{14}{*}{ Stage II } & \multirow{4}{*}{ Stage II } & $18 \mathrm{~B} 3$ & 3 & 117.2 & \pm 95 & $6.6 \pm 7$ & - \\
\hline & & $18 \mathrm{~B} 3 \mathrm{a}$ & 4 & 197.6 & \pm 137 & $8.7 \pm 9$ & - \\
\hline & & $18 \mathrm{~K} 1$ & 3 & 408.1 & \pm 408 & - & - \\
\hline & & $18 \mathrm{~B} 1$ & 3 & 27.6 & \pm 30 & $2.8 \pm 3$ & $1.2 \pm 1$ \\
\hline & \multirow{20}{*}{ Stage IV } & $11 \mathrm{~K} 1$ & 3 & 379.6 & \pm 387 & $10.4 \pm 10$ & - \\
\hline & & $07 \mathrm{~K} 2$ & 3 & 229.6 & \pm 211 & - & - \\
\hline & & $07 \mathrm{~K} 2 \mathrm{a}$ & 4 & 126.8 & \pm 88 & - & $1.4 \pm 1$ \\
\hline & & $07 \mathrm{~K} 1$ & 3 & 227.8 & \pm 153 & - & - \\
\hline & & $30 \mathrm{~B} 1$ & 4 & 28.3 & \pm 18 & $5.5 \pm 6$ & - \\
\hline & & $30 \mathrm{~B} 2$ & 3 & 104.9 & \pm 112 & $3.4 \pm 3$ & $1.2 \pm 1$ \\
\hline & & $30 \mathrm{~B} 2 \mathrm{a}$ & 3 & 9.1 & \pm 7 & $6.1 \pm 6$ & $4.6 \pm 4$ \\
\hline & & $30 \mathrm{~K} 3$ & 3 & 498.6 & \pm 524 & $5.4 \pm 5$ & - \\
\hline & & $30 \mathrm{~K} 4$ & 4 & 120.7 & \pm 85 & - & $1.4 \pm 1$ \\
\hline & & $30 \mathrm{~K} 4 \mathrm{a}$ & 6 & 64.6 & \pm 54 & $7.6 \pm 8$ & $0.4 \pm 0.5$ \\
\hline \multirow{4}{*}{$\begin{array}{c}\text { Transition } \\
\text { stage }\end{array}$} & & $35 \mathrm{~K} 1$ & 3 & 74.1 & \pm 86 & $2.3 \pm 2$ & $1.2 \pm 1$ \\
\hline & & $34 \mathrm{~K} 2$ & 4 & 46.3 & \pm 43 & $3.0 \pm 3$ & $1.0 \pm 1$ \\
\hline & & $34 \mathrm{~B} 1$ & 2 & 72.0 & \pm 85 & - & $0.9 \pm 1$ \\
\hline & & $28 \mathrm{~B} 2$ & 6 & 77.1 & \pm 63 & $7.9 \pm 8$ & $3.3 \pm 3$ \\
\hline \multirow{6}{*}{ Stage III } & & $29 \mathrm{~K} 3$ & 2 & 48.7 & \pm 55 & - & $1.6 \pm 1.5$ \\
\hline & & $29 \mathrm{~K} 1$ & 3 & 36.7 & \pm 37 & $6.4 \pm 7$ & $2.0 \pm 2$ \\
\hline & & $29 \mathrm{~B} 1$ & 3 & 41.1 & \pm 38 & $10.8 \pm 11$ & $2.1 \pm 2$ \\
\hline & & $29 \mathrm{~B} 1 \mathrm{a}$ & 5 & 395.6 & \pm 326 & $15.3 \pm 15$ & - \\
\hline & & $01 \mathrm{~B} 1$ & 2 & 35.0 & \pm 37 & - & $1.2 \pm 1$ \\
\hline & & $01 \mathrm{~B} 2$ & 2 & 28.9 & \pm 31 & - & $0.9 \pm 1$ \\
\hline
\end{tabular}




\section{What are the time-scales obtained from diffusion modeling?}

The total residence times obtained from the diffusion modeling for different crystals varies significantly within the samples of a particular dome and between samples from domes of different stratigraphic stages of Taapaca's eruptive history (from 1.5 Ma to Recent). For stage II, the diffusion times are between 27 and $408 \mathrm{ky}$ while for stage IV, the duration is between 9 and $499 \mathrm{ky}$. Based on our new diffusion times we extract apparent average growth rates of $\sim 5 \times 10^{-13} \mathrm{~cm} / \mathrm{s}$ (with the range being from $\sim 10^{-13}$ to $\sim 10^{-12} \mathrm{~cm} / \mathrm{s}$ ) at $720-820{ }^{\circ} \mathrm{C}$. The apparent growth rate must be smaller than the actual rate of growth as crystals suffered frequent events of dissolution that interrupted periods of growth. The calculated total diffusion times, however, is unaffected by intermittent times of dissolution. We also did not find any correlation between crystal size and residence time. This supports the earlier interpretation that although the general history might be same for all the crystals, different crystals must have grown at different points of time and at different parts of the reservoir undergoing different durations and degrees of dissolution.

The estimated residence times from diffusion modeling naturally excludes the time between the start of sanidine growth until the formation of the first analysed zone boundary (the coremantle boundary in most cases). However, the duration until the first analysed boundary can be constrained using the apparent growth rate extracted from rest of the crystal, which approximates this duration at 5-30 ky depending on the size of the core. Since our thin sections were always prepared to cut through the crystal cores and no bias is expected from sectioning, this should be a reasonable estimate. In any case, because the total residence times are already in the order of tens to hundreds of thousands of years, the addition of such relatively short durations will not change the order of magnitude of the total diffusion time significantly and thus, will not affect our interpretations.

The total residence times of sanidine crystals from a particular eruptive stage of the volcano (Table 1) varies significantly. Using the classification by Kohlbach \& Lohnert (1999) suggests that "younger" crystals (29-77 ky) erupted in more recent eruptions and therefore the crystal residence times decreased over time as the system became more active. Crystals that were stored over longer times (up to $499 \mathrm{ky}$ ) were erupted earlier in the volcano's history. Only sample 29 Bla from stage 3 is an exception (with at least $396 \mathrm{ky}$ of storage) suggesting that some relatively older crystals may have been mobilized from older resident magmas at a later (younger) stage as well. However, as per the classification by Clavero et al. 2004, only 4 out of 24 crystals fall within the stage II (i.e. the older eruption phase) of their classification 
and hence such a comparison is not possible. In any case, crystals were formed and stored for thousands of years in the magma reservoir during all stages of volcanic evolution of Taapaca volcano.

\subsubsection{Storage history prior to eruption}

Diffusion times for individual resorption boundaries, i.e. the duration between consecutive heating events, varies from 1 to $50 \mathrm{ky}$. This time interval decreases towards the rim of the crystals: diffusion times for the outer-most 2-4 boundaries (close to the rim) of most crystals ranges from 1 to $10 \mathrm{ky}$ which is significantly shorter than the frequency of resorption and diffusion intervals for the inner boundaries (>30-50 ky) i.e. boundaries close to the core. This increasing rate of heating and recharge events suggests that the resident rhyodacite magma reservoir that contained the sanidine megacrysts became more frequently disturbed by recharge until the eventual mobilization of the system about $\sim 3-11$ ky prior to eruption. This time-scale of $\sim 3-11 \mathrm{ky}$ is obtained by adding the individual diffusion times of the outer boundaries that give shorter diffusion times (1-10 ky). The outer most of the major resorption boundaries give even shorter diffusion times of only 0.4-3 ky. This implies that the last major heating (and recharge) event that possibly caused the eruption occurred only hundreds to a few thousands of years before eruption. It is to be noted that at the final stage of growth, some sanidine crystals formed a thin overgrowth of $\sim 1$ to $1.5 \mathrm{~mm}$ with relatively more narrow growth and resorption bands (Fig. 5, 7 and 11). Diffusion modeling in this growth zone was impossible do to the lack of temperature constraints. However, we speculate, that this shift in zonation pattern towards even higher frequency of compositional variations should be directly linked to the eruption process, possibly including ascent and dome emplacement.

Crystal residence and magma storage times estimated for sanidine-bearing Taapaca rhyodacites are long compared to most basaltic or some silicic magma systems (e.g. Bourdon et al. 1994; Morgan and Blake 2006; Druitt et al. 2012; Kahl et al. 2015; Albert et al. 2016; Allan et al. 2017; Cooper 2019). However, Passarelli and Brodsky (2012), in their study based on eruption database from 34 arc volcanoes worldwide, suggest that it is not unusual for rhyolitic or dacitic volcanoes to have repose time between eruptions (corresponding to the frequency of "successful" recharge events) of thousands of years. 


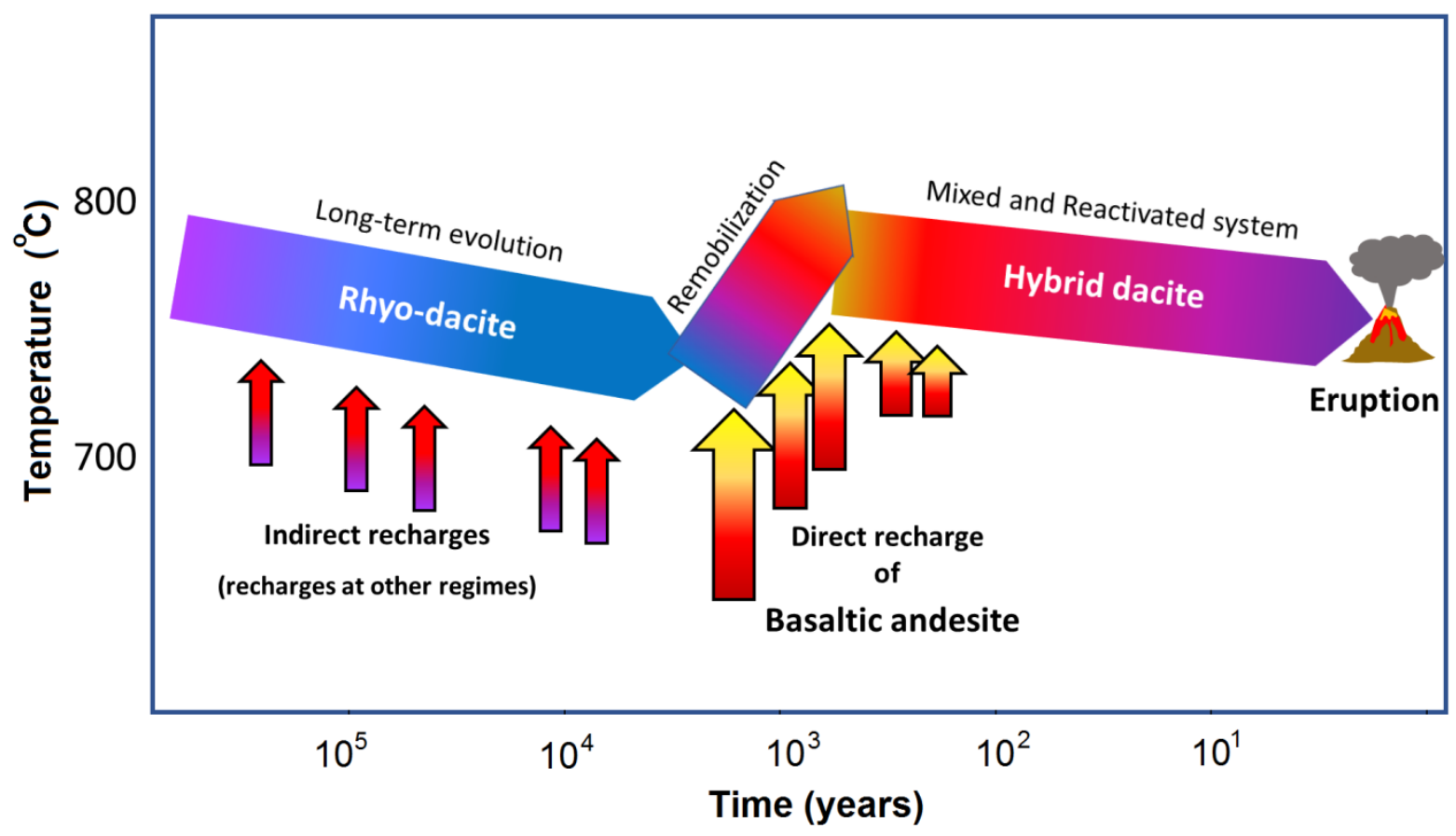

Fig 15. Schematic diagram showing the pre-eruptive history of Taapaca reservoir (based on Ba-zonation pattern and diffusion times. This cycle was repeated multiple times within the $1.5 \mathrm{Ma}$ long eruption history leading to eruption of different segments of the reservoir.

\section{Cold vs. hot storage}

Two models have been proposed to constrain the magma storage temperature and time-scales. Barboni et al. (2016) and Kaiser et al. (2017) suggest (1) a long (tens to hundreds of thousands of years) storage of crystals in a high-temperature melt-rich reservoir ("warm storage") whereas Cooper and Kent (2014) and Reid (2008) provided evidence for (2) subsolidus low temperature $\left(<700{ }^{\circ} \mathrm{C}\right)$ storage ("cold storage") for thousands of years, probably as a crystal-rich mush (Bachmann and Bergantz 2008). Regarding duration of storage, our calculations indicate thousands of years of crystal storage (regardless of the thermometer used) which agrees with both the models and with a number of previous studies done on silicic volcanoes (e.g. Cooper and Kent, 2014; Rubin et al. 2017; Morgan and Blake 2006 to name a few). For storage conditions at lower temperatures $\left(\sim 650-700{ }^{\circ} \mathrm{C}\right)$ below the diffusion threshold for a particular element (e.g. $\mathrm{Ba}$ as in our study) diffusion essentially stops. In that case, residence times extracted from diffusion modeling will be substantially shorter than the actual crystal "ages" as recorded in U-Th isotope ages (e.g. Cooper and Kent 2014 and Rubin et al. 2017). We estimate the diffusion threshold for $\mathrm{Ba}$ (for details see supplementary material 6) to be less than $\sim 700{ }^{\circ} \mathrm{C}$. Since the amphibole-plagioclase thermometry (Holland and Blundy 1994) and amphibole thermometry (Ridolfi and Renzulli 
2012) on our samples gave temperature above $720^{\circ} \mathrm{C}$ and the crystals record a frequent change from growth to resorption, we argue that the crystals were never below the diffusion threshold for any significant amount of time. Therefore, our diffusion modeling at these temperatures should record similar residence time scales of tens to hundreds of thousands of years for U-Th isotope geochronology. Indeed, a U/Th mineral isochron on Taapaca dacite TAP-02-03, the host of several sanidines studied here, gave a U-series mineral age of $171 \pm 26$ (Kiebala, 2008), as mentioned earlier. Because the mineral assemblage in the host dacite must be younger, this is a minimum age for the sanidine megacrysts, consistent with the diffusion model results.

Results from R-MELTS modeling which predict the rheological lock-up and solidus for the rhyodacite at $750-770{ }^{\circ} \mathrm{C}$ and at $<700{ }^{\circ} \mathrm{C}$, clearly suggest that the crystals were stored at temperatures slightly above the magma solidus, but as a rigid crystal-rich mush (with $>50 \%$ crystals) for most $(>98 \%)$ of their storage time. This would make the Taapaca reservoir a clear case for "cold storage" at temperatures $>720{ }^{\circ} \mathrm{C}$ and 1-3 kbar pressure.

Storage is affected by many intermittent heating events, which raised the temperature above the sanidine liquidus $\left(\sim 735-760{ }^{\circ} \mathrm{C}\right)$. These heating events are not, as discussed earlier, related to compositional mixing and hybridization of the resident crystal mush by a more mafic recharge magma. These events also did not result in mobilization and eruption but served to keep the entire reservoir thermally "alive" slightly above the bulk solidus for a long time (Gelman et al. 2013; Huber et al. 2012). Quartz, which should be crystallizing next to sanidine close to the solidus, however, was never found as inclusion in sanidine megacrysts and only rarely occur as partly dissolved remnant in the host hybrid dacite. Since quartz apparently dissolves more rapidly when the host melt is heated during thermal cycling, the intermittent heating events also explain the absence of quartz inclusions in sanidine. 


\subsubsection{What triggered the eruption?}

We can safely assume that repeated heating events are related to recharge of more mafic andesitic magma into the resident rhyodacitic crystal-melt mush. These recharges did not cause compositional changes of the silicic melt in which sanidine crystals were growing and dissolving. Apparently, many recharges occurred without triggering an eruption. Similar observations in andesitic systems are consistent with these observations: up to ten resorption events can be recorded during the growth of even small plagioclase phenocrysts until the final recharge triggers the eruption (Ruprecht and Wörner 2007). The erupted dacite and host to the sanidine megacrysts is a hybrid between a rhyodacite and mafic andesite magmas as shown by abundant mafic enclaves and bimodal populations of amphibole phenocryst compositions and thus, bimodal temperature and pressure (Blum-Oeste and Wörner 2016; this study). After many earlier magma mixing events, possibly farther away or weaker, this last recharge apparently was sufficiently strong and/or sufficiently close to the particular portion of residing crystal mush that it eventually did mix and mobilized the mush into an eruptible magma that rose to the surface. Other similar recharge events recorded in the sanidine, as interpreted earlier, may have mobilized other portions of the reservoir at earlier times to result in older dacite dome eruptions.

However, the relative uniformity of dacite compositions and their crystal content throughout the history of Taapaca volcano reflects a critical threshold of recharge flux into the crystal mush that is sufficiently strong to remobilize. Weaker recharge events may not trigger an eruption but contribute to the overall heat budget of the system to keep it "alive". Once the critical "break-through" threshold has been overcome, mixing occurs, and the hybrid dacite is always similar in composition which then erupts and carries large sanidine crystals that survived the heating of the mush. 


\subsection{Summary and conclusion:}

Based on all the above interpretations, we present a generalized model (Fig 15) for the origin and eruption of sanidine megacrysts at Taapaca volcano. We take the Ba-content variation of an exemplary sanidine as proxy of the thermal variation in the rhyodacite crystal mush with time (Fig 11). The model starts at the onset of crystallization from the parent rhyo-dacite and continues for up to $499 \mathrm{ky}$ of crystal storage until the respective eruption. After core formation, the overall temperature starts to decrease for a period of up to 490 years. This comprises of major part of the duration of storage (up to 98\%) and is affected by smaller intermittent heating events. This period represents long-term evolution of the system at near eutectic composition and a depth of $4-10 \mathrm{~km}$ (based on barometric results). Different temperatures and pressures from thermo-barometry, different total diffusion times, and the non-correlation between residence time and crystal size suggest that crystals grew in different parts of the reservoir, generally undergoing a similar growth history but on different time scale and at different times. The overall cooling period finally ends about 3000-11,000 years prior to eruption when the system slowly starts to heat up with more frequent recharge events (at intervals of 1000-10,000 years). A pre-eruptive stage occurred from 400 to 3000 years before the eruption when temperatures rose further and the recharge frequency significantly increased. The fine-scale high frequency zonation at the outermost rims of the crystals mark the arrival of the major basaltic andesite recharge and the beginning of its mixing and mingling with the rhyodacite. This final eruption-triggering recharge eventually was sufficiently strong and "successful" resulting in the mobilization and eruption of the crystals by the recently formed hybrid dacite. This final stage, therefore, must have happened after the "heat-up phase" (400-3000 years), i.e. within the last few centuries or even decades before eruption. A similar sequence of events was repeated for each eruption where some parts of the mush reservoir containing the crystals erupted while other parts remained to be erupted at a later stage.

The overall storage model for Taapaca volcano suggests that even small silicic volcanoes store material above solidus at shallow depth for hundreds of thousands of years. This reinstates the idea of long-term storage as a crystal-rich mush or the "cold storage", but the temperature can be above or below solidus depending on the frequency and extent of recharges. Recharges of some regimes can heat up other regimes without chemically affecting them but keeping them thermally active. Because of this, the crystals undergo a very complicated and long thermal history with frequent resorption and growth cycles. The 
duration of hundreds to thousands of years between mobilization and eruption suggests a rather "low and slow" mobilization of magma (Kaiser et al. 2017) in contrast to rapid mobilization (Druitt et al. 2012, Cooper and Kent 2014).

In terms of methodology, in this study, the non-isothermal diffusion modeling proves to be a very efficient tool that gives relatively fine-scaled information on changing frequency and extent of recharges, and remobilization time-scales. With proper constraints on temperature variation, this can be a very useful tool for modeling other volcanic systems.

Acknowledgments: This study is a part of the doctoral research project funded by a scholarship from Deutscher Akademischer Austauschdienst (DAAD) to S. S. Rout. We thank A. Kronz for his support during electron microprobe analysis. We also thank W. Wegner for the support in data acquisition.

\subsection{References}

Albert H, Costa F, Martí J (2016) Years to weeks of seismic unrest and magmatic intrusions precede monogenetic eruptions. Geology 44 (3):211-214.

Alfano F, Bonadonna C, Volentik ACM et al. (2011) Tephra stratigraphy and eruptive volume of the May, 2008, Chaitén eruption, Chile. Bull Volcanol 73: 613.

Allan ASR, Barker SJ, Millet MA, Morgan DJ, Rooyakkers SM, Schipper CI, Wilson CJN (2017) A cascade of magmatic events during the assembly and eruption of a super-sized magma body. Contributions to Mineralogy and Petrology 172:49

Allmendinger RW, Jordan TE, Kay SM, Isacks B (1997) The evolution of the Altiplano-Puna plateau of the Central Andes. Annual Reviews of Earth and Planetary Sciences 25:139-174.

Annen C, Pichavant M, Bachmann O, Burgisser A (2008) Conditions for the growth of a long-lived shallow crustal magma chamber below Mount Pelee volcano (Martinique, Lesser Antilles Arc). J Geophys Res 113, B07209, http://dx.doi.org/10.1029/2007JB005049

Bachmann O, Bergantz GW (2008) Rhyolites and their source mushes across tectonic settings. J Petrol 49:2277-2285.

Banaszak M (2007) Kristallisationsbedingungen und Barium-Zonierung von Sanidinen in Magmen des Taapaca Vulkans, Nord Chile. Diplomarbeit. Universität göttingen, Germany

Banaszak M (2014) Differentiation regimes in the Central Andean magma systems: case studies of Taapaca and Parinacota volcanoes, Northern Chile, PhD thesis, Georg-August Universität, Göttingen.

Barboni M, Boehnke P, Schmitt AK et al (2016) Warm storage for arc magmas. Proc. Natl. Acad. Sci. U.S.A. 113:13959-13964. 
Blum-Oeste M, Wörner G (2016) Central Andean magmatism can be constrained by three ubiquitous end-members. Terra Nova 28:434-440.

Bourdon B, Zindler A, Wörner G (1994) Evolution of the Laacher See magma chamber; evidence from SIMS and TIMS measurements of U-Th disequilibria in minerals and glasses. Earth Planet Sci Lett 126:75-90.

Cahill T, Isacks BL (1992) Seismicity and shape of the subducted Nazca plate. Journal of Geophysical Research Letters 97:17503-17529.

Chakraborty S (2008) Diffusion in solid silicates: a tool to track timescales of processes comes of age. Annu Rev Earth Planet Sci 36:153-190.

Chakraborty S, Ganguly J (1991) Compositional Zoning and Cation Diffusion in Garnets. In: Ganguly, J., Editor, 1991. Diffusion, Atomic Ordering and Mass Transport, SpringerVerlag, pp. $120-175$.

Chamberlain KJ, Morgan DJ, Wilson CJN (2014) Timescales of mixing and mobilisation in the Bishop Tuff magma body: perspectives from diffusion chronometry. Contrib Mineral Petrol 167:1034

Cherniak DJ (2002) Ba diffusion in feldspar. Geochimica et Cosmochimica Acta 66:1641-1650.

Cherniak DJ (2010) Cation diffusion in feldspars. In Y. Zhang, and D.J. Cherniak, Eds, Diffusion in Minerals and Melts, 72, p. 691-733. Reviews in Mineralogy and Geochemistry, Mineralogical Society of America and Geochemical Society.

Clavero JE (2002) Evolution of Parinacota volcano and Taapaca Volcanic Complex, Central Andes of Northern Chile. PhD thesis Univ. of Bristol (unpublished): 222pp.

Clavero JE, Sparks RSJ, Polanco E, Pringle MS (2004) Evolution of Parinacota volcano, Central Andes, Northern Chile: Revista Geologica de Chile 31: 17-347.

Clavero JE, Sparks RSJ, Pringle MS, Polanco E, Gardeweg MC (2004) Evolution and volcanic hazards of Taapaca Volcanic Complex, central Andes of northern Chile. Journal of Geological Society $161,603-618$.

Condomines M, Hemond C, Allegre CJ (1988) U-Th-Ra radioactive disequilibria and magmatic processes. Earth Planet Sci Lett 90:243-262

Cooper KM (2019) Time scales and temperatures of crystal storage in magma reservoirs: implications for magma reservoir dynamics. Philosophical Transactions of the Royal Society A: Mathematical, Physical and Engineering Sciences 377:2139. doi:doi:10.1098/rsta.2018.0009

Cooper KM, Kent AJR (2014) Rapid remobilization of magmatic crystals kept in cold storage. Nature 506:480-483.

Cooper KM, Reid MR, Murrell MT, Clague DA (2001) Crystal and magma residence times at Kilauea Volcano, Hawaii:230Th-226Ra dating of the 1955 east rift eruption. Earth Planet Sci Lett 184:703-718. 
Costa F, Chakraborty S (2004) Decadal time gaps between mafic intrusion and silicic eruption obtained from chemical zoning patterns in olivine. Earth Planet Sci Lett 227:517-530.

Costa F, Chakraborty S, Dohmen R (2003) Diffusion coupling between trace and major elements and a model for calculation of magma residence times using plagioclase. Geochim Cosmochim Acta 67:2189-2200

Costa F, Dohmen R, Chakraborty S (2008) Timescales of magmatic processes from modeling the zoning patterns of crystals. In: Putirka KD, Tepley III FJ (eds) Minerals, Inclusions and Volcanic Processes. RiMG 69, Mineralogical Society of America, Chantilly, VA, USA, pp $545-594$.

Costa F, Dungan M (2005) Short time scales of magmatic assimilation from diffusion modeling of multiple elements in olivine. Geology 33:837-840

Costa F, Morgan D (2010) Time constraints from chemical equilibration in magmatic crystals. In: Dosseto A, Turner SP, Van Orman JA (eds) Timescales of magmatic processes: from core to atmosphere. John Wiley \& Sons, Ltd, Chichester, UK. doi: 10.1002/9781444328509.ch7

Crank J (1975) The Mathematics of Diffusion. Clarendon-Oxford, London.

Druitt TH, Costa F, Deloule E, Dungan M, Scaillet B (2012). Decadal to monthly timescales of magma transfer and reservoir growth at a caldera volcano. Nature 482:77-80

Ellis BS, Bachmann O, Wolff JA (2014) Cumulate fragments in silicic ignimbrites: The case of the Snake River Plain. Geology 42:431-434.

Ginibre C, Wörner G, Kronz A (2002) Minor- and trace-element zoning in plagioclase: implications for magma chamber processes at Parinacota volcano, northern Chile. Contributions to Mineralogy and Petrology 143:300-315.

Ginibre C, Wörner G, Kronz A (2004) Structure and Dynamics of the Laacher See Magma Chamber (Eifel, Germany) from Major and Trace Element Zoning in Sanidine: a Cathodoluminescence and Electron Microprobe Study. Journal of Petrology, 45:2197-2223.

Ginibre C, Wörner G, Kronz A (2007) Crystal zoning as an archive for magmatic evolution. Elements 3:261-266.

Glazner AF, Boudreau A (2011) Metamorphism of thought about igneous rock textures. Int Geol Rev 53:327-329. https ://doi.org/10.1080/00206 814.2010.49616

Gualda GAR, Ghiorso MS, Lemons RV, Carley TL (2012) Rhyolite-MELTS: A modified calibration of MELTS optimized for silica-rich, fluid-bearing magmatic systems. Journal of Petrology 53:875-890.

Haase CS, Chadam J, Feinn D, Ortoleva P (1980) Oscillatory Zoning in Plagioclase Feldspar. Science 209 (4453):272-274.

Hawkesworth CJ, Blake S, Evans P et al (2000) Time scales of crystal fractionation in magma chambers-integrating physical, isotopic and geochemical perspectives. J Petrol 41:991-1006 
Hawkesworth C, George R, Turner S, zellmer G (2004) Time scales of magmatic processes. Earth Planet Sci Lett 218:1-16.

Higgins MD (1999) Origin of megacryst in granitoids by textural coarsening: a crystal size distribution (CSD) study of microcline in the Cathedral Peak Granodiorite, Sierra Nevada, California. In: Castro A, Fernández C, Vigneresse JL (eds) Understanding granites: Integrating new and classical techniques.

Hofmeister AM, Sehlke A, Avard G et al. (2016) Transport Properties of Glassy and Molten Lavas as a Function of Temperature and Composition. Journal of Volcanology and Geothermal Research 327: 330-348.

Holland T, Blundy J (1994) Non-ideal interactions in calcic amphiboles and their bearing on amphibole- plagioclase thermometry. Contributions to Mineralogy and Petrology 116:433447.

Holness MB, Clemens JD, Vernon RH (2018) How deceptive are microstructures in granitic rocks? Answers from integrated physical theory, phase equilibrium, and direct observations. Contrib Mineral Petrol 173:62.

Hora JM, Singer BS, Wörner G (2007). Volcano evolution and eruptive flux on the thick crust of the Andean Central Volcanic Zone; 40Ar/39Ar constraints from Volcán Parinacota, Chile. Geological Society of America Bulletin 119:343-362.

Hora JM, Singer BS, Wörner G, Beard BL, Jicha BR, Johnson CM (2009). Shallow and deep crustal control on differentiation of calc-alkaline and tholeiitic magma. Earth and Planetary Science Letters 285:75-86.

Huber C, Bachmann O, Dufek J (2012) Crystal-poor versus crystal-rich ignimbrites: a competition between stirring and reactivation. Geology 40:115-118.

Iovine RS, Fedele L, Mazzeo FC et al (2017) Timescales of magmatic processes prior to the $\sim 4.7 \mathrm{ka}$ Agnano-Monte Spina eruption (Campi Flegrei caldera, Southern Italy) based on diffusion chronometry from sanidine phenocrysts. Bull Volcanol 79:18.

Isacks BL (1988) Uplift of the Central Andean plateau and bending of the Bolivian orocline. Journal of Geophysical Research 93 (B4) 3211 - 3231.

Jackson MD, Blundy J, Sparks RSJ (2018) Chemical differentiation, cold storage and remobilization of magma in the Earth's crust. Nature 564:405-409.

James DE (1971). Andean crustal and upper mantle structure. Journal of Geophysical Research 76:3246-3271.

Johnson BR, Glazner AF (2010) Formation of K-feldspar megacrysts in granodioritic plutons by thermal cycling and late-stage textural coarsening. Contrib Mineral Petrol 159: 599. https://doi.org/10.1007/s00410-009-0444-z

Johnson MC, Rutherford MJ (1989) Experimental calibration of the aluminum-in-hornblende geobarometer with application to Long Valley caldera (California). Geology 17:837-841. 
Kahl M, Chakraborty S, Costa F, Pompilio M, Liuzzo M, Viccaro M (2013). Compositionally zoned crystals and real-time degassing data reveal changes in magma transfer dynamics during the 2006 summit eruptive episodes of Mt. Etna. Bulletin of Volcanology 75: 692. https://doi.org/10.1007/s00445-013-0692-7

Kahl M, Chakraborty S, Pompilio M, Costa F (2015). Constraints on the Nature and Evolution of the Magma Plumbing System of Mt. Etna Volcano (1991-2008) from a Combined Thermodynamic and Kinetic Modelling of the Compositional Record of Minerals. Journal of Petrology 56: 2025-2068.

Kaiser JF, de Silva S, Schmitt AK, Economos R, Sunagua M (2017) Million-year melt-presence in monotonous intermediate magma for a volcanic-plutonic assemblage in the Central Andes: contrasting histories of crystal-rich and crystal poor super-sized silicic magmas. Earth Planet. Sci. Lett. 457:73-86.

Kiebala A (2008) Magmatic processes by U-Th disequilibrium method - Comaprison of two Andean magma systems: El Misti Volcano (South Peru) versus Taapaca volcanic Complex (North Chile). PhD-thesis University Göttingen: 1-93.

Kohlbach I, Lohnert E (1999) Geological map of Taapaca Volcano and adjacent areas, North Chile. Diploma mapping thesis Univ. Göttingen,(unpublished): 70pp.

Loewy SL, Connelly JN, Dalziel IWD (2004) An Orphaned Basement Block: The Arequipa- Antofalla Basement of the Central Andean margin of South America. Geological Society of America Bulletin 116:171-187.

Lohnert E (1999) Chemical variation of s sanidine megacryste and its implication on the pre-eruptive evolution of the Taapaca volcano in North Chile: Electron microprobe and Sr- isotope studies. Diploma thesis Univ. Göttingen,(unpublished): 70pp

McLeod CL, Davidson JP, Nowell GM, de Silva SL, Schmitt AK (2013) Characterizing the continental basement of the Central Andes: Constraints from Bolivian crustal xenoliths. GSA Bulletin 125:985-997.

Morgan DJ, Blake S (2006) Magmatic residence times of zoned phenocrysts: introduction and application of the binary element diffusion modelling (BEDM) technique. Contrib Mineral Petrol 151:58-70.

Morgan DJ, Blake S, Rogers NW et al (2004) Time scales of crystal residence and magma chamber volumes from modelling of diffusion profiles in phenocrysts: Vesuvius 1944. Earth Planet Sci Lett 222:933-946.

Mutch EJF, Blundy JD, Tattitch BC, Cooper FJ, Brooker RA (2016) An experimental study of amphibole stability in low-pressure granitic magmas and a revised Al-in-hornblende geobarometer. Contributions to Mineralogy and Petrology 171:85. 
Pankhurst MJ, Morgan DJ, Thordarson T, Loughlin SC (2018) Magmatic crystal records in time, space, and process, causatively linked with volcanic unrest. Earth Planet Sci Lett 493:231241.

Luigi Passarelli, Emily E. Brodsky (2012) The correlation between run-up and repose times of volcanic eruptions, Geophysical Journal International 188:1025-1045

Pearce TH, Kolisnik AM (1990) Observations of plagioclase zoning using interference imaging. Earth-Science Reviews 29:9-26.

Petrone CM, Bugatti G, Braschi E, Tommasini S (2016) Pre-eruptive magmatic processes re timed using a non-isothermal approach to magma chamber dynamics. Nature communications $7: 12946$.

Reid MR (2008) How long does it take to supersize an eruption? Elements 4:23-28.

Ridolfi F, Renzulli A, Puerini M (2010) Stability and chemical equilibrium of amphibole in calcalkaline magmas: an overview, new thermobarometric formulations and application to subduction-related volcanoes. Contributions to Mineralogy and Petrology 160:45-66.

Ridolfi F, Renzulli A (2012) Calcic amphiboles in calc-alkaline and alkaline magmas: thermobarometric and chemometric empirical equations valid up to $1,130 \mathrm{C}$ and $2.2 \mathrm{GPa}$. Contrib Mineral Petrol 163:877-895

Romine WL, Whittington AG, Nabelek PI et al. (2012) Thermal diffusivity of rhyolitic glasses and melts: effects of temperature, crystals and dissolved water. Bull Volcanol 74: 2273.

Rout SS, Schmidt BC, Wörner G (2019) Constraints on non-isothermal diffusion modeling: an experimental analysis and error assessment using halogen diffusion in melts. American Mineralogist. In press

Rubin A, Cooper KM, Leever M, Wimpenny J, Deering C, Rooney T, Gravley D, Yin Q-z (2016) Changes in magma storage conditions following caldera collapse at Okataina Volcanic Center, New Zealand. Contributions to Mineralogy and Petrology 171(4):1-18 doi:10.1007/s00410015-1216-6

Rubin AE, Cooper KM, Till CB et al (2017) Rapid cooling and cold storage in a silicic magma reservoir recorded in individual crystals. Science 356:1154-1156.

Ruprecht P, Wörner G (2007) Variable regimes in magma systems documented in plagioclase zoning patterns: El Misti stratovolcano and Andagua monogenetic cones (S. Peru). J Volcanol Geoth Res 165: 142-162

Samoza R (1998) Updated Nazca (Farallon)-South America relative motions during the last $40 \mathrm{My}$ : implications for mountain building in the central Andean region. Journal of South American Earth Science 11:211-215.

Saubin E, Tuffen H, Gurioli L et al. (2016) Conduit Dynamics in Transitional Rhyolitic Activity Recorded by Tuffisite Vein Textures from the 2008-2009 Chaitén Eruption. Front. Earth Sci. 4:59. 
Scheuber E, Bogdanic T, Jensen A, Reutter K-J (1994) Tectonic development of the North Chilean Andes in relation to plate convergence and magmatism since the Jurassic. In: Reutter, K.-J., Scheuber, E. \& Wigger, P. (Herausgeber): Tectonics of the Southern Central Andes, S. 121139 , Springer.

Scheuber E, Giese P (1999) Architecture of the Central Andes a compilation of geoscientific data along a transect at $21^{\circ} \mathrm{S}$. Journal of South American Earth Sciences 12:103-107.

Schmitt AK (2011) Uranium series accessory crystal dating of magmatic processes. Annu Rev Earth Planet Sci 39:321-349.

Shore M, Fowler AD (1996) Oscillatory zoning in minerals: a common phenomenon. The Canadian Mineralogist 34:1111-1126.

Singer BS, Dungan MA, Layne GD (1995) Textures and Sr, Ba, Mg, Fe, K, and Ti compositional profiles in volcanic plagioclase: Clues to the dynamics of calcalkaline magma chambers. American Mineralogist 80:776 - 798.

Slaby E, Götze J, Wörner G, Simon K, Wrzallik R, Smigielski M (2008) K-feldspar phenocrysts in microgranular magmatic enclaves: A cathodoluminescence and geochemical studies on crystal growth as a marker of magma mingling dynamics. Lithos 105: 85-97

Storm S, Schmitt AK, Shane P, Lindsay JM (2014) Zircon trace element chemistry at submicrometer resolution for Tarawera volcano, New Zealand, and implications for rhyolite magma evolution. Contrib. Mineral. Petrol. 167:1000

Tassara A, Götze HJ, Schmidt S, Hackney R (2006) Three-dimensional density model of the Nazca plate and the Andean continental margin. Journal of Geophysical Research: Solid Earth 111:1978-2012.

Thorpe RS, Francis PW, Hammill M, Baker MCW (1982) The Andes. In: Thorpe RS (ed.) Andesites: Orogenic Andesites and related Rocks. Wiley and Sons, New York: 187-205.

Vernon RH (1986) K-feldspar megacrysts in granites - Phenocrysts, not porphyroblasts. EarthScience Reviews 23(1):1-63. DOI: 10.1016/0012-8252(86)90003-6.

Wegner, W. (2004). Growth History of Sanidine Crystals in Taapaca Dacites. Diploma thesis. GeorgAugust Universität Göttingen, Germany.

Wilson PR (1970) A solution to the diffusion equation for non isothermal diffusion. Solid-state electronics 13:1311-1313.

Wörner G (2018) Continental arc magmatism on thick, old and hot crust: Geology, volcanology and petrology along a w-e transect from Arica to Volcan Taapaca and Parinacota. Field Guide SOTA 7, Sept. 9-15, 2018.

Wörner G, Hammerschmidt K, Henjes-Kunst F, Lezaun J, Wilke H (2000) Geochronology (40Ar/39Ar, K-Ar and He-exposure ages) of Cenozoic magmatic rocks from northern Chile $\left(18-22^{\circ} \mathrm{S}\right)$ : implications for magmatism and tectonic evolution of the central Andes. Revista Geológica de Chile 27 (2):205-240. 
Wörner G, Harmon R, Davidson J, Moorbath S, Turner D, Mc Millan N, Nyc C, López L (1988) The Nevados de Payachata volcanic region (18S/69W, N. Chile). 1. Geological, geochemical and isotopic observations. Bulletin of Volcanology 50: 287-303.

Wörner G, Mamani M, Blum-Oeste (2018) Magmatism in the Central Andes. Elements 14(4):237-244

Yuan X, Sobolev SV, Kind R (2002) Moho topography in the Central Andes and its geodynamic implications. Earth and Planetary Science Letters 199:389-402.

Zandt G, Velasco AA, Beck S (1994) Composition and thickness of the southern Altiplano crust, Bolivia. Geology 22:1003-1006.

Zellmer GF, Blake S, Vance D, Hawkesworth C, Turner S (1999) Short plagioclase residence times at two island arc volcanoes (Kameni islands, Santorini, and Soufriere, St. Vincent) determined by Sr diffusion systematics. Contrib Mineral Petrol 136:345-357.

Zellmer GF, Clavero JE (2006) Using trace element correlation patterns to decipher a sanidine crystal growth chronology: An example from Taapaca volcano, Central Andes. J Volcanol Geotherm Res 156:291-301.

Zellmer G, Turner S, Hawkesworth C (2000) Timescales of destructive plate margin magmatism: new insights from Santorini, Aegean volcanic arc. Earth Planet Sci Lett 174:265-281.

Zhang Y, Ni H, Chen Y (2010) Diffusion data in silicate melts. In Y. Zhang, and D.J. Cherniak, Eds, Diffusion in Minerals and Melts, 72, p. 311-408. Reviews in Mineralogy and Geochemistry, Mineralogical Society of America and Geochemical Society. 


\section{Chapter 6: Conclusion}

\subsection{Introduction:}

The results of this PhD project help towards understanding of the long (up to thousands to hundreds of thousands of years) storage history of magmas that feed silicic volcanoes. This work is the first study to constrain the thermal evolution and recharge history of the Laacher See volcano which is one of the largest explosive Quaternary centers in Central Europe and has spread its tephra all across Northern Central Europe 12,900 years BP (Baales et al. 2002). The recent signs of magmatic activity underneath the Laacher volcano (Goepel et al. 2015; Hensch et al. 2019), which has huge hazard potential if it becomes active any time in the future (Leder et al. 2017), make this study even more timely and essential. Similarly, for Taapaca volcano, which is a hazard to nearby Putre area and in case of an eruption, is expected to have impacts reaching as far as Bolivia, the results from this study serve as a tool to understand the innerworkings of a system that has an eruption history of $>1.5 \mathrm{My}$ (Clavero et al. 2004). It is extremely important to know the nature and time-scales of eruption triggering events in such long-lived yet potentially dangerous volcanoes to interprete realtime monitoring data and for risk assessment.

The cumulative results of this project also contribute towards a more realistic model for (1) magma reservoir which is highly debated between the "cold" and "warm" storage models (Cooper and Kent 2014; Annen et al., 2008; Barboni et al. 2016; Rubin et al. 2017; Kaiser et al. 2017) and pre-eruptive reactivation time-scales which is debated between "fast" and "slow" reactivation (Bachmann and Bergantz 2008; Cooper and Kent 2014; Barboni et al. 2016; Rubin et al. 2017; Kaiser et al. 2017). In terms of methodology, this study also aims towards contributing to volcanological research in terms of applications of multi-faceted diffusion modeling (uphill diffusion and non-isothermal diffusion). 


\subsection{Summary of findings and conclusions:}

The key findings are summarized along with the overall conclusions in the sub-sections below.

\section{Pre-eruptive history of Laacher See volcano:}

K-Na-interdiffusin modeling and Ba-diffusion modeling was applied to different eruption products from Laacher See to constrain the thermal and temporal evolution of the magma system. The Laacher See magma system which shows magma and crystal storage timescales of 20-24 ky before eruption, is apparently a combination of both warm and cold storage, each one applicable to a specific part of the reservoir. The crystalline carapace that consitiutes the carbonatitic-syenite at the top and the cumulates at the reservoir walls (Schmitt et al. 2010; Ginibre et al. 2004), undergoes fast cooling to sub-solidus temperatures and is stored at those conditions until eruption. The liquid-dominated phonolitic core, on the other hand, remains at high temperatures of $>750{ }^{\circ} \mathrm{C}$ with continuation of crystallization and growth. This high temperature of the core, which is also the main body of the reservoir (Wörner and Schmincke $1984 a, b)$ is maintained by regular heat transferring recharge events every 1500-3000 years. This regular transfer of heat induced regular dissolution and growth cycles throughout the 20-24 ky long history. Although some of the heating events were strong enough to dissolve most of the old crystals, a few still survived to get erupted 12.9 BP. After all these recharges that failed to initiate eruption, the basanite recharge which occurred maximum a few years before eruption, was successful in remobilizing the reservoir and cause eruption. The limited time between the recharge and the eruption ensured limited heating and very limited overgrowth. The last and final destabilization, which broke the carapace, included the bits and pieces into the phonolite to be erupted almost immediately, happened a maximum of 2-7 weeks before the eruption. This suggests that although the storage was thousands of years long, the proceeses leading up to the gigantic eruption were rather fast, operating at speeds of weeks to a few years. 


\section{Pre-eruptive history of Taapaca volcano}

The non-isothermal Ba-diffusion model aided by intra-crystal thermometry and R-MELTS modeling was applied to cm-scale sanidine megacrysts from Taapaca volcano to constrain the pre-eruptive history and develop a model for the thermal evolution of the reservoir. The presented model suggests that the sanidine megacrysts are stored in the host magma for up to $499 \mathrm{ky}$ until the respective eruption. They spend majority of their storage time in overall long cooling periods that is affected by only smaller intermittent heating events happening at intervals of tens of thousands of years. These heating events cause cycles of alternating dissolution and long periods of growth providing the conditions for the megacrystic growth. This period ends about 3000-11,000 years before eruption when the system starts to heat up with recharges of higher frequency (at intervals of 1000-10,000 years) and greater strength. A pre-eruptive stage with high temperature and even higher recharge frequency occurred at 400 to 3000 years which was most probably the arrival of the basaltic andesite magma which then mixed and mingled with the rhyodacite to form the dacite which erupted and brought the megacrysts to the surface.

It is interpreted that while the general history remained the same, the crystals grew in different parts of the reservoir and at different points of time. A set of events similar to mentioned above was repeated for each part of the reservoir. The mafic recharge erupted the crystals from one part while the other parts experienced only the thermal effects. This led to all the megacrysts experiencing the similar set of events but separately at different scales (leading to diverse crystal size and residence time) and at different points of time. The storage model of Taapaca volcano is a case of "cold storage" (Cooper and Kent 2014; Rubin et al. 2017), where the crystals are stored as a rigid non-eruptible mush $(>40-60 \%$ crystallinity) at near- or slightly above-solidus temperature. The duration of hundreds to thousands of years of preeruptive remobilization makes it also a case for rather slow remobilization of magma (Kaiser et al. 2017). 


\section{Efficiency of non-isothermal diffusion model:}

Applying the non-isothermal diffusion model to magmatic crystals with multiple diffusion interfaces along resorption interfaces is closer to the actual process compared to isothermal modeling, and should result in more realistic diffusion and residence time estimates for complexly zoned crystals. The model was tested experimentally using halogen $(\mathrm{Cl}$ and $\mathrm{F})$ diffusion in phonolitic melt. The results suggest that the model works for practical conditions and efficiently estimates time-scales of diffusion during crystal growth at different temperatures. However, the potential pitfalls due to accumulating effects of errors due to insufficiently constrained temperature histories must be realized. Attempting to overcome these limitations should result in more precise estimation of the total diffusion time-scale, crystal residence times and the history of magmatic process prior to eruption. For this purpose, the alternate curve parameter method is proposed in this study, which is simpler in use and yields significantly less error. However, uncertainties in curve fitting and diffusivity parameters still contribute to the total error which can still be high and therefore, the model needs to be applied carefully. From our experiments, it is also clear that the order of magnitude of diffusion coefficient and the degree of change in condition does not affect the outcome of the model.

\section{Broader conclusions:}

The findings from samples of both Laacher See and Taapaca reinforce idea of crystals being stored for tens to hundreds of thousands of years within silicic reservoirs (Morgan and Blake 2006; Reid 2008; Cooper and Kent 2014) before being remobilized to get erupted. The results from Taapaca volcano suggest that even small volcanoes can store material for hundreds of thousands of years. The study suggests that no single storage model can be universally applicable to any volcano. Rather one volcano (like Laacher See) can even accommodate both the "warm" and "cold" storage models applicable separately to different parts of the reservoir. Thus, contrasting magma storage models can be reconcilable provided reservoirs are studied as physically segmented structure with robust yet different thermal and temporal constraints on each of the segment. The results also suggest that volcanoes that are regularly cycled by recharges and heatings, might not always need a very strong mechanical and/or thermal trigger to erupt. 
In terms of methodology, diffusion modeling proves to be an efficient and diverse tool to constrain the thermal and temporal history of magma systems. In combination with other aspects of geochemistry/volcanology like thermo-barometry and/or absolute dating, it can provide robust constraints on magmatic history. The increased focus on the methods of geothermo- barometry and absolute dating in magmatic systems (e.g. Putirka 2008; Reid 2008; Ridolfi and Renzulli 2012; Schmitt 2011; Rubin et al. 2016; Mutch et al. 2016; Sun and Liang 2017; Reverdatto et al. 2019) should extend the use diffusion modeling to more volcanic systems in future studies.

\subsection{Outlook:}

The study suggests that both Taapaca and Laacher See volcano have undergone similar preeruptive history, but at very different temporal scales e.g. in terms of range of storage time, recharge frequency, pre-eruptive activation etc. Thus, the obvious question arises that what really controls these changes? To answer these questions, a more detailed study of the plumbing system and role of the recharges is required. This can possibly be achieved through a neat combination of several state-of-the-art techniques, for example careful diffusion and thermodynamic modeling, systems analysis (Kahl et al. 2015) and physical modeling.

The diffusion modeling, especially, is being developed and used significantly as a major tool in volcanology in the past decade (Kahl et al. 2013; Chamberlain et al. 2014; Iovine et al. 2017; Ackerson et al. 2018 and many others). This PhD project adds to this effort by exploring multiple aspects of diffusion modeling. With further developments in the methodology and proper constraints on intensive parameters it can prove to be a method that puts relatively much higher resolution temporal constraints compared to its counterpart direct dating of crystals using short-lived U-series isotopes.

Lastly, the results in this project take a few steps forward towards developing realistic models for large silicic systems, which are extremely vital for active volcanic regions especially large silicic volcanoes e.g. Rotoiti and Oruanui (New Zealand), Yellowstone and long valley (USA), Altiplano-Puna (Central Andes) and Toba (Indonesia). Such models are extremely important to put real-time observations of volcanoes into context and for efficient hazard management. 


\subsection{References:}

Ackerson MR, Mysen BO, Tailby ND, Watson EB (2018) Low-temperature crystallization of granites and the implications for crustal magmatism. Nature 559:94-97.

Annen C, Pichavant M, Bachmann O, Burgisser A (2008) Conditions for the growth of a long-lived shallow crustal magma chamber below Mount Pelee volcano (Martinique, Lesser Antilles Arc). J Geophys Res 113, B07209, http://dx.doi.org/10.1029/2007JB005049

Baales M, Jöris O, Street M et al (2002) Impact of the late glacial eruption of the Laacher See volcano, Central Rhineland, Germany. Quaternary Research 58:273-288.

Bachmann O, Bergantz GW (2008) Rhyolites and their source mushes across tectonic settings. J Petrol 49:2277-2285.

Barboni M, Boehnke P, Schmitt AK et al (2016) Warm storage for arc magmas. Proc. Natl. Acad. Sci. U.S.A. 113:13959-13964.

Chamberlain KJ, Morgan DJ, Wilson CJN (2014) Timescales of mixing and mobilisation in the Bishop Tuff magma body: perspectives from diffusion chronometry. Contrib Mineral Petrol $167: 1034$

Clavero JE, Sparks RSJ, Pringle MS, Polanco E, Gardeweg MC (2004) Evolution and volcanic hazards of Taapaca Volcanic Complex, central Andes of northern Chile. Journal of Geological Society 161:603-618.

Cooper KM, Kent AJR (2014) Rapid remobilization of magmatic crystals kept in cold storage. Nature 506:480-483

Ginibre C, Wörner G, Kronz A (2004) Structure and Dynamics of the Laacher See Magma Chamber (Eifel, Germany) from Major and Trace Element Zoning in Sanidine: a Cathodoluminescence and Electron Microprobe Study. Journal of Petrology 45:2197-2223

Goepel A, Lonschinski M, Viereck L, Büchel G et al. (2015) Volcano-tectonic structures and CO2 degassing patterns in the Laacher See basin, Germany, Int. J. Earth Sci. 104:1483-1495

Hensch M, Dahm T, Ritter J, Heimann S, Schmidt B, Stange S, Lehmann K (2019) Deep lowfrequency earthquakes reveal ongoing magmatic recharge beneath Laacher See Volcano (Eifel, Germany). Geophysical Journal International 216:2025-2036,

Iovine RS, Fedele L, Mazzeo FC et al (2017) Timescales of magmatic processes prior to the $\sim 4.7 \mathrm{ka}$ Agnano-Monte Spina eruption (Campi Flegrei caldera, Southern Italy) based on diffusion chronometry from sanidine phenocrysts. Bull Volcanol 79:18.

Kahl M, Chakraborty S, Costa F, Pompilio M, Liuzzo M, Viccaro M (2013) Compositionally zoned crystals and real-time degassing data reveal changes in magma transfer dynamics during the 2006 summit eruptive episodes of Mt. Etna. Bulletin of Volcanology 75:692. https://doi.org/10.1007/s00445-013-0692-7

Kahl M, Chakraborty S, Pompilio M, Costa F (2015) Constraints on the Nature and Evolution of the Magma Plumbing System of Mt. Etna Volcano (1991-2008) from a Combined 
Thermodynamic and Kinetic Modelling of the Compositional Record of Minerals. Journal of Petrology 56: 2025-2068, https://doi.org/10.1093/petrology/egv063

Kaiser JF, de Silva S, Schmitt AK, Economos R, Sunagua M (2017) Million-year melt-presence in monotonous intermediate magma for a volcanic-plutonic assemblage in the Central Andes: contrasting histories of crystal-rich and crystal poor super-sized silicic magmas. Earth Planet. Sci. Lett. 457:73-86.

Leder J, Wenzel F, Daniell JE, Gottschämmer E (2017) Loss of residential buildings in the event of a re-awakening of the Laacher See Volcano (Germany), J. Volc. Geotherm. Res. 337:111-123.

Morgan DJ, Blake S (2006) Magmatic residence times of zoned phenocrysts: introduction and application of the binary element diffusion modelling (BEDM) technique. Contrib Mineral Petrol 151:58-70.

Mutch EJF, Blundy JD, Tattitch BC, Cooper FJ, Brooker RA (2016) An experimental study of amphibole stability in low-pressure granitic magmas and a revised Al-in-hornblende geobarometer. Contributions to Mineralogy and Petrology 171:85.

Putirka KD (2008) Thermometers and barometers for volcanic systems. In: Putirka K, Tepley F (eds) Minerals, inclusions and volcanic processes, vol 69, Reviews in mineralogy and geochemistry. Mineralogical Society ofAmerica, Chantilly, VA, USA, pp 61-120

Reid MR (2008) How long does it take to supersize an eruption? Elements 4:23-28.

Reverdatto VV, Likhanov II, Polyansky OP, Sheplev VS, Kolobov VY (2019) Mineral Geothermobarometry. In The Nature and Models of Metamorphism. Springer Geology. Springer, Cham.

Ridolfi F, Renzulli A (2012) Calcic amphiboles in calc-alkaline and alkaline magmas: thermobarometric and chemometric empirical equations valid up to $1,130 \mathrm{C}$ and $2.2 \mathrm{GPa}$. Contrib Mineral Petrol 163:877-895

Rubin A, Cooper KM, Leever M, Wimpenny J, Deering C, Rooney T, Gravley D, Yin Q-z (2016) Changes in magma storage conditions following caldera collapse at Okataina Volcanic Center, New Zealand. Contributions to Mineralogy and Petrology 171(4):1-18 doi:10.1007/s00410015-1216-6

Rubin AE, Cooper KM, Till CB et al (2017) Rapid cooling and cold storage in a silicic magma reservoir recorded in individual crystals. Science 356:1154-1156.

Schmitt AK (2011) Uranium Series Accessory Crystal Dating of Magmatic Processes. Annual Review of Earth and Planetary Sciences 39:321-349

Schmitt AK, Wetzel F, Cooper KM, Zou H, Wörner G (2010) Magmatic longevity of Laacher See volcano (Eifel, Germany) indicated by U-Th dating of intrusive carbonatites. J Petrol 51:10531085.

Sun C, Liang Y (2017) A REE-in-plagioclase-clinopyroxene thermometer for crustal rocks. Contributions to Mineralogy and Petrology 172:24. 
Wörner G, Schmincke HU (1984a) Mineralogical and chemical zonation of the Laacher See tephra sequence (East Eifel, W. Germany). J Petrol 25:805-835.

Wörner G, Schmincke HU (1984b) Petrogenesis of the zoned Laacher SeeTephra. (East Eifel, W. Germany). J Petrol 25:836-851. 


\section{Appendix A}

\section{Curriculum Vitae}

Last name: $\quad$ Rout

First name: $\quad$ Smruti Sourav

Date of birth: $\quad 24.06 .1991$

Place of birth: $\quad$ Dhenkanal, India

\section{$\underline{\text { Education }}$}

Doctorate:

2015-2019

University of Göttingen, Geramny

Superviors: Prof. Dr. Gerhard Wörner; Prof. Dr. Sharon Webb

PhD focused on application of diffusion modeling to magmatic petrology

Masters:

$2012-2014$

Indian Institute of Technology Roorkee, India

Thesis supervisor: Prof. Dr. Sandeep Singh

Master's thesis focused on multi-component diffusion modeling

Bachelors: $\quad$ 2009-2012

Indian Institute of Technology Roorkee, India

Focused on applied geology

\section{Research experience:}

Short-term research projects in University of Toronto, Canada (2012, diffusion modeling) in University of Göttingen, Germany (2013, mass/heat transport) in Indian Institute of Science Bangalore, India (2014-2015, mantle convection modeling) 


\section{Fellowships:}

DAAD doctoral fellowship (2015)

Summer research fellowship from Indian academy of sciences (2012)

MHRD scholarship during bachelor's and master's studies

\section{Field experience:}

Lower Himalayas, Eifel volcanic field (Germany), Goan mining areas (India).

\section{Extra courses during PhD}

MATLAB Recipes for Earth Sciences. Potsdam (2017)

Application of diffusion studies. Bochum (2018)

German (up to B2) 


\section{Appendix B}

\section{Articles published/getting published:}

Rout SS, Wörner G (2018) Zoning and exsolution in alkali feldspars from Laacher See volcano (Western Germany): constraints on temperature history prior to eruption. Contributions to Mineralogy and Petrology 173:95.

Rout SS, Schmidt BC, Wörner G (2019) Constraints on non-isothermal diffusion modeling: an experimental analysis and error assessment using halogen diffusion in melts. American Mineralogist. In press

\section{$\underline{\text { Articles in preparation/to be submitted: }}$}

Rout SS, Wörner G; Constraints on the pre-eruptive magmatic history of Laacher See volcano (Germany): study of different eruption products

Rout SS, Blum-Oeste M, Wörner G; Pre-eruptive history of Taapaca volcano (N. Chile) constrained by non-isothermal diffusion chronometry on sanidine megacrysts.

\section{Major conference abstracts (for oral presentations):}

Rout SS, Wörner G, EGU 2017 (Vienna, Austria)

Rout SS, Schmidt BC, Wörner G, EGU 2018 (Vienna, Austria)

Rout SS, Wörner G, EGU 2019 (Vienna, Austria)

Rout SS and Wörner G, Goldschmidt 2019 (Barcelona, Spain)

DMG meetings 2017 (Bremen), 2018 (Bonn), 2019 (Münster) 


\section{Appendix C}

\section{Supplementary material}

Supplementary materials for each chapter are enclosed electronically in separate folders with individual chapter names.

\section{Chapter 2:}

Supplementary material 1 or ESM 1: More petrographic examples

Supplementary material 2 or ESM 2: Quantitative data from EMP

Supplementary material 3 or ESM 3: BSE images and profiles

Supplementary material 4 or ESM 4: Exsolution bands and profiles

Supplementary material 5 or ESM 5: LA-ICPMS data and estimated partition coefficients

Supplementary material 6 or ESM 6: Additional plots

Supplementary material 7 or ESM 7: Estimation of diffusion threshold

Supplementary material 8 or ESM 8: Modeling of exsolution

Supplementary material 9 or ESM 9: Modeling of Carapace temperature

Chapter 3:

Supplementary material 1 or ESM 1:All BSE images

Supplementary material 2 or ESM 2:All quantitative data (from EMP)

Chapter 4:

Supplementary material 1 or ESM 1: Quantitative data and errors of heating and cooling Supplementary material 2 or ESM 2: Data used for application to natural sample

\section{Chapter 5:}

Supplementary material 1 or ESM 1:Data from EMP and LA-ICPMS

Supplementary material 2 or ESM 2:Thermo-barometric data

Supplementary material 3 or ESM 3:Ba-intensity maps and BSE images

Supplementary material 4 or ESM 4:Parameters for fractional crystallization model

Supplementary material 5 or ESM 5: Intra-crystal individual diffusion times

Supplementary material 6 or ESM 6: Estimation of diffusion threshold 